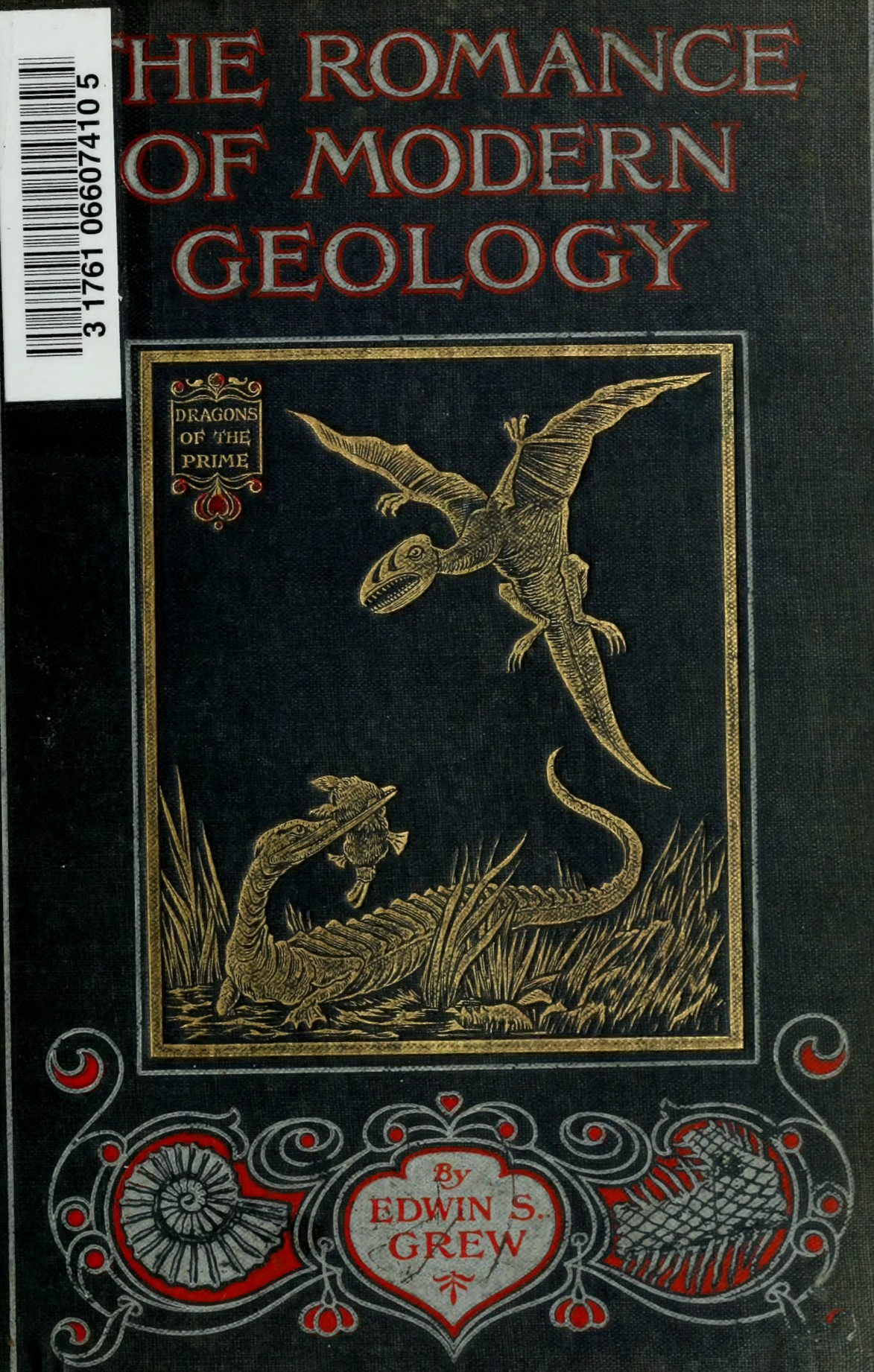




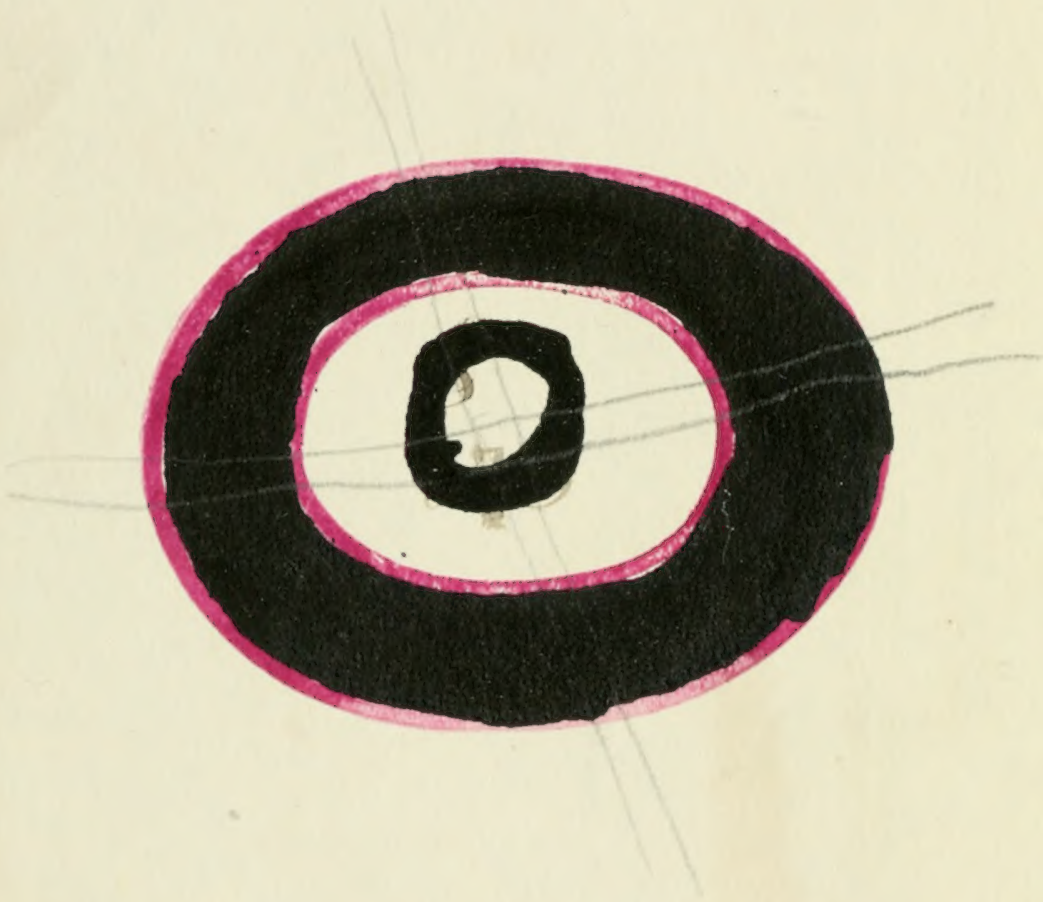




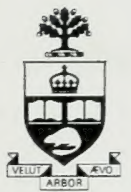

Presented to the

LIBRARIES of the

UNIVERSITY OF TORONTO

by

The Association of

Geoscientists for

International Development

(Canada) 
Digitized by the Internet Archive in 2010 with funding from University of Toronto 
THE ROMANCE OF MODERN GEOLOGY 




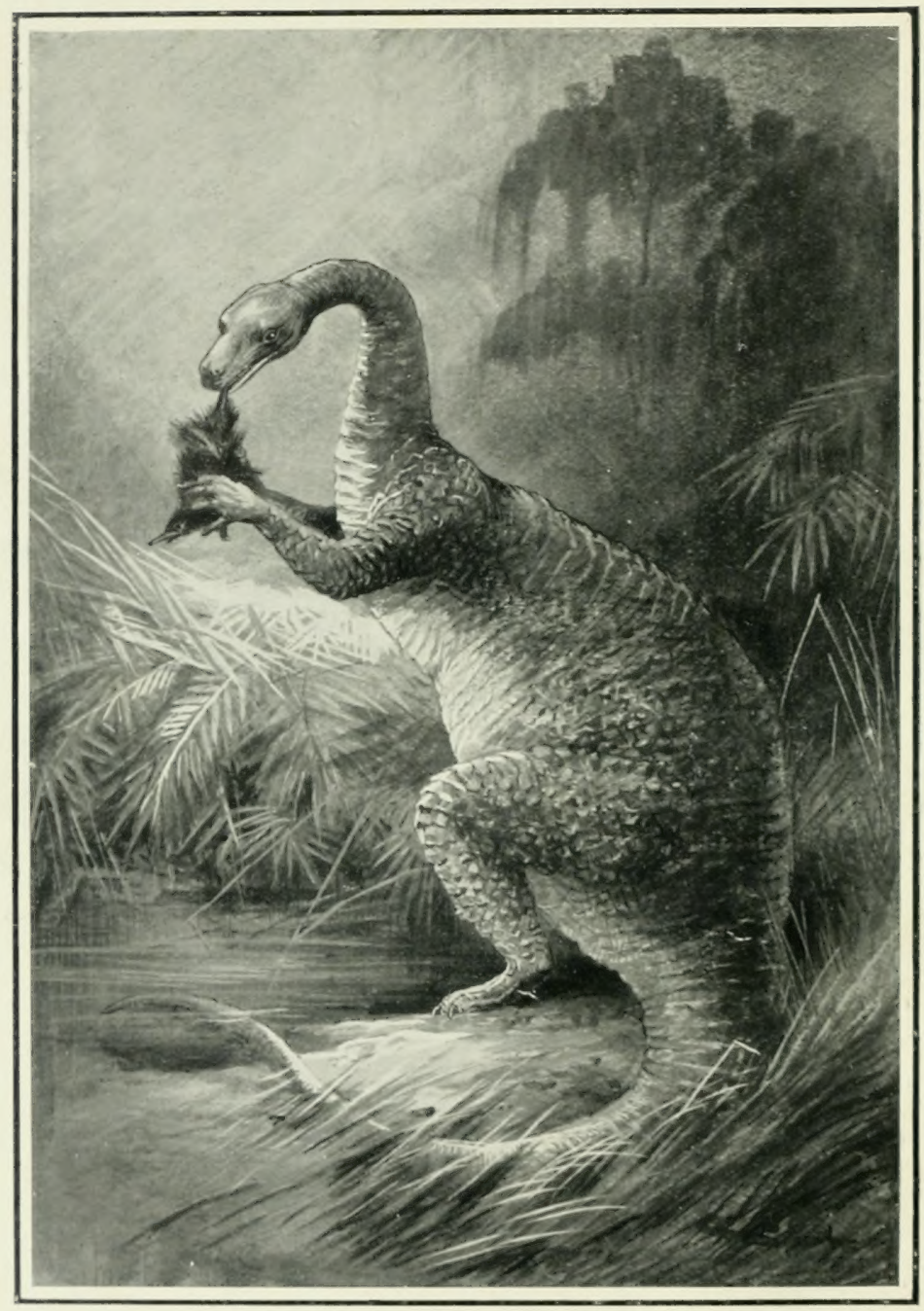

MEgalosaurus

Total length about 25 feet.

(Remains found in England, France, South Africa, and India.) 


\section{THE ROMANCE OF}

\section{MODERN GEOLOGY}

DESCRIBING IN SIMPLE BUT EXACT LANGUAGE THE MAKING OF THE EARTH WITH SOME ACCOUNT OF PREHISTORIC ANIMAL LIFE

BY

E. S. GREW, M.A.

EDITOR OF "KNOWLEDGE"

AUTHOR OF "THE FAR EAST" \&્C., \&્C.

WITH TWENTY-FIVE ILLUSTRATIONS

PHILADELPHIA

J. B. LIPPINCOTT COMPANY

LONDON: SEELEY \& CO. LIMITED 


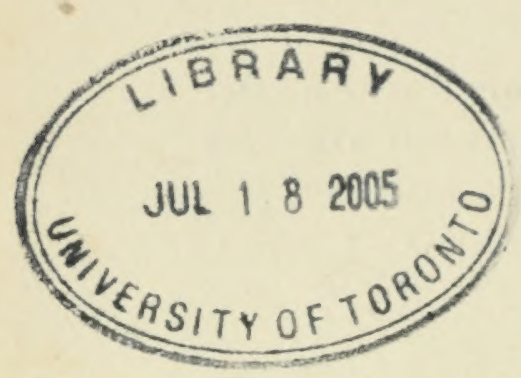

Printed in Great Britain 


\section{CONTENTS}

CHAPTER I
THE BUILDING OF THE EARTH $\quad . \quad \ldots \quad . \quad \ldots \quad$ PAGE

CHAPTER II

THE EARTH'S SHAPE

- $\quad$ - $\quad$.

CHAPTER III

EFFECTS OF WEATHER ON THE EARTH'S HISTORY • - 39

CHAPTER IV

RECORDS LEFT BY RIVERS

CHAPTER V

RECORDS LEFT BY THE SBA

CHAPTER VI

COLD AND ICE ON THE EARTH

CHAPTER VII

THE FIRE-HARDENED ROCKS

CHAPTER VIII

THE EARTH AT ITS BEGINNING . . . . 90

CHAPTER IX

THE CHILDHOOD OF THE EARTH . 


\section{CONTENTS}

CHAPTER $X$

THE EARTH AS THE ABODE OF LIFE

CHAPTER XI

LIPE IN OTHER WORLDS

- 118

CHAPTER XII

THE HARDENING OF ROCKS

- 128

CHAPTER XIII

EARTHQUAKES IN GEOLOGY

CHAPTER XIV

SOME FAMOUS EARTHQUAKES

CHAPTER XV

THE CAUSES OF EARTHQUAKES

- $16_{5}$

CHAPTER XVI

VOLCANOES AND MOUNTAIN FORMATION .

- $\mathbf{1 7 9}$

CHAPTER XVII

FAMILIES OF ROCKS AND THEIR DESCENDANTS

CHAPTER XVIII

HOW THE COAL BEDS IVERE LAID DOWN

CHAPTER XIX

THE AGE OF REPTILES

\section{CHAPTER XX}




\section{CONTENTS}

CHAPTER XXI PAGE

THE CHALK PERIOD

\section{CHAPTER XXII}

THE AGE OF MAMMALS . . . . . . 256

\section{CHAPTER XXIII}

THE ICE AGE

CHAPTER XXIV

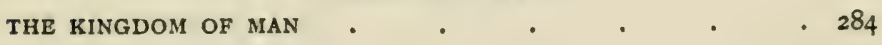

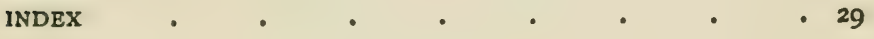





\section{LIST OF ILLUSTRATIONS}

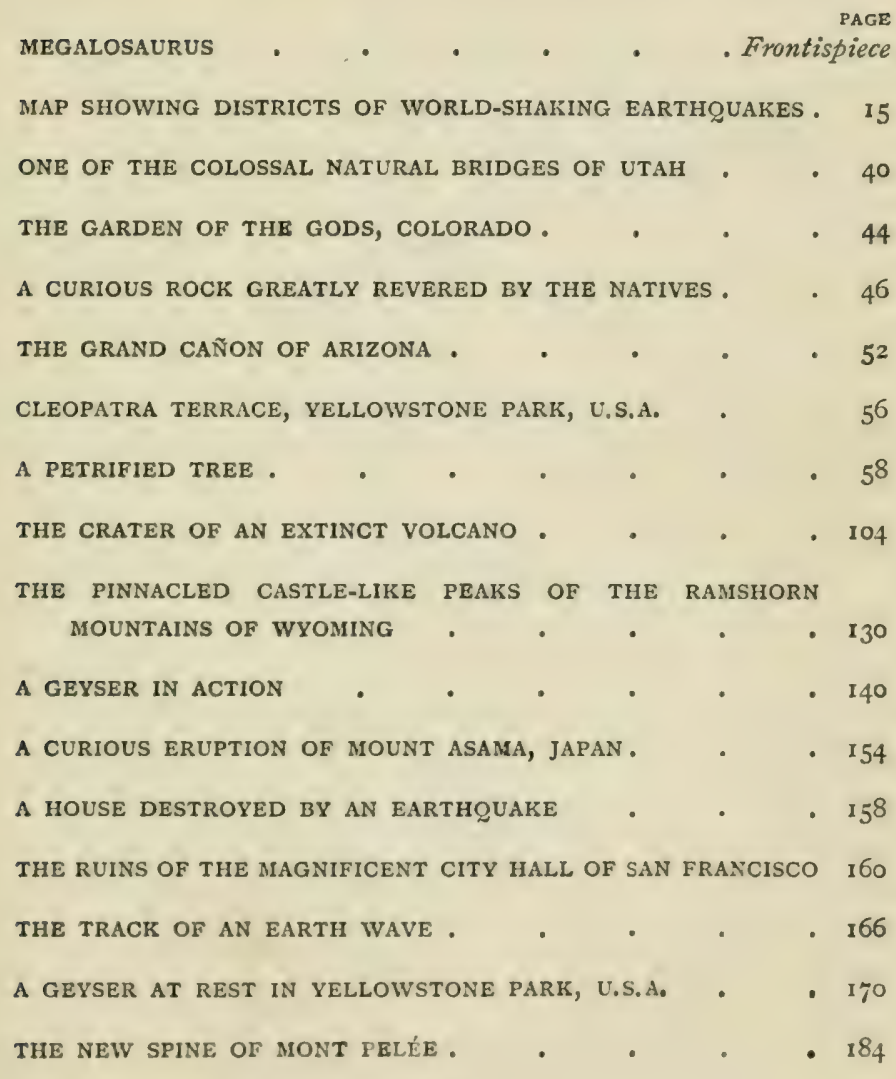




\section{LIST OF ILLUSTRATIONS}

THE DEAD CITY OF ST. PIERRE, MARTINIQUE • . . I86

A YORKSHIRE POT-HOLE : SHOWING THE EFFECTS WHICH CAN

BE PRODUCED IN LIMESTONE BY LNDERGROUND WATER • I 96

PLESIOSAURS $\quad$ - $\quad$ - . $\quad . \quad 238$

DIPLODOCI CARNEGIEI . . . . . . 240

ARCHÆOPTERYX AND COMPSOGNATHUS . . . . 242

EVOLUTION OF THE HEAD, PROBOSCIS, NOSTRILS, AND TUSKS

OF THE ELEPHANT . . . . . . 260

TWO ARSINOITHERIUMS AT BAY BEFORE A PACK OF HYENODONS 266 DIPROTODON 


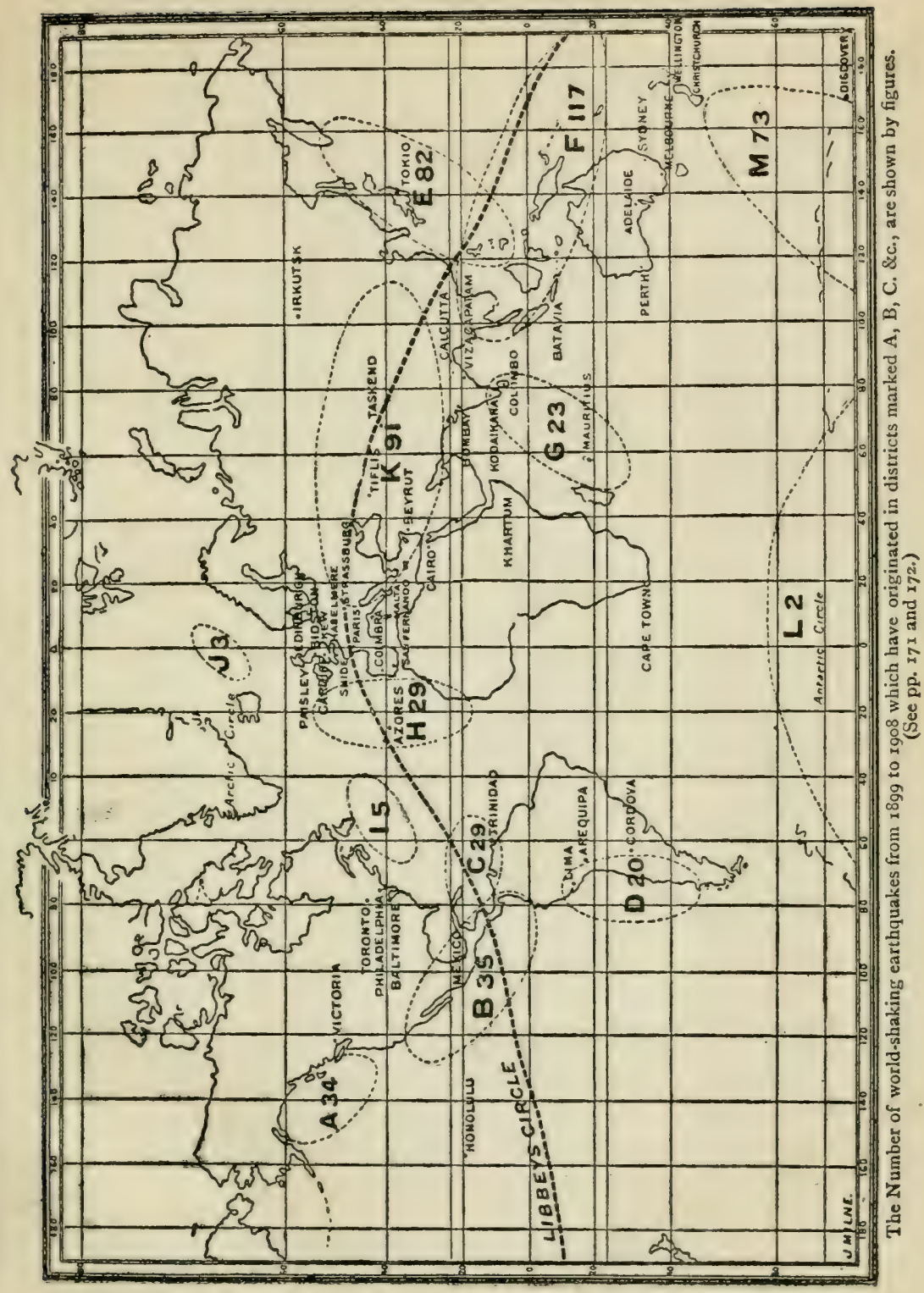





\section{THE ROMANCE OF MODERN GEOLOGY}

\section{CHAPTER I}

\section{THE BUILDING OF THE EARTH}

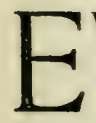

VERYBODY who has ever been to the coast of these islands has become aware that changes in the outline of the land are continually taking place. In some parts of the east coast of England, such as that which lies between Harwich and Walton-on-the-Naze, the sea appears to be slowly encroaching on the land, so that places which were grazing-fields twenty or thirty years ago are now covered by the sea at high tide, and at low tide are mere sandy wastes threaded by rivulets of seawater. On the south coast of the Isle of Wight, between Sandown and the Culver Cliff, which is the most easterly point, the same loss of land is going on in another way. Some years ago a fort stood rather near the edge of the cliff, and it would have been possible to climb round the seaward wall of the fort. It is not possible now, for the outer sea-wall of the fort has long ago slipped into the 


\section{THE BUILDING OF THE EARTH}

sea: so have some of the inner fortifications: and it has been necessary to dismantle the whole of this fort lest every part of even the inner landward wall should follow the outer parts and slip with the solid ground down the cliff. It is easy to see what is happening here. The wind and the waves are undermining and honeycombing the cliff. They are weakening its base and its body, and so the upper crust on which the fort was built, and into which its foundations were dug, is slipping away. If we imagine for a moment that nothing was done to save the fort or protect the cliff, but that all was left to nature to deal with, it would not be hard to picture what would happen. 'The cliff would gradually be eaten away: its gravel and clay would be driwn into the sea, and the Isle of Wight would become a little smaller. The same thing is going on at a good many places along the coast of the British Isles, as well as on the coast of Florida and in the Gulf of California in America.

The little islet of Heligoland in the North Sea, which once belonged to Great Britain, but was some years ngo handed over to Germany, is so fiercely attacked by the sea in this way, that it almost has to be armour-plated in order to preserve its integrity. It is fenced in stone in order to protect it. What is happening on the consts of islands like England and Heligoland is happening all over the world. It has always happened. If it had not happened in past ages there would be no British Isles at all, because once England and Scotland and Ireland were joined to Europe, and it would have been possible to walk across the North Sea from Harwich to the Hook of 


\section{THE BUILDING OF THE EARTH}

Holland. The North Sea was once dry land. But the sea encroached on it from the north, and the Atlantic Ocean battered a way through on the south, till the English Channel was bored through into the shallow waters of the newly-formed North Sea, and the lands that had once been part of Europe became these "sceptred isles set in the silver sea."

This is not all the story. What the sea takes away it gives again. Sir Thomas Holdich is our authority for saying that on some parts of the Pacific coast of America you may at some points see on the one hand dry land which by the shells found on it shows that the sea once flowed over it; while side by side with this raised land you may sail a boat over forests now sunk beneath the sea. The loss of bits and corners of England is seriousso serious that a Royal Commission on Sea Erosion, as the process is called, was appointed to inquire into the extent of the loss and the means by which it might be remedied. But in some parts of our coast the land is not losing, but gaining. If the sea takes away sand and gravel, chalk and shale and clay from the cliffs, these materials are not lost. Something is done with them. They must at some points, where the tides and currents of the sea deposit them, make the sea more shallow. Perhaps the sea lays them down as beds or sand-banks. Perhaps it carrics them round the coast to some other point and there drops them. Can you not see that in this way the sea which at one point is dragging down the coast may at other points be building it up, or may be even constructing break waters made out of these stolen materials? 


\section{THE BUILDING OF THE EARTH}

The sea is not the only carrier which is thus laying down beds of material. The rivers are doing the same thing. Every shower of rain washes some dirt-by which we mean sand or gravel or loam or chalk-from the land into the nearest rivulet. The rivulet hurries with it down to the neighbouring river, and the river carries it down to the sea. If the river is going very fast it carries most of its dirt along with it, and we generally find the river muddy after rain. But when the river slackens its pace, as it usually does when it nears the sea and meets the sea's tides, then it lets the dirt fall; and thus at the river's mouth we find mud-banks or sand-banks. If a river is left long enough to its own devices, these sandbanks will so increase in bulk that the mouth of the river will become shallower and shallower and will spread. It silts up, and when a river is needed for the navigation of ships large sums of money have to be spent, an in the Scheldt or at the mouth of the Thames, in dredging this mud so as to keep the channels clear.

There are many striking examples of this land-building by rivers; and the deltas of rivers, so called from their resemblance to the Greek letter $\Delta$, form in some instances great areas. The Mississippi, the Nile, and the Ganges, for example, are surrounded by great tracts of land at their mouths, which are formed entirely from matter brougl: down by the rivers and deposited at lower levels than those at which the rivers originated. 'The Mississippi, which drains a river basin of $1,147,000$ square miles, has an annual discharge of sediment of no less than 7,459,267,200 cubic feet. 'The Italian River Po, 


\section{THE BUILDING OF THE EARTH}

draining an area of 30,000 square miles, discharges $1,510,13 \%, 000$ cubic feet of sediment annually. This is equivalent to a lowering of its whole drainage area by $\frac{1}{3 \frac{\pi}{3}}$ th of a foot per annum, so that in a thousand years the whole area over which it flows has been lowered by the river by more than a foot. The Thames alone carries down 5,000,000 tons of material each year. All this must be redeposited somewhere. Where the redeposition takes place we find new land forming, new beds, new strata, in which in ages to come the future tenants of the globe may find relics of the people and animals living to-day.

Thus there are several evident ways in which the coast-line of a country might be altered, either in the direction of enlarging its boundaries by additions to it made by the sea or by rivers; or in the direction of losing parts of its territory by wear and tear. But there are other changes going on which are not so easy to perceive, and which are not so easy to account for. The thing hardest to explain is why what is now dry land should have risen out of the sea, as certainly it did. The white cliffs of Dover are made of chalk, and chalk is made of innumerable shells of tiny animals which once lived in the sea and which at their death sank to the sea's bottom. They steadily accumulated there for ages in a grey ooze, and in course of time this grey ooze rose above the waves. It dried and became land. But chalk is not found in cliff's by the sea only. It is found far inland. It is found, for example, in the North Downs, which run from Guildford to Reigate and from Reigate 


\section{THE BUILDING OF THE EAR'TH}

to Limpsfield and Westerham-a great ridge of chalk, at some points 600 to 800 feet high. That ridge must at one time have been at the sea bottom. And if we were to examine the whole of England and sink borings in it, we should at one point or another come to some remains of rocks, or some "strata," as they are called, which are of such make and material that we can only believe them to have been laid down at the sea bottom. The only conclusion we can come to, therefore, is that by some means or other, and at some time or other, the islands of England were slowly lifted above the sea, and that at some other time the sea was slowly lifted above them. What is true of England is true of nearly all the regions of the world that have been closely examined by geologists. Everywhere there is the evidence of different stages of existence in the land's history-stages when it was covered by the sea; stages when it was dry lind again; perhaps stages when it was covered by lakes, by vast forests; stages when it may have been covered by ice; stages when it was desert. Some of these stages show far vaster upheavals thin others, and the changes wrought were of far greater extent. Everybody has heard that the great Saharan desert was perhaps once the bed of an ocean. That is an assertion to which, perhaps, we may be a little chary of committing ourselves; but there is excellent reason for believing that once some of the great African lakes were comnected with the seal: and we are quite certain that once Africa was an island. So that in the case of that rast continent we know that it must have seen periods of great depression and eleva- 


\section{THE BUILDING OF THE EAR'TH}

tion; ages when it was much lower than it is now, and ages when it was higher.

We will not at this moment stop to give further examples. IVe will only try to see whether there is any explanation which would make it possible to understand why there should be these slow upheavals and subsidences of the earth's surface. The chief and most important reason is that the earth is not so solid as it looks, and not so solid as it feels. It would be easier to realise this if, instead of living in a part of the earth like Great Britain, where there are very few earthquakes, we lived in Japan, or Central America, or in the archipelago of islands which runs from Java to Borneo and further south. In these places, where never a year passes but that the earth can be felt to quiver beneath one's feet, and where earthquakes which wreck houses are at least as common as eclipses of the moon, it is easier to believe that the earth is a rather shaky body; or, as scientific men would call it, a rather unstable body. But if, like those scientific men who take up the study of earthquakes, or "seismology," we equipped ourselves with instruments to measure or record earthquakes, we should perceive even in England that the earth is nearly always quivering. Something is always snapping or giving way in its interior, and producing trembling fits that sometimes can be felt hundreds of miles away, and sometimes can be felt all over the earth. There are on the average at least twenty earthquakes a year which make the whole of this round globe tremble.

It would seem, therefore, that either these shocks or 


\section{THE BUILDING OF THE EARTH}

breakages in the earth's crust, or the earth's interior, must be very great indeed, or else that the earth must be composed of rather shaky materials. Well, perhaps both these suppositions are true. We spoke just now of the instruments which seismologists use to record earthquakes. They are known as "seismometers," and a great many of them are used in Japar and on the Californian or Pacific coast of America. Now it is perhaps scarcely necessary to say here (when we recollect how many cyclones and anticyclones England receives from the Atlantic) that a storm or rainy weather is usually heralded or accompanied by a fall in the barometer, or a depression. Now when there is a depression in the barometer that means that the weight of air above the barometer is less than it was before, though it is not so great a difference that human beings could tell it, unless it were accompanied by other signs. But the earth can tell it, and the mere fall of the barometer, owing to changes of the air, will make the earth tremble or quiver slightly, as if it were a jelly. We cannot perceive it; but the delicate seismometers can; and when a storm is coming to Japan or to California from the Pacific, the instruments show that the earth feels the passage of it. The comparison of the earth to a jelly-a very stiff jelly-is on the whole a useful one.

If a very tall jelly is allowed to stand for some time, or if the table on which it stands is shaken a good deal, then, as we know, rifts will sometimes appear in the jelly. 'The reason for these brcakdowns in the jelly's composition 


\section{THE BUILDING OF THE EARTH}

is that owing to the distribution of its weight it is always in what we call a state of strain; and it is sometimes not strong enough to support this strain, and, almost without apparent cause, will sometimes give way. Much more solid bodies than jelly act in the same way. The great bridge near Quebec which collapsed in 1907 was to all appearance quite sound and strong; but there were strains in the iron girders, and without warning these strains suddenly produced rifts in the iron and steel framework and it broke down. Similarly the towers of churches and cathedrals, which are built on arches, will give away quite suddenly after standing to all appearance quite firm for hundreds of years. There is an architect's maxim which runs, "The arch never sleeps." That means that the arches on which the great weight of a church or cathedral tower rests are always in a state of strain; it is always, as it were, imperceptibly quivering; and it is always liable, if the strain on it should be increased in the slightest degree, to give way, or to try to resettle the weight on its shoulders in some way.

The whole of the great globe which we call the earth is in this state of strain; and it is always liable to rifts within itself and to readjustments of the weights of its own parts. It is not so easy to understand how a great globe spinning through space can be in a state of strain, or can attempt to readjust the weight of its parts, as in the instances we have just given of the quivering jelly or the solid cathedral tower. Perhaps another illustration may help us. We will presume that nearly everybody is acquainted with the modern rubber-cored golf ball. The 


\section{THE BUILDING OF THE EAT'TH}

modern golf ball, as those who are aware who either intentionally or unintentionally have cut through its outer cover, consists first of a small hard core. Round this is wound very tightly some two hundred yards of elastic. The tighter this is wound the better, or at any rate the more "bouncing" will be the resulting ball of indiarubber elastic. But consider what is the usual condition of this rubber-wound ball. Like our jelly it is always in a state of stretch or strain. Even when corered with the outer shell which completes the golf ball, the whole ball is still, we might say, in a state of strain or tension. That is one of the reasons why it bounces, and why it flies better than the old solid ball off the face of a golf club. But if you were to keep a golf ball for a hundred years these strains in its interior would alter and adjust themselves. One result would certainly be that the grolf ball might lose its elasticity. Another result would be that its shape would slightly alter.

Now a golf ball, however carefully it is made, is not always evenly made. It weighs a little more on one side than another; and the best golf balls, those which fly truest and farthest, are those which are most evenly made: so that we might say of them that the centre of their weight was exactly the same as the centre of the ball. If it is not, then the strains in the ball are always pulling it a little more out of shipe; and the ball, as golfers say, flies badly. Now the earth is like a badly nade golf ball. The centre of its weight, or, as we call it, the centre of gravily, is not quite at the centre of the earth. Moreover, owing to the enormous pressures which 


\section{THE BUILDING OF THE EARTH}

exist right through the earth, and which are by no means the same at every place inside the earth, but are, in fact, continually changing, owing to hundreds of causes, the whole of the earth's interior is in a state of unequal strain. What is the consequence that you would expect? Is it not that the earth should always be making efforts to adjust its weight, and, as it were, to distribute it evenly? It has been doing this for millions of years. It has not yet finished.

Lastly, the cover of a golf ball is comparatively a stiff and unyielding substance which does not betray on its surface, if it is allowed to lie at rest, the tensions and strains of the rubber core inside. But the crust of the earth, which we have compared to the golf ball's cover, is not unyielding or rigid. It is practically a part of the case of the earth; and it does show and reflect the strains and tensions of the movements and rifts of the core. So that as in the course of ages the straining core changes, and gives way, alters itself and adjusts itself-so the crust of the earth alters with it. Some of these changes are sudden and violent. Some of them take place very slowly, occupying thousands or hundreds of thousands of years in the gradual process of change; and then perhaps for ages the earth's crust will be slowly sinking in one place and slowly rising in another. Thus, what was once a depression in the earth's surface may be now an elevation; what was once below the level of the sea may be now a continent of land; and what was once land may now have sunk beneath the incoming sea. Thus, what was sandstone rock of the earth's surface may be- 


\section{THE BUILDING OF THE EARTH}

come covered with forest, and the forest may sink below the sea, only to be pushed up again and become dry land a million years later. Each of these changes will leave its mark, each will be accompanied by deposits. The deposits may be regetable matter, trees and mosses, and the growth of swamps, such as coal was first made of ; or they may be the ocean sludge, which at last became chalk or limestone. 


\section{CHAPTER II}

\section{THE EARTH'S SHAPE}

$W^{2}$

E have compared the earth to a golf ball, and as it spins through space, impelled by a force millions of times greater than the strongest driver ever imparted to the best-made "Haskell," its flight and general appearance are not unlike those of the rabber-cored ball. The earth, for one thing, is not smooth; it has roughnesses and corrugations all over its surface, similar to those of a golf ball, though much less regular, and it spins as it flies. But let us now consider the differences. Suppose the golf ball had a spot of water clinging to it as water clings to a greasy spot. Where would the water lie? The first answer that occurs to one is that the water would be shaken off the ball in the course of its flight; and that is, indeed, very likely. But suppose the water were very sticky, or were very much attracted by the golf ball (which is another way of stating the same supposition), where would it lie then? To that we can only say that there does not seem any very evident reason why it should lie on one part of the Hying golf ball more than on any other-if the golf ball were perfectly round. 


\section{THE EARTH'S SHAPE}

That is, on the whole, a reasonable answer. But apply the same reasoning to the question of where the waters of the carth in the shape of oceans ought to lie as they cling to the spinning globe. They cling to the globe, not because they are sticky, but because of the attraction which we say is due to gravity-the force which makes everything in nature attract every other thing, and which makes everything tend to fall to the earth (and to stay there). They do so because the earth, being so very heavy and bulky in comparison with anything in its neighbourhood, has such an enormous pull. How great that pull is may be dimly gathered from the reflection that though the earth is spinning at the rate of a thousand miles an hour, nothing is ever shaken off. The oceans are not shaken off. They cling. But why is it that they are not equally distributed all over the face of the earth? If a map of the earth be examined, or still better a globe with the oceans and continents correctly drawn on it, it will be found that there is a great mass of land all lying grouped together on one side of the earth, and a great basin of waters on the other. Let the reader imagine himself a thousand miles above the earth, looking down at a point in it about midway between Madeira and the Bcrmudas. IVhat would he see? He would see the Atlantic Ocean, but all around it would be grouped great masses of land-Europe, Africa, North America, Asia-and if it were his first sight of the earth and he knew nothing of its geography, he would be likely to suppose that the earth was nearly all land, with one comparatively small stretch of unfrozen 


\section{THE EARTH'S SHAPE}

ocean. But now let the reader move round the earth to a point exactly opposite that at which he took his first observations and look down again. He will now see the Australian continent and the land which covers the South Pole, but except for the pointed tail of South America, and perhaps a glimpse of the blunter point of South Africa, he will be looking down on a globe which seems to be largely covered with water.

Why should this be? It must be due to the shape of the earth. The fact is, the earth would make a very bad golf ball. It is by no means of that perfection of symmetry which they say enables a golf ball to fly well and to run true on the putting greens. The earth is, in fact, not perfect as a sphere, either within or without. Its centre is not in the same place as the centre of its weight, and it is not round in shape. Everybody has heard that the earth is slightly flattened at the poles; but its irregularity goes much further than that. If we could strip it of its oceans, which fill up a good many of its imperfections, we should find its shape not that of a neat, round golf ball at all. The earth's actual shape without its oceans, its "geoid," as it is called, is that of a pear. The stalk of the pear is in the southern part of Australia, and contains Australasia and the Antarctic continent. This is surrounded on all sides but one (towards South America) by a sort of belt of depression in which the waters lie. That is the waist of the pear. This again is surrounded on all sides but one (towards the east of Jipan) by a belt of elevation. That is the protuberant part of the pear, and here the great con- 


\section{THE EARTH'S SHAPE}

tinental land areas rise. Finally, we find the nose of the pear in the central Atlantic, between the Madeiras and the Bermudas. Of course, the resemblance to a pear is not a very marked one. Our observer a thousand miles above the earth would not be able to perceive it, nor would the astronomers in the moon, if any astronomers existed there. But the earth is pear-shaped to a small extent nevertheless, and in the case of such an enormous mass a very slight deviation from rotundity will produce very great effects.

Most of us have played at such ball games as bowls or billiards; and I have assumed that everybody knows something about golf. What happens in a game at bowls to the bowl which is not evenly weighted all through? It will not run straight. It has a bias. What happens to a billiard ball which is not perfectly round, or has lost its symmetry through age? It wobbles. And what happens to a badly made golf ball? That performs all sorts of exasperating antics. It ducks, it soars, it curls, it takes a slice. It also wobbles. Now that is exactly what the spinning, unevenly shaped globe which we call the earth has been doing for millions of years. It has been wobbling; and as we showed in the last chapter, it has always been trying to right itself. Thus the two poles have not always been in the same position; the oceans have not always been where they are. The waters have sometimes crawled up the land towards the poles and sometimes receded. Regions that have sometimes been frozen and cold have become warmer, and have covered themselves now with oceans, and now with 


\section{THE EARTH'S SHAPE}

forests, and now with deserts. There is no corner of the whole world which has not undergone changes of climate. These changes are very slow. There is no reason for supposing, in spite of the laments we sometimes hear about the loss of old-fashioned winters and old-fashioned summers, that the climate of England, for example, has changed in the least since Cæsar's legions landed on its shores. The Roman settlers in Britain doubtless experienced sloppy winters and wet summers now and again, just as we do; and King Arthur's knights, no doubt, had their saddening experiences of November fogs. Yet slowly and surely changes of climate do take place, and nothing except the winds influence them more than does the presence of a neighbouring sea or ocean. Most of us reckon the warmth of a locality's climate by the distance it is from the pole. 'That is, however, a very rough and ready method. Vladivostok is roughly the same distance from the North Pole as Venice; but there is a good deal of difference in the temperature of the two places. In Manchuria when the Russians and Japanese were entrenched before Mukden men died of cold and were frozen at their posts at a time when other people in Mentone and Monte Carlo, at the same distance from the Arctic Circle, were complaining of the heat. So that we see that it must not be assumed that a place like England (where for two thousand years we occasionally have had winters that would kill trees like eucalyptus or fig trees, and where oranges could never ripen in the open air) was always equally cold. It may have been, 


\section{THE EARTH'S SHAPE}

in fact we know it must have been, warm enough once to encourage and support what resembled a tropical regetation. It must also have been at one time as cold as Siberia in the winter.

Therefore we should expect to find, if we digrged down in the earth, or in any portion of the earth which had undergone these changes, some traces of them. For example, if at one time the sea corered England for thousands or hundreds of thousands of years, depositing the remains of millions of animals on the sea's bottom during that period, we should expect to find some traces of these remains-perhaps in the form of chalk, seeing that the bones and shells of fishes dwelling in the sea contain a good deal of lime. Or again, if a forest covered England and grew and decayed there, not merely for a period like that which has elapsed since the Romans first set foot in Britain, but for a hundred times as long, we should expect to find some sort of regretable deposit, hardened most probably by other layers above it. Do we? Well, coal is a vegetable deposit. If there was a time when ice covered the land we should expect to find traces of that; if a time when the land was desert; or when it was a lake-each and every one of these periods ought to leave some remains, some epitaph of itself. So they do.

Let us for a moment consider with Sir Archibald Geikie $^{1}$ the subsoil bencath cities that have been inhabited for many centuries. In London, for example, when excavations are made for drainage, building, and other purposes, there are sometimes found, many feet

${ }^{1}$ Sir Archibald Geikie’s Introcluction to Geology. 


\section{THE EARTH'S SHAPE}

below the level of the present streets, mosaic pavements and foundations, together with earthern vessels, bronze implements, ornaments, coins, and other relics of Roman time. Now if we knew nothing from actual authentic history of the evidence of such a people as the Romans these discoveries deep beneath the surface of modern London would prove that long before the present streets were built the site of the city was occupied by a civilised race which employed bronze and iron for the useful purposes of life, had a metal coinage, and showed not a little artistic skill in its pottery, glass, and sculpture. But down beneath the rubbish wherein the Roman remains are embedded lie gravels and sands from which rudely fashioned human implements of flint, arrow-heads, hammers, and the like have been obtained. From that we learn that before the Romans came an earlier race had been there which employed weapons and instruments of roughly chipped flint.

We have no doubt that this was the order of the successive peoples occupying the site of London. It is obvious. Why is it? We see that there are, broadly, three layers or deposits. The upper layer is that which encloses the foundations and rubbish of our own era and times. Next below is that which encloses the relics of Roman occupation. At the bottom lies that which encloses the scanty traces of the early flint-folk. The uppermost deposit is necessarily the newest, for it could not be laid down until after the accumulation of those below it; and those below it must be progressively older, as they are traced deeper from the surface. By the mere 


\section{'THE EARTH'S SHAPE}

fact that the layers lie one above the other we are furnished with a simple clue which enables us to determine the order of their formation. We may know nothing whatever as to how old they are, measured by years or centuries. But we can be absolutely certain that the bottom layer came first, and the top layer came last. This kind of observation will enable us to find proofs everywhere that the surface of the land has not always been what it is to-day. In some districts, for example, when the dark layer of soil in which regetables grow is turned up, there may be found beneath it sand and gravel full of smooth, well-rounded stones. Such materials are to be seen in course of formation where water keeps them moving to and fro, as on the beds of rivers, the margins of lakes, or the shallow shores of the sea. Wherever smooth-rolled pebbles occur they point to the influence of moving water, so that we conclude, even though the site is now dry, that water once moved above it. Again, below the soil in other regions lie layers of oysters and other sea shells.

Pits, quarries, and mines that cut down still deeper into the earth and lay it bare bring before our eyes most impressive testimony regarding the ancient changes of the land. Suppose, by way of further illustration, that underneath a bed of sand full of oyster shells there lies a dark brown band of peat. This substance, composed of mosses and other water-loving plants, is formed in bogrgy places by the growth of marshy vegetation. Below the peat there might occur a layer of soft white marl full of lake shells, such as may be observed on the bottom of 


\section{THE EARTH'S SHAPE}

many lakes at the present time. These three layersoyster beds, peat, and marl-would be like a family pedigree showing the history of the place. The bottom layer of white marl would show that there was once a lake. The next layer of peat would show that by the growth of marshy vegetation the lake became choked up and was gradually changed into a swamp and then a morass. The other layer of oyster shells would show that the ground was afterwards submerged by the sea. The present condition of the ground would show that the sea at last retired, and the place passed into dry land as it is to-day.

By such a method of examination we may frame for ourselves pictures of the earth's surface long before history began, or before man roamed the earth. It is for this reason that geology has been called the science that investigates the history of the earth. The records in which this history is chronicled are the soils and rocks underneath our feet. It is the task of the geologist so to arrange and interpret these records as to show through what successive changes the globe has passed, and how the dry land came to wear the aspect which it presents at the present time.

To do this efficiently the geologist has to learn many things. He has to observe very closely the changes which are going on about him on the world's surface. Only in so far as he makes himself acquainted with these sudden changes can he hope to follow intelligently and successfully the story of earlier phases in the earth's progress. Nor is it sufficient to observe, however closely, inanimate 


\section{THE EARTH'S SHAPE}

things. If he did not know the peculiarities of freshwater shells, how would he be able to say the shells in the marl deposit were fresh-water animals (and that therefore a lake once lay there) and not sea shells. If the labour of the geologist were concerned merely with the former changes of the earth's surface-how sea and land have changed places, how rivers have altered their courses, how valleys have been dug out, and how mountains have been carved, how plains have been spread out, and how all these things have been written on the framework of the earth-he would still feel one very great want, the want of living interest. But that also his science gives him, for in these past eras living things dwelt and moved and had their being. And it is one of the most entrancing pursuits of the geologist to trace their lives, their descent and ascent, and the relies of themselves that they left. 


\section{CHAP'TER III}

\section{EFFECTS OF WEATHER ON THE EARTH'S HISTORY}

HE same causes that produced the layers of peat or sand, or limestone, or clay, which we find by examination of the earth's surface, are acting to-day. Coal is forming now; and so is limestone; and so is sandstone; so even is granite. But these layers or strata form very slowly, so that since man has kept historical records the thickness of new strata laid down could be measured in inches. Consequently we are only able to see the beginnings of the processes. After the materials were laid down by water or the shifting winds, or by the decay of other materials already in position, they underwent various changes. For example, many layers, instead of consisting of loose materials such as gravel, sand, or mud, are now hard stone. Sometimes this consolidation has been the result of pressure. As bed was piled over bed those at the bottom would be more and more compressed by the increasing weight of those laid down upon them; the water would be squeered out; the particles would stick closer together. Mud, for example, might thus turn into clay; 


\section{EFFECT'S OF WEATHER}

and clay, pressed harder and harder, might be converted into mudstone or shale. But there is another agency at work. We have all seen mortar hardening and binding bricks together; or cement hardening into concrete. Similarly sedimentary deposits are bound together by cements, of which there are many which exist naturally. For example, silica is a natural cement; and so is carbonate of lime; and so is peroxide of iron. All these will bind other particles together. But how do they arrive at the layers of particles? By the same action which lays down the particles themselves. They are rubbed off the places where they exist by the wind or by water. Perhaps they were laid down among the deposited particles of mud or sand. Perhaps they were brought to them by streams or rivers or lakes, and sank with the water into them. In a red sandstone, for example, the quartz grains of the rock may be often observed to be coated with earthy iron peroxide, which serves to bind them together into a rather hard stone. On the other hand, the process is often being reversed. The weather frequently conspires by frost and wind and rain to remove the binding cement, and thereby to allow the stone to return to its original condition of loose sediment.

For millions of years the winds have blown over the surface of the earth, the rain has fallen on it, the sun heated it by day, the frost cracked it. Consider the winds that have circled the earth. All movements of the air are due in the first place to the sun which heats the atmosphere and causes it to expand. 'The sun's rays passing through the air do not heat it at once, or 


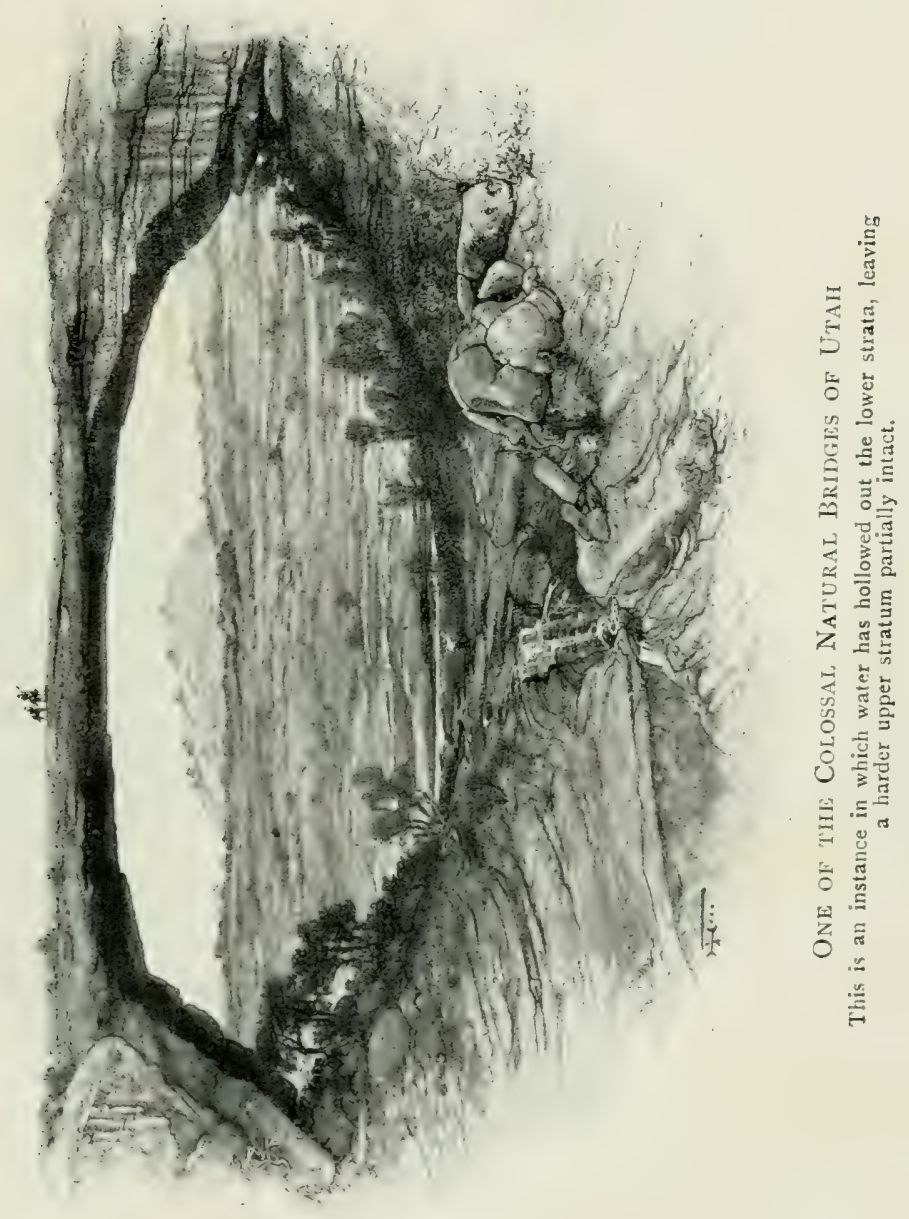





\section{ON THE EAR'TH'S HISTORY}

directly, but heat the land and the sea, which absorb some of the rays and reflect others and so warm the air in contact with them. But, as will readily be understood, the land and the sea do not absorb and reflect the heat rays in the same way or to the same extent; nor do the sun's rays fall equally or constantly on all portions of the earth's surface. So that from various causes one part of the earth is always being warmed in a different way from other parts, and the air above the earth is being warmed in an immeasurable number of different ways. Even if the earth's surface were all water or all land, we should expect therefore that there would be movements of the air due to unequal heating. If, however, the earth's surface were quite even and uniform, we should expect that there would be a certain evenness and uniformity about the movements of the air. These movements would be due partly to the regular heating and regular cooling of the surface, and partly due to the fact that the earth is spinning round taking the air with it-but not taking it quite evenly. The air does not fit tightly on to the earth. It is rather like a loose, baggy envelope with a tendency to slip as the earth moves round. Furthermore, a point situated on the Equator has much farther to travel in twenty-four hours as the earth spins round than a point situated in the Arctic Circle, where a tape measure placed along one of the parallels of latitude (let us say the eighty-sixth parallel, where Nansen turned back in his search for the Pole) would show the earth's girth there to be, not twenty-four thousand miles, but only so many hundreds. This also would make a 


\section{EFFECTS OF WEA'THER}

difference in the way the air would be whirled round the earth; but we could take this point into consideration, and should be able, if, as we have said, our earth were quite uniform, to say always and at all times of the year in what direction the prevailing wind should blow.

Even with all the earth's irregularities we do know a good deal with certainty about the earth's prevailing winds: the trades; the anti-trades; the south-west monsoon, which sets in so regularly in India that year by year its advent hardly varies by more than a day; and, in the descending scale of regularity, the cast winds that usually sweep England in March, and the prevailing south-westerly to westerly winds which bend most of the young trees of the country a little to the north-east. Besides these regularly or irregularly defined winds, there are certain paths along the earth's surfice where the winds always move like a trout stream with eddies in it. These eddies of the air we call cyclones, and they are continually travelling in one direction. No doubt they arise from the air in one place becoming hotter or moister than in the surrounding regions. As the air grows hotter it becomes lighter and ascends, while the heavier air round it pours in. These eddies always travel eastwards and incline in the northern hemisphere towards the north. They usually originate somewhere on the North American continent, and move across the Atlantic about the pace of a slow railway train, winds whirling round them all the time at a much greater pace. Usually the centres of these eddies bear northward patst the north coast of Scotland to the north-west of Norway. Some- 


\section{ON THE EARTH'S HISTORY}

times, however, they take a more southerly course, keeping to the south of the British Isles and passing over Central Europe on to Siberia, where they appear to die away.

Such are the cyclones which are in the main part responsible for British weather; and the winds that accompany them vary a great deal in strength. They depend on the size of the eddy. If the eddy is a very big one (and sometimes the eddies are thousands of miles across) the winds will not be so strong as in the smaller ones. It is, therefore, the smaller ones which cause the violent storms. In the tropical regions whirling eddies of a rather different character occur. To quote Mr. J. H. N. Stephenson: "Instead of being measured by some hundreds or even thousands of miles, they are usually only some hundreds of yards across; and as we found that the smaller the cyclone the more violent the wind, we shall not be surprised that the wind in these is more violent than anything we ever experience in this part of the world. They are called by many different names; in the West Indies they are known as hurricanes, in the southeast of Asia as typhoons, and in North America as tormadoes. These hurricanes or tornadoes travel much faster than the larger cyclones, and the winds blowing into them are so violent that everything-trees, houses, bridges-are swept before them, and so strong is the indraught of air in the centre that strong walls are sucked in just as a piece of paper is in front of a grate when the fire begins to blaze up; and even heavy metal objects are carried upwards. Fortunately these tornadoes do not 


\section{EFFECTS OF WEATHER}

travel continuously along the ground but bump along it, so to speak, sometimes passing harmlessly overhead, then striking the earth again and causing more havoc. Where they pass over the surface of the sea the water is sometimes sucked in just in the same way, causing what is known as a wutcrspout. These may do even more damage than a tornado on land, for the water is sometimes carried bodily on to the land, sweeping everything away in a deluge. This happened many years ago in the delta of the Ganges, when thousands of people perished."

Now let us see how these winds might leave traces in the geological record. When soil is exposed to the sun its surface becomes dust, and the wind carries it off. Even where turf protects the surface, bare places may always be found whence this covering has been removed. Rabbits and moles bring up the earth to the surface; the earthworms sometimes bring as much as ten tons of earth to the surface of a single acre of turf in the course of a year. The earthworms bring up only the finest particles of mould; and these, of course, are the very particles readily converted into dust and borne away by the wind if they are not washed away by rain. In tropical countries the white ant conveys a prodigious amount of fine earth up into the open air, building walls sometimes sixty feet high. Although, therefore, the layer of vegetable soil which covers the land appears to be a permanent protection, it does not really prevent a large amount of material from being remored even from grassy ground. 'The wind carries this fine dust far and wide over the land, and over the sea as well. After the erup- 


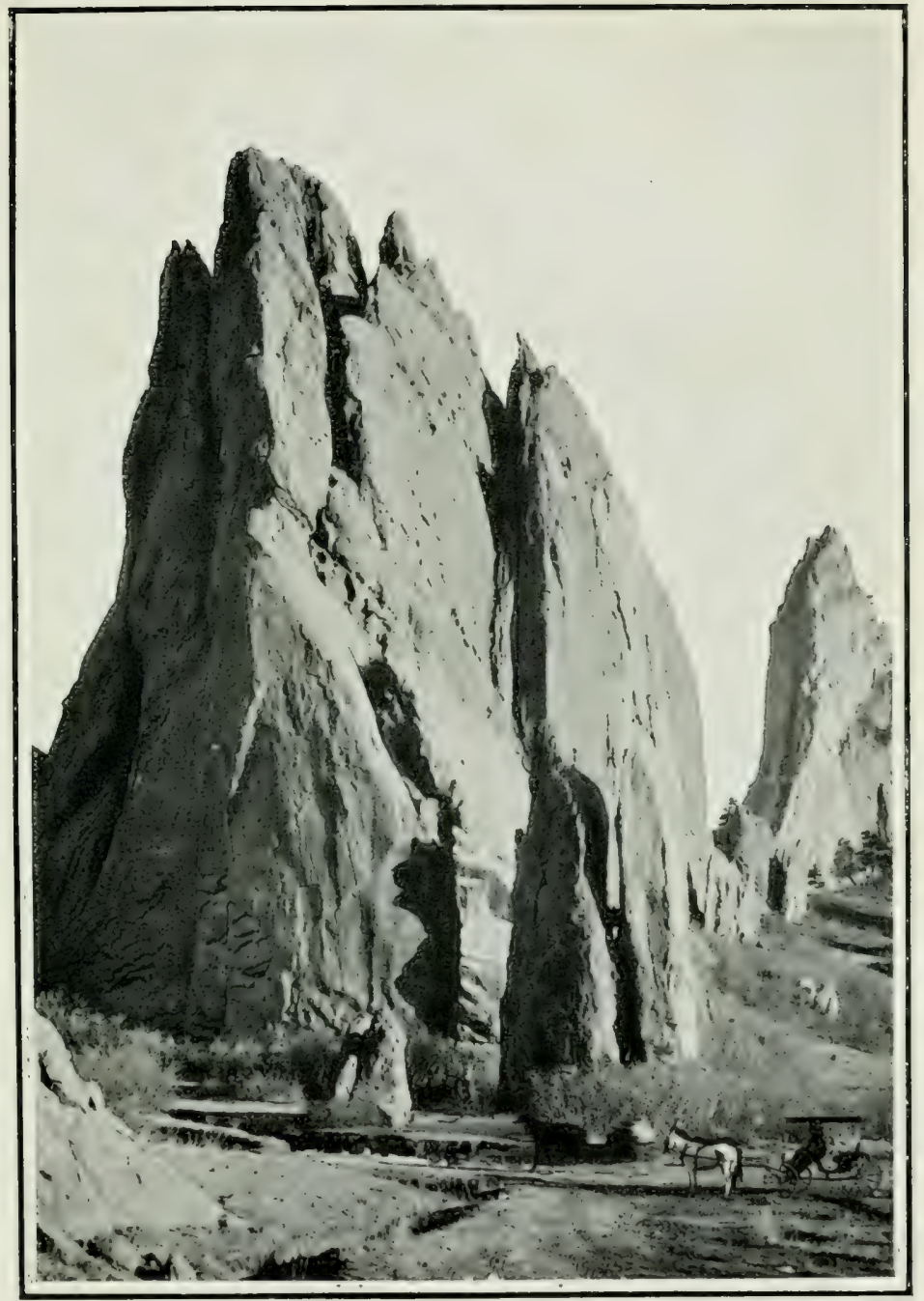

Sieno Copsrigist, I'nderzoood is l'.

London ard' licze yore

THE GARDEN OF THE GOLS, COLORADO

These peak exhibit the sradual wearing away of hard rucks by the action of rain and wind. 



\section{ON THE EAR'TH'S HISTORY}

tion of the island of Krakatoa in 1883, the dust which was the product of that mighty explosion was carried round the world, and even in England we saw the dust particles furnishing extraordinary colours in sunset skies.

In dry countries, especially in the large tracts of Central Asia and of Africa, the air is often so thick with a fine yellow dust that the sun's light struggles through it as through a London fog. The dust settles on everything, and after many centuries a deposit, which may be hundreds of feet deep, is thus accumulated on the surface of the land. Some of the ancient cities of the old world, Nineveh and Babylon for example, after being long abandoned by man, have gradually been buried under the fine soil which the wind blew over them. Even in England the Roman town of Silchester, not far from Reading, after falling into decay when its inhabitants left it, has been buried under the accumulations of two thousand years, and its walls and floors now lie underground and have to be carefully unearthed in order to lay them bare. But we need not seek these exceptional cases in order to perceive what the wind is doing with sand and the fine dust of the earth's uppermost layers. At many places round the coast are sand-dunes. On sandy shores, exposed to the winds that blow off the sea, the sand is dried and carried away from the beach, gathering into long mounds or ridges which run parallel to the coast-line. These ridges are often fifty or sixty feet, sometimes even more than 250 feet high, with deep troughs and irregular hollows between them, and they sometimes form a strip several miles broad bordering the 


\section{EFFECTS OF WEATHER}

sea. These sand-hills creep farther inland, till their progress is stopped by the fields or woods they encounter, or till, by seeds finding a root, vegetation springs up on them and they harden and consolidate under the influence of their own vegetation and move inland no farther. But in many parts of Western Europe and Eastern America the dunes are marching inland at the rate of twenty feet a year. Off the coast of Friesland and North Germany the danger has grown so threatening that scientific attention has been given to the problem; and the German scientific men have employed ingenious devices of planting wind-stakes-something like the wooden breakwaters that are to be found along every seaside beach, but arranged at different angles, - of forcing the sand-dune to heap itsclf up so as to form an obstruction to further arrivals; or of sowing those plants in the sand that will bind its particles together, in order to prescrve the land from further invasion.

What goes on along the coast finds a parallel in the interior of continents where, as in Arizona, in America, or by the desert of Gobi, in Asia, or in the Karroo of South Africa, or in Central Australia and Africa, there is great dryness of climate and a continual disintegration of the surface rocks. Sometimes the dust or sand remains and gradually consolidates or hardens. More often it is only a temporary visitor. Wind and rain are continually removing it, sometimes in vast quantities, into the sea; and in the course of time the most astounding changes are wrought in the surface and appearance of the land. 'The softer rocks are worn down: the 


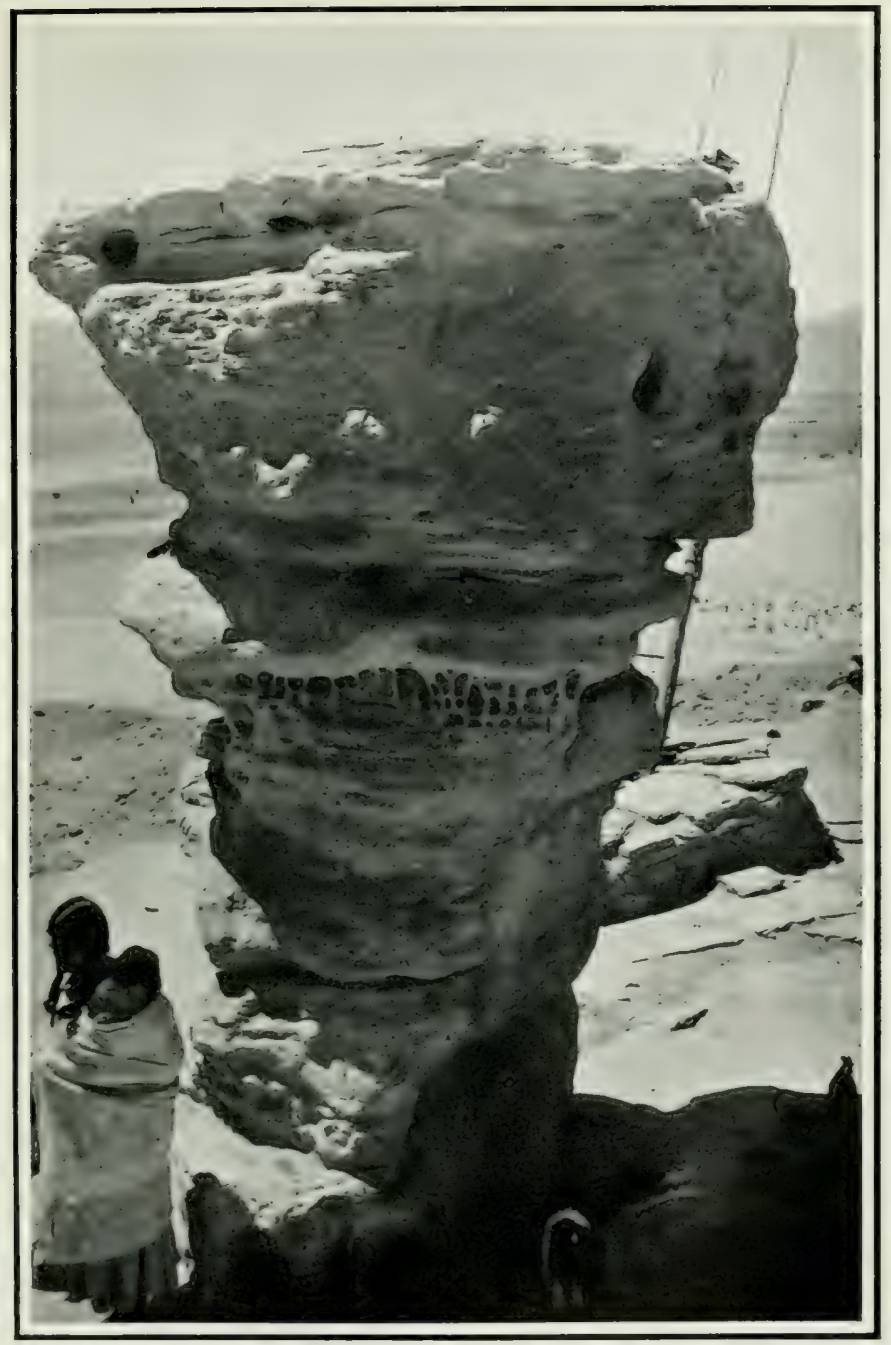

A CuRIOUS ROCK GREATLY REVERFD BY THE NATIVES

This is the Dance Rock of the Walpi Indians of Arizona. Its curious shape is the result of weathering. 



\section{ON THE EARTH'S HISTORY}

harder ones are left sticking out. Gradually the surface is carved out into heights and hollows. The harder rocks become the hills and ridges; the softer rocks are worn into valleys and plains. If there were no water left on the earth's surface a great deal of this process would still go on. In some respects it might become more violent, for owing to the absence of moisture the winds of the earth would always be laden with fine particles; and every one who has seen a "sand-blast" at work, or even the modified sand-blast which is sometimes used for cleaning the stonework of some of our cities, will appreciate what a tornado laden with sand grains might do in the way of destroying the surface of any rock on which it was playing. But, as a matter of fact, the action of water in carving the surface of the earth is the most important of all the factors we have at present to consider.

As rain falls from the clouds it absorbs the gases of the air, including oxygen and carbonic acid. Now both these are what we call corroding agents. If water is allowed to fall on a steel knife the knife rusts; but it has been shown by Dr. Gerald Moody, during the last few years, that if there were no acid gas present, the rusting would not take place. Oxygen and carbonic acid will rust other things beside metal; they will rust stone. Moreover, when the rain reaches the earth it absorbs any other acids of the soil which rotting vegetation may afford, and reinforced by these it goes on to attack the stones over which it flows. When it rolls along as a brook or a river it is no doubt attacking in this way the rocks 


\section{EFFECTS OF WEATHER}

and stones of its channel, though this action is not very strikingly shown. But sometimes the rusting or dissolving action of water is very evident. When it issues from a peat bog, for example, and is consequently highly charged with acid, it will make a very great impression on any limestones it may encounter; for as any schoolboy knows who has ever put a piece of chalk in vinegar, or in any of the stronger acids of the school laboratory, all the limestones are peculiarly susceptible to this form of chemical attack. Peat-water eats into limestone rapidly, while the limestone above the stream escapes, though it is a little (and much more slowly) dissolved by rain. Hence arise some curious features in the scenery of limestone districts. 'The walls of limestone above the water are not eaten away so fast as their base over which the water flows. Consequently they are undermined and are sometimes cut into tunnels and caverns and caves.

The rivers carry away the dissolved material. The carbonate of lime is taken to the sea; and this substance, of which sea shells, for example, are principally formed, is constantly supplied to the sea by the rivers that transport it from the land. The rivers of Western Europe have been known to convey one part of dissolved mineral matter in every 5000 parts of water, and of this mineral matter one half is carbonate of lime. The Rhine alone bears enough carbonate of lime to the sea every year to make $332,000,000,000$ oyster shells of the usual size. The Thames conveys 180,000 tons of sulphate of lime past London every year. It has been computed that more than $8,000,000$ tons of dissolved mineral matter are re- 


\section{ON THE EAR'TH'S HISTORY}

moved from the rocks of England and Wales in one year. That is equivalent to a general lowering of the surface of the country, by chemical solution alone, at the rate of one foot in 13,000 years. That is not much, it may seem; but in a million years, which is not a long period in geological time, half the present towns of England would be sunk under water by this cause alone. 


\section{CHAP'TER IV}

\section{RECORDS LEF'I BY RIVERS}

W

THEN we come to examine more closely the work which rivers do in removing mineral substances from the land by washing particles of them from the surface, we find that the records they leave in geological history must be plainly marked. Every stream, large or small, is always busy carrying mud, sand, or gravel. Rivers are the "navies" of geology. When they are swollen by rain they sweep large stones away with them. If we look at the bed of a mountain torrent we shall often see huge blocks of stone that have fallen from the cliffs on either side blocking the pathway of the stream. 'To all appearance the stream is quite powerless to remove these blocks, and has to circumnarigate them. But visit such a torrent when the snows are melting, or heavy rain has fallen, and you will hear the stones knocking against each other or on the rocky bottom as they are driven downwards by the flood. It is not easy to estimate the driving power of water. M. Gustave le Bon has furnished an illustration of its power which is very curious. In the south of France a stream is led downwards from the mountains to drive the turbine of some machinery at 


\section{RECORDS LEFT BY RIVERS}

a manufactory. It comes down several thousand feet. In the manufactory there is a vent-hole, out of which the water can be allowed to shoot. The vent-hole is about an inch in diameter; and the water rushes out with such swiftness and force that the water-jet becomes as rigid as steel. It is impossible to cut through this water-jet; and if any one were to try to do so with a sword, the sword might break but it could never pierce or pass through those swiftly moving particles of water. A more commonplace illustration is the use that is sometimes made of water-jets to break up the surfaces of rock in quarries; nor must it be forgotten that horse-power of great value and extent for electric lighting and other purposes is always being drawn from waterfalls. Thus as a mechanical force merely the river can be immensely powerful; and must leave marks of its power on the rocks.

The aspect of its force with which we are, however, most concerned is that which is directed to lowering gradually the surface of the land. In the last chapter we showed how much mineral might be dissolved in the waters of rivers. If we are to include also the amount of mud, sand, and other things classed altogether as silt which a river carries down, the figures become much more imposing. Sir Archibald Geikie says that, taking the Mississippi as a typical river (it is as good an example as would be found, because in its great length it passes through many different kinds of land, soil, and climate), we may assume that the average amount of sediment carried down hy a river is one part of sediment to every 1500 parts of water. 


\section{RECORDS LEFT BY RIVERS}

If now, says he, we assume that all over the world this is the amount carried lown, we can see how serionsly the level of the land is lowered by rivers. The Mississippi carries from the land it drains every year the so of a foot of rock. If we take the general height of the land of the whole globe to be 2100 feet, and suppose it to be continuously wasted at this rate, then the whole dry land would be carried into the sea in 12,600,000 years. Or if we assume the average height of the continent of Europe to be 940 feet, and to be lowered by its rivers at the same rate, then the last restige of Europe would have disappeared in 8,640,000 years. Such figures are of course not exact; and it must always be remembered that the rivers are merely robbing Peter to pay Paul, and whatever they take away are always putting somewhere else, but we may learn from the foregoing considerations that the lowering of the land is much more rapid than is sometimes supposed. Another thing about the excavating work of rivers has to be remembered. 'The torrents carry sand, shingle, and rock with them, and these very materials act as agents of destruction on the beds of the watercourses. If we want to polish brass or steel we mix emery powder (or something finer or coarser) with the polishing liquid. 'The torrent or river uses sand or shingle as its polishing powder. It then wears out the rock over which it travels, and sometimes carves it into holes or caverns, gorges or ravines. Sometimes the process is varied, as when a stream finds its way over a hard rock which overlies a softer rock. If the arrangement is like that of a series of steps (there may be only one or two 


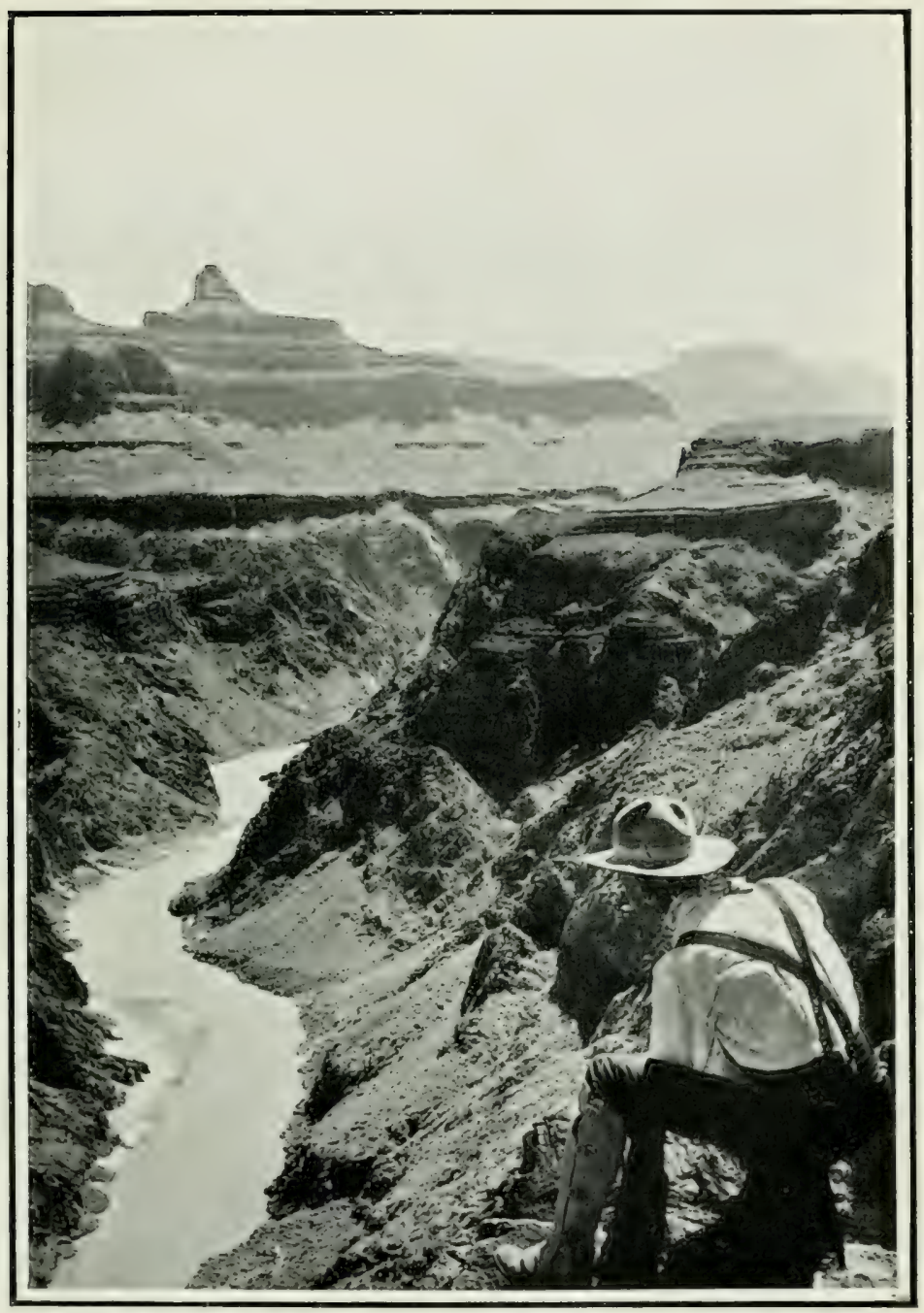

Stereo Copyrighl, I'nt:ravood \& $T$.

oncton art veru bor:

The Grand Cax̃on of Arizona

The Colorado River at this point is nearly 200 feet wide. The man is seated about 1200 feet above the river's level. This whole cainon up to the top of the mountains in the distance has been worn away by prehistoric current; and the river has gradually cut its bed deeper. 


\section{RECORDS LEFT BY RIVERS}

steps) it is possible for the river as it foams in a waterfall over the hard step at the top to eat its way into the lower softer step. The lower softer step will gradually disappear, and then the waterfall, still eating its way in, will begin to undermine the hard top step, and when that has gone on long enough the hard top step will fall down and the waterfall will have to begin a little farther up the stream. In this way a waterfall, gorge, or ravine can be constructed by a river.

The Falls of Niagara are an illustration of this method. The river flows from Lake Erie through a level country for a few miles, then begins to go faster as the path becomes steeper, and finally plunges over a hard limestone precipice. Beneath the hard limestone (the top step) are softer beds of shale and sandstone. As the water eats into them and removes them, large portions of the face of the limestone precipice on the top fall into the stream below. Thus gradually the Falls of Niagara are eating their way back to Lake Erie, and have been doing so for hundreds of thousands of years. In the process of doing so the Niagara River has cut out below the Falls a gorge which is not less than seven miles long, from two hundred to four hundred yards wide, and from two hundred to three hundred feet deep. There is no reason to doubt that the Niagara gorge has been entirely cut out in this way, and that at first the river fell over cliffs seven miles farther down its course at Queenstown. The amount of rock thus tumnelled would make a rampart about twelve feet high and six feet thick going round the world at the Equator. Still more gigantic are the gorges or caverns of 


\section{RECORDS LEFT BY RIVERS}

the Colorado and its tributaries in Western America. The Grand Canon of the Colorado is three hundred miles long, and in some places more than six thousand fect deep. The country traversed by it is a network of deep ravines, at the bottom of which flow the streams that have dug themselves down from the top of the Colorado tableland.

Now suppose that the river has dug itself in as far as it can go. There must be a limit, and the limit is reached when the slope of the bed has been made so slight that the current can only go on languidly. In that case it cannot sweep along stones, or shingle, or even coarse gravel; and then the river so far from deepening its channel begins to raise it by allowing more of the transported sediment to settle down. If a fast stream meets a slower one deposition of material will take place: and the same thing will occur when the rivers meet a lake or a sea. Whatever checks the swiftness of a current weakens its carrying power and causes it to drop some of its sediment to the bottom. Therefore accumulations of sediment occur at the foot of torrent slopes along the lower and more level ground. These deposits we call alluvium, and sometimes when the mountain torrent ends abruptly in the plain they may stand up in cones of silt. They are sometimes called alluizum conc's or funs. Quitting the steep descents, and reinforced by tributaries on either side, the stream ceases to be a torrent and becomes a river. It goes fast enough at first to carry still coarse gravel; but the big angular blocks of rock have been dropped, and the stones it now leaves in its bed are 


\section{RECORDS LEF'T BY RIVERS}

smaller, and become rounded and smoothed as it goes farther and farther across the plain. At many places it deposits gravel or sand, more especially at the inner side of the curves which the stream makes as it winds down the valley. When the stream runs low in summer, strips of bare sand and shingle are seen at each of these bends; and the stones are always well smoothed and lie on the whole regularly. Those that are oblong are so placed that the greater length of the stone points across the stream; those that are flat usually slope upstream. These facts, though apparently insignificant, are really of importance, because they point to us a method by which geology can determine, after a river has disappeared, the slope of the bed and the direction of the curves which once it had. If we examine the steep banks or cliffs by the side of a river the layers of gravel or shingle in the strata may be found to lie not flat on one another but in sloping planes. That at once will furnish a clue to the direction of the river. Another thing of great importance are the terraces which a river forms by the side of itself. When it overflows in floods it deposits mud on either side, and when after the flood it subsides the mud is left. If the reader will imagine the river in the course of ages sinking lower into its bed he will see that successive eras of flood-levels will leave their mark in a series of steps, or river terraces as they are called, on either side of the channel.

But besides the stones and gravel and mud carried down by a river, we must also consider the fate of the remains of plants and animals that are swept along by it, 


\section{RECORDS LEFT BY RIVERS}

especially in flood-time. In any ordinary flood trees and shrubs, and the smaller animals like mice and moles and rabbits, are drowned by the flood. In greater floods birds and even large animals are drowned, and their remains are buried in the sediment. If they are quite covered over they may perhaps be preserved, and their bones may last for an indefinite period. If, further, the mud deposit hardens, these remains may be preserved so well and so long that they become the fossil records of creatures which lived before man emerged to dwell in the world and to become the arbiter of many of its destinies.

What we have said of rivers is true also of lakes. Rivers pour into lakes, bringing with them, especially in flood-time, enormous fieights of gravel, sand, and mud, and mingled with them the remains of regetation and of animal life. Hundreds of thousands of tons may be swept down by one storm. To the Lake of Lucerne, for example, the River Reuss, which comes down from the St. Gothard, brings seven million cubic feet of sediment every year with it. Since the time of the Romans the Rhone has so filled up part of the Lake of Geneva that the Roman harbour, Port Valais, is now nearly two miles from the edge of the lake. The ground between it and the Lake first became marsh. It is now farm land. And though these accumulations are most marked where the rivers drain into the lake, there are deposits always taking place from the hills all round the lake. Thus lake bottoms become most interesting and valuable receptacles of the life that has for ages lived by or near their shores. 'lhese deposits are in many ways 

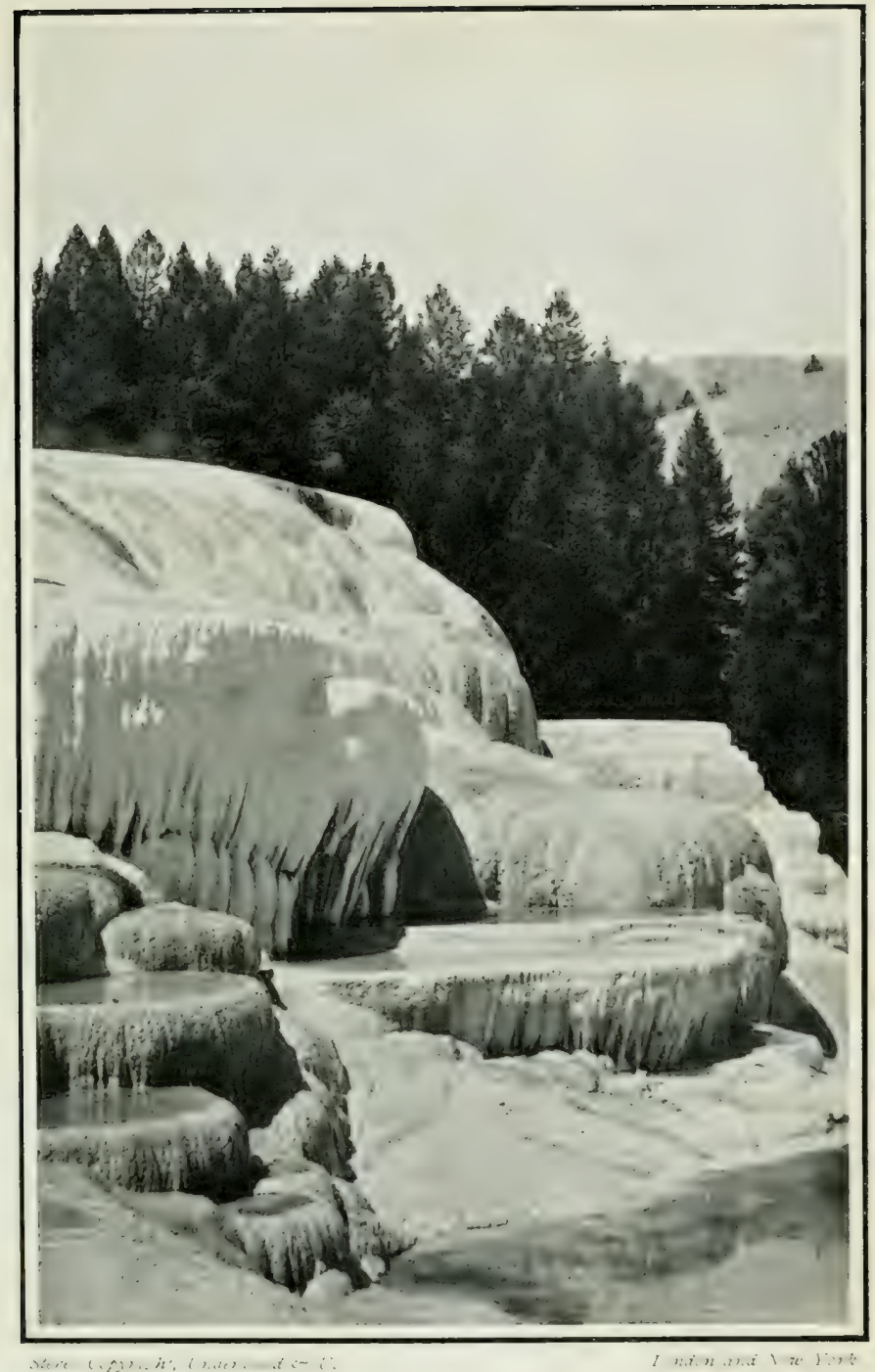

CleOpATRA TERRACE, WITH ITS MIRROR-LIKE POOLS, YELLOWSTONE PARK, U.S.A.

These beautiful basins are formed of incrustations of volcanic limestone. They are of all colours: pink, orange-yellow, green, and blue. The water in them is of a brilliant blue, caused by the growth of water plants (algae), which live in water with as high a temperature as $150^{\circ} \mathrm{F}$. 



\section{RECORDS LEFT BY RIVERS}

peculiar. 'The snails that live in lake waters are distinct from the land snails of the adjoining shores. Their dead shells gather at the bottom of some lakes in such numbers as to form there a deposit of white crumbling marl, sometimes many yards in thickness. On the sites of lakes that have been gradually filled up, or artificially drained, this marl shows at once where the lake borders were, and, roughly, the period of the lake. In some lakes also are found concretions of iron-oxide, which are formed by the chemical action of the water on some of the rocks by the lake-side; and in several Swedish lakes this ironstone forms so fast that the lakes are regularly dredged for it.

Thus among the rozks which form the dry lands of the globe there occur masses of limestone, sand, marl, and other materials which we know were deposited in lakes, because they contain types of plants and animals like those found in the lakes of our own time. From this kind of evidence we can mark out the places of great lakes that have long ago vanished from the face of Europe and North America.

There are also the so-called Salt Lakes to consider. These are generally the lakes that have no outlet and into which a small amount of water now flows, but never enough to cause the lake now to overflow, whatever it may have done in past times. The water that now runs in escapes merely by evaporation. But just as the bottom of a kettle in which hard water is constantly boiled gradually becomes furred, so a lake bottom into which water is continually pouring, bringing dissolved in it all sorts of mineral salts, becomes coated with sediment. 


\section{RECORDS LEFT BY RIVERS}

The mineral salts are not evaporated, consequently the lakes become gradually more mineral-or, for convenience, let us say, become salter. Among the mineral salts common salt and gypsum are most important; but some bitter lakes contain sodium carbonate or magnesium chloride. The Dead Sea and the Great Salt Lake of Utah show by the deposits round them how they have changed their shape and depth. In the upper terraces of the Great Salt Lake, 1000 feet above the present level of the water, fresh-water shells occur, showing that the basin was at first fresh. The valley bottoms around salt lakes are now crusted with gypsum, salt, or other deposits, and their waters are without sign of life. Such conditions help us to understand how great deposits of salt or gypsum were once laid down in England, Poland, and Germany, and in many other places where now the climate would not permit of the necessary evaporation and condensation of the water. 


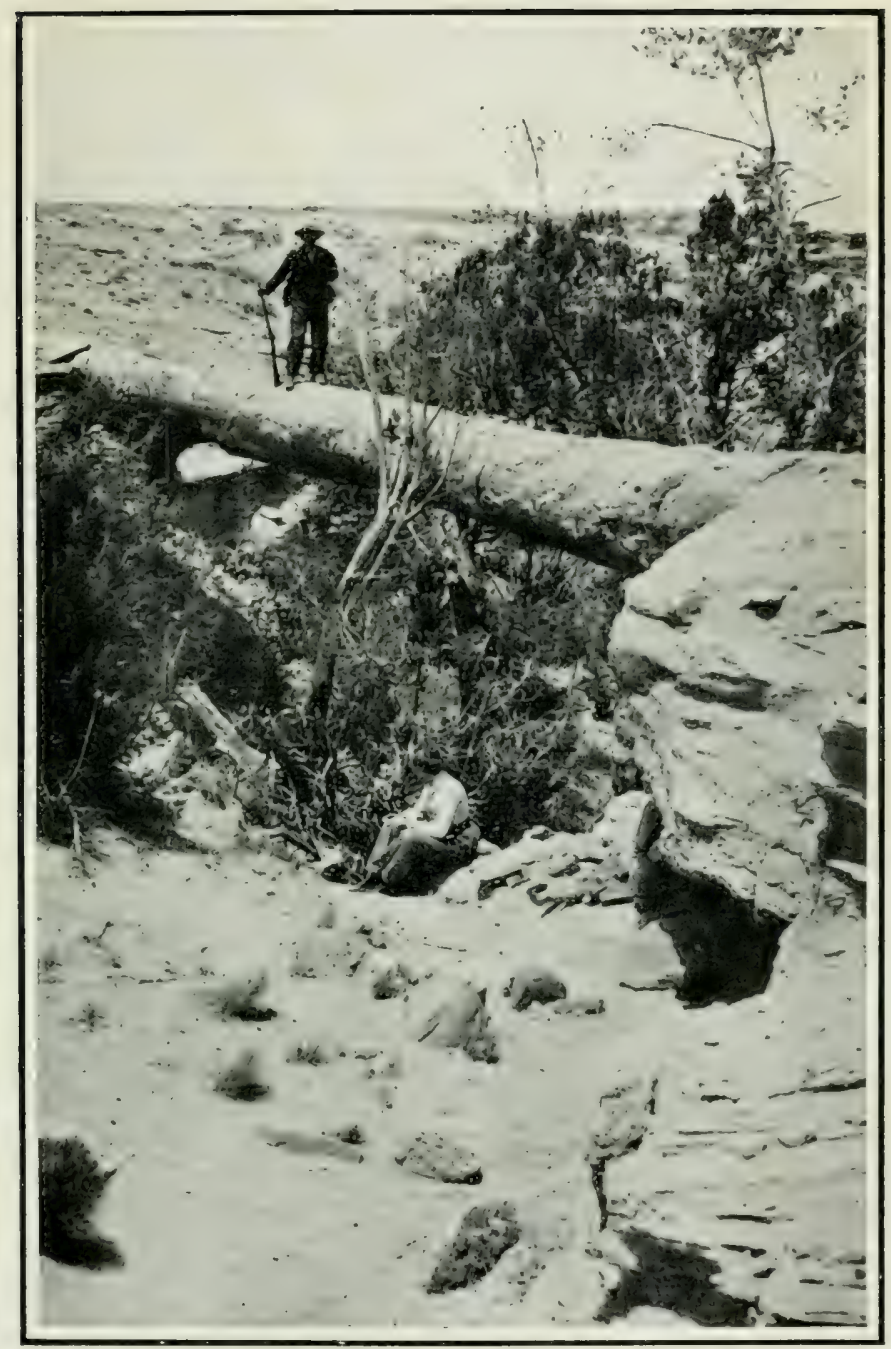

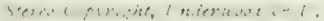

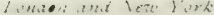

A PETRIFIED TREE

This manificent fossil is in the Petrified Forest of Arizona; and it affords one of the most striking examples known of the solidification and petrifaction of material by the infiltration of mineral salts. The trunk is now not merely encrusted with stone: it is permeated by silica, and is, in fact, itself a stone as hard as flint. 



\section{CHAPTER V}

\section{RECORDS LEFT BY THE SEA}

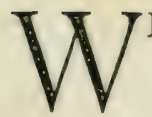

E have already spoken of the story which the sea writes in the annals of geology. It is a story with two plots. In the first place, the sea is always wearing away the land. In the second place, it is arranging on its own bed the materials which it takes from the land, either directly or indirectly. As a sequel to both stories, the materials all neatly ranged, packed, and folded are revealed when the sea subsides from them, or when, in process of one of those great geological changes, the origin of which we have already attempted to account for, the sea bottom is raised to become the land of a continent. The first part of the sea's belligerent story is written so plainly for all eyes to see that one scarcely need dwell on it. Every strip of coast around these islands bears witness to it.

Off Shetland masses of rock twelve or thirteen tons in weight have been cut out from the cliff seventy feet above the smooth-water level. The sea's battering-rams are the masses of shingle, gravel, and loose blocks of stone which it carries with it; but it has subtler methods in the corrosive action of its salts, for just as it rusts or wears away 


\section{RECORDS LEFT BY THE SEA}

iron, so its salts and acids must eat their way into many rocks.

But, after all, the coast-line of the world is a small fraction of the whole land surface of the globe; and a smaller fraction of the sea's own wide area. On that area are flung all the records and treasures which the sea has wrested from the land. The rivers, as we have already several times repeated, are the chief carriers of deposits to the sea. By their deltas they may be known. 'The deltas of the Ganges and Brahmaputra cover an area as large as that of England and IVales. The delta has been bored through to a depth of nearly five hundred feet, and has been found to consist of numerous alternations of fine clays, marls, and sands or sandstones, with occasional layers of gravel. In all this accumulation of sediment there are no traces of marine animals; but land plants and the plants and animals of the river and of the surrounding land have been discovered in quantity. The seal most often destroys land; but it sometimes deposits beaches; and, we might almost say, silts up the land. At liomney Marsh, for example, a tract of eighty square miles which was marsh in Julius Ceesar's time is now dry land, and has become so partly by the natural inercase of shingle thrown up by the waves. The coarsest shingle usually accumulates towards the upper part of the beach, and the rest arranges itself generally according to size and weight, that which is finest being nearest to lowwater mark.

It is often lomg lefore the -luff brought down by the rivers settles on the floor of the ocean. 'The finer particles 


\section{RECORDS LEFT BY THE SEA}

may be carried out to sea for three hundred miles or more before they settle. Within this three-hundred-mile zone the land-derived materials are distributed over the floor in orderly succession. Nearer the land we shall find coarse gravel and sand. Beyond there will be tracts of finer sand and silt, with patches of gravel here and there. Still farther off will come fine blue and green muds, which are made of the tiny particles of such materials as form the ordinary rocks of the land. But when we are once past this zone of land material we come upon deposits which are the ocean's own freehold-materials which it does not derive from the continents, but which may be called oceanic in origin. First there are vast sheets of exceedingly fine red and brown clay. Whence comes it? It is by far the most common deposit in all the deeper parts of the ocean. It may either be the dust of volcanic fragments washed away from volcanic islands, or (which is much more likely) it may be supplied by eruptions under the sea. For it must be remembered that the sea floor is two to five miles nearer the hot rocks that are in the interior of the earth than the land surface is, and that consequently the water coming into contact with them may cause explosions arising from the action of steam. This is a question we shall have to consider later, and for the present we must ask the reader to accept the fact-and read on.

There is one very curious thing about this red clay, and it is that the accumulations of it appear to be built up very slowly. Where it occurs farthest from land great numbers of sharks' teeth with ear bones and other 


\section{RECORDS LEFT BY THE SEA}

bones of whales have been dredged up from it. Some of these relics are quite fresh; others are coated with a crust of brown peroxide of manganese. Some are covered with this material and hidden in it. One haul of an ocean dredge will bring up the bones in all these states, so that they must be lying side by side. The bones are probably those of many generations of animals, and it must take a long time to cover them with the manganese deposit. But the clay is deposited even more slowly than the manganese, so that it must fall very slowly indeed.

But besides these things the bottom of the sea receives deposits of the remains of all kinds of shells, corals, and all sorts of marine creatures, great and small. As the countless myriads of the animals of the sea die, the shells with which they are covered, or the bones which form their framework, fall continually to the bottom of the oceanic gulfs in which they dwell. Then the ocem floor is covered with the remains of tiny animals incomparably more numerous than the stars of the sky; and this grey slimy ooze of organic matter hardens by pressure into sedimentary rock. In the course of ages, when the slow decline of the water lays it bare, it may become part of the land on which men dwell. But it is always forming, has always been forming, since life first appeared on the earth. It is on this ocean floor that man to-day lays his telegraph cables. Mr. Rudyard Kipling, in his verses "The Deep Sea Cables," has drawn a vivid picture of the bed of the deep ocean :-

The wrecks dissolve above us : their dust drops down from afar-

Down to the dark, to the utter dark where the blind white seasnakes are. 


\section{RECORDS LEF'T BY THE SEA}

There is no sound, no echo of sound, in the deserts of the deep,

On the great grey level plains of ooze, where the shell-burred cables creep.

It is in these silent depths that for uncounted and innumerable years the crust of the earth has been forming and has been growing outwards, while it has been slowly hardening inwards above the fires of its unplumbed interior.

It has been calculated that in a square mile of the ocean down to a depth of one hundred fathoms there exist more than sixteen tons of carbonate of lime in the form of the bones or shells of living animals. A continual fine "snow-storm" of dead chalky animals is therefore falling on to the bottom. Here and there, especially among volcanic islands, portions of the sea-bed have been raised up into land and masses of modern limestone. Though these rocks are full of the same kinds of shells as are still living in the neighbouring sea, they have been cemented into hard rock. 'This cementing is due to the water which has penetrated and permeated the stone, dissolving chalky matter from the outside shells, and depositing it once more lower down and farther in, like a fine mortar, so as to bind the mass together.

Every one has heard of coral reefs. They are one of the best and most familiar examples of the way in which great masses of solid rock can be built up by the dead bodies of animals. In the warmer seas of the earth, and notably in the track of the great ocean currents, various kinds of coral polyps, as they are called, take root on the edges and summits of submerged rocks and peaks, as well 


\section{RECORDS LEFT BY THE SEA}

as on the shelving shores of islands. The coral polyp is a jelly-like creature, but it has a hard chalky skeleton inside its transparent body. It is a great colonist, with no liking for a solitary life, but with, on the contrary, a great fancy for its neighbours; in fact, the polyps grow and thrive in clumps, and the clumps unite to form communities, and the communities increase to colonies and nations, till they unite to form what is called a reef. 'The coral polyps are rather exigent in the choice of their residential neighbourhoods. They cannot live at a greater depth than fifteen or twenty fathoms, and in defiance of* the inclinations which rule human beings, they have the strongest distaste for sun and air ; in fact, they die when exposed to it.

Now when the polyp dies its skeleton remains behind it, and millions upon millions of these coral skeletons make a layer of coral. These layers of coral gradually lift the generations of polyps upwards to the surface of the water. But as we have seen, the living polyps die when they get so far, and consequently the reef then spreads outwards. On the outer edges of the reef the coral polyps flourish in the most vigorous way. There they are as completely provided for as in a County Council Utopia. The breakers bring them the food on which they live; the water and the climate suit them exactly. The only blot on their lives are the occasional storms which break off fragments of the coral foundation on which they live. But even this, while it is disastrous to the individual polyp, is for the good of the community, because these 


\section{RECORDS LEFT BY THE SEA}

blocks as they roll down form a new foundation on which new generations of polyps can grow and feed. Moreover, it is better for the polyp to take the risks of these evictions than to vegetate inside the reef, for there in the calmer water he will not have enough to eat, and will dwindle and die. Thus the tendency of all reefs must be to grow seawards, and to increase in breadth. Perhaps their breadth may tell us roughly how old they are. But there is another possibility to be taken into consideration, which is that while the polyps are building the sea bottom or island foundation may be slowly sinking. In that case it is quite likely that the coral builders might just keep pace with the subsiding foundations of their home, and build up a great thickness of coral rock during the countless years of change.

Sir Archibald Geikie has called attention to the swiftness with which the structure of the coral polyp's skeleton is effaced from the foundation and a compact mass of rock put in its place. The sea-water's chemical and dissolving action, and the vast amount of mud and sand produced by the breakers are chiefly responsible for this. As the rock is being formed it is always being cemented. On the portion of a reef laid dry at low water, the coral rock looks in many places as solid and old as some of the ancient white limestones and marbles of the land. In pools where a current of water keeps the grains of coral sand in motion, each grain may be seen to be rounded. This is because on each particle of coral the dissolved carbonate of lime in the water is always being deposited (like the sediment in the bottom of a kettle). 


\section{RECORDS LEF'T BY THE SEA}

A mass of these rounded or egg-like grains all gathered together in a lump is called wolite, from the Greek word "oon" (Latin "orum"), an egg. In many limestones, now forming parts of agricultural land, this oolitic structure is strikingly shown, and there can be no doubt that in such cases it was produced just as now coral reefs are being formed before our eyes. In the coral tracts of the Pacific Ocean there are nearly three hundred coral islands, besides extensive reefs round volcanic islands. Others occur in the Indian Ocean. Coral reefs abound in the West Indian seas, where in many of the islands they have been upraised into dry land-in C'uba to a height of 1100 feet above the sea-level. The Great Barrier Reef that fronts the north-eastern coast of Australia is 1250 miles long and from ten to ninety miles broad.

It will thus be seen that, apart from any other consideration, the animals of past ages leave permanent records of their existence merely by the accumulation of their dead bodics. Nevertheless, alike on land and on sea, the proportions of organic remains thus sealed and preserved is only a small part of the total population of plants and animals living at any given time. 


\section{CHAPTER VI}

\section{COLD AND ICE ON THE EARTH}

7 HE astronomers who look at the planet Mars tell us that at the Northern and Southern Poles there are great areas of snow, very much greater than the arctic regions of the earth, for the south polar area alone occupies $11,330,000$ square miles. But the geological records of the earth show that our own arctic regions once extended very much farther than they do at present, a fact which need not in any way surprise us, for as we have already remarked, snow and ice are very largely a matter of the nearness of the sea to the land. We may put the same thing in another way by saying that winter cold and summer heat depend largely on the distribution of sea and land. Thus Venice, which is not very much farther from the North Pole than Vladivostok, has an altogether different climate, and inhabitants of the Shetland Isles have a very different kind of climatic experience from those who delve by the frozen Yukon. There is another consideration which is sometimes overlooked. We do not think of the earth as a very warm body. But at its very coldest part, where the thermometer goes down to seventy or ninety degrees 


\section{COLD AND ICE ON THE EARTH}

reach the rocky floor over which the ice is sliding. Its progress then resembles that of the Irish gentleman who was travelling in a Sedan chair out of which the seat and the bottom had fallen, and who said that if "twere not for the fashion of the thing he'd as lief walk. The rubbish borne onward on the surface of the glacier is known as moraine-stuff; and the mounds of it at the edge of the glacier are called lateral moraines. Where two glaciers unite like two rivers, their moraines, right-hand and lefthand, will join, and in the new glacier a new moraine will appear running down the middle, and so called a medial moraine. Where a glacier has many tributaries bearing a good deal of moraine-stuff, its surface may be like a bare plain so covered with stones that the ice beneath can hardly be discerned except here and there. At the end of the glacier where the ice melts, the heaps of stones, ever adding to their numbers, are deposited in heaps, to which are given the name of the terminal moraine.

With such tokens of their existence as this, glaciers, as will readily be understood, leave visiting-cards in history that cannot easily be mistaken. Even existing glaciers tell strange stories. Nowadays glaciers are carefully measured and examined both in Switzerland and in Canada. During the last decade of the nineteenth century and the first decade of the twentieth the Swiss grlaciers were found to show signs of receding farther up their valleys. The same thing has been observed about some of the Canadian glaciers. There are severil plausible reasons for this. Professor Schaeberle says that the earth is growing cooler, and that in the temperate regions the winter rainfall 


\section{COLD AND ICE ON THE EARTH}

(which would turn to falls of snow in the mountains) is less than it has been. It is certain that a shortage of winter rain over a number of years in succession would account for the shrinkage of the glaciers, but it is not by any means certain that a number of dry winters will not be followed by wet ones, in which case the glaciers would increase again. Some of the glaciers show that during their existence they have shrunk and lengthened alternately like gutta-percha in a variable climate. How do we know that they have shrunk and lengthened? The moraines of which we have spoken give us the testimony. As a glacier shrinks either in length or in breadth and depth it leaves the blocks of rock at its edges stranded on the sides of the valley. Such perched blocks or crratics are the best of glacier marks, and their great size, sone of them as large as a cheap villa residence, is such that no current of water could have brought them there. They are often poised on the tops of crags, on the very edges of precipices, or on steep slopes, where they could never have been left by any flood, even had the flood been able to move them. The only thing that could have carried them must have been a vehicle that moved very, very slowly and deposited them very, very gently-in fact, glacier ice. We can see blocks like this on the glaciers now, and others stranded at the sides. In the Swiss valleys the scattered ice-borne boulders may be seen by hundreds far above the glaciers and far beyond the places where the glaciers end. We know they must have been left by glaciers, and by inference we surmise that when we find a valley filled with them, then, though the valley 


\section{COLD AND ICE ON THE EAR'TH}

may have no glacier now, it must have once been occupied by one.

These erratic blocks, now found all over Europe, tell us a good deal about the ice on which they were transported. The blocks that fall on the edges of the glacier remain on the side where they descend. Hence, if there is any notable difference in the composition of the rocks on either side of the valley, the existence of this difference will be preserved in the moraincs. If, therefore, in a country where the glaciers have disappeared we can trace the scattered blocks up to their sources among the mountains, we can say what was the track followed by the prehistoric glaciers. In Europe there are several examples of the uses of this detective evidence. 'Thus the peculiar blocks of the Valais mountains can be traced right on to Lyons; and this shows us that the glacier from which the River Rhone sprang extended once right across the east of France to Lyons, and probably farther. It was therefore once at least 170 miles longer. Similarly, blocks which are exactly like the characteristic rocks peculiar to Southern Scandinavia are found in Northern Germany, Belgium, and East Anglia; and we therefore believe that a great sheet of ice once filled up the Baltic and the German Ocean, carrying with it immense numbers of northern "erratics." In our own country, in fact, glacier boulders are found in nearly every county, and show that once the greater part of the country was buried under ice.

But, as we have said, it is not only on its shoulders, but in its interior and beneath its base that a glacier rolls 


\section{COLD AND ICE ON THE EARTH}

and pushes its rubbish along. It is not all stones. Clay and earth mingle with it, often enclosing the stones; and the debris left by extinct glaciers of ages ago is sometimes called the boulder-clay. This is the deposit, earthy and stony, that the glacier leaves on the floor of the valley as it shrinks-unless the river which usually springs from the end of glaciers sweeps it away. Most of the stones thus left are smoothed or polished and covered with scratches or ruts, such as would be made by rubbing against other hard pointed fragments of stone. This is to be explained by the fact that these stones as they were carried on by the glacier were rubbed on the floor of rock over which the glacier was slipping. If their journey was long enough, they stood a chance of being rubbed away altogether and of finishing their existence as sand or mud. What the valley did to the glacier's stones, the stones did to the valley. They scratched it and scored it. Every promontory of rock which stood in the path of the ice had its angles and corners ground away. The polish and the directions of the scratches are especially remarkable, because, whether the marks are mere lines or deep-worn ruts, they are all on smooth surfaces, and they all run one way. That way is the direction in which the glacier moved. How high a degree of polish or how deep the markings may be depends a good deal on the kind of rock over which the glacier moved. 'Tough, close-grained rocks, such as hard limestone, are sometimes polished to look like marble. But there is a great deal of difference between the smoothing effected by a river or a torrent and that 


\section{COLD AND ICE ON THE EAR'TH}

which is produced by a glacier, because the river tosses the rocks and stones in all directions, polishes them on every side, and leaves no distinctive parallel scratches or grooves on them. That can only be done by glaciers which hold the rocks, the rubbers and the rubbed, pressed firmly together and grind them continually in the same way.

These scratchings or striations of rocks, the smoothed and grooved surfaces, and the deposited boulder-clay and boulders enable us to trace the march of great ice-sheets over regions of the earth which are now of totally different aspect. From this kind of evidence we have been able to find that the whole of Northern Europe was once buried under a great expanse of snow and ice. 'The sheet was, as we should expect, thickest in the north and west, and thinned away southward and castward. Over Scandinavia it was between 6000 and 7000 feet in thickness-as we can tell from the scratches on the sides of the high mountains. Similar marks 3000 feet above the sea-level in the Scottish Highlands lead us to believe that over Scotland the glaciers were 5000 feet thick, and even as far south as the Hartz Mountains in Germany it could not have been far short of 1500 feet in thickness. Imagine this great mass of ice ever slowly moving and ever creeping solemnly down to the sea. By the markings it left we can trace where the greater glaciers slid grandly along. In Scandinavia it swept westwards to the Atlantic and eastwards to the Gulf of Bothnia, then frozen as solid as the Pole. Southward the ice ground its way across Denmark to the Low Countries and North Germany. The Baltic was choked with ice, and so was the 


\section{COLD AND ICE ON THE EARTH}

North Sea as far south as London. Ice in that day flowed in glaciers from the British Isles, eastwards from Scotland into the hollow of the North Sea, and westwards down all the clefts of the mountains, burying the western isles and breaking off in icebergs that drifted far into the Atlantic. Sir Archibald Geikie says that the western margin of the ice-fields from the south-west of Ireland to the North Cape of Norway must have presented a vast wall of ice 1200 to 1500 miles long and hundreds of feet high-like that great barrier which the Antarctic explorers tell us frown on the waters that lap the boundaries of the south polar land. Northern Europe must have been like North Greenland of to-day. The rock scratches tell us (since even the southern coast of Ireland is intensely ice-worn) that the edge of ice must have extended some distance beyond Cape Clear, rising out of the sea with a precipitous front that faced to the south. Thence the ice-cliff swung eastwards, passing probably along the line of the British Channel and keeping to the north of the valley of the Thames. Its southern margin ran across what is now Holland and skirted the high grounds of Westphalia, Hanover, and the Hartz Mountains-which probably barred its further progress southward. "There is evidence that the ice swept round into the lowlands of Saxony up to the chain of the Erz, Riesen, and Sudenten Mountains, whence its southern limit turned eastward across Silesia, Poland, and Galicia, and then swung round to the north, passing across Russia by way of Kieff' and Nijni Novgorod to the Arctic Ocean." 


\section{COLD AND ICE ON THE EARTH}

In North America there are similar traces of the great ice-sheet, one of the branches of which streamed southward into the basin of the Mississippi, the second moving westward from Hudson Bay to the Rockies, and southward to Iowa, and the third setting out from the great mountain ranges of British Columbia. Right across North America to-day for thousands of miles stretch accumulations and mounds of rock which were pushed forward by the ice, and were dropped by the glaciers when they reached "farthest south." These accumulations are called, from their origin, the great "terminal moraines" of the North American Ice Age.

It must not be thought that these great ice-sheets of both hemispheres remained constant in extent and thickness. There were periods of retreat and advance, of progress and shrinking, and the shrinkings of these took place on a large scale, and perhaps lasted for hundreds or thousands of years; so that mixed with the strata of boulder-clay, which are the characteristic strata of the glacial periods, are other strata of sand, ordinary clay, and even peat. Remains of plants and animals are found in these strata, showing that sometimes the glaciers retreated so far and for so long that regretation sprang up and animals lived on the ground that they had covered-in the intervals when the cold of centuries was replaced by other centuries of mild and equable climate.

At last, after many of these swallow-like retreats and advances, the warmer climate at length came to stay, and the ice retreated farther and farther to the north. It still remained among the mountains, so that we might 


\section{COLD AND ICE ON THE EARTH}

describe the glaciers of the Alps and of the Canadian Rockies as the last relics existing to-day of the great Ice Age of the past. The retreat to the Arctic Circle left many other relics behind it, the great lakes, for example, like Winnipeg and Manitoba, and the Great Salt Lake of Utah. All were once mightier sheets, because during the Ice Age their waters were held back. Other smaller lakes formed by the dumping-heaps or terminal moraines of the glaciers still exist, and are especially noticeable in Finland. During the later stages of the Ice Age the level of the land was lower than it is now in Western Europe. When the ground began to rise-in slow upheavals with long pauses for rest-it left its impress in raised beaches, which can be seen on both sides of Scotland and on the Norwegian coast. The climate grew gradually milder, the animals and the plants followed in the train of the retreating ice, and even the traces of man's existence began to appear. The change was not sudden; it was so gradual that the Ice Age slipped as imperceptibly as its own glaciers into the age in which Man's activities in Europe began. 


\section{COLD AND ICE ON THE EARTH}

In North America there are similar traces of the great ice-sheet, one of the branches of which streamed southward into the basin of the Mississippi, the second moring westward from Hudson Bay to the Rockies, and southward to Iowa, and the third setting out from the great mountain ranges of British Columbia. Right across North America to-day for thousands of miles stretch accumulations and mounds of rock which were pushed forward by the ice, and were dropped by the glaciers when they reached "farthest south." These accumulations are called, from their origin, the great "terminal moraines" of the North American Ice Age.

It must not be thought that these great ice-sheets of both hemispheres remained constant in extent and thickness. 'There were periods of retreat and advance, of progress and shrinking, and the shrinkings of these took place on a large scale, and perhaps lasted for hundreds or thousands of years; so that mixed with the strata of boulder-clay, which are the characteristic strata of the glacial periods, are other strata of sind, ordinary clay, and even peat. Remains of plants and animals are found in these strata, showing that sometimes the glaciers retreated so far and for so long that regetation sprang up and animals lived on the ground that they had covered-in the intervals when the cold of centuries was replaced by other centuries of mild and eyuable climate.

At last, after many of there swallow-like retreats and advances, the warmer climate al lengrth came to stay, and the ice retreated farther and farther to the north. It still remained among the mountains, so that we might 


\section{COLD AND ICE ON THE EARTH}

describe the glaciers of the Alps and of the Canadian Rockies as the last relics existing to-day of the great Ice Age of the past. The retreat to the Arctic Circle left many other relics behind it, the great lakes, for example, like Winnipeg and Manitoba, and the Great Salt Lake of Utah. All were once mightier sheets, because during the Ice Age their waters were held back. Other smaller lakes formed by the dumping-heaps or terminal moraines of the glaciers still exist, and are especially noticeable in Finland. During the later stages of the Ice Age the level of the land was lower than it is now in Western Europe. When the ground began to rise-in slow upheavals with long pauses for rest-it left its impress in raised beaches, which can be seen on both sides of Scotland and on the Norwegian coast. The climate grew gradually milder, the animals and the plants followed in the train of the retreating ice, and even the traces of man's existence began to appear. The change was not sudden; it was so gradual that the Ice Age slipped as imperceptibly as its own glaciers into the age in which Man's activities in Europe began. 


\section{CHAPTER VII}

\section{THE FIRE-HARDENED ROCKS}

O far we have been considering the deposits laid $S$ down, for the most part, in a leisurely and orderly manner, by the action of air and water; by floods, rivers, lakes, the sea, or by the slow morements of ice. If these, however, had been the only agents by which the earth's strata were accumulated, then it is clear that for the most part these deposits and these strata would lie evenly, one on top of the other, like the lines of print on this page. But as a matter of observation the earth's strata do not lie like that. If we were to tear this page out and crumple it up in a ball, first having torn it in half and shredded a few irregular pieces out of it, we should get a truer picture of the way in which many of the earth's strata are contorted, crumpled, and displaced. They have not been so distorted by the action of the sea, violent as are some of the sea's assaults on the land; nor would the heat of the sun at its greatest ever produce such effects. They must have taken place from some causes which arise in the earth itself. These causes can be summed up in one word-fire. Some of the strata of which we have spoken, and which are called sedi- 


\section{THE FIRE-HARDENED ROCKS}

mentary strata, although they were composed of soft materials to begin with, have become very hard since, in some cases owing to the enormous pressure of the accumulated deposits above them, in other cases because of chemical action. In a few cases they have become hardened not so much by losing their water, as by direct heat. But the hardest of them is not so hard as another class of rocks with which we are all acquainted-rocks like granite, or quartz, or basalt. And it will be evident to any one who thinks about the subject for a moment that no amount of pressure would make a rock as hard as a diamond. Now how have these rocks been made? The answer is that they have been made in some interior furnace of heat deep down in the earth. Sometimes they have boiled up, and we can trace them bursting their way through the sedimentary strata above them. We do not know very much about the furnaces or cauldrons whence they have come; in fact, we know very little about the depths of the earth. 'The deepest mine-shaft known is near Lake Superier, and is only 5000 feet in depth. In Silesia a bore-hole has been made by the Austrian Government of a mile and a quarter in depth. It would be by no means an easy task to sink a great boring. 'The Hon. Charles Parsons has described some of the difficulties.

The shaft would have to be sunk in a neighbourhood where it would not be likely to encounter water on its way down, because otherwise there would be the necessity of pumping operations, In order to be of value for purposes of ohservation, the shaft would be of the size 


\section{THE FIRE-HARDENED ROCKS}

usual in ordinary mines and conl-pits. It would be sunk in stages each of about half a mile in depth, and at each stage there would be placed the hauling and other machinery for dealing with the next stage below. This machinery, in order to economise space and limit the heat of the workings, would be electrical. Even so there would have to be special arrangements for cooling; and the depth of each stage in the boring would be restricted to half a mile in order to avoid great cost in the hauling arrangements, great weight of rope, and the great cost of keeping the machinery and workings cool. At each second or third mile down there would be air-locks to prevent the air-pressure from becoming excessive, owing to the weight of the superincumbent air. For when we got between two and three miles down below the surface of the earth the atmospheric pressure there would be double what it is at the earth's surface, or, therefore, about thirty pounds to the square inch. It would not be easy to work under greater air-pressure than that, firstly because of the strain on the workmen, and secondly because of the rise of temperature which this increased air-pressure would cause. Therefore special chambers would have to be constructed to relieve the pressure, as well as special pumps to provide rentilation, and other machinery to carry the superfluous heat to the surface. This last-named machinery would be of the nature of brine-filled pipes, in which a freezing mixture would always be kept circulating. (The arrangements sugrgested by Mr. Parsons for keeping the underground workings cool are rather too complicated for description here; but 


\section{THE FIRE-HARDENED ROCKS}

no doubt the means he suggests would be effective, and it would be possible, though with great difficulty, to keep the workings cool.)

When the borings extended to a depth of some miles it would be necessary to freeze the bottom of the shaft. This is a thing which is sometimes now done when a shaft is being sunk through quicksands that may be encountered on its way down. Round the circle of the main shaft a number of small bore-holes are driven, and into them is poured very cold brine, which freezes the material through which the shaft is to be driven. In the case of the great boring we are considering this would have to be done not only at the bottom of the shaft but also for some time on the newly pierced shaft sides, until the surrounding rock has been cooled for some distance from the face.

What would such a shaft cost? How long would it take to build ? What would the temperature be that it encountered on the way down? The following is the estimate offered by Mr. Parsons :-

Cost Time in Temperature

$£$ Years of Rock

For 2 miles depth from the surface $500,000 \quad 10 \quad 122^{\circ} \mathrm{F}$.

\begin{tabular}{|c|c|c|c|c|c|c|}
\hline, 4 & " & " & " & $1,100,000$ & 25 & $152^{\circ}$ \\
\hline,$" 6$ & ", & , & ", & $1,800,000$ & 40 & $182^{3}$ \\
\hline 8 & , & ", & , & $2,700,000$ & 55 & $212^{\circ}$ \\
\hline 10 & , & , & , & $3,700,000$ & 70 & $212^{\circ}$ \\
\hline 12 & ," & ," & , & $5,000,000$ & 85 & $272^{\circ}$ \\
\hline
\end{tabular}

But this estimate does not include the cost of cooling the shaft or of providing it with air-locks. Mr. Parsons in delineating the scheme remarked on the rast amount of 


\section{THE FIRE-HARDENED ROCKS}

information with which such a boring would furnish engineers, miners, and geologists; but the point that we wish to make is that even with this enormous expenditure of time, industry, and money we should be as far as ever from knowing anything about the core of the earth. We should have only gone about a third of the way through what geologists call the earth's crust.

Here, again, we are in a condition of difficulty. How thick is the earth's crust? and what is there beneath it? Well, as we are still such a long way from exploring it we can only give a rather doubtful answer; and we must therefore try to show not only what is thought about the earth's interior but why we think it. From Mr. Charles Parsons' table it will be seen that he calculates that as the boring went deeper it would find a higher and higher temperature among the rocks. At two miles down it would be hotter than the hottest summer's day at the earth's surface; at eight miles down water would boil by itself; at twelve miles down, unless the cooling arrangements were extremely good, the workmen would die like flies. How does Mr. Parsons know that there would be these temperatures, seeing that the deepest boring hitherto made is only a mile? He bases his calculations on what we know already of the ascending temperature at deepening levels.

For ten years Professor Agassiz took observations concerning a very deep mine in the United States called the Calumet and Hecla Mine. He and Professor Chamberlin, after examining all the observations very carefully, came to the conclusion that in going down from the earth's 


\section{THE FIRE-HARDENED ROCKS}

surface the temperature rose at a rate of about $1^{\circ}$ of heat (Fahrenheit) for every 125 feet.

At the North Garden Gully Mine, Bendigo, Australia, and at the New Chum Mine a temperature of $99^{\circ} \mathrm{F}$. was reached at 3000 feet, and $107^{\circ}$ at 3645 feet. The rate of increase of temperature was reckoned to be $1^{\circ}$ of heat (Fahrenheit) for every 80 feet.

This rate of $1^{\circ}$ for 80 feet was also found at a South German mine, Maldon, as well as at a Ballarat mine, and at a mine near Port Jackson.

In a French mine more than 3000 feet deep, at the collieries of Ronchamp, the rate of increase was as high as $1^{\circ}$ in 50 feet.

In the North Staffordshire mines Mr. Atkinson, H.M. Inspector of Mines, found the increase to be on the average $1^{\circ}$ in 65 feet; whereas in the South Staffordshire Hamstead Colliery Mr. F. G. Meachem found that the increase was $1^{\circ} \mathrm{F}$. for every 110 feet. The same rate was obtained at the Baggeridge Wood Colliery, South Staffordshire.

In South Wales, in the neighbourhood of Rhondda and Aberdare, the rate is $1^{\circ}$ for 95 feet; at Dowlais, in the Merthyr coalfield, it was $1^{\circ}$ in 93 feet; at the Niddrie Collieries, near Edinburgh, the increase is at the rate of $1^{\circ}$ in 99 feet.

It will thus be seen that all over the world there is an increase of temperature at a rate which, on the average, is about $1^{\circ}$ for every 100 feet. There are 5280 feet in a mile; therefore, if this rate of increasing temperature were maintained, at a depth of 100 miles the temperature 


\section{THE FIRE-HARDENED ROCKS}

would be perhaps 5000 F.; it temperature at which steel would melt and boil away into vilpour. At a depth of 200 miles the heat would be greater than that of the surface of the sum. ${ }^{1}$

Now at temperatures like that everything we know on the surfice of the earth would melt. Something else would happen to it besides that. 'Those of our reader's who have ever seen experiments at the Royal Institution in London by Sir James Dewar or Sir William Crookes will know that if metals are made hot enough they will not only melt but will boil away into vapour as water boils into steam. And perhaps we need tell no one that air, if it be subjected to a low enough temperature, can be made a solid like ice. In fact, everything in nature, whether we generally know it as a solid (like iron), or a liquid (like water), or a gas (like air), can be made to assume either of the two other forms. Thus the solid iron ean be turned into a liquid or a gas, and the liquid water can be turned into a gas by boiling, or into ice by freezing. The gaseous air can be turned into a liquid by lowering its temperature to some $300^{\circ} \mathrm{F}$. or more below the point at which water turns into ice; while if we lower the temperature to about $390 \mathrm{~F}$. below freezing, it will turn into a solid. At a temperature of about $490^{\circ} \mathrm{F}$. below freezing everything in nature, whether gaseous or liquid, would become a solid, and that temperature, which is the lowest that can possibly exist,

1 According to the calculations made by the late Mr. W. E. Wilson, r.n.s., in Ireland, $5753^{\circ}$ Centigrade ahore the lowest lemperature which is possible in space, or about $10,500^{\circ} \mathrm{F}$. 


\section{THE FIRE-HARDENED ROCKS}

is called Absolute Zero. But just as every gas becomes a solid at that temperature, so there are temperatures at which every solid becomes a gas. Gold, for instance, begins to be a liquid at about $1900^{\circ} \mathrm{F}$., and if we heat it to $2000^{\circ}$ it will become a gas.

Therefore it will be seen that if we were to suppose that the earth grew steadily hotter all the way down to its centre, we should comparatively soon come to a point when everything would be trying to turn into a gas. But there is one other thing to be thought of. Imagine what the pressure of the weight of the rocks themselves must be. At a depth of a mile pressure from above arising from the weight of the overlying rock is about $6000 \mathrm{lb}$. to the square inch. At three miles the weight has increased to $18,000 \mathrm{lb}$, at four miles to about $24,000 \mathrm{lb}$., and at five miles to about $30,000 \mathrm{lb}$. to the square inch. Now the average strength required to crush rocks has been shown to be about $25,000 \mathrm{lb}$. to the square inch for granite, for limestones about $16,000 \mathrm{lb}$. to the square inch, and for the sandstones about $6000 \mathrm{lb}$. to the square inch. At a depth of five miles, therefore, the weight above must be equal if not greater than the resisting power of the rock. What will happen lower than that? An experiment shown some years ago by Sir William Roberts Austen at the Royal Institution gives us some idea of what might happen. He subjected iron to very great hydraulic pressure, and he arranged the experiment in such a way that the spectators could see an image of what was happening projected by a beam of light on to a kind of magiclantern screen. The iron began to move like slowly melt- 


\section{THE FIRE-HARDENED ROCKS}

ing pitch, or very thick gum. In fact, at depths of about six, seven, or eight miles, it is supposed by many geologists that if the lower rocks had room to more they would have a tendency to flow. ${ }^{1}$

Suppose, however, they cannot flow, that there is no room for them to flow, and that the pressure is not merely thirteen or fifteen tons to the square inch, as it would be at depths between five and six miles, but a hundred times that amount, as it might be between five and six hundred miles down. What would happen then? We can only imagine what does happen by stating what does not happen. It used to be supposed as late as half a century ago that the earth consisted of a crust of hard rocks perhaps thirty to fifty miles in thickness, and that below this crust the whole earth was a mass of red-hot or whitehot molten stuff with flaming gases mixed with it. If that were the case it would explain a good deal of what we see around us. It would explain the volcanoes, for instance, which belch out fire and lava and ashes and molten rock, and sometimes great fragments of rock. Perhaps some of our readers may remember the great cruption of Mount Pclée, which took place in Martinique some years ago. At one stage of the eruption a great obelisk of rock a thousand feet high was pushed upwards out of the crater, and eventually sank back again. It came out of the depths of the earth. It was like a ventpeg plugging some boiling mass below. Similarly we might suppose that all voleanoes were vent-holes for the tremendous commotion of boiling fiery rocks below the Giolugy! : Earth IIistory, p. 127. Chamberlin and Salisbury: 


\section{THE FIRE-HARDENED ROCKS}

earth's surface. The only thing we can urge is that they do not seem big enough for the purpose, if the earth were indeed all molten except for a thin crust-thirty miles thick. For that would leave a molten ocean more than 7900 miles across any way it was measured: 7900 miles deep, 7900 miles broad, 7900 miles long, if we take the diameter of the earth to be 8000 miles. We all know what great tides the Moon and Sun by their attraction raise in the earth's outer ocean of water. Think what tides they would raise in this inner ocean of molten rock and metal. The earth's crust would not be able to hold such tides in. The molten stuff would be always breaking through the flimsy thirty miles of outer solid rock as if it were egg-shell. Twice a day there would be outbreaks of lava vast enough to submerge continents.

No, that will not do. We will not confuse our readers by telling them all the theories that have been formed, but will only state what the late Lord Kelvin believed, and most of the present generation of geologists believe. It is that the heat of the earth's crust continues to increase only for a certain distance of the way down, and that owing to pressure the earth is solid (though very hot except towards the surface) for two thousand miles down. There remains a thickness of another four thousand miles on either side of the earth's centre to be considered. That might be molten, but the pressure would be so great that it would behave as if it were a solid. We know the earth cannot be solid all through because it does not weigh enough. 'The earth cannot, of course, be weighed in any scales, but there are methods of weighing it nerer- 


\section{THE FIRE-HARIDENED ROCKS}

theless. One of two methods is by seeing how strongly it attracts bodies to itself. But these things belong rather to the romance of astronomy than to that of geology. We need only trouble ourselves at present about the results.

One word more about the deep interior of the earth. Dr. J. J. See, an American astronomer, has found how heary and how hard the earth is, taken as a whole. He finds that if it were built from surface to surface of hardened steel it would be just about as heary and as hard-or as rigid. The steel would be like that used for the armour-plate of battleships. Dr. See is not prepared, however, to discard the idea that the earth has a large fluid interior. If it were fluid, yet it would be subjected to such enormous pressure by its own weight, that if there were a moderately thick earth-erust, it: tidal surgings would be so "cabin'd, cribbed, confined," that they would be comparatively ineffectual. We must not run away with the idea (argainst which Dr. See specially warns us), that there is any free circulation of currents within the fluid interior. 'The rigidity produced by pressure (or weight) is too great for that. Indecd, this pressure is so great that, ats another scientific authority, Professor Arhenius, has pointed out, the matter at the core of the earth might even be gaseous; and yet would be so compressed by pressure that it would possess a rigrity equal to the hardest steel. The auth may be partly solid, partly liquid, partly gaseous, but for all practical purposes Professor See would have us regard it as a solid sphere having an average hard- 


\section{THE FIRE-HARDENED ROCKS}

ness and weight and "rigidity" greater than that of ordinary steel.

We are still some way off an explanation of how the many igneous rocks which were and are being "boiled up" in some inner molten cauldron came to the surface; but the better to understand that we must ask our readers to carry their imagination back to the very beginning of the world when it was "without form and void." 


\section{CHAPTER VIII}

\section{THE EAR'TH AT I'TS BEGINNING}

$I^{\prime}$

F we look up at the sky with the eye of knowledge we can read in the celestial objects with which it is strewn something of the history of our earth. We can only read it dimly even with the aid of the greatest telescopes, and it is quite possible that in some respects we may read it wrongly. Let us, however, consider what the eye and the telescope will reveal to us. The ere will see the Sun-a great ball, into which the earth might sink without greatly altering the Sun's appearance, and surrounded with flaming gases hotter than the hottest furnace man has ever been able to contrive. In that heat every solid thing on the earth would melt and be turned into vapour. The eye will also perceive the Moonanother ball, much smaller than the earth, surrounded by no gases at all, having as far as can be seen no water; and being so cold during its long nights that all gases and liquids of which we know would be frozen solid there.

The eye can also see a myriad of stars of varying brightness, but for the most part only thus distinguishable. If the telescope be now called in to aid, the eye will, however, be able to discern differences and distinc- 


\section{THE EARTH AT I'TS BEGINNING}

tions in the stars. It will see that some are balls like the Earth, the Sun, and the Moon. If these balls are studied attentively we shall discover that one of them, Jupiter, is a great deal hotter than the earth, though a great deal cooler than the Sun; and that another of them, Mars, is a great deal colder than the earth, but a great deal warmer than the Moon. Perhaps we might now begin to surmise that the Sun coming first, Jupiter next, the Earth next, Mars next, and the Moon last, were all like stages in the history of one of these balls; and that, for example, any one ball began by being as hot as the Sun, and ended, after passing through stages like Jupiter, the Earth, and Mars, in being as cold and lifeless as the Moon.

But if one had a very good telescope, and could examine those more distant specks of light which we call stars, we perhaps could spy a little earlier into the history of these great balls. For example, among the blazing lights of the heavens - the stars which we know to be suns-there are others which are not balls at all. There are the Pleiades, for instance, of whom the Prophet Amos wrote, "Seek IIim that maketh the seren stars and Orion "(Amos v. 8). The seven stars (in the Authorised Version rendered Pleiades), ${ }^{1}$ when seen through a great telescope, are caught in a mesh or a veil of something that may be starry matter, but of the exact nature of

'It has been cogently suggested that by the "seven stars" the biblical writer meant the constellation of the Great Bear; but Mr. E. W. Maunder, F.n.A.s., of Greenwich Observatory, is of opinion that the Pleiades were signified. 


\section{THE EARTH AT ITS BEGINNING}

which we are uncertain. In other parts of the sky there are great masses of this starry mist; and to these bright patches astronomers have given the name of "nebulae." The most wonderful of them all is the great nebula in Orion $;^{1}$ and one of the most beautiful is the great spiral nebula of Andromeda. These objects are not only wonderful and beautiful; they also give us a hint as to what might have been the earliest state of our earth, and of the Sun itself in those almost inconceivably distant agres before order took the place of chaos.

Let us ask the reader to imagine what would take place if the earth were to come into collision with another planet. Some of our readers, at any rate, will know that the Sun and all its planets-the earth among them-is moving swiftly to some unknown destination among the stars. $^{2}$ Suppose that some great planet, not of the Solar System, barred our path. We should not be taken wholly unawares, for astronomers would know of the approach of the star and our earth to one another months, and perhaps years, beforehand. That would be because the light of the Sun falling on it would be reflected, just as the reflection of the Sun's rays light up the Moon for our eyes. If the strange planet were a very large body, like the sun for bigness, it would become visible far beyond the confines of the Solar System. It might first be taken for a new star such as sometimes blazes up in the sky and

1 "God maketh Arcturus, Orion, and I'leiades, and the chambers of the south" (Job Ix.9).

"It is usually supposed that this movement, amounting to perhaps ten miles a second, is in the direction of the constellation of Vega. 


\section{THE EARTH AT ITS BEGINNING}

then sinks into darkness again. But its steadiness would make it an object of suspicion. There would be another brief period in which it might be taken for a comet; but comets have a light quite different from that of reflected sunlight. So that anxious expectation would be dissipated, and the world would begin to recognise the monster for what it really was. If its size were the same as that of the Sun, then it would first become visible to us when $15,000,000,000$ miles distant, ${ }^{1}$ or let us say 1600 times farther away from us than we are from the Sun. We and it would approach slowly at first. It would be nearly ten years before the distance had been reduced to $6,000,000,000$ of miles, and the intruder had begun to be visible to the naked eye. In fourteen years it would have reached the outer edge of the Solar System, and would be the brightest star in the heavens. In another year it would be twice as bright as Venus at her brightest, and would be coming nearer with appalling swiftness. In less than two months it would be as near the Sun as we are. In a week more it would have plunged into the Sun at the rate of 400 miles a second, and in the awful heat born in that collision, Sun and earth and planets would be molten, and the Solar System overwhelmed

In uuremorseful folds of rolling fire.

Suppose that this catastrophe were to take place. Would that be the end of all things? No. Out of the fiery mist many millions of miles across-like one of those

${ }^{1}$ See an article by Mr. Ellard Gore in Knovledge, November, 1905. The object would not be visible at this distance except through large telescopes. 


\section{THE EARTH AT ITS BEGINNING}

great nebula which the telescopes reveal to us-order would be erolved. 'Two things would at once begin to happen, since in the Universe nothing stands still. The fiery mist would be giving out heat all about it, sending out heat-waves as a fire or a red-hot poker will do. The red-hot poker cools; so, too, would the fiery nebula. Then the nebula would begin to condense; not quite in the same way that a cloud of steam does, for it would be whirling all the time, and its fiery particles would be all trying to fall inwards, just as anything dropped from our hands tends to fall towards the centre of the earth. As this whirling mass of gas condensed some great masses of it would become detached, and would begin to enjoy separate existences of their own.

Let us imagine, for the sake of argument, that a mass of gas vast enough, when it condensed, to form the earth itself became detached from the parent nebula. Suppose we follow its history. At first it may have been a globe hardly distinguishable from a whirling flame. In brightness it was like the Sun, and like the Sun, it was covered with elemental gases. It was, in fact, in its earliest days a sphere of gas continually giving out heat, and continually cooling, till from a sphere like the Sun it became a ball like Jupiter. It had an intermediate stage when its gases were condensing into liquids, as steam condenses into water ; for though the nebula as a whole was hot it was always travelling through cold space. Gradually the earth became partly liquid and partly gas. For millions of years it continued to revolve as a ball of licquid-still 


\section{THE EARTH A'T ITS BEGINNING}

cooling-still being pressed very hard at its central parts by the weight of all the gases and liquids round it, till at last the first crust of solid matter began to form on the liquid surface. This crust continued to thicken, but it was subject to many appalling catastrophes and breakages.

We have already used the occurrence of the tides of the earth as an instance of the Sun's attraction. The Sun (and the Moon) attract the waters of the earth, pulling them up towards themselves. So would they also attract the molten materials of which the early earth was composed. The liquid mass would be continually surging like a tide against its wall of solid crust, and the liquid would now and again burst through. There must have been a time when the thin solid crust covering the molten interior became, owing to the solidification and contraction of the crust, much too small to contain the liquid material. The lava would then break through, and would form huge craters, not unlike some of those which we see on the Moon. We can faintly imagine these terrible outbreaks in which the molten tide rose not thirty or forty feet but many miles high !

Later, after some relief had been given by these outbreaks and the crust thickened, the interior regions of the earth by cooling shrank away from the solid shell, which was now too large. This solid shell being insufficiently supported sometimes caved in, and other great outflows of lava resulted. These lava floods dissolved the original solid shell whenever they came in contact with it. The earth probably once had gigantic craters like those which 


\section{THE EAR'TH A'T I'TS BEGINNING}

we can see in their cxtinct form on the Moon; but they were destroyed by these outhlows of lava of which we have spoken.

'Then, still cooling, the earth's crust grew thicker and thicker. The great outflows and eruptions of molten elements from underneath grew fewer, and more liquid elements cooled into solids, and more gases condensed into liquids. There was another thing happening of which, as conscientious recorders of the history of the earth's geology, we must take note; and it is that in those early days meteorites were falling on the earth in rastly greater numbers than they do to-day. Meteorites are masses of cooled rock flying through space which still occasionally fall on the earth, and specimens of them are still to be found, many of them preserved in museums, such as the Natural History Museum in Cromwell Road, London. But the earth in its path has swept most of them up, as the housemaid's dusting-pan collects the fragments of dust. When the earth was young there were incomparably more fragments to collect, and they fell on the earth like rain.

Meanwhile the cooling water vapour became the oceans; clouds and rain and cool winds and eventually snow and ice became possible; and the hardening lavas, or fire-born rocks, became subject to their influences, till above them were raised the stratified rocks, of which we have spoken in our earlier chapters, and the lineage and descent of which is part of the study of geology. On the earth most of the traces of its earlier history have been removed, but there are some signs of them perceptible to 


\section{THE EARTH AT ITS BEGINNING}

the comprehending eye. The earth is probably seamed with great cracks that do not now reach to the surface, but which are indicated by the presence of chains of volcanoes. The volcanoes of the great chains of the Andes lie along a straight crack reaching from Southern Peru to Terra del Fuego, 2500 miles in length. The volcanoes of the Aleutian Islands lie along a curved track equally long. Other shorter lines of volcanoes are very numerous, and since countless others existed in former times, the cracks in the earth's crust must be exceedingly numerous. There is one crack which comes to the surface in various places in Eastern Asia and Western Africa, and stretching from the Dead Sea to Lake Nyassa, reaches the enormous length of 3500 miles.

From this brief sketch of the formation of the earth, its progress and processes, and from the hints which the volcanoes and earthquakes of to-day afford us, we may obtain some idea of the underworld that lies far beneath our feet. Not much, however, for we are ignorant of the actual conditions which exist towards the centre of the earth. But there seems a strong case for supposing that there is an outer solid crust of earth and an inner molten core of very great heat. 


\section{CHAPTER IX}

\section{THE CHILDHOOD OF THE EAR'TH}

E'T us now sum up the various stages in the early growth of the earth, as most geologists believe them to have occurred.

The first stage was that when the earth, shining like a star, existed as a flud globe surrounded by heavy vapours of great thickness, which contained the future waters of the globe.

Then began the second era of the earth's existence, when it was a hot solid globe-solid at any rate at the surface, and with a temperature of about $2500^{\circ} \mathrm{I}$. The globe's atmosphere still contained all the waters of the earth. It contained all the carbonic acid gas which now exists in the limestones and in coal and other minerals containing carbon. It contained also all the oxygen since shut up in the rocks and in regetation and in animal substances. Such an atmosphere was probably at least two hundred times as great as the atmosphere which now surrounds the earth.

Then followed an epoch when great rolcanic action set in. We have partially described it already. Just 


\section{THE CHILDHOOD OF THE EARTH}

a thin solid crust was all that covered the molten interior of the globe. It was too thin always to contain the boiling liquid, and Titanic explosions, followed by enormous overflows of lava, continually broke up the crust. The pressure was relieved by these explosions, and gradually the earth would settle down again to its process of consolidation. Another explosion would follow; again a great flow of lava; and again the effects of the catastrophe would subside. After each explosion and outflow the earth's crust would grow a little thicker. All this time, and for long succeeding ages, the earth was attracting to itself, as a magnet attracts iron filings, all the small bodies which it encountered on its path round the Sun. These little rocks or masses of matter, some great and some small, would each add something to the size of the earth, and, by the shock of collision with it, something to the earth's heat-just as a bullet flattening itself against a target melts in the heat of collision. Just also as the bits of matter which we call "shooting-stars" are set on fire by friction as they rush into the earth's atmosphere. These meteorites, as they are called when they are comparatively small bodies, or "planetismals," as they are called when they are large, still exist. But the earth, in the millions on millions of years which it has been coursing round the Sun, has swept up all the large ones that are likely to fall into it, and there remain only the small ones which occasionally cross its path. These are called "Leonids" or "Lvrids" or "Perseids," and these meteor showers occur at nearly the same time every year when the 


\section{THE CHILDHOOD OF THF EARTH}

earth runs through a swarm of them on its pathway round the Sun. But they are very small. Some of them are no bigger than a slate pencil. Few are as big as brickbats, and nearly all are burnt up by the air-friction before they reach the earth's surface. Larger ones still fall on the earth, however, and it is calculated that many hundreds reach us in fragments every year. But when the earth was young many thousands fell every day.

To this era, or immediately before it, belongs the birth of the Moon. It is a subject of interest to geologists, because it is admitted that the materials of which the Moon is constituted are similar to those of the earth: and it is believed that its history up to a certain point was very like that of the earth. It had its great volcanic era such as we have described; but its development closed shortly afterwards. WVe are considuring, however, at this moment its origin. It was once part of the earth. All of us have read of those little animals, of which one form is the amoba and another form the white corpuscles of the blood. If we watch them under the microscope we may see one of them slowly lengthen out, then break in two, and each part go swimming away by itself, a perfect animal. It was Sir G. H. Darwin, F.r.s., who proved mathematically in 1879 that the origin of the Moon was such that we may properly compare it to the splitting up of the little animals just described. The date of this event cannot be fixed even approximately - beyond saying that as astronomical events go it must have been 


\section{THE CHILDHOOD OF THE EARTH}

rather recent, though not less than fifty million years ago. The Moon is therefore one of the younger members of the Solar System. But no other catastrophe, either before or since, has occurred on the earth to compare with its prodigious birth. Five thousand million cubic miles of material left the earth's surface never again to return to it. Whether it all left at once or whether the action was prolonged we do not know, but we may try in vain to imagine the awful uproar and fearful volcanic phenomena exhibited when a planet was cleft in twain and a new moon was born into the Solar System.

Then, life still being absent from the earth, the Occanic Era began. The waters condensed into an ocean over the earth, or else collected in some great oceanic depression. Lands presently emerged from it. It was a hot ocean, steaming no doubt, for its temperature was perhaps about $500^{\circ} \mathrm{F}$. Some one may ask-Why, then, did it not steam away into clouds? The answer is that the atmosphere was still very heavy in that past era, probably still exerting a pressure as much as fifty times as great as to-day. The pressure of the atmosphere at the earth's surface to-day is usually about fifteen pounds to the square inch. In such circumstances water boils rapidly away at the temperature of $212^{\circ} \mathrm{F}$. But if the water be taken up to the top of Mont Blanc, where the air pressure is less than that at the sea-level (or if, which amounts to the same thing, we reduce the pressure on the water's surface by placing it under the receiver of an air-pump and partially ex- 


\section{THE CHILDHOOD OF THE EARTH}

haust the air), it will boil at a lower temperature than this. If, on the other hand, we increase the pressure on the surface of the water by any means, such, for example, as by placing it in a chamber of compressed air, the water can be heated to a higher temperature without boiling away. In the bygone era of which we are speaking the pressure of the atmosphere on the water's surface was $700 \mathrm{lb}$. or $800 \mathrm{lb}$. to the square inch: and therefore it could be heated up to a high temperature without evaporating rapidly.

Another thing began to happen in those days. All bodies in space attract one another; the Sun attracts its planets; the planets attract the Sun and their satellites; and the satellites in their turn attract the planets. Ages before the earth had a moon these forces were at work. But the attractions of solid bodies for one another do not bring about any very perceptible alterations in their shapes; though if the bodies are spinning they effect slow changes in their speed of rotation. It is different when the bodies are liquid, or if they have liquid surfaces. Then the attractions of a sun or a moon on a planet begin to draw up the waters of the planet and produce tides. 'The attraction of the earth would produce tides on the Moon if an ocean existed there; and, it is suspected, do produce something resembling tides on the present surface of the Sun. ${ }^{1}$ As soon, therefore, as oceans appeared on the earth the

1 A paper read by Mr. E. W. Maunder before the Royal Astronomical Society in 1907 gave reasons for believing that the earth has perceptible effects on the movements of sun-spots. 


\section{THE CHILDHOOD OF 'THE EAR'TH}

waters began to ebb and flow in tides. (Another consequence of this constant ebb and flow was that the friction of these movements began to diminish the speed of the earth's rotation-just as a string that was placed round the circumference of a spinning-top would, if constantly pulled backwards and forwards, gradually help to slow down the top.) Then oceanic waves and currents would begin to eat a way into the land that was on their borders, or which was emerging from their depths. Rivers would begin to arise, and they would carry on the work of erosion. Other causes tending to break up the rocks would be the gases in the air-the excessive quantities of carbonic acid and oxygen would be active chemical agents in this work. Before the close of this era the limestones and iron carbonates began to form; sediments arose in the lifeless oceans, and thus began the first formation of those sedimentary rocks and strata which have been dealt with in the earlier chapters.

After the lifeless era began the age when the lowest forms of life came into existence. The initial stage was perhaps the Era of the First Plants, Algr, and later still aquatic fungi or bacteria. This began when the general temperature of the ocean may have been as high as $150^{\circ} \mathrm{F}$. (some water plants can now live in waters up to and above $180^{\circ} \mathrm{F}$.). Limestones began to form from the secretions of plants, and deposits of silica from silica secretions. Also where the conditions were farourable there were large sedimentary deposits and accumulations. In the second part of this æon the earth, still continuing 


\section{THE CHILDHOOD OF 'THE EAR'TH}

to cool, and going down in temperature to $115^{\circ}$, gave opportunity to animal life. At the end of this era the general temperature of the earth and its oceans was as low as $90^{\circ} \mathrm{F}$. The first animal life had begun to appear; its activity greatly increased under what were favourable conditions for it. This increase of animal life had its effect on the earth's crust. We have already spoken of the formation of limestones from the bodies of sea animals. This was going on in those ages millions of years ago before any of the higher forms of life had appeared on the earth, and though it was not going on so rapidly, still it must be remembered that at some point of the world's history the oceans were of greater extent than now, and consequently the deposits of lime and the accumulations of sediment were more widespread. The sedimentary rocks grew faster and faster, especially on the floors of the oceans.

It will be understood by those who have read the foregoing two chapters closely that the "igneous" or fire-born rocks must lie underneath the sedimentary ones. But that is only true in general terms, for a double reason. In the first place, owing to the inestimable forces which for millions of years were still continually effective below the earth's crust, the igneous rocks over and over again were able to burst their way through the slow-forming sediment of other rocks laid down above them. In the second place, the igneous rocks, owing to their composition and superior hardness, were much less worn by wind and weather than the less compact "sedimentary rocks," and these remained, showing 


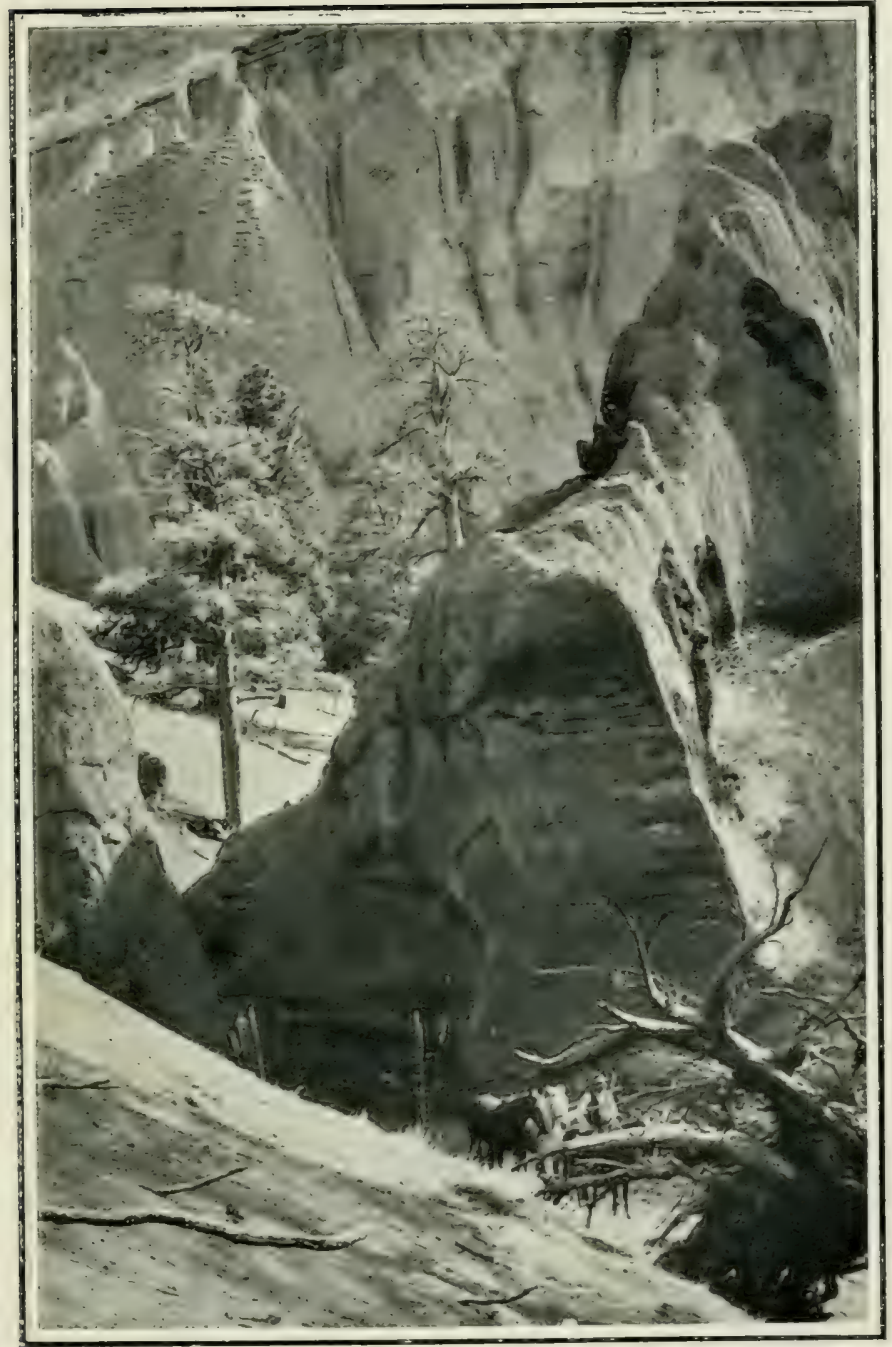

sereo cosprishe. lindersuod is l:

Iondon and liew lor

THF CRATER OF AN EXTINCT Volcano

This is the entrance to the long extinct volcano of Red Mountain, Arizuna. 



\section{'THE CHILDHOOD OF THE EAR'TH}

themselves at the surface as coast-lines of oceans and in mountain ranges, after the sandstones and shales and limestones had disappeared.

The memorials of volcanic action remain, we had almost said permanently, among the decay of other rocks, though, of course, even hard volcanic or igneous rocks will be worn down in time. In many cases volcanoes themselves are left, though they may have been for ages extinct. In some volcanic regions where no great central cones have existed the vast floods of lava that were poured forth extend to-day as vast black plains of naked rock, mottled with shifting sandhills, or as undulating tablelands carved by running water into valleys and ravines, between which the successive sheets of lava are exposed in terraced hills. Beyond the limits over which the lava sheets have spread there are often great veins or parapets or sunken walls of lava to which are given the names of igneous or volcanic "dykes." Dykes vary from less than a foot to one hundred feet in breadth, and often run in nearly straight ccurses sometimes for many miles. They consist usually of very hard rock like basalt, "andesite," or "diabase."

They were fissures in the earth's surface, and, after the manner we have described, the molten rock welled forth through these fissures, and spread out sheet after sheet, till like a rising lake it has not only orerflowed the lewer grounds but even buried all the minor hills.

Lava eruptions of this kind have taken place in recent years in Iceland. On a small scale they can be seen to take place in the island of Hawaii, where the outflows of 


\section{THE CHIIDHUOD OF 'THE EAR'TH}

lava reproduce for us, like models in miniature, the great outbreaks of the past. On the largest possible scale similar effects may be seen on the great lava plains of the Moon, where the giant craters that we can see through telescopes are not the mouths of extinct volcanoes, but the banked-up edges and shores of lava outflows.

On a nuch smaller scale than this, but still on a gigantic scale, the same thing took place in Western North America, where there are vast tracts of land which are best to be explained by supposing that there were once great outbrealis and overflows. The area which has there been flooded with lava has been estimated to be larger than that of France and Great Britain put together, and the depth of the total mass erupted reaches in some plitees as much as 3700 feet. Some rivers have cut gorges in this plain of lava, laying bare its component rocks to a depth of 700 feet or more. Along the walls of thene ravines we see that the lava is arranged in parallel beds or sheets often not more than ten or twenty feet thick, each of which, of course, represents a separate outpouring of molten rock.

These are comparatively modern lava plains, although, of course, the outpourings in North America occurred ages before historic time, or, indeed, before there are any traces of man's existence on the earth. Such lava outflows can only occasionally be examined-as in the instance just quoted when rivers have cut deep into them. Consequently we have to speculate on the connection between the dykes and fissures and the lava flood itself. But in various parts of the world lava plains of much 


\section{THE CHILDHOOD OF THE EAR'TH}

older date have been so eaten into and worn by the action of the elements that not only the successive sheets of lava are exposed but the rock floor over which they poured. Exposed also are the abundant dykes which served as the channels by which the lava rose to the surface. In Western Europe important examples of this structure occur from the north of Iceland through the inner Hebrides and the Faroe Islands to Iceland. This volcanic belt presents a succession of lava sheets, which even yet, in spite of enormous waste, are in some places more than 3000 feet thick. These sheets are nearly flat and rise in terraces over one another into green grassy hills or into the dark fronts of lofty sea-washed precipices. Where sheets have been stripped off or worn down by wind and weather thousands of volcanic dykes are exposed. These dykes are, as it were, the roots of which the lava sheets were the branches; and even where the whole of the material that gushed up to the surface has been worn away the dykes remain as evidence of the vigour and energy of the volcanic forces. 


\section{CHAPTER X}

\section{'THE EAR'TH AS THE ABODE OF LIFE}

$\mathrm{N}$ the last chapter we spoke of the formation of the atmosphere of the earth and of the growth of the oceans. IVe must now consider the formation of these more closely, and we must distinguish between the great vaporous clouds which rolled about the earth in its molten state and the settled atmosphere which formed about it when it grew cooler.

After the carth had begun to solidify it was at first covered with a collection of porous fragments of rock covering the earth like a shell and containing the elements of water. Such materials in general appearance would be not unlike the pumice stone which is expelled from volcanoes to-day. Those who have never had the fortune to see volcanic eruptions for themselves usually imagine that the volcano throws out nothing but fire and smoke. As a matter of fact it throws out vast quantities of vapour, of which, according to Sir Archibald Geikie, 999 parts in 1000 are steam. At the great cruption of Mount Pelce the cloud of steam continually arising from the volcano for months in succession was several cubic 108 


\section{THE EARTH THE ABODE OF LIFE}

miles in measurement. Consequently it will be seen that the porous volcanic rocks with which the young earth was covered contained all the materials for water-manufacture within themselves. As the water began to form, squeezed out of the porous rocks as we can squeeze it out of a sponge (or as we might steam it out if we put the moist sponge in an oven), it gathered itself into reservoirs underground. As it increased in bulk it rose nearer to the surface; because, of course, owing to the heat of the inner portions of the earth it could never succeed in sinking below a certain depth. Doubtless it first appeared at the bottom of the pits which had been sunk by volcanoes or volcanic action. There must have been innumerable depressions in the earth's surface as widespread and deeper than those which we can perceive on the rugged surface of the Moon. We may gain an idea on a very minute scale of what the first pits of water were like from the examples (formed, however, at a much later period and probably in a different way) of the crater lakes that are left to-day. Some curious examples of "crater lakes" are to be found in the Eifel district of Germany, an ancient volcanic region which lies in the triangle formed by the junction of the Rhine and the Moselle at Coblenz. One of the pleasing peculiarities of this district is that, owing to the volcanic nature of the soil, the neighbourhood is seldom dusty, even in August or September, after the dry continental summer. It is well worth visiting for its castles as well as for its crater lakes and other volcanic relics, and it is the scene of R. L. Stevenson's romance Prince Otto. The chief crater 


\section{THE EARTH THE ABODE OF LIFE}

lakes are between Daun and Manderscheid. There are, of course, many other and larger crater lakes in existence, but we select these because they are so easily accessible.

The flow of the lakes into one another followed. Innumerable lakelets developed into rivers or chains of lakes on the surface of the young planet, continually becoming larger bodies of water, till they developed into the vast irregular oceans of to-day. This evolution is of great importance from a geological point of riew, because it leads the way to the origin of the ocean basins and the great platforms of land which we call continents. It is easy to see that because of the weight of water in the depressions the earth under the waters tended to become more and nore depressed, so that the water areas tended to grow larger and deeper. The wash of earths from the land tended to build its borders out into the water basins, but the deepening and spreading of the water basins is believed to have been the most marked feature of the earth's carly growth. All this time the earth was growing in diameter and circumference. ${ }^{1}$ When this growth ceased other causes and effects came into play, and the proportions of sea and land became better balanced.

There is nothing in our human knowledge to tell us with certainty when or how life first appeared on the earth. We have already spoken of animal and regetable remains that for ages are preserved in the rocks. But clearly no such remains could ever be found in the

1 For reasons which are a little too complex to be considered here. We can only indicate the general line of reasoning by saying that the centmal heat as it moved ontwards from the rocks nearer the surface expanded them. 


\section{THE EAR'TH THE ABODE OF LIFE}

rolcanic or molten rocks of the earliest stages of the earth's life. Think for a moment of what the simplest forms of life are. A great deal has been heard of microbes and bacteria during recent years, and we may therefore assume that every one has some knowledge of the structure of these simplest living things. They may be compared to tiny bladders of jelly-so small that the microscope is necessary in order to see them, and sometimes so much smaller than this that the best microscopes cannot distinguish them. Such forms of life are called "unicellular organisms," because they consist of a single cell, which contains the jelly-like substance called protoplasm, and a smaller body, smaller even than these tiny cells themselves, which is called the nucleus.

These are the simplest forms of life. But all the higher forms of life, and we may say, roughly speaking, any form of life that the unaided eye can see, is made up not of one cell but of many cells. A human being, for example, is made up of uncounted millions of cells; and millions of cells go to the formation of a worm, a fish, a gnat, or indeed to the formation of the simplest wellknown animal that the ordinary person could name. Similarly millions of cells go to the formation of a leaf or a twig. These higher forms of life are called "multicellular organisms," because they have many cells, and most often many different kinds of cells. For instance, in the body of a man there are different kinds of cells to form the skin, or the lining of the mouth, or the substance of the eyes, or the red or white corpuscles of the blood, or the grey matter of the 


\section{THE EARTH THE ABODE OF LIFF}

brain, or the roots of the hair-to name only a few. 'Thus we see how complicated the structure of animals has become since life first made its appearance on the earth. The cells joined themselves to form tissues; and the tissues joined themselves to form organs; and these things had to happen before anything like a complete animal of the higher type, or even a complete vegetable, made its appearance. Suppose by some great cataclysm, not so great as that which we have imagined in an earlier chapter, but still world-wide in its effects, the whole world should once again be swept by a great outbreak of lava and molten rocks, which of all the living things would leave traces of its existence? Perhaps a few of the animals with great bones, or the great trees, might leave an impress of themselves in the depths of the overwhelming rocks, just as we can stamp the impress of the skin of our finger-tips on lot sealing-wax; but it is fairly evident that all the soft-tissued animals and regetables would disappear entirely and leave not a trace behindcertainly no trace that anybody could recognise many millions of years afterwards. It is still more certain that the simplest forms of life, "the unicellular organisms," would leave no trace at all. We know that side by side with the complicated organisms that we can see the simplest organisms exist now ; and must have existed at the beginning of life. Yet when we examine the records of living things in the rocks which were formed in the youth of the world, and go back right to the earliest of these forms of life that have ever been discovered, we find that such specimens are all of the rather higher (if 


\section{THE EAR'TH THE ABODE OF LIFE}

not of the lighest forms of life). From that we infer that life must have existed niany ages before the period of such remains, though, as we should have expected, all examples of the earlier forms have disappeared.

Where did this life come from? Lord Kelvin once rashly committed himself to the notion that life might have been brought to the earth on one of those flying pieces of rock, which we have already spoken of, which are named meteorites, or on a fragment of some other planetary body that had been cast out into space. The speculation is not so wildly improbable as it has sometimes been considered to be, because recent researches have shown that it is not impossible for life to survive at the very low temperatures which a meteorite would experience on its way through space, and also that the time which a small body would occupy in travelling, let us say from Mars to the earth, would not be too great for the prolonged existence of some germ of life on the meteorite. On the other hand, there is nothing in known meteorites to suggest that they came from worlds where conditions exist suitable for life as we know it; and, moreover, even if we shut our eyes to these improbabilities, we are no nearer to a solution of the problem of where and how life began. To say that it was brought to earth on a meteorite is merely to throw back the problem another stage, for we have still to ask how life began on the meteorite and on the planet from which it came. The indirect evidence regarding the probable beginning of the era of life on the earth is also extremely difficult to examine, and we can only say that the best geological 


\section{THE EAR'TH THE ABODE OF LIFE}

authority leans to the idea that the conditions when life would have been possible on the earth were finished long before the earth had finished growing, and that these conditions may have existed when the earth was about the size of Mars. Consequently the first beginnings of life may have existed at depths hundreds of miles below the earth's surface of to-day. 'The life was then, however, only of the very simplest kind; it was probably vegetable life. Probably also the first life appeared in the ocean, though it is not altogether unlikely that it may have begun, and have gone on developing, in fresh water-in those great pits which were first formed by volcanoes and which afterwards became lakes and then seas.

For our purpose, however, it will be sufficient to say that life began in the great bodies of water which were accumulating on the globe, and which owing to the washing down by rain and rivers and stream and wave action of land materials were becoming "salter," or more highly charged with mineral salts of various kinds. The early forms of life were of the nature of jellyfish, or simple organisms which were permeated by the fluid in which they dwelt. The sea was then warmer than it is now, and there are reasons for believing that it was something above $100^{\circ} \mathrm{l}$., perhaps higherperhaps rather hotter than we should now care to bathe in. It was also at the beginning an ocean which was much less salt and had much less lime in it than now. Its water was a good deal "softer." It was, however, becoming much more hard, more like the Dead Sea, which, as everybody knows, is a body of water so 


\section{THE EARTH THE ABODE OF LIFE}

charged with mineral salts and accumulations that a bather cannot sink in it, and will emerge from his bath encrusted with salty deposits. As the early ocean became more and more saturated (with lime and carbonates, etc.), the more vigorous of the living forms in the water began to resist the change in various ways. They tried to meet it, or to alter themselves so as not to be incommoded by it.

This is a very familiar occurrence in natural life and evolution. Perhaps the commonest example of it that we can select is the formation of corns on the human feet and hands. A corn, properly considered, is the defence raised by the skin against unusual or discommoding pressure or friction. When a boot is too tight, or when a plough handle or a cricket bat or a golf club is continually clasped tightly, a "callosity" or horn-like defence is formed. In some cases a blister is antecedent to the corn; and we may regard this not only as showing the need for the hardening of the skin, but as being a stage preliminary to it. There are many other instances. Hair is formed as a protection to the body, and owing to nature's economies is not usually formed when clothing takes its place or heat renders it unnecessary. If the heat is too great, or the light beating on the unprotected skin is too strong, then another form of protection takes the place of hair. Why is it that races living near the Equator wear "the burnished livery of the burning sun," and show black or brown pigmentation of the skin? It is becruse this pigmentation arrests the penetration of 


\section{THE EAR'TH THE ABODE OF IIFE}

the rays of the sun more effectively than a garment. Lately Dr. Sambon has pointed out that the white linen clothes which Europeans generally wear in the tropics, though they look cool, are not sufficient screens against the rays of light and heat, and has suggested that white men's clothes, to be properly protective against the sun, ought to be woven of threads of two colours, so that the garments should be white outside and black inside. Apply these principles to animals in sea-water, who were distressingly affected by conditions to which they had never been subjected. What would happen? The weaker would probably be killed by the change in the conditions, just as some fresh-water fishes and animalculæ would be killed now if plunged into sea-water. The stronger would, however, become acclimatised, and would in the course of successive generations struggle to adapt their bodies to the new conditions.

'Thus the living organisms in the earth's early sea contrived to cut themselves off from being bathed with the novel carbonaceous water. They cut themselves off from it in the course of generations by closing thenselves off from it with skin or membrane. Many of them stirred up their cells to secrete lime and exude it so as to form for themselves a more or less impervious covering or shell. Finally, as they grew to like the mineral water less, they continually made fresh experiments to avoid it, and the more enterprising and adventurous got out of the ocean altogether, and migrated to the air or the land, perhaps by way of the shore sands and 


\section{THE EARTH THE ABODE OF LIFE}

muds. This period, when the ocean seems to have passed its best stage for supporting all forms of life, appears to have been that which is geologically known as the Cambrian. After this period there was a wealth of ferns, of animals able to leave hard traces of themselves in the fossil records. Before this period there was no physiological need for either skin or shell. But once the skin and shell had been developed, primarily as a defence against the sea-water, their great advantages for purposes of the struggle for life among all forms of animals soon made themselves felt, and so they were retained. 


\section{CHAP'TER XI}

\section{LIFE IN OTHER WORIDS}

F life was not brought to the earth from another planet, then life was created, or originated, on the earth. Some of the conditions which attended its birth have been considered, and they amount to this: that the temperature of the earth, the elements of the earth, the conditions of the carth's surface, oceans, and atmosphere were exactly those which favoured the origination, the continuance, and the development of living things. 'The earth, among all the heavenly bodies which we can examine at all closely, is probably the only one on which life, as we know it, would have much chance of survival.

The Sun as an abode of life we may at once put out of the question. 'Taking the planets in order of distance from the Sun: of Mercury we know very little, but astronomers like Schiaparelli and Lowell have pronounced it to be an airless, dead planet with a surface cracked in cooling untold ages ago. Venus is believed to be much like the earth, not differing greatly in size, and probably having an atmosphere of considerable extent; ${ }^{1}$ but its

1 W. W. Bryant, A History of Astrenomy (Methuen), 1907. 


\section{LIFE IN OTHER WORLDS}

appearance is so bright, viewed from the earth, that it has been surmised that what we see is not the planet itself but its atmosphere always charged with clouds or possibly snow. Of Mars as an abode of life, and of the Moon, which is the body nearest to us, we shall speak more fully in the present chapter. Coming to the outer major planets, the giant Jupiter-with a bulk more than a thousand times as great as the earth-has a constitution by no means so solid. For many reasons the belief seems justified that Jupiter must be a still hot, and almost gaseous body, without a solid crust. If Jupiter's comparatively small weight for its size and its wonderful and varying system of cloud coverings are evidence of an early stage of development and a high internal temperature, still more is this the case with Saturn. In bulk it is not far inferior to Jupiter; but it is so much lighter than water that if some of its fragments fell into one of the earth's oceans they would float there. Its outer coverings or envelopes must consist of heated gases in active circulation. Of Uranus and Neptune, still farther off, we know very little, and the progress of knowledge concerning them is very slow; but it is more probable that they are in the early stage of development attributed to Jupiter and Saturn than in the solid stage of planets like the earth. So that we may fairly dismiss the probability of the existence of life as we know it on any of them-and neglect incidentally, therefore, any possibility that life could have been carried in a meteorite from them to us. Whether there are other forms of "life" than any we know is a question hardly needing discussion. 


\section{LIFE IN OTHER WORLDS}

There remains the question of the probability of life on the Moon or on Mars; and the question of possible life on the Moon is specially worth consideration, because the earth's satellite was once part of the earth's mass. We may first repeat briefly the explanation which Sir G. H. Darwin has given of the Moon's separation from the earth. If a flexible hoop or ring is spun very rapidly it will be seen to flatten itself at top and bottom (or, as we might say, at its poles) and broaden itself out at its middle or equator. The semi-liquid earth once rotated so rapidly that its swelling equatorial belt was almost at the point of separation from the parent body. Before this occurred, however, the tension was so great that one large portion of the protuberance, where it wis weakest, broke away, and began to move around the earth at a considerable distance from it. There are several estimates of the bulk of the earth thus shot off; but we may assume that about one-fifticth of the earth escaped thus. It must have consisted of a considerable portion of the earth's solid crust, and a much larger quantity of the molten rocks of the earth's interior.

The Moon is much lighter than the earth. The earth taken as a whole weighs about five and a half times as much as water. If we consider its surface alone, this weighs rather more than two and a half times the weight of water-from which it can be seen that the interior of the earth is very much denser than the earth's surface crust. ${ }^{1}$

1 The figures are: earth's specific gravity $=5 \cdot 6$. The specific gravity of the surface material ranges from, in general, between $2 \cdot 2$ and $3 \cdot \%$, with an average of $2 \cdot \pi$. The specifie gravity of the Moon is 3.4 . 


\section{LIFE IN OTHER WORLDS}

The Moon weighs rather less than three and a half times its bulk in water. This shows clearly that the Moon is composed of material scraped off from the outer surface of the earth, rather than of matter obtained from a considerable depth. At the same time the layer of material removed had an appreciable thickness. The volume of the Moon is equivalent to a solid body whose surface is equal to the area of all the earth's oceans, and whose depth would be thirty-six miles. It seems probable, therefore, that at the time when the Moon was torn off, or shot off, from the earth, the parent body had a solid crust averaging at least thirty-six miles in thickness, while beneath this crust the temperature was so high that the materials underneath were molten or liquid, and in other places were only kept solid by the enormous pressure of the material above them. When the Moon separated from the earth three-quarters of this crust was carried away. It has sometimes been supposed that the remainder was torn into two parts, one of which formed the great land area of the Eastern Hemisphere and the other the great land area of which North and South America are the relics in the Western Hemisphere. These two great areas, at that time, floated on the semi-liquid surface like two large ice-flocs. But they were, of course, a good deal heavier than ice, and the molten stuff on which they floated was a good deal heavier than water. Later on this liquid stuff cooled and hardened. But its bottom was still a good deal lower than the surface of the great areas of land which had "floated" on it; and therefore it formed great depressions all about and 


\section{LIFE IN OTHER WORLDS}

surrounding them. Thus the depressions were there ready formed, into which the waters of the earth, beginning as rain and ending as rivers or lakes, could flow as into reservoirs. On the whole scientific men incline to believe that, according to a popular tradition, the Moon may have been torn from the earth where the Pacific Ocean now lies, and may have left that hollow behind it when it went.

Many people, scientific men and astronomers among them, have imagined the possibilities of life on the Moon. In his clever romance, The First Man on the Moon, Mr. H. G. Wells has gathered together all the more reasoned speculations on the subject. They all turn on one point-Is there an atmosphere on the Moon which would support life? There are gases of some kind on the Moon. 'There must be gases, for example, shut up in the moon's rocks; there may be gases in the Moon's interior. Mr. Wells imagined that there was a good deal of gas inside the Moon; indeed, he went so far as to suppose that the Moon was partly hollow. If it were we should perhaps be able to accept that as an explanation of the fact that the Moon is, bulk for bulk, considerably lighter than the carth, and is, in short, rather lighter than we should expect it to be. If the Moon were hollow there might be an atmosphere and water inside it, and a race of beings might live there -in the underworld of the Moon. The "Selenites," as Mr. IVells called them, would probably be not in the least like human beings, though they might be immeasurably more intelligent, because, seeing that the earth 


\section{LIFE IN O'THER WORLDS}

cooled at a later period than the moon, life might have begun earlier on the Moon, and would have had, perhaps, many hundreds of thousands of years in which to develop. Mr. Wells therefore imagined the "Selenites" to resemble in some respects a race of very large insects with enormous brains. However, we need pursue these romantic speculations no further, but must turn to inquire not whether life might exist in the interior of the Moon (which we can never see), but what would be the kind of life that could exist on the part of the Moon that we can see.

In the first place, we believe that the atmosphere there would be very, very thin; as thin as the atmosphere which is left in the bell-receiver of an ordinary air-pump when the experimenter has done the best he can to exhaust it of air altogether. ${ }^{1}$ In the second place, the atmosphere would not be one of oxygen and nitrogen as that of the earth is, but of some heavy gas like carbon-dioxide (which will not support animal life). The question is whether it would support vegetable life. Several astronomers (no less eminent a one than W. H. Pickering, of Harvard University, among them) have supposed that it might, and they have imagined great jungles of vegetation springing up on the surface of the Moon under the influence of the Sun's rays-jungles which are stricken down again when they are four days old under the oncoming of night. For the Moon's day is

1 The exhaustion produced by an ordinary air-pump is never a complete vacioum. Exhaustion which leaves only anth of the original air is unusually efficient. 


\section{LIFE IN OTHER WORLDS}

equal to sereral of ours, and when night comes there the temperature sinks to a level colder far than that of the earth's Arctic regions; so cold, in fact, that even gases would be turned to liquid and then frozen solid. It is by no means certain that the gases we have mentioned would support regetable life, but assuming that they would, we should then expect the vegetation to spring up with extraordinary rapidity-because it would be so little hampered by its own weight-when the vertical rays of the Sun were beating down on the Moon. When that was the case the temperature there would be from $500^{\circ}$ (F.) to $600^{\circ}$ (F.) higher than during the night.

Perhaps we may here explain some of the reasons why vegetation would be little hampered by its own weight on the Moon. It is similar to the reasons why light gases escape from the Moon. The mass of the Moonthat is to say, the amount of matter it contains-is so th that of the earth. 'Iherefore since the weight of a body means the measure of the force by which gravity attracts it (to the earth or to the Moon), bodies on the Moon's surface are much lighter than they are here. The ratio is almost exactly onc-sixth; consequently a man weighing $180 \mathrm{lbs}$. on the earth if transplanted to the Moon would find that he only weighed 30 lbs. there, and could carry two men at once on his back for twenty miles much more easily than he could walk that distance without a load here. He could throw a stone six times as far as on the earth, and jump six times as high. Indeed, jumping over a moderate-sized house would be 


\section{LIFE IN OTHER WORLDS}

a gymnastic feat scarcely worth mentioning on the Moon.

After consideration of all these facts; and despite the belief of some distinguished astronomers that changes are sometimes perceptible on the Moon's surface; and that hoar frost can be perceived there; and perhaps volcanic eruptions-the general conclusion arrived at by astronomical authority is that organic life does not exist either on the Moon or in it; and we may conclude this outline of the speculations concerning it by quoting the American astronomer, Professor N. S. Shaler: "It is naturally painful to conclude that the Moon is and always has been deprived of those features of existence which we deem the nobler; that it has never known the stir of air or water or the higher life of beings who inherit the profit of experience, and thereby climb the way that has led upward to man. That these large gifts have been denied to the nearest companion of the earth has its lesson for the naturalist. How vast are the effects arising from the interrelation of actions .... If the gases could have been retained in the Moon (by its attractive force) there is no reason why it should not have had the history of a miniature earth. As it is, from the beginning it appears to have been determined that the Sun should not warm it in the same way as the earth; that rain should not fall on it, nor the stirrings of life and energy be visible on it. There is no imaginable accident that can alter its state. Just as it is, our Moon is likely to see the Sun go out."

This chapter may be ended by a brief application of 


\section{LIFE IN OTHER WORLDS}

some of these considerations to the case of the planet Mars. Next to the Moon Mars is our nearest neighbour, and the erection of great telescopes in America, one of them at Flagstaff Observatory, Arizona, where the air is extraordinarily clear and telescopic vision unusually penetrating, has stimulated the observation of the planet to a very great degree during recent years. Mars has an atmosphere not nearly so dense as that of the earth, but still dense enough in all probability to support some form of organic life. It may, for example, support regretation. In some other respects Mars resembles the earth. It has arctic circles; it has clouds, though whether these are of vapour or of dust is not quite certain ; and it has a less variable temperature by far than that of the Moon. There are, at any rate, some of the conditions to support and perhaps to encourage life; and if we could be certain that the atmosphere in Mars more nearly rescmbles that of the earth, and that its temperature was such as to be sometimes above that of our Arctic regions, then it would be difficult to deny that life, and probably intelligent beings, existed there. One very able and intelligent astronomer is convinced that life and intelligent beings do exist there. This is Professor Lowell, of Flagstaff' Observatory, who has devoted a number of years and a great deal of money to the careful observation of the planet. He has brought forward many cogrent arguments to show that Mars might be inhabited, and that great telescopes can discover signs on it, and may discover further signs, which are a reason for supposing it to be so. It is not, however, within the range of this book to examine these reasons in 


\section{LIFE IN OTHER WORLDS}

detail ; and we need only say that in the first decade of the twentieth century most astronomers, despite the close examination of Mars and its markings, which had been conducted for more than a generation, were still not convinced that life as we know it could exist there. 


\section{CHAPTER XII}

\section{THE HARDENING OF ROCKS}

FTER the time when the great overflows of lava
took place, spreading over continents and someand outbursts began to diminish in violence, and the world slowly settled down to conditions something like those which we see in our own day. The seas were forming; there was rainfall and summer and winter on the earth. The rains and the winds, the summer heats and winter snows were more violent than now, and the volcanic activity of which we hare spoken was much more fierce than anything of which mankind has any recollection. In the British Isles the rainfall in a year averages something in the neighbourhood of thirty inches. In some regions of the earth it is as much as four times that amount, and deluges of fifteen inches have fallen in a day. But in the era of which we have spoken deluging rains that were to be measured in feet rather than inches fell incessantly. The air was saturated with moisture, and it no sooner descended on the warm earth than it steamed back to the clouds again. For reasons not unlike these, nor unconnected with them, the great currents of 


\section{THE HARDENING OF ROCKS}

air fed by the constant transference of vapour from the earth to the skies, and the condensation of the vapour to rain, falling again on the earth, were greatly magnified. Thus the rocks of the earth, some of them only cooling and not yet hardened, were subjected to "weathering " of a kind of which it is hard to form any sufficient idea. The key to all geology is that what is going on now on the earth is similar to what always has been happening, (differing in degree rather than in kind), and that consequently the rocks of millions of years ago were washed by rivers down to the lower levels and were deposited as sediment in streams, in lakes, and in the sea. 'Thus the age of the "sedimentary rocks" began while the earth was still too warm to preserve any restiges of life.

Earthquakes much more violent than now and volcanic outbursts often upset the steady order of things, but the earth was settling down. During this settling-down process rocks, as we have seen, were being formed by deposits; but they were very liable still to be invaded by bursts of volcanic activity from the inner cauldron of the earth, and they were very apt to be twisted out of their regular shape by great earth morements. They were also liable to be baked by the neighbourhood of the restless, unconfined molten rocks, nearer then to the surface than now. Geologists call the great period of time when all the rocks continually flowed out on to the surface of the earth, and were, in fact, all molten before they solidified, the Archæan Era (from a Greek word signifying the beginning). Next in order to these rocks are those which were laid down in the argitated times when the earth was 


\section{THE HARDENING OF ROCKS}

still warm, and when the climate of the earth might be described as a continual thunderstorm. In this period earthquakes still had a great deal to do with the formation of the rocks, but then, as now, the sea and lakes and oceans laid them down. Geologists call this the Proterozoic Era. There are great masses of these Proterozoic rocks in North America. In Arizona the three periods of rock formation are sometimes visible together, and may, indeed, be perceived in some of our photographs; the Archæan all jumbled together being the lowest; Proterozoic lying crumpled or tilted over them, and the later rocks resting more regularly on these strata. In America, however, these separate ages of the Proterozoic rocks can be identified, and each age is represented by rocks thousands of feet in thickness. Three separate ages of rocks are found in this great era in North America. It is not very important to remember their names, which are merely those of the localities where these great deposits are most marked, but it is important not to forget that each of these depositions of rocks represents a period in the earth's history older than the lifetime of a river or a lake and as old as the lifetime of a continent. The lowest of these divisions consists of rocks that are much altered by the heat of the rocks below. The topmost division is hardly altered at all. In Scotland we have similar rocks. The Torridonian sandstones, 8000 to 10,000 feet thick, are believed to belong to this era. In France also, in Spain, Germany, Finland, Sweden, India, and Brazil, the Proterozoic rocks are found. In the lowermost of them are no signs that living things ever existed, but in the upper ones 


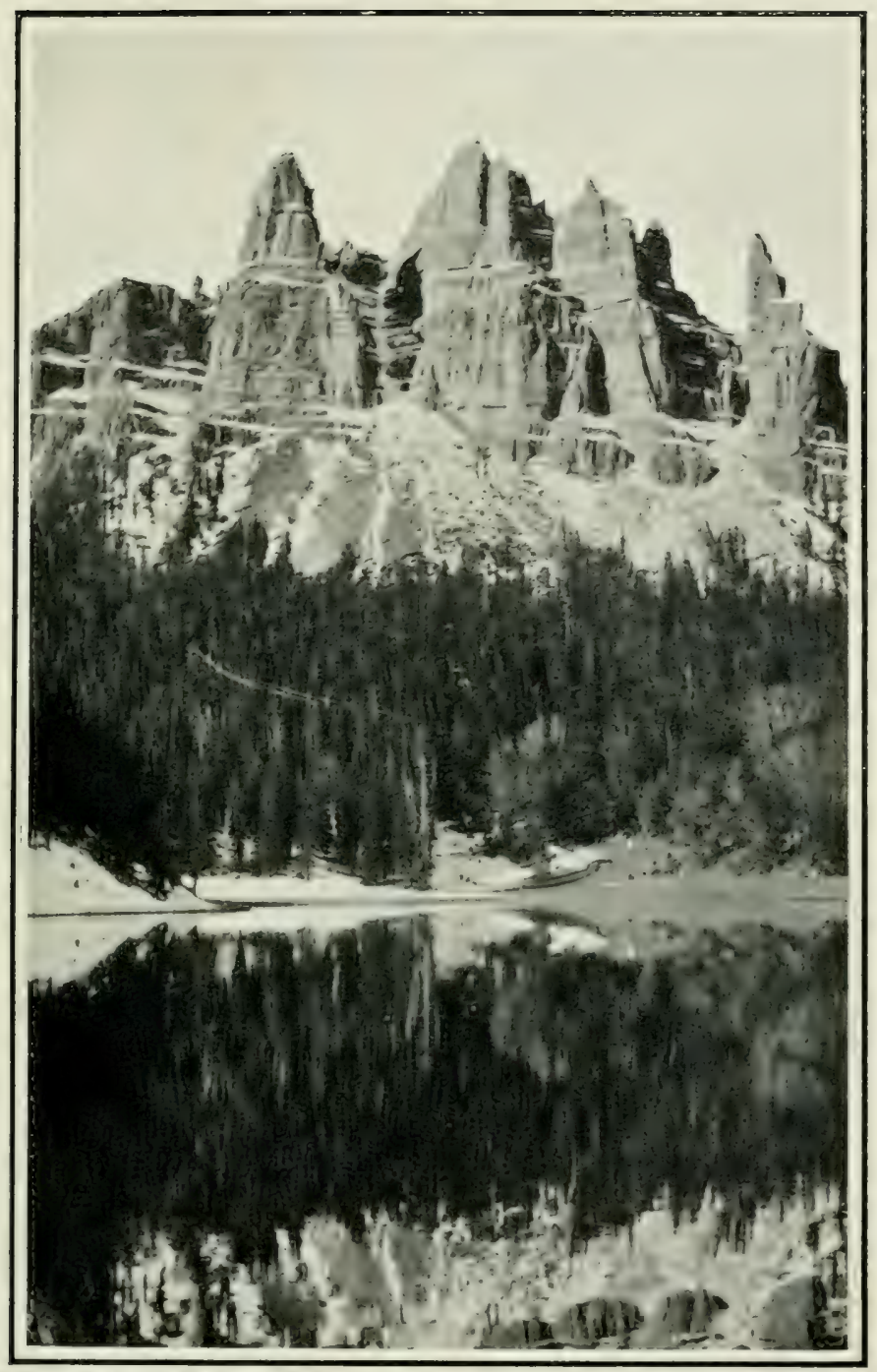

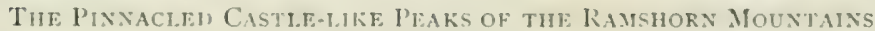
OF IVYOMING

The successive strata of sanilstone are clearly evident in the peake. 



\section{THE HARDENING OF ROCKS}

signs of life begin to appear. We may see in them to-day the first fossils. A fossil means literally a thing dug up, and was a term applied at first to all kinds of mineral substances taken out of the earth. We use the word now exclusively for the remains of plants and animals embedded in any kind of rock. In later chapters of this volume a good deal will have to be said about fossils, and of the way in which they tell us the kind of life that existed when they were first sunk in the rocks where now they are found, and how also they give us information about the climate and the distribution of land and sea, of lake and of river, in those eras far " in the backward and the dark abyss of time."

For the present, however, we may concern ourselves with the condition of the earth and its rocks in Proterozoic times, observing merely that the remains of animals which we find there are of an order (Crustacea) which shows that life had progressed a good deal from its earliest beginnings in the age when the rocks containing these crustacea were laid down. After these rocks had been deposited they were subjected to many influences of which we have only dim conceptions. In a previous chapter we have compared the layers of the undermost and harder rocks of the earth to the lines on a page of this book as they would appear if the pages were crumpled up into a ball. Sometimes the beds of solid rock have been so distorted that they look like waves of the sea; sometimes they have been completely overturned; hardly ever have they been suffered to lie down flat. More than that has happened to them. 'Their very nature has been changed. 


\section{THE HARDENING OF ROCKS}

This was done partly by heat, partly by pressure, partly by shock.

Let us consider the heat first. When a mass of erupted molten rock forces its way through the earth's crust, it produces effects which are quite easily recognised on the rocks it penetrates. Limestone becomes hard and crystalline. Rocks with silica in them become glassy and like quartz or other hard rocks which are sometimes polished to make ornaments. Clayey strata become baked into hard brick-like rocks. The changes are not altogether due to the heat. The eruption of rocks is accompanied by steam at high pressure and with all sorts of acids in the steam, so that chemical changes are also produced. It has been supposed by Sir William Crookes that diamonds, which are crystals of carbon, were produced by carbon being melted at some enormous heat under great pressure. Given the requisite conditions of heat and pressure, the parts of rocks which by their chemical composition are susceptible to crystallisation will form into enormous crystals-not unlike the intrusive rocks themselves. 'They can, however, be readily distinguished from the shapes which the intrusive rocks (like basalt) assume. The basalt rocks which form, for example, the Giant's Causeway in Ireland were volcanic lavas. Sometimes the lavas were masses which had solidified underground and had been thrust up by pressure from below or have been exposed by the weathering of the rocks above. Sometimes they have been lava poured out on the surface. The black compact kinds most often are seen in forms like columns. If these veins of rolcunic 


\section{THE HARDENING OF ROCKS}

rock have been thrust up through a bed of coal, the coal is changed or "metamorphosed "where the basalt has pierced it. Sometimes it becomes hard coal like anthracite; sometimes it is changed into graphite-the black rock of which pencils are frequently made.

Limestone pierced by basalt becomes marble. When sandstone is discovered in contact with ancient volcanic rock it is found to have lost its reddish colour, and to have become white, grey, green, or black. It separates into crystals; it becomes glassy and hard. All these instances are those of rocks which we can perceive to have been altered by coming into contact with great heat. But there is another kind of change of a very much more widespread character which can be perceived among the most ancient of those rocks which we know must have been first quietly laid down as sediments. It is sometimes spoken of as "general metamorphism."

This widespreading change may extend over great regions and vast extents of country. The most striking series of such rocks was first described by Sir W. E. Logan, Director of the Canadian Geological Survey ; and he estimated the thickness of them at 30,000 feet. They lie beneath all the unaltered rocks, and are (in North America) the rocks which were the base or foundation of the North American continent before the later sedimentary rocks were laid down on them. They are called the Laurentian rocks, because they were first found in the neighbourhood of the St. Lawrence River; but they exist in many places besides Canada and North America; and the foundations of Scandinavia and of the Hebrides are 


\section{THE HARDENING OF ROCKS}

of the same texture and material. Now this change or metamorphism does not appear to be the same as that produced by the intrusion of hot eruptive rocks. Let us take a simple instance. We have seen that limestone is changed by heat into marble. Sometimes its fossils are preserved; sometimes they completely disappear. Sometimes it is threaded by veins of harder and more crystalline rocks. But in the case of the white marble of Carrara, which was once a bed of coral, the change scems to have taken place less violently, less suddenly, more gradually. The change was due, therefore, not to violent heat suddenly applied, but to the penetrating action of water, probably aided by sustained heat, and certainly aided by pressure. When a rock is subjected to sufficient pressure its rery structure will alter; its original constituents may be torn out of it, pressed out of it, filtered out of it, and afterwards rearranged.

Once more let us call attention to the astounding effects which great pressures can hare. If pressure enough be applied iron can be made to flow like treacle; and the pressure of two or three miles of strata is enough to crumple or shear or tear any rock however hard. Now we have shown that in the earth's long history some regions are always being denuded of materials in order that these materials may be laid down as sediments elsewhere. These movements may be compared to those of a pair of scales, in which we are continually taking weight from the scale pan that is weighted in order to put it into the scale that is empty. The scale that is weighted is the land from which mate- 


\section{THE HARDENING OF ROCKS}

rial is being removed by the rains and the rivers; the scale that is empty is the sea, in which the eroded material is laid down to form beds and strata. These two scales are never quite balanced. But suppose a time comes when we have taken all the material we can from the weighted scale, so as to make the hitherto unweighted one the heavier-what will happen? The newly weighted scale will inevitably fall, and we shall have to begin to reverse our system of taking from, and adding to, the scales. Similarly there will always come a time when there will be a flow of the earth-mass from the areas which have been receiving great loads of sediments, towards the areas which have been robbed to supply them. Think for a moment how the weight of a mountain set up in a plain might act if we can imagine some giant force piling up the mountain higher and higher. The mere weight of the mountain would tend to make it settle, and begin to press outwards all round its base. If you find a difficulty in seeing how this could be, imagine the mountain to be made of pitch. In such a case we can quite easily realise how it would spread. Similarly mountains, or even great plains and plateaux, of sediment built up for millions of years in the oceans, would tend to spread; and they would spread towards the land which in the first place had supplicd them with materials. At first, of course, the stiffness or rigidity of the land would resist this spreading. But the masses thus built up would become so great and so heavy in the course of millions of years that no stiffness of the land could resist their spread. They would begin to roll or slide towards 


\section{THE HARDENING OF ROCKS}

the land; the heavier parts must always roll towards the lighter. The action would be as resistless as the slow moving onward motion of those masses of ice called glaciers; or as the morement of the great ice plains in Greenland; or of those ice plains which in Antarctic regions are always spreading towards the sea.

There are two views of it. There is the outward pressure of the regions where the sediments of rock are being laid down. There is the inward pressure towards the regions which have lost soil. Sometimes these two actions may conspire. A region where great denudation is taking place may send its waste material towards the sea, where it is deposited near the coast and not far from the highlands or mountains or plateaux which founded the soil. 'The shallows near the shore become a belt which is being loaded; the big mountains near by are a belt which is unloading; and thus there are two strains set up together. It is not hard to see the enormous crumpling effect which this would produce on the lower strata one or two miles beneath the surface of the sea and three or four miles below the topmost crests of the mountains. These are circumstances which may not be common; but the reader will find a quite sufficient explanation of some of the crumpling, and many of the changes in composition and appearance of the deep-sunk rocks, if he remembers the great pressure over them, and the fact that the high regrions may be supposed always to have a tendency to slip towards the lowlands. 


\section{CHAPTER XIII}

\section{EARTHQUAKES IN GEOLOGY}

$\mathrm{T}$ is more than likely that earthquakes in the geological past were very much more violent, widespread, and frequent than they are now; and they may have had a more potent effect in overturning the rocks of the earth. Even now their effects and the circumstances which accompany them are tremendous and terrifying. When the great earthquake comes, says Major Edward Dutton in his book on Earthquakes, it comes quickly and is quickly gone. Its duration is generally a matter of seconds rather than of minutes, though instances have been known in which it lasted from three to four minutes. Perhaps forty-five seconds would be a fair arerage. The first sensation is a confused murmuring sound of a strange and even weird character. Almost simultaneously loose objects begin to tremble and clatter. Sometimes almost in an instant, sometimes more gradually, but always quickly, the sound becomes a roar, the clattering becomes a crashing. The rapid quiver grows into a rude violent shaking of increasing amplitude. Everything beneath seems beaten with rapid blows of measureless power; loose objects 


\section{EARTHQUAKES IN GEOLOGY}

begin to fly about; those that are lightly hung break from their fastenings. The shaking increases in riolence. The floor begins to heave and rock like a boat on the waves. Plaster ceilings fall, the walls crack, the chimneys go crashing down, everything moves, heaves, tosses. Huge waves seem to rush under the foundations as if driven by a gale. The swing now becomes longer and still more powerful. The walls crack open. A sudden lurch throws out the front wall into the street, or tears off or shakes down in rubble the whole corner of the building. Then comes a longer swaying motion, not unlike a ship at sea, but more rapid; not alone from side to side, but forward and backward as well, and both motions combined with a wriggle which it seems impossible for anything to withstand. It is this compound, figure- 8 motion which is so destructive, rending asunder the strongest structures as if they were built of clay. It is the culmination of the quake. It settles into a more regular and less violent swing; then suddenly abates and ceases.

Out in the open country the signs and portents are of a different character. The first intimation is a strange sound. Some have likened it to the sighing of pine trees in the wind, or to falling rain; others to the distant roar of the surf; others to the far-off rumble of the railway train. It grows louder. The earth begins to quiver, then to shake rudely. Soon the ground begins to heave. Then it is actually seen to be traversed by visible waves-something like waves at sea, but of less height and moving much more swiftly. The sound becomes a 


\section{EARTHQUAKES IN GEOLOGY}

roar. It is difficult to stand, and at length becomes impossible to do so. People fling themselves to the ground to avoid being dashed against it. The trees are seen to sway violently, sometimes so much that they touch the ground with their branches. . . As the waves rush past the ground opens in cracks and closes again. As the cracks close the squeezed-out air blows out sand and gravel, and sometimes sand and water are spurted high in air. The roar becomes appalling. Through its din are heard loud, deep, solemn booms that seem like the voice of some higher Power speaking out of the depths of the universe. Suddenly the storm subsides, the earth comes speedily to rest, and all is over.

And yet, says Major Dutton, this description suggests but a single instance, or a few instances, of what earthquakes are like. In some the full vigour of the shock comes with explosive suddenness. People find themselves suddenly thrown to the earth, the ground swept from under their feet. Sometimes the rolling waves of earth are absent, and the movement is a rude quiver, rapidly vibrating in every direction-twisting, contorting, wrenching the ground as if in a determined effort to shake it into dust. Sometimes the most pronounced motion is up and down, as if the earth beneath were being hammered with giant strokes. Sometimes the growth, the climax, the dying out of the earthquake movement are repeated before the first shocks have ceased, or a few minutes afterwards, or even with an interval of several hours. The last-named case is, however, uncommon, though after the first shocks of a great earthquake there are minor shocks 


\section{EARTHQUAKES IN GEOLOGY}

and tremblings for days, weeks, or months afterwards. Some of these are of considerable force, though they do not inflict the devastation of the principal earthquake. The greatest earthquakes are not always those which wreak the largest amount of destruction. Evidently an earthquake, the centre of which is situated near a great city, is more appalling in its effects than one which takes place in some desert place like the steppes of Siberia. Recent earthquakes in Italy and near San Francisco were regarded as great earthquakes because they took place in thickly populated neighbourhoods. In cities, writes Professor W. H. Hobbs, to the rumbling of the earthquake is quickly added the crash of falling masonry, and to this succeeds an uncanny grey darkness as the air becomes filled with the dust from broken bricks, mortar, and plaster.... In places the ground opens and swallows the objects which lie upon it. Ponds are sucked down and disappear, and great fountains of water gush out and flood the country. During the New Madrid earthquakes of 1811 and 1812 water was shot upwards in vertical sheets and carried to the tops of the highest trees. Near Lake Baikal, during the earthquake on January 26th, 1862, the surface of the steppe, over: two hundred square miles, was suddenly dropped; fountains opened at many parts within the sunken area, and water shot up to heights of twenty feet. 'The water gushed also in great rolume from the open wells, and where these were tightly covered by wooden caps, their lids were shot up into the air like corks from champagne bottles. On the night of September 5th, 1896, during heary earth- 


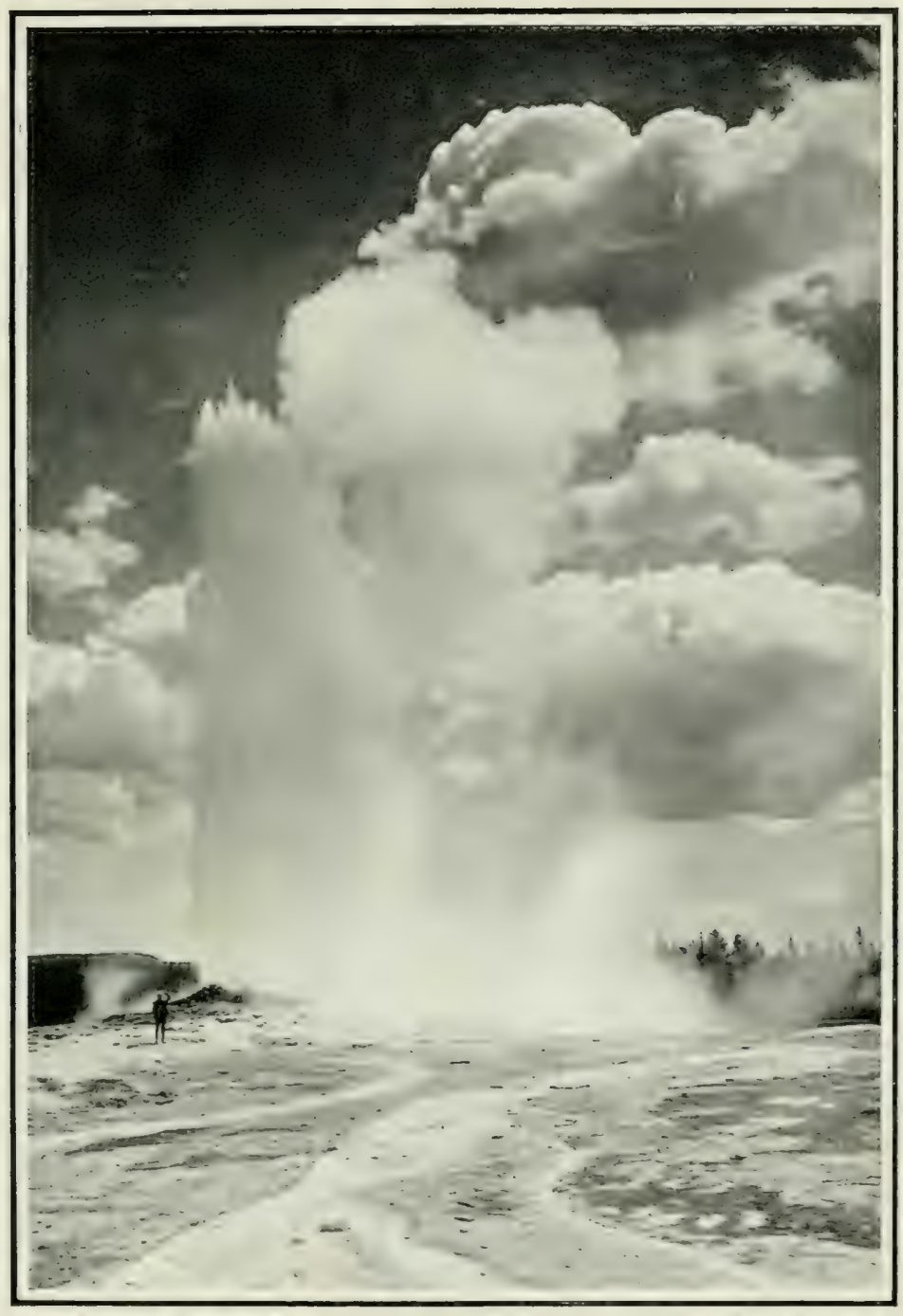

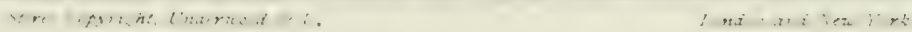

A GEYSER IN ACTION

In geysers the suggestion that the fountains of steam and hot water originate by the contact of water with hot rock is irresistible. 



\section{EARTHQUAKES IN GEOLOGY}

quake shocks in Iceland, a new warm spring suddenly opened to the accompaniment of loud roaring and whistling, and threw water, steam, and fragments of rock to a height estimated at six hundred feet. The force of the new geyser was, however, soon spent, and ten days later it ceased to flow. Nearly all the Icelandic geysers suffered changes during this earthquake, and the famous Strolitur, which had been born during the earthquake of 1789, suddenly ceased its eruption and came to an end.

In steep-walled mountain valleys earthquakes nearly always cause landslips, and these may completely block the course of a river. The lake formed in this manner during the great earthquake of January 25th, 1348, in Carinthia destroyed no fewer than seventeen villages, and to-day, nearly six centuries afterwards, the area is a great marsh. After the earthquake near Lake Baikal in Siberia, of which we have spoken and in which the ground sank, the sunken area was soon after invaded by the waters of the lake. Sometimes when the earthquake takes place near the mouth of a great river, the channels of the streams are changed. After the Californian earthquake of 1857 the current of the River Kern was turned upstream; and the San Gabriel River left its bed to follow a new course offered to it by an earthquake fissure. After the Japanese earthquake of 1891 a former lake was cut in half by one of the earthquake displacements, and one half of the lake was left high and dry. Near Flagstaff, Arizona, there is an old earthquake crack along which the waters of several rivers which intersect it all disappear down the 


\section{EARTHQUAKES IN GEOLOGY}

crevice. The most remarkable revelation of the process of lake draining during earthquake shocks was furnished, however, according to Professor Hobbs, by the former Lake Eulalie near New Madrid. After the shocks of 1812 the lake completely disappeared. On the lake bottom thus exposed there was revealed a series of fissures down the funnel-shaped openings which the waters had disappeared.

It will be seen from many of the foregoing instances that whatever are the principal causes of earthquakes, they must have played a great part in the shaping of events in the geological past; and the only limitation which we can place in the importance of the part they played will depend on whether we regard the earthquake as having been caused by a morement of the underlying strata, or whether we believe that the same cause which produces earthquakes may produce alterations in the lie of the strata themselves. In the next (hap)ter we shall describe some of the effects produced on lind by earthquakes. But impressive as some of these effects are, it is by no means certain that the greatest earthquakes take place on land at all. 'They may take place at sea, decp underneath the ocean. Our opportunities for observing such quakes, howerer, are much smaller than are afforded by land earthquakes. The instruments which have been devised for observing earth tremors will measure the smallest of such disturbances, and will record enrthquakes the centres of which are thousands of miles away. These delicate instruments often record distant earthquakes, the exact locality of which is never 


\section{EAR'THQUAKES IN GEOLOGY}

determined. No doubt, some of these distant tremors originate in the ocean bed; but the seaquake can only be localised when the water is put into a state of vibration sufficiently energetic to rock the ship and its loose objects and thus affect the senses. Vast waves are sometimes rolled in on the shores of continents, and are undoubtedly caused by some great disturbance beneath the ocean.

Such waves have been known through a long period of history in the Eastern Mediterranean, where they have ravaged the shores of Syria and Asia Minor; and it is sometimes supposed that the great deluge on which the Ark of Noah floated was accompanied by a mighty seawave, rolled in upon the lands of Chaldea from the Persian Gulf. Off the Pacific coast of South America these waves arise most often and most mightily. They have been especially formidable in the angle where the coast of Peru meets that of Chili, and the harbours of Pisco, Arica, Tacna, Iquique, and Pisagua have been repeatedly subjected to these destructive invasions. Usually they are foreshadowed by a violent earthquake, and the inhabitants, taking warning, fly to the hills. The seawave does not, however, always follow the earthquake, but it appears often enough to arouse serious fear that it may come whenever the ground is strongly shaken. The first sign of the coming disaster is the withdrawal of the sea from the shore, leaving bare the bed of the harbour. A few minutes later the sea returns in a high, irresistible wave, which overflows the adjoining lands. Again it withdraws and again returns, and these oscillations may last for many hours, slowly 


\section{EARTHQUAKES IN GEOLOGY}

diminishing in the amount of rise and fall till they die out.

The most memorable seaquake of the Chilian const was that of August 13th, 1868, when the coast of South America was shaken from Ecuador to Valdivia. In the town of Arica most of the buildings were thrown down. A few minutes later the sea began to retire slowly from the shore, so that ships anchored in seren fathoms of water were left high and dry. 'Then the sea returned like a great wall of water, which caught up the ships in the roadstead and swept them inland like chips of wood. Among them was the United States war vessel Wateree, which was carried inland nearly half a mile and was left, little injured, on dry lind when again the wave receded. The wave of this catistrophe was felt far away from Chili. It was perecived on the coasts of Australasia, Japan, Kamchatka, Alaska, and California. In the harbour of Makodate, in Japan, a series of wares was registered on the tide-gauge. The ordinary tide in that port is only about two and a half to three feet. On this occasion the water rose and fell a height of ten feet in twenty minutes. It had taken the first wave twenty-five hours to travel the distance of 7600 miles from South America. (n May 9th, 187\%, another seaquake almost as great as this was felt in many of the same places. This was on the occasion of the Iquique earthquake. At Arica the stranded hulk of the Itatere, which had remained high and dry for nine years, was picked up and swept farther inland. Like its predecesisor, the wave was felt all over the 


\section{EARTHQUAKES IN GEOLOGY}

Pacific. At Samoa the height of the waves varied from six to twelve feet; in New Zealand from three to twenty feet; in Japan from five to ten feet.

When a wave reaches shallow water it piles itself up to a height, as any one knows who has watched the waves coming in on the sea-shore, so that the height of a wave measured on the tide-gauge of a seaport is a good deal greater than that of the height of the wave when it is far out on the ocean. In fact, the mid-ocean height of the wave is likely to be inches while the inshore wave is measured in feet. An illustration of this can be seen on the coast of Cornwall, where sometimes, on quite a calm day the sea that looks so still breaks on the shore in big rollers. We cannot tell exactly how high an earthquake wave may be in mid-ocean, but we know it cannot usually be very great, though it travels at great speeds-sometimes as much as five miles a minute, or three hundred miles an hour.

Thus we should not expect that ships fur out at sea would often notice seaquakes unless the quake took place very near them. There are, however, some instances. Captain Gales, of the ship Florence Nightingale, reported that on January 25th, 1859, while near St. Paul's Rochs, not far from the Equator, "we felt a strong shock of an earthquake. It began with a rumbling sound like distant thunder and lasted about forty seconds. I was quite well acquainted with earthquakes, as I had experienced a good many on the west coast of America, but nerel had I felt so severe a one. Glass and dishes rattled so vigorously that I was surprised to find them uninjured. A good $\mathrm{k}$ 


\section{EARTHQUAKES IN GEOLOGY}

many objects fell down, and it was as if the ship were grounding on a reef." Another report from a locality not far from this speaks of a strange submarine noise not unlike distant thunder, or still more like the distant firing of heary guns. At the same time there was a vibration of the ship as though the anchor had been let go.

The foregoing are representative of the large majority of the reports of seaquakes. The ship quivers, vibrates; loose objects clatter and tumble. There is a strange thunderous noise in the sea. The first impression is as if the ship were grinding upon the bottom, and there is an instinctive rush of the crew to the deck to see if the ship is not on a reef. In some instances there are some forcible disturbances. M. Vulet d'Aourst speaks of a seaquake so severe that "the Admiral feared the complete destruction of the corvette." Heavy objects, including cannon and their carriages, were thrown upon the deck. The ship itself seemed to be hurled upwards.

One of the explanations offered of a phenomenon such as the last described is that the ressel has been near a submarine volcanic eruption of great power. The places where some or most of the seaquakes have been observed have been charted, and certain districts of the ocean have been found to produce more of these disturbances than others. Among the first to be thus determined were two, located in the Atlantic Ocean, very near the Equator and nearly midway between Cape Palmas on the southeastern coast of Liberia and Cape St. Roque, Brazil. 


\section{EARTHQUAKES IN GEOLOGY}

One of them is the St. Paul's Rocks district, of which mention has already been made. Another district from which seaquakes have been reported with exceptional frequency is the North Atlantic in the neighbourhood of the Azores. Between these islands and the coast of Portugal it may be remembered that the great quake originated which, on November 1st, 1775, destroyed Lisbon. The West Indian Deep, that profound basin of the Atlantic lying north of the Lesser Antilles and east of the Bahamas, where the Atlantic has its greatest depths and where its bottom has its greatest inequalities, is another district from which an unusual number of seaquakes have been reported. The usual explanation of their origin is that in these neighbourhoods, owing to the great pressure of water above them, there are continual slips and fractures of the sea bottom, like landslips on land, and that into the great cavities thus produced the water rushes, and thus sets up disturbances which show themselves on the surface like waves, very much in the same way that the water rushing through the escape of a bath produces small disturbances on the surface of the water in the bath. To satisfy the requirements of such a wave as rolled in upon the South American coast at Arica in 1868 would require the sudden drop of many hundred square miles of sea bottom-perhaps of several thousand square miles. 


\section{CHAP'TER XIV}

\section{SOME FAMOUS EAR'THQUAKES}

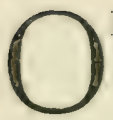

$F$ all earthquakes perhaps the best known and remembered is that of Lisbon on Norember 1st, 1755 , and volumes have been written about it. The first shocks of this earthquake came without other warning than a deep sound resembling thunder, which appeared to proceed from beneath the ground, and it was immediately followed by a quaking which threw down the entire city of Lisbon. In six minutes sixty thousand persons perished. 'The day was almost immediately turned into night, owing to the thickness of the dust from the ruined city. A few minutes afterwards fire sprang up among the ruins. The new Lisbon quay, which had been built entirely of marble, suddenly sank down into the bay with an immense crowd of people, who thronged to it for safety, and it is said that none of the bodies of the drowned were ever seen again. Following hard on the first shocks the sea retired from the land, carrying boats and other craft with it, only to return in a great wave, which completed the destruction in and about the city. 'This great sea ware, the mightiest that has ever been described in commection with an earthquake, 


\section{SOME FAMOUS EAR'THQUAKES}

is said to have washed not only the coasts of Portugal and Spain, but to have extended with destructive violence to other countries. At Kinsale, in Ireland, it was strong enough to whirl vessels about in the harbour and to pour into the market-place, and it was of great violence also at the island of Madeira. Portions of the sea-coast between Cape-da-Roca and Cape Carvociro fell away into the sea, and the damage was very great along the coast between Cape St. Vincent and the mouth of the Guadiana. The great Sierra da Estrella, on the west of the Tagus valley, was split and rent in a most remarkable manner, and threw down avalanches of rock into the valley.

The great earthquake which shook Calabria and NorthEastern Sicily in the year 1783 stands out in rather striking contrast with other disturbances of history, because it was carefully studied by a great number of skilled observers. Among them were Vivenzio, the court physician of the King of Naples, who has supplied us with a narrative of the events; Grimaldi, the Minister of War, who at the King's command visited the region and has left accurate measurements of the greater and lesser fissures associated with the earthquake; Pignaturo, a physician, who kept a record of the long-continuing shocks, together with an estimate of their intensities; the French geologist Dolomieu; and Sir William Hamilton, who was the British Ambassador at Naples. The Acarlemy of Naples sent a special commission to the scene of the earthquake's destruction, and prepared a bulky report of great scientific value. Calabria is a 


\section{SOME FAMOUS EARTHQUAKES}

country which has many times been racked with earthquakes; the disturbances being almost as conspicuous for number as in Japan. The areas shaken have not usually been great in extent, but as regards the geological changes and the loss to life by which they have been accompanied, they rank among the greatest in history.

The shocks of 1783 , which cost thirty thousand lives, came without warning on February 5th, and in two minutes threw down the structures in hundreds of cities and villages scattered through Calabria and North-Eastern Sicily. The great central granite formation of Calabria, which was but slightly disturbed by the first shock, was more heavily shaken by those which followed; and it was noted by the early writers on this earthquake that the mountains had been a little raised in comparison with the neighbouring plains at their bases. The fact of the elevation of mountains by carthquakes or some other underground disturbance has been elsewhere noted. On November 19th, 1829, a great earthquake shook the Chilian coast for a distance of twelve hundred miles north and south. 'The greatest energy was shown about one hundred miles north of Valparaiso, where the coast was found to have risen suddenly from three to five feet for a distance which has never been accurately ascertained, but which is known to have exceeded thirty-five miles. In 1835 and in 1837 similar elevations of the coast were caused by earthyuakes at Concepeion, about three hundred miles south of Valparaiso, and at Valdivia, about two hundred miles south of Concepeion. Charles Darwin, in the Voygage of the "Beagle," says: "I have courincing 


\section{SOME FAMIOUS EAR'THQUAKES}

proofs that this part of the continent of South America has been elevated near the coast at least from four to five hundred feet, and in some parts from one thousand to thirteen hundred feet, since the epoch of living shells." Darwin finds his evidence in the raised beaches near the coast on which these shells abound. That this uplift has been going on by small and sudden movements, from a foot to ten feet at each shock, for more than two centuries is attested by good evidence. The coast in many places is proven to be from twenty to thirty feet higher to-day than it was in the middle of the seventeenth century. Sir Charles Lyell, in his Principles of Geology, gives a most interesting account of the sudden upheaval of a portion of a mountain range, with the accompaniment of a great earthquake, near Wellington, in New Zealand, in January, 1855. Both the North and South Islands of that colony have been affected by upliftings during the nineteenth century, and these movements have been attended by powerful and far-reaching earthquakes. The changes wrought by these movements on the shores and farther inland as well have been remarkable during the last hundred years.

Another example of the same kind of activity is seen in the occasional rise of islands from the sea; but to this we shall refer again, and for the present we may return to the Calabrian earthquake, which presented many curious and many characteristic features. During the earthquake the surface of the country heaved in great undulations, which were productive of a feeling of sea-sickness, and which, according to some observers, made the clouds appear to 


\section{SOME FAMOUS EAR'THQUAKES}

stand still, as they will sometimes seem to do from the deck of a tossing ship. The fissures which appeared in the ground were numbered by thousands, and sometimes the displacements of the earth amounted to as much as ten feet. Houses were lifted high up; in other places the land or the sea-floor sank several feet. Many of the fissures opened, spurted out sand or water, and then closed again; and some of the Calabrian plains after the earthqualie were found to be dotted with circular hollows, on the arerage about the size of carriage wheels, which were like wells, but were sometimes filled with sand instead of water. These were afterwards found to be V-shaped. In addition to these hundreds of small coneshaped hollows or wells there were other water basins more deserving the name of ponds or lakes. One of these in the neighbourhood of Seminara, to which the name of Lago di Tolfilo was given, was about a third of a mile in length, and was so copiously fed by the springs ranged in a fissure in its bottom that all attempts to drain it proved uscless. Near Sitizam a valley was completely choked up by the landslip from opposite sides, and behind this new dam a lake was formed which was about two miles in length and one mile in breadth. Virenzio states that fifty likies arose at the time of the earthqualie, and the Government surveyors, who included ponds, counted no fewer than 215. The first eflect of the more violent shocks was generally to dry up the rivers. Immediately afterwards many of their beds were so blocked up over them that the rivers overflowed. From the rock of Seyllat opposite to Charybdis, in the Straits of Messina, large 


\section{SOME FAMOUS EAR'THQUAKES}

sections of cliff were broken off, in one instance for a whole mile's length of coast. The sea and the neighbourhood was greatly disturbed; and soon after the fall of the cliffs of Scylla the sea rose to a height of twenty feet, and the wave rolling over the coast-line drowned 1500 people.

Japan is perhaps as unstable an area as anywhere exists on the earth, and the records of its earthquakes are more complete than in any other country. The number of destructive earthquakes recorded there in the last fifteen hundred years is 223. Since the beginning of the seventeenth century the records are fairly. perfect, and it is found that since then a destructive earthquake has occurred somewhere in the Japanese islands nearly every two and a half years. For the lighter shocks systematic observation has become necessary, and the Japanese, with that development of the scientific spirit which is so remarkable an accompaniment of their progress during the last generation, have organised an Earthquake Recording Service-a Seismological Bureau-at which such conspicuous meteorologists as Mr. John Milne and Dr. Knott have worked, and which has produced great seismologists among the Japanese themselves. As many of our readers are aware, the earth is hardly ever still; it trembles continually like a boiling kettle, though not for the same reasons; and the delicate instruments for measuring earthquakes, which are called seismometers, show continual earth tremors or earth shivers. Since 1888 the earthquakes of all intensities recorded in Japan give a yearly average of 1447 shocks, or a daily average 


\section{SOME FAMIOUS EARTHQUAKES}

of four. Until the great earthquake of 1891, the greatest shocks within the memory of living men were those of 1854-5.

The earthquake of October 28th, 1891, shook an area of 243,000 square miles, or more than three-fifths of the entire area of Japan, though the greatest damage was done on the Mino-Owari Plain, a broad expanse of country occupied by rice fields and surrounded by mountains. Without the least warning the blow came, and in the first shock 20,000 buildings fell, 7000 people were killed and 17,000 were injured. Innmmerable fissures great and small appeared all over the plain, and the houses in the thickly packed villages fell like packs of cards. The plain is one of Japan's great gardens, and supported almost 1000 people to the square mile. Villages were thereabout continuous, and a narrow lane of unusual destruction could be traced through them for twenty miles. After the first shock there were numerous smaller ones, and during the next five months no fewer than 256 shocks were recorded in all. Among the more remarkable effects of the earthquake was the actual shifting of the country. Along a crack many miles in length the plain after the earthquake was some feet lower on one side than on the other. Reservoirs and swamps were formed, as well as sand pits and mud craters. The most conspicuous effect, however, from a geological standpoint was the shifting and distortion of the stratr.

A few years later, on the 26th and 2rth August, 1896, oceured the remarkable Icelindic earthyualie, which 


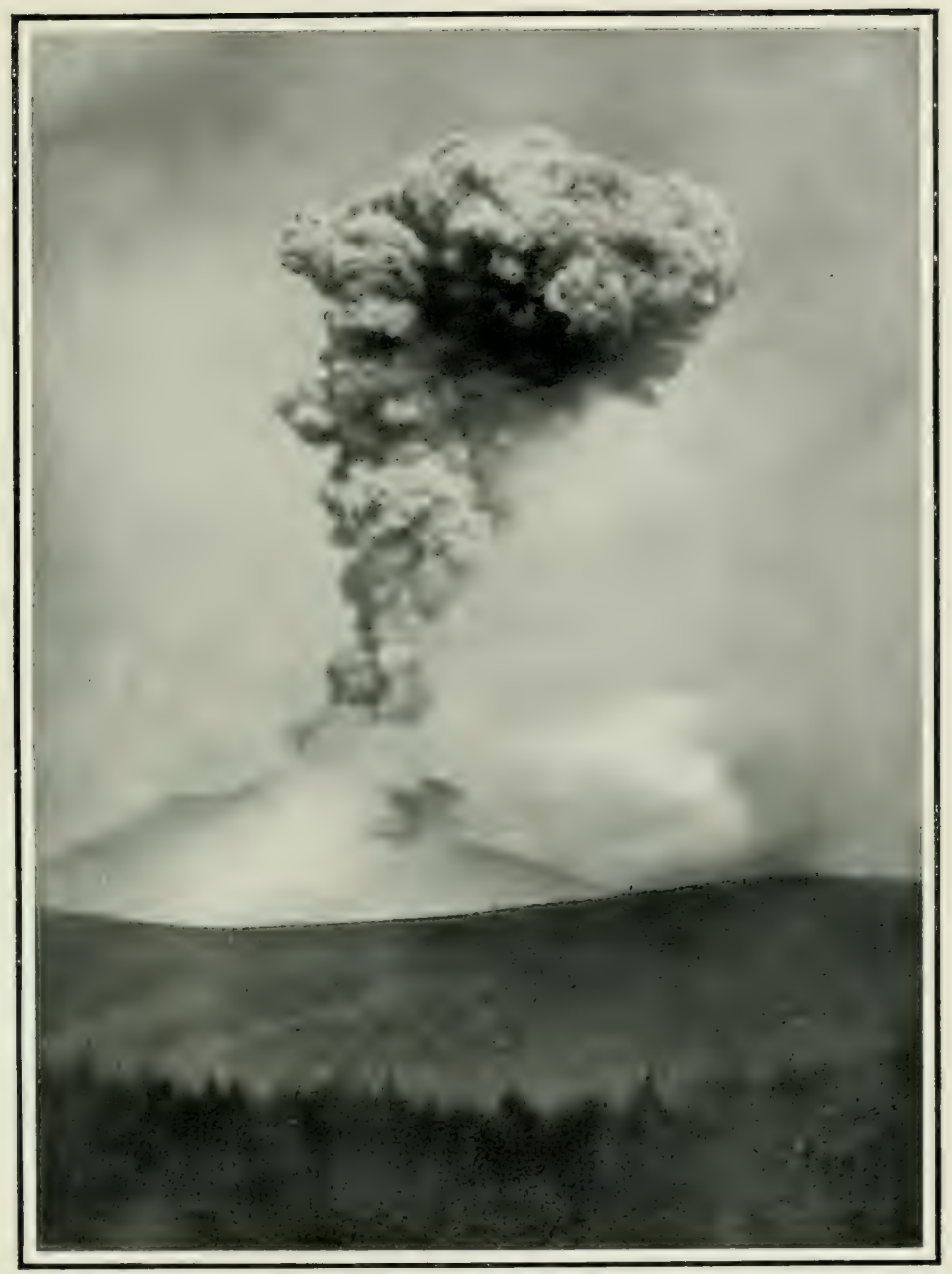

Whot, G. C. Wizer

The Curious Eruption of Mount asama, Japan

Mount Asama in nearly $E_{\text {mo }}$ feet high, and the crater is nearly a mile acruss, and has a depth of about 1000 feet. Steam is being continually discharged. The above display was photo. graphed from about 8 miles distance. The discharge was about $x+\frac{1}{2}$ miles high, and shot up to that height in some ninety seconds. The evident inference is either that water is being forced out of the rocks by voleanic ation. or that the eruptions are of the nature of steam explusions caused by water which comes in contact with molten rock. 



\section{SOME FAMOUS EARTHQUAKES}

affected a triangular plateau, bordered by high mountains, including Mount Hecla and other well-known volcanoes, in the south-western portion of the island. During the shocks the earth's surface was thrown into waves, so that neither man nor cattle could stand. Persons who were lying on the ground near a cliff were by the shock thrown bodily over the edge. A high hill in the plain is described as shaken "like a dog coming out of the water," and a thick mantle of loose soil which had covered it was afterwards found distributed in heaps about its base. The surface of the plain was scarred by open fissures or by rock walls which had been caused by the earth's rising on one side of a fissure. One of the fissures was nine miles and another seven miles in length. The mountains round the plains were riven by clefts, and many landslips occurred. As we have mentioned elsewhere, a new geyser was formed, throwing up water to an enormous height, but soon spending its early force; and many geysers and springs were violently disturbed.

An earthquake of a very different kind occurred the next year in the province of Assam, India (June 12th, 1897). Unlike the Icelandic earthquake, almost the whole damage was here the result of the first shock. Everything was destroyed within the first fifteen seconds of the earthquake, and the heavy shocks had all passed before two and a half minutes had clapsed. In this brief space of time an area of $1,750,000$ square miles had been shaken and 150,000 square miles laid in ruins. A member of the Geological Survey of India, who was in the town of Shillong, says that a rumbling sound like near thunder 


\section{SOME FAMOUS EAR'THQUAKES}

preceded the shocks by a second or so and increased in loudness, so that when masonry began to fall the noise and rattle of the falling stones were hardly to be perceived. Unable to stand on his feet, this observer sat down on the ground, and not only felt but saw the ground thrown into violent waves as if "composed of soft jelly." These waves seemed to run along the ground. When the shocks had passed all the masomy houses in Shillong had been levelled to the ground, and over each hung a cloud of pink plaster particles and dust. Some of the shocks scem to have occurred with a kind of twist, and stone monuments were given the appearance of corkscrews. There were left many fissures and depressions in the ground, and the rivers and lakes and streams were greatly affected. 'Thirty new lakes were formed; along the great Brahmaputra River rolled a great wave ten feet high. One great rent in the geologrical strata at the earth's surface was twelve miles long. Important changes of level of great blocks of country were clearly shown by the alterations in the aspect of the landscape. Ranges of hills which before hald not heen visible from certain points now came into view for the first time, while others had disappeared. 'Though the most destructive shock was that felt during the first few seconds, there were others which followed, lasting for nearly a week afterwards. 'This earthquake is of special interest, because it was the first one which wats regintered on the earthqualie instruments set "1) in Europre. Since that date these instrument: have been set up all over the world, and, as we say clsewhere, a great earthquake is 


\section{SOME FAMOUS EARTHQUAKES}

now usually recorded on the seismometers and seismographic instruments set up in observatories stationed thousands of miles away.

All of our readers will recollect the Jamaica earthquake which occurred comparatively recently. Port Kingston, in Jamaica, has had its share of earthquake disasters. In the year 1692 Port Royal, the then chief city, was destroyed, and in rebuilding it the Jamaicans moved it across the harbour, because the old town site was largely submerged beneath the sea. It was a recurrence of the settlement of the ground which in part produced the earthquake of January 14th, 1907. There were slight shocks preceding the earthquake, and subterranean rumblings. The chief damage was done before thirty-five seconds had gone by, and of course the catastrophe was greater because the shocks were felt in the neighbourhood of a city. Considered by itself the earthquake was not of the order of "great" earthquakes, but many of the effects were most curious. A statue of Queen Victoria on a pedestal was partly turned round; a series of steep terraces was formed by the side of the harbour; a small spring was converted into a stream eight feet wide; and, as we all know, rery great destruction was inflicted on life and property. Soundings which have since then been made in the harbour show that its depth has greatly increased in some parts, in one instance by not less than twenty-seven feet. The greatest depression occurred near Port Royal (the old city), where a hundred yards or more of the ground was submerged by water varying from eight to twenty-five feet in depth. 


\section{SOME FAMOUS EARTHQUAKES}

Proceeding northwards from the Antilles to North America, we come to other famous areas of earthquake disturbance. In 1811 and 1812 there were earthyuakes along the lower lands of the great Mississippi River, which were felt throughout the whole of the eastern portion of the United States and as far west as exploration had gone. At New Madrid, which appears to have been near the centre of the disturbance, "subterranean thunder" appears to have been heard frequently for many years preceding the earthquake, though it had ceased for nearly a year. About two o'clock in the morning of December 16th, 1811, there came a severe shock accompanied by a noise which was like near thunder, and a few minutes afterwards the air was filled with sulphurous vapour. People thought that the end of the world had come. Light shocks were felt till sumrise; and then one more violent than the first occurred. But this was not the end. For three months the shocks went on, and in that time no fewer than $18 \%$ shocks were recorded, eight of them great ones. 'The shock of January 23rd, though as violent as any that preceded it, was surpassed by the so-called "hard shock," which came at about four o'clock in the afternoon of February "ith. It was accompanied by a discharge of sulphurous vapour in the atmosphere, and an unusual darkness which added greatly to the terror of the people. The Mississippi seemed to recede from its banks, and its waters gathered up like mountains, leaving boats high up on the sands. "The waters then moved inwards with a front wall fifteen to twenty feet in height, tearing the boats from their moor- 


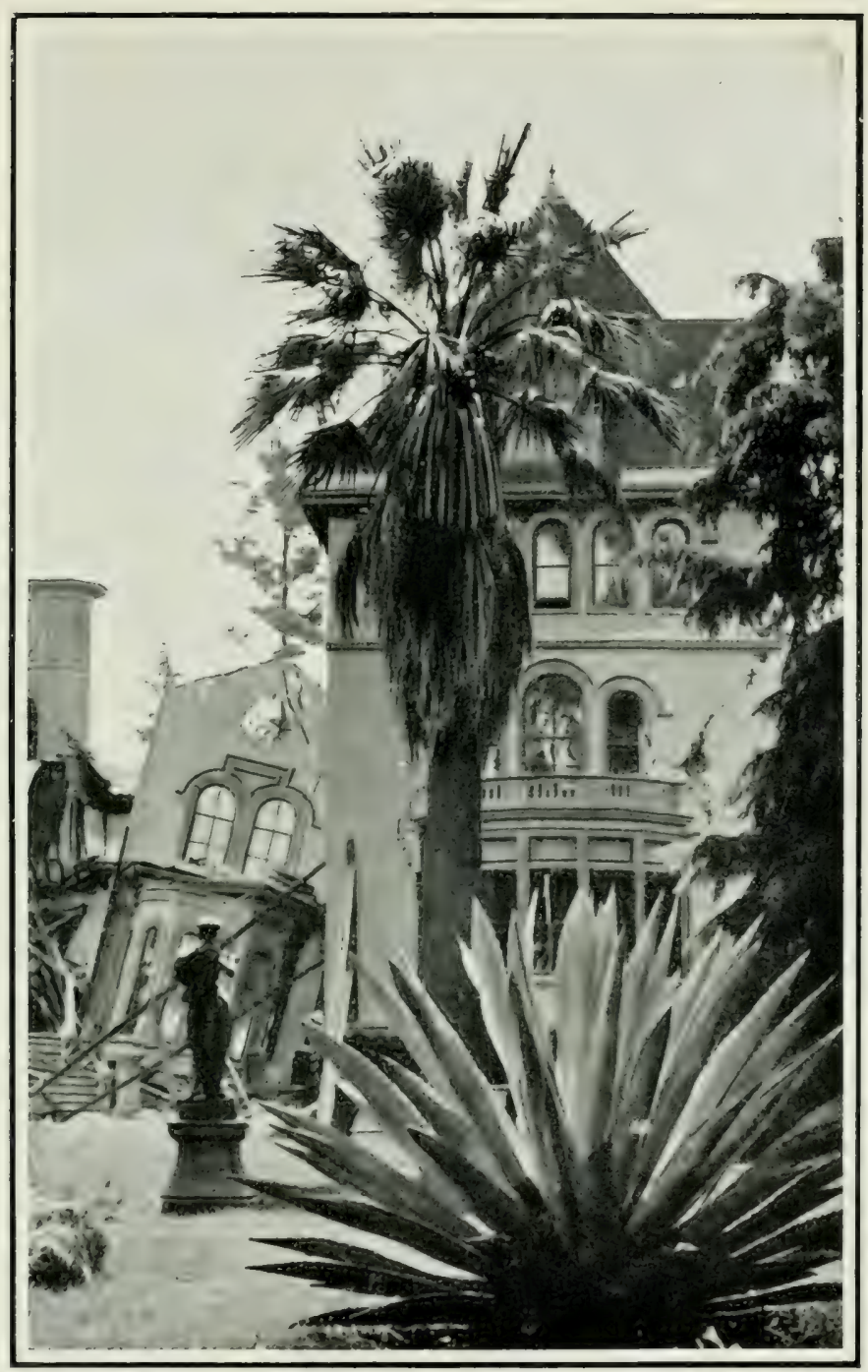

A HoUse DESTROYED BY AN EARTHOUAKE,

This was Senator Stanford's house at Palo $\mathrm{N}$ to, about 25 miles from San Francisco, which is situated on a fault or ancient fracture of the earth's surface. 



\section{SOME FAMOUS EARTHQUAKES}

ings and carrying them closely packed up a creek for a quarter of a mile. The river fell as rapidly as it had risen, and receded from its banks with such violence that it took with it a grove of cotton-woods which hedged its borders. These trees were broken off with such regularity that it was hard to persuade people who had not witnessed the catastrophe that it had not been brought about by human agency." During all the greater shocks the earth's surface was reported to have been raised in great crumplings, the crests of which opened into fissures. Some of these were six hundred to seven hundred feet long and twenty to thirty feet wide, and water and sand and even coal ${ }^{1}$ were spouted out of them to a height of forty feet. Many craters and holes in the ground were formed, surrounded by rings of sand ; and traces of them remain to this day, a century-old monument of the destruction wrought. Notable changes in the level of the country were effected; new lakes and new islands came into existence; some lakes disappeared; some of the lakes then formed remain to this day. On the eastern bank of the Mississippi a lake a hundred miles long, six miles wide, and ten to fifty feet in depth was formed; and another lake, known now as Reelfoot Lake, which came then into existence, is twenty miles long, seven miles broad-larger than Windermere, and deeper. 'The fishermen's boats to-day float over the top of eighteenth-century cypress trees. In addition to sections of country which were depressed and submerged, an area of some twenty miles in diameter was elevated into a low dune twenty to twenty-

1 Or "lignite," a form of hard pitch. 


\section{SOME FAMOUS EARTHQUAKES}

five feet above the level of the plain of the Mississippi. Many years after the great shocks, smaller ones were felt; and even now scarcely a year passes without slight tremors in this region, and small fissures are still formed in the ground.

It must be repeated that the great earthquakes are not those of which most is heard. The earthquake of San Francisco which àid such widespread damage because it took place in the neighbourhood of a thickly populated city was, after all, less in magnitude than the Sonora earthquake of 1887, which took place in a great expanse of desert country in which few people lived and few towns had been built. But this earthquake was felt all over the countries of Mexico and the State of Arizona; and a range of mountains, the Sierra Teras, was uplifted between faults which opened upon either side. Millions of cubic feet of rock were thrown down from the slopes of the mountains into the deep canons and water-courses, and cliffs of hard rock were shattered and split as though by a charge of giant powder. The Yakutat Bay carthquake in Alaska changed the whole face of the country over thousands of square miles during September, 1899; and along the shore of the bay the shore showed that in some cases it had been lifted from five to thirty and in some cases even fifty feet. New reefs and islands were formed; and a study of the country and the coast-line seems to show that from time to time this neighbourhood, like the beaches south of Valparaiso, is being lifted by some agency, perhaps the gradual elevation of a continent, perhaps by continuous earthquake action. 


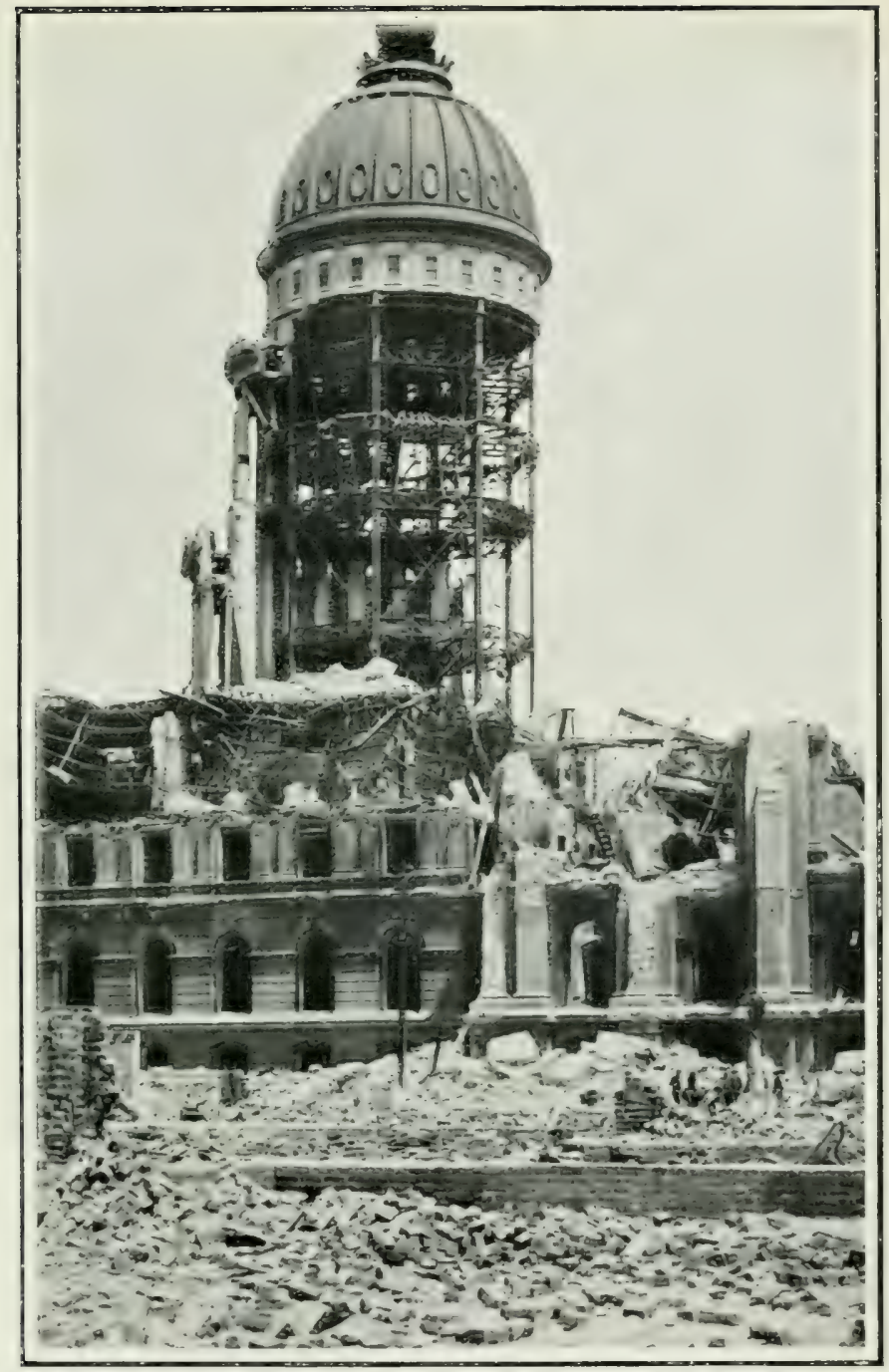

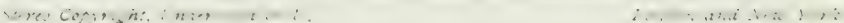

Tine RUINS OF THF MAgNificent City IIAL, of SAN Francisco

The freat earthquake of roos caused this destruction. Some of the distortive effects of an earthquake movement can be perceived. 


\section{SOME FAMOUS EARTHQUAKES}

But if the San Francisco earthquake of April 18:h, 1906, was not of itsclf a very great earthquake, it brought about an enormous amount of damage. The heavy shocks came without warning at about five o'clock in the morning of April 18th. They lasted about a minute, and then went off into lighter quakes, which were felt till evening, and for many days after, gradually growing smaller and smaller. The loss of life, though great, was but a tenth of what it would have been had the worst shocks came at a later hour when men were at their places of business and the children in school. As it was, the greatest loss was due to the fire which was started by the earthquake, and which was soon beyond control, because the water-main had been snapped by the earth movement. The cause of the earthquake has been generally assigned to the slipping of the strata of California. Athwart the whole state runs a straight furrow, like an ancient earthquake crack of primeval times, which is about four hundred miles long, and the rocks about which are still liable to slip. As we have said, however, the Californian earthquake, though accompanied by great destruction of property, and by the characteristic accompaniments of fissures in the ground, and slight elevations and depressions of the country over a line sixty miles long, was not a very profound earthquake.

Rather a curious coincidence may be here noted. We have spoken of submarine earthquakes and volcanoes and of islands which are raised by something akin to rolcanic action or earthquake action underneath the sea. 


\section{SOME FAMOUS EARTHQUAKES}

Some weeks after the Californian earthquake the officers and crew of the U.S. Fish Commission steamer Albatross, while on their way to investigate, with Professor Charles H. Gilbert, the fisheries of Japan, passed the group of islands known as the Bogoslofs, and to their astonishment perceived that a third island had been added to the other two. Professor Gilbert, in a letter concerning the first sight of the island, on May 28th, wrote: "When I saw the Bogoslofs in 1890 there were really two small islands about $1 \frac{1}{2}$ miles apart, one of them steaming and the other cooled off. This has been the condition for a number of years, so the hot one had received the name of Fire Island, the cold one, Castle Island. When they came in sight yesterday, we were astonished to find that Fire Island was no longer smoking, and that a very large third island had arisen half-way between the other two. It was made of jagged, rugged lava, and was giving off clouds of steam and smoke from any number of little craters scattered all over it. Around these craters the rocks were all crusted with yellow sulphur. The new cone, occupying much of the space between the two older ones, was somewhat higher than either, but was certiinly far from 900 feet high-300 feet would be an extreme figure. There was no evidence of a central crater. The steam and fumes were given off most abundintly from cracks and fumaroles on the slopes. About these were heary incrustations of sulphur. We saw no indications of boiling water, nor did we believe that landing would be impossible." 


\section{SOME FAMOUS EAR'THQUAKES}

All three of these Bogoslof islands, which are about 120 miles south of the Pribyloff Islands, belonging to Russia in the Behring Sea, have risen above the waters hot and steaming in the last 150 years. The oldest Bogoslof, now called Castle Island, rose from the sea in 1796 ; and Kotzebue describes the first glimpse of it, as seen by a trader, named Krinkof, who had been forced to seek refuge from a storm on a neighbouring island. The birth of the volcanic islet was accompanied by an earthquake which shook the island where the trader had taken refuge, and by an outburst of fire with thunderous explosions. The island was said to emit fire for months afterwards, and for eight years afterwards the water round it was warm and its ashes unbearably hot. The eruption of 1883, in which the second Bogoslof, called Fire Island, was born, had no witnesses; but in September of that year great volumes of steam and smoke, accompanied by showers of ashes, were thrown out from the summit and through fissures in the sides and base, the bright reflections from the heated interior being visible at night. At the time of this eruption a severe earthquake was felt in the sea off Cape Mendocino, apparently in the line of the Californian furrow or rift.

The islands were visited in 1884 by the officers of the U.S. revenue cutter Corwin, and Lieutenant J. C. Cantwell and Surgeon H. W. Yemans made the ascent of New Bogoslof. Lieutenant Cantwell thus describes his experience in the Cruise of the Corvin :-

"The sides of New Bogoslof rise with a gentle slope to the crater. The ascent at first appears easy, but a thin 


\section{SOME FAMOUS EARTHQUAKES}

laver of ashes, formed into a crunt by the action of rain and moisture, is not strong enough to sustain a man's weight. At every step my feet crushed through the outer covering and I sank at first ankle deep, and later on knee deep, into a soft, almost impalpable dust, which arose in clouds and nearly suffocated me. As the summit was reached the heat of the ashes became unbearable. . . On all sides of the cone there are openings through which steam escaped with more or less energy."

Seven years after that Drs. Merriam and Mendenhall, of the Behring Sea Seal Commission, found the newer island still smoking, steaming, and occasionally roaring like a giant steam escape. The older island had quite cooled, and had become a sheer cliff or hill of cold ashes, and was, and is, the home of countless sea birds, as well as of a small herd of sea lions. Captain Cook, in the eighteenth century, had passed by the neighbourhood of this island. 'This was eighteen years, however, before it was born, and he named a pillar of ash or rock which he found there Ship Rock. Ship Rock fell in ruins five years after the birth of Fire Island.

Since that time the new island has again sunk beneath the waves. But it will probably rise again, or another island somewhere in its neighbourhood will take its place, for a great new submarine ridge of volcanic rocks is forming in this neighbourhood and has been forming for many hundreds of years. The Pribyloff Islands are known to be volcanic from the materials of which they are composed, and sprang up above the waves in the same way. 


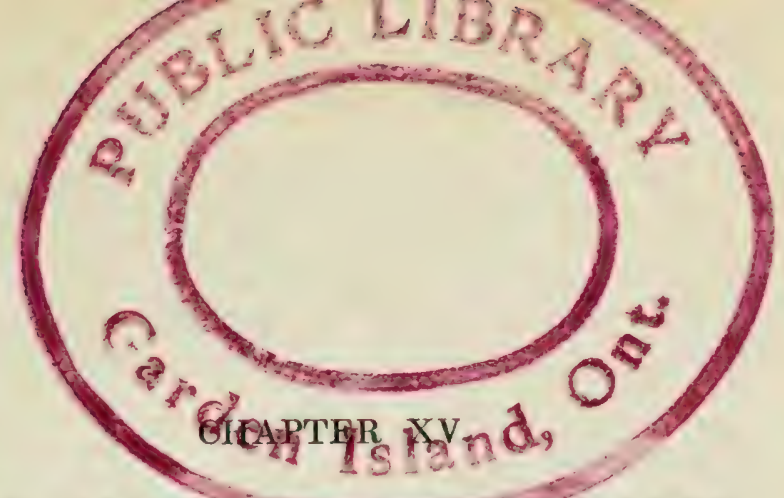

\section{THE CAUSES OF EARTHQUAKES}

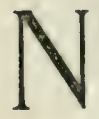

OW that we have before us some of the examples of the changes which historic earthquakes have brought about in the face of the country, it is easy to see what an important effect they must have exerted in geological history. But there are still weighty questions to be answered about earthquakes. We have seen that an earthquake can contort, upset, and twist the surface strata of the earth as easily as we can crumple a sheet of cardboard. We have yet to find whether the crumpling of the strata is always produced by earthquakes, or whether an earthquake is the culminating symptom that some agency is at work crumpling the strata. Let us try to imagine an example on a small scale. Suppose we take the top of a pill-box, and, holding it in the crook between our thumb and forefinger, compress it very tightly on all sides. What will happen? The lid of the pill-box, being subjected to stress or strain on all sides, will presently buckle and crack. We shall have produced an earthquake on a small scale, and there will be an earthquake fractureperhaps an earthquake fissure. If the whole pill-box $16 ;$ 


\section{THE CAUSES OF EARTHQUAKES}

had been used for the purpose of our experiment, and had been packed to the brim with ointment or thick liquid, and if it had been squeezed in a vice instead of in our hands, then perhaps we should have provoked still more striking symptoms of an earthquake. The ointment might have broken out through the lid. Perhaps even tiny jagged holes or craters would have been formed in the lid. Thus we see how strain may produce earthquakes. Take some nore examples. Suppose a cork is very tightly fixed in a wine bottle, and in order to get it out we employ a very powerful lever corkscrew. The neck of the bottle, under the effect of the too powerful pressure put on the inside surface of the glass, will crack or break. Similarly if we screw down a microscope too hard on a slip of glass the glass will often crack suddenly. Both these instances recently occurred within the writer's experience, and few readers can have escaped noticing one or other of them. The breakage in these instances is always caused because a strain is set up somewhere in the glass-there is more pressure at one point than another, and the glass, unable to resist this unequal pressure, gives way.

What happens when it gives way? To answer this question we had better carry our minds to the example of the pill-box lid. If the top of the box were of very brittle material, like pottery or glass, then after the breakage we know that most likely one of the broken pieces would be a little higher than the otherwould perhaps overlap it. That is what we often see 


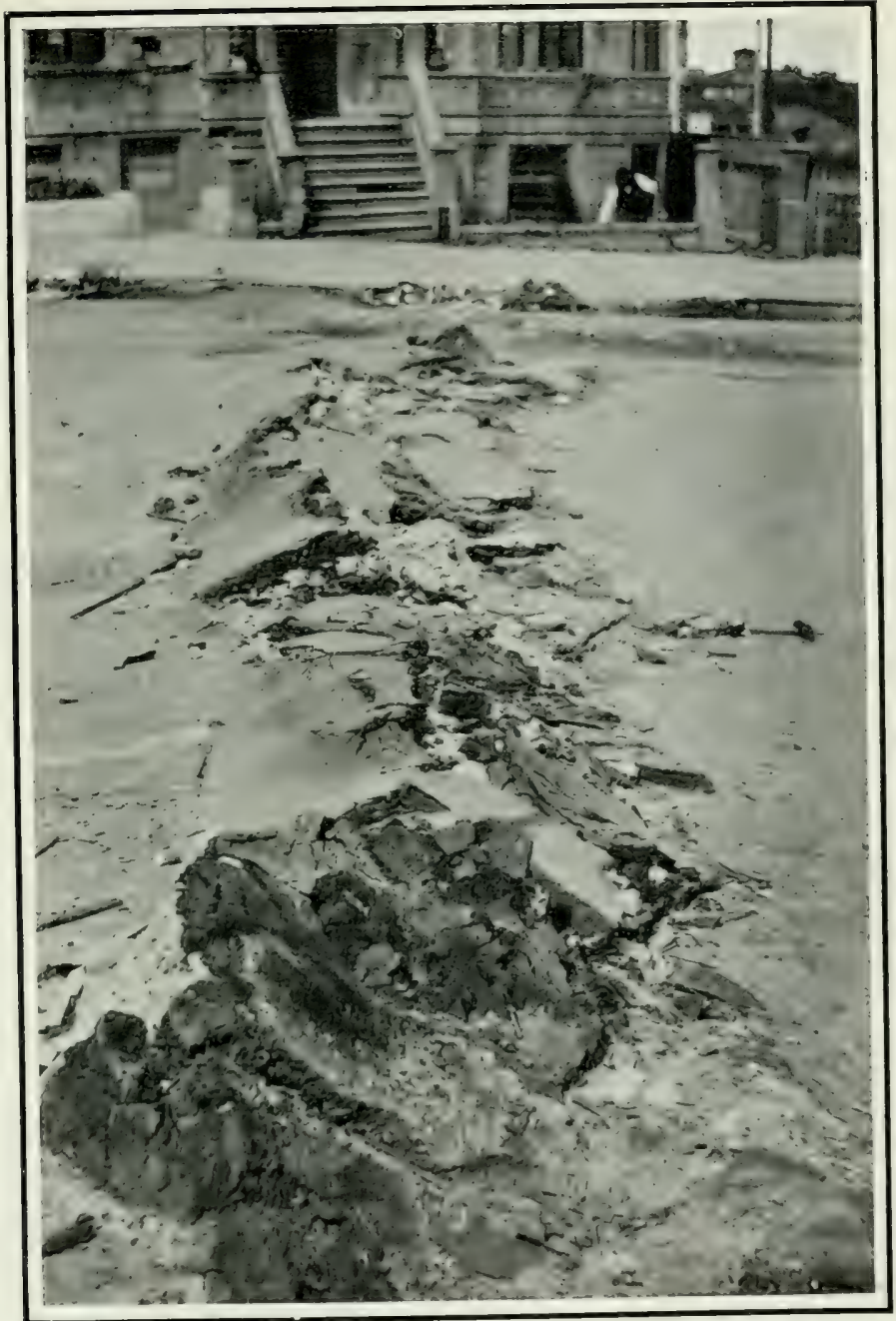

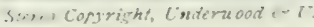

Lortou and Aiere York

THE TRACK OF AN EARTH WAVE

Showing portion of a street in San Francisco after the terrible earthquake of I $9: 6$. The resemblance of the break in the ground to the appearance of a stationary wave shuuld be noted. 



\section{THE CAUSES OF EARTHQUAKES}

when examining the geological earth strata. One stratum, instead of lying evenly with another where a crack has occurred, rests a little above it or below it. This inequality or unevenness geologists call a fault. Now we can easily see that whenever, and by whatever causes, a fault is produced, there is probably at the same time an earthquake. The fault cannot be produced without a great and shaking disturbance. Mr. John Milne, the most distinguished of British authorities on earthquakes, says that all large earthquakes originate from the formation or extension of these "faults" or great cracks in the strata.

The occurrences of these "faults" are most frequent when the process of mountain building has been going on over the earth. In other words, if we imagine a period in which some great continental area of the world's surface was slowly rising above the oceans, then at that time we should expect that there would have been great "faults" occurring in the strata, and great earthquakes following them. To quote his words: "If therefore we wish to know when earthquakes were greatest and most frequent, we must turn to those periods in geological history when mountain ranges were built, when volcanic activity was pronounced, and when great 'faults' were made. 'The first of these periods would be coincident with the creation of the Ural Mountains, the Grampians, and other mountain ranges. This took place in the earliest geologic times. Another period of mountain formation was when the Himalayas and the Alps were slowly but intermit- 


\section{THE CAUSES OF EARTHQUAKES}

tently brought into existence. In both these periods volcanic activity was pronounced, and beds of coal were formed. When the crust of the earth was crumbling, mountains grew spasmodically-(they sprang up, as it were, from out of the giant forces which we have described earlier in this book)-' faults' gave rise to earthquakes, volcanic forces found their vents, and conditions existed which gave rise to the accumulation of materials to form coal."

But, the reader will naturally inquire, if "fiults" gave rise to earthquakes, and faults are the result of pressure, what produces the pressure? And what produces the mountains? Before we answer that we must again have recourse to examples taken from common experience. A sheet of glass or of marble we usually regard as a thing that may break but does not bend. But all of us have seen glass strips, if they are long enough, bend under their own weight; and there are even marble mantelpieces which, if eximined, show that the slab of marble has bent. Thus we can readily imagine that sometimes the strata of the earth will bend by reason of the weight put upon them. If that weight is not put on them quite evenly the strata will be still more likely to bend; it will go from bending to buckling, and from buckling to breaking. As soon at it breaks there will be a "fault" formed. Those who recollect what we have said about the enormous weight of the rocks one above the other will not have to search far for the cause of weight sulficient to bend or buckle the rock stratia of the earth. And those who have followed carefully all that has been 


\section{THE CAUSES OF EAR'THQUAKES}

written about the shifting of materials from the land to the sea by the processes of denudation and erosion set up by rain and wind and carried out by streams and rivers, will easily discover where and how the shifting of great weights of the earth's surface goes on. Little by little great weights are taken from one place on the earth's surface to another, as we might shift the weights in balanced scale-pans grain by grain, till at last the heavier scale-pan goes down quickly, or it may be with a crash, and the "fault" occurs, while the earthquake follows.

There remains another question, however, to be answered, and it is, How were the mountains formed? Mountains are very closely connected with earthquakes, for nearly all the regions of the earth where the great disturbances take place are in the neighbourhood of great mountain ranges; and many, indeed most, of the students of earthquakes believe this to be the case, because the great weight of the mountains, especially when near the deep sea, induces pressure on the rocks, and consequently slipping and "faults." But the causes of mountain formation are very difficult to show with certainty. One such explanation, that of the continual shifting of portions by weight of the earth, we have already given. There is another one which may perhaps supply an additional cause. It is that just as "faults" produce earthquakes, perhaps in some cases earthquakes produce "faults." In the illustration we gave of the bottle-neck being broken by continual pressure, or the slide of a microscope suddenly bieaking witl a crash, because the increasing 


\section{THE CAUSES OF EARTHQUAKES}

pressure of a screw was greater than it could bear, we have considered cases where the pressure was slowly applied. But a tap with a hammer or any sudden shock would also produce a breakage-and "fitults," and an earthquake on a small scale-and it is possible that some of the convulsions of nature and some of their permanent effects are caused by sudden and riolent causes.

One such cause might be the violent and sudden formation of steam by the contact of water with rock at a very high temperature. Everybody knows what happens to the kitchen boiler after a severe frost. The frost clogs the pipes with ice, so that the kitchen boiler becomes dry because no water is reaching it; but it continues to grow hotter and hotter till the iron plates or iron lining become red-hot. Then the frost perhaps gives way and a small amount of witer finds its way into the red-hot boiler. The water is converted instantly into steam; and, as a result, the boiler, if it is a weak one, is blown out into the kitchen, causing grave personal inconvenience to the cook. If the boiler is a strong one, it may merely crack. Now, apply these considerations to the instance of the earth, its oceans, its thin crust, and its hot rocks situated at a depth of not more than thirty miles, and perhaps at a good deal less depth than that. What would happen if the ocean leaked through into the strata of red-hot or molten rocks? There would be enormous quantities of steam formed; and if, owing to the vast pressure of strata and water above, these quantities of steam did not instantly produce violent explosions, yet underneath there would be imprisoned, 


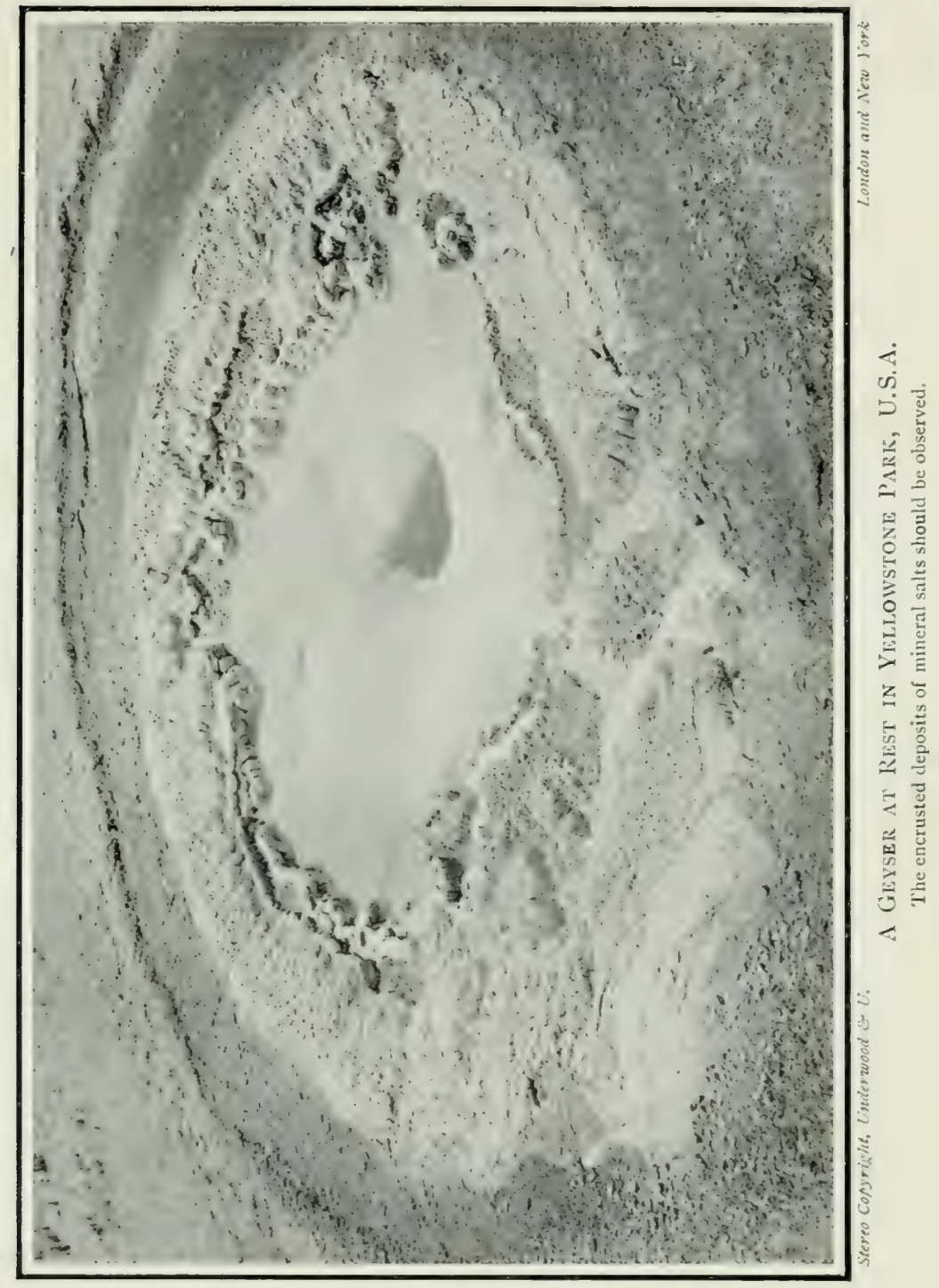





\section{THE CAUSES OF EARTHQUAKES}

so to speak, forces of tremendous power which would only await a favourable opportunity in order to manifest themselves. The hot steam until this favourable opportunity arose would be absorbed by the rocks, just as hot steel can be shown to absorb gases. We are thus face to face with the following situation, as it is expressed by Dr. T. J. J. See, the American physicist:-The internal temperature of the earth is extremely high with heated rocks quite near the surface, while the crust is fractured and leaky everywhere, and especially where the depth of the sea is greatest. The sea covers three-fourths of the earth's surface, and earthquakes are found to be most violent where the sea is deepest, and volcanoes most numerous on the adjacent shores. Can we then suppose that both earthquakes and volcanoes depend on the explosive power of steam which has developed in the heated rocks of the earth's crust? We have said that earthquakes and volcanoes are most common in regions where high mountains are near deep oceans-as on the westward of South and Central America, the Aleutian Islands, the Kurile Islands, Japan, Sumatra, Java, and other islands of the East Indies bordering on the deep waters of the Indian Ocean, New Zealand, and the Lesser Antilles in the West Indies, Iceland, Italy, and Greece. These are also the regions where, owing to the existence of high mountains, the weight, the pressure, the tear and stress on the underlying strata are greatest, and where consequently there is the greater chance of strata slipping or bending or giving way. Mr. John Milne divides the world into eleven such great "world-earthquake" districts; and he 


\section{THE CAUSES OF EARTHQUAKES}

has endeavoured to show that all the great convulsions of the earth have their origin in one or other of these areas-where usually a great mountain range slopes steeply down to the sea. There are eleven such worldearthquake districts. 'There is the Alaskan region, where on the shore Mount Elias rises to a height of 18,000 feet and where the water is 7000 feet deep sixty miles from the shore-altogether a drop of 25,000 feet from the top of the mountain to the bed of the ocean in 200 miles. This drop, without going into measurements, may be taken as typical of the rest, which are classified as the Cordillerean region, the Antillean region(in the earthquake district of which Mount Pelée at Mirrtinique and the Soufrière in St. Vincent are situated); the Andean district; the Japan district; the Javan district; the Mauritius district; the Antarctic district; three submarine districts of sunken ridges in the North-Eastern Atlantic, the North-Western Atlantic, and the Northem Atlantic; and one great land district, distant from the sea, which lumps together all the mountains of the Alps, the Balkans, the Caucasus, and the Himalnyas. In thirteen years, from the time in which earthquake investigation has become a science, 750 great earthquakes originated in these districts. On the average, about sixty great earthquakes occur every year, or a little more than one a week. In addition to these world-shaking effects there are about 30,000 small earthquakes every year, England's annual contribution to this number being about half a dozen.

What is the meaning of a "great earthyuake," and 


\section{THE CAUSES OF EARTHQUAKES}

how do we define "small" earthquakes? A small earthquake is one such as we have described as taking place in the valley of the Mississippi, and which, even though it may produce considerable disturbance in its neighbourhood, is not perceptible at any great distance away. A great earthquake is one which sends its vibrations thousands of miles. A very large earthquake, originating in any part of the world, may be recorded in any other part of the globe. Although only a few people in Great Britain have been privileged to feel a home-made earth tremor, every one of us is very many times a year moved by earthquakes. We do not perceive them because the back-and-forth motion of the ground is performed too slowly, while if there is a movement of the ground the undulations are so very flat that they cannot be perceived. But at several places in England and at earthquake observatories (seismological stations) all over the world, from Japan to Australia and from South Africa to Greenland, instruments are set up which are sensitive enough to record these tremors, though not always to locate them. Sometimes when Professor Behar in Germany, or Mr. Milne from his observatory in the Isle of Wight, telegraphs to the newspapers that signs of a great earthquake have appeared on their instruments, the world hears no more of these disturbances. They have occurred we are certain, but the place where the great cataclysm which has thus shaken the whole round world took place has been fortunately remote from inhabited portions of the earth, and has very likely been beneath the waters of some ocean. 


\section{THE CAUSES OF EAR'THQUAKES}

Earthquake waves start out from the great area where the cataclysm took place, and begin to disturb the earth in all directions, just as if we were to put a row of marbles on a table and were to strike the end marble of the row. The marble farthest from it would presently receive the shock as it travelled along the row of marbles. Any one of our readers who has ever seen a train of luggage wagons being shunted is familiar with the way in which the shock of a sudden pull or push on the part of the engine travels all down the line of wagons, and we may think of the shock of an earthquake as travelling along and through the earth in the same way. Observation, however, shows that these wares are propagated farthest in one particular direction. For example, the chief morement following the San Francisco earthquake, which originated from fault lines running parallel to the coast of California, was much more marked in countries lying to the east or west of California than in countries lying towards the south. England and Japan obtained large records of the disturbance, while in Argentina the records were extremely small. In the case of the Jamaica earthquake, where the lines of origin ran east and west, the phenomenon was reversed. Toronto received a lirrge quantity of motion, and England a very little. Another peculiarity of this phase of earthquake motion is that it may be propagated in one direction round the world to a greater distance than in an opposite direction. The suggestion is that the initial impulse was delivered in the direction towards which motion was propagated farthest. That which happens corresponds to what 


\section{THE CAUSES OF EARTHQUAKES}

we see if we dip the blade of a spade in water and suddenly push the blade in some particular direction. The water waves thus created travel farthest in the direction of the impulse.

Another curious phenomenon connected with the large waves of certain earthquakes is that they may be very marked for one thousand miles round their origin, and may be perceived on the exactly opposite side of the earth (though, of course, much reduced in size), but cannot be recorded on the earthquake instruments of the regions in between. For example, an earthquake originating near New Zealand may be recorded in that country, but not in India, Egypt, West Asia, or east of Europe, though in Britain it may make itself evident on the seismometer's record. The phenomenon may be compared to a water wave rumning down an expanding estuary. At the mouth of such an estuary it may have become so flat that it is no longer recognisable. Should it, however, run up a second estuary, we can imagine concentration taking place, so that near the top of the second estuary it would eventually become recordable on instruments. In these antipodean survivors we see the final efforts of a dying earthquake. It is only occasionally that the precursors and the followers of these large waves have sufficient energy to reach their antipodes. They die en route.

From the earliest times philosophers have held that the causes of earthquakes were associated with the contact between fire and water. Plato, Aristotle, Strabo, and Pliny all held that water and air penetrate into the earth 


\section{THE CAUSES OF EARTHQUAKES}

through hollows, fissures, and crevicen, thus reveloping in the heated interior great vapour, a part of which is expelled from volcanoes. Aristotle correctly associated seismic sea wares with earthquakes, and even Homer assigned these great disturbances of the sea to Poseidon's trident, which was also the means employed for raising up islands from the sea bottom. The withdrawal of the water from the shore after an earthquake and its return as a great wave were familiar to Aristotle, and are implied in his description of the sinking of Helike in 373 в.с.

Before leaving the subject of earthquakes we may quote some passarges from Mr. John Milne on the influence which these great disasters have exercised on the emotions. Immediately after the Kingston earthquake we read of the dazed and almost insane condition of the people. Many were affected with an outburst of religious ecistasy, thinking the last day had come. The negro population camped on the racecourse and spent their time in singing hymns. Somewhat similar scenes took place in Chili; men and women ran hither and thither, mad with terror and deroid of reason. Amid shrieks and sobs and the wailing of a multitude an "Ora pro nobis" or a "Pater noster" might now and then be heard. In carly civilisations underground thunderings have so far excited the imagination that subterranean monster's or personages have been conjured into existence, and these in many instances have played a part in primitive religions. It the time of an earthquake in Japan the children are told that the shaking is due to the movement of a fish which is buried beneath their country, and in Japan we find refor- 


\section{THE CAUSES OF EARTHQUAKES}

ences to this fish in the pictorial art, pottery and carving, literature, and everyday conversation, all of which would be unintelligible if we did not know the story of the earthquake fish. In other countries the subterranean creature will be a pig, a tortoise, an elephant, or some other animal.

The most interesting myths, however, relate to underground personages. The forty-five Grecian Titans, who were of gigantic stature and of proportionate strength, were confined in the bowels of the earth. According to the poets, the flames of Etna proceeded from the breath of Enceladus, and when he turned his weary body the whole island of Sicily was shaken to its foundations. Neptune was not only a god of the oceans, rivers, and fountains, but with a blow of his trident he could create earthquakes at pleasure. The worship of Neptune was established in almost every part of the Grecian world. The Livians, in particular, venerated him, and looked upon him as the first and greatest of the gods. The Palici were born in the bowels of the earth, and were worshipped with great ceremonies by the Sicilians. In a superstitious age the altars of the Palici were stained with the blood of human sacrifices. In Roman mythology two very familiar deities are Pluto and Vulcan. These and a host of other deities, the outcome of imagination, excited by displays of seismic and volcanic activity, we meet with every day in picture galleries, in museums, in literature, and in our daily papers. Earthquakes have led to the abolition of oppressive taxation, the abolition of masquerades, the closing of theatres, and even to the alteration in fashions. A New England paper, of 172\%, tells us that 


\section{THE CAUSES OF EARTHQUAKES}

"a considerable town in this province has been so far awakened by the awful providence in the earthquake that the women have generally laid aside their hooped petticoats."

In the next chapter we shall consider more particularly the terrible effects of earthquakes on geological history. 


\section{CHAPTER XVI}

\section{VOLCANOES AND MOUNTAIN FORMATION}

T

HE great prominence which we have given in the preceding pages to earthquakes is owing to the growing belief in the influence of earthquakes on the appearance and structure of those portions of the world's crust which are known to us. There are two views which we can take of earthquakes. One is to regard the larger number of them as being caused by slipping movements of the earth's crust. Looking at things in this way we should say that whenever there was a sudden break in the earth's strata, such as might occur (in accordance with an illustration given in a previous chapter) if all the level strata were broken up like a crumpled page of type-then that an earthquake would result. So that whenever we saw what geologists call a "fault" in strata we should know that an earthquake had occurred there. And why did it occur? IVell, if we had a massive column of steel or of granite five miles high, the steel or granite at the bottom of the column would have to sustain such an enormous weight of material above it that it would begin to 


\section{VOLCANOES AND}

spread. If we had a pyramid of the same materials five miles high, the tendency to spread would not be so great, but still it would be there. Consequently, wherever there are high mountains there is a tendency of the earth strata beneath them to spread, perhaps slowly, but inevitably; and if there is any weakness in the structure of the rocks near the base of the mountain, then these will give way with a crash. A great "fault" will be produced, and with it an earthquake.

People living on the earth will only see the results of the earthquake on the ground just immediately below their feet; and there these results are often very destructive to life and property; yet if they were all that happened, we should expect them to be corered up in time, and the "geological record" of an earthquake would not be a very important or even discernible thing a million years after it had happened. But are these things, which the eye of man can perceive, the only things that are happening during an earthquake? Is nothing happening underneath the earth which will leave its mark thousands of years after man has left the spot where the earthquake took place? May it not be that the earthquake is the outcome of some mighty force deep down in the earth; and my not this force cause both the earthquake and the greologrical "fault" which remains as the witness of its occurrence? If this be the case then the earthquake may be of enormous importance in geology.

We regard an earthquake, as we see it, as a destructive force. That is because it destroys the works of 


\section{MOUNTAIN FORMATION}

man. But earthquakes are doing constructive work as well; or, at any rate, they are usually present when constructive work is being done. Destructive forces, such as erosion, are wearing down the structure of the globe, while earthquakes are the only known forces that are building it up. It is true that when an earthquake occurs rocks often fall, loose sediment is shaken down, and other settlements occur, but the real constructive work consists in upheavals, little by little, as it may be, of beaches, islands, coasts, plateaux, and perhaps larger areas. These elevations are actually witnessed in certain earthquakes.

Many islands in the sea have been raised from time to time within even living memory.

The south-western part of the island of Crete has been elevated within the historical period.

The region about Pozzuoli and the Bay of Naples has suffered both elevation and depression. There is the famous instance cited by Sir Charles Lyell nearly eighty years ago of the Temple of Jupiter Serapis. This temple had many columns; and they are now situated on dry land. The pillars are forty-two feet in height, and for twelve feet upwards they are of smooth undisfigured marble. Then for another twelve feet they are pitted with the holes made by a marine shell-fish called Lithodomu, the stone-dweller. What are we to judge from this? The temple was first built on dry land. Then the land sank taking the temple with it, and the columns were submerged in sea sediment to a depth of some thirty feet above their pedestals. The lower por- 


\section{VOLCANOES AND}

tions of these pedestals were preserved intact, but the marine shell-fish found a home in the upper part of the marble columns, and pierced them with the chamnels and grooves. After this had gone on for a number of years the elevation of the land lifted the temple and its columns clean out of the sea again, and the marine shell-fish could no longer live in the columns. But the traces of their habitation remain.

The elevation of this coast was actually witnessed at the time of the eruption of Monte Nuovo in 1538. Moreover, the raising of the land was perceived on a larger scale round the whole of the Bay of Naples during the eruption of Vesurius in April, 1706. Professor Lorenzo found the elevation of the land at Pozzuoli to be six inches, and at Portici one foot.* The foundations of both Etna and Vesurius were ages ago laid in the sea.

In almost every part of the world there are raised beaches, such as we have already mentioned in the neighbourhood of Valparaiso, on the Chilian coast. The idea has been put forward by Dr. 'I. J. See that the same cause which produces earthquakes produces these elevations of the land and produces also volcanoes. There are many circumstances which farour this idea. Let us consider what is happening at the bed of the sea. Some years agro, when certain officers of the United States Navy were making ocean surreys, it was found that if hollow balls of thick glitss were sunk to great depths in the ocean, they came up more and more completely filled with water in proportion as the depth increased,

* The coast about Pozzuoli is now sinking again. 


\section{MOUNTAIN FORMATION}

though no breakage or cracking of the glass had occurred, and no holes in it could be discovered even by the best microscopes. In other words, it became evident that the water had been slowly but bodily forced through the thick walls of the glass (under a pressure of less than $15,000 \mathrm{lb}$. to the square inch) in less than an hour's time. Evidently, then, even such a substance as glass will be penetrated by water if the pressure is great enough.

To make a practical application of these principles, what shall we now say with respect to the ocean bottoms? In deep places the pressure of the sea-water on them is very great, sufficient to force water through glass. Obviously most of these bottoms will leak, and leak at a rapid rate under the enormous pressure operating in the greatest depths of the sea. The bed of the ocean will not leak with equal rapidity in all places; but almost universal leakage will certainly develop, and the water will be driven back into the earth at various rates. Where the rock is volcanic and badly fractured, or sandy, the leakage will be most rapid; and where the bed is made of clay or unbroken granite the leakage will be much more gradual. It will also depend on the depth of the sea, and will be greatest where the ocean is deepest, and quite insignificant in shallow water. A rapid rate of leakage would mean that large quantities of water quickly come in contact with the heated rock, and develop correspondingly great steam pressure in the crust which underlies that part of the ocean. One case in which we may suppese a rapid leakage to be taking place is in the 


\section{VOLCANOES AND}

case of rolcanoes near the sea. In the case of lava pouring from a volcano, it is observed that the molten rock enits vast quantities of vapour, of which, according to Sir Archibald Geikie, 999 parts in 1000 are steam. The enormous volume of these has been brought home to uy in recent years by the behaviour of the rolcano Mount Pelcee, from which for several years after the great eruption which devastated Port au Prince the vapours rose in clouds that were to be measured in cubic miles. Similar observations about the quantities of vapour ejected by volcanoes have been made in Japan.

While speaking of Mount Pelée we may recall another phenomenon connected with it, which also appears to bear out the supposition that in the volcano's activity the action of steam tukes a very large share. After its first outburst Mount Pelée continued to pour out lava and great quantities of vapour, as if like some gignntic cauldron it were being fed with fresh supplies of water; and there in the early March of the following year a most amazing thing took place, under the very eyes of a celebrated inventigator of rolcanoes, now dead, Professor Angelo IIeilprin, who was remaining on the island. A great olelisk of andesite (a stone not unlike basalt) was forced up from the crater. It rose rapidly, as much as five feet a day; and it reached altogether a height of 840 feet above the crater's lip. It was calculated to be about 300 feet in diameter at its base. It continued to push itself up for some months, sometimes sinking a little, sometimes rising like a colossal piston above a steam boiler. Its greatest height was 1100 feet above the 


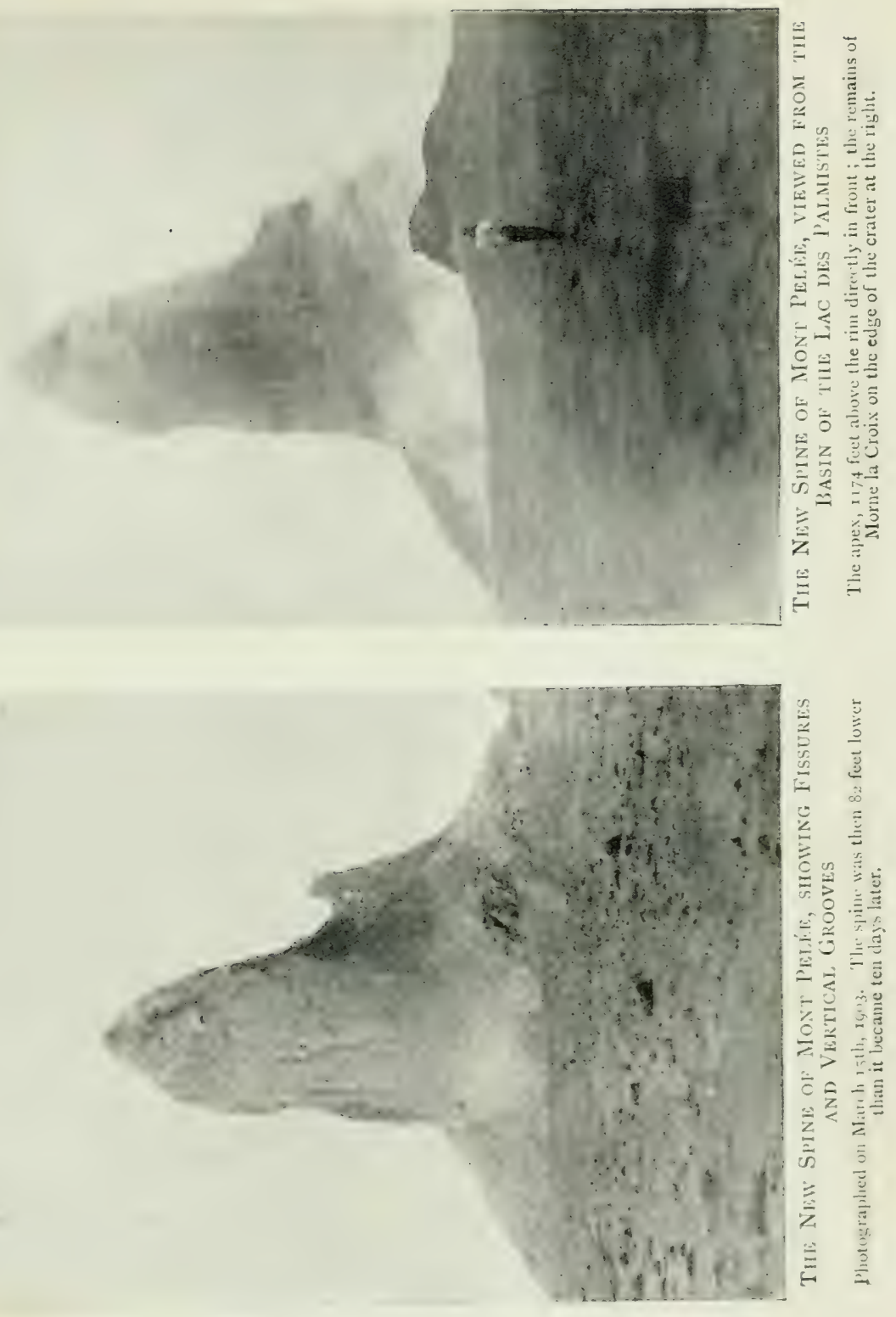





\section{MOUNTAIN FORMATION}

height of Mount Pelée, and therefore at a height of 5143 feet above the sea-level. A violent eruption would reduce its mass and its steeple-like pinnacle; but after its losses it generally pushed up again. Professor Heilprin at last got near enough to observe it, and the obelisk was found to be not of pumice stone, as had at first been suspected, but of the hard rock we have mentioned. It had, in fact, been comparable to a Titanic cork of rock which had closed up some vent far down in the crust of the earth, and which had at last been lifted by the steam pressure beneath it. It finally sank back into the crater, but it was replaced by a dome of rock which underwent similar changes in height, though on a smaller scale, to those of the obelisk. The dome of rock was, however, on a more massive scale even than the obelisk, and at one period of its career a spine, 100 feet in height, like a smaller obelisk, was pushed up through its middle. This dome was examined by the explorers, the Abbé $\mathbf{Y}$ von and M. Beaufroy, who found that the dome was a great mass of andesite, while about it were fragments of the rock of which the obelisk had been composed. They wrote at the time:-

"It is an error to suppose that there exists in the bottom of Mount Pelée a hole from which lava and gases have come out. At present there is a tremendous cork of andesite, which is called the 'Dome,' and which must have as its dimensions a diameter half a mile across at its base and a height of about 1200 feet. On all sides of the dome there are fumaroles (small cone-like craters), some of which throw out a reddish smoke, others of which 


\section{VOLCANOES AND}

discharge white smoke, and others are still surrounded with a carpet of sulphur several yards in depth."

After the great eruption of Mount Pelce in 1902 it was found by measurement that a considerable portion of the adjacent sea bottom had sunk down many fathoms. It is impossible to believe that this sinking had been caused by the mere shaking of the earthquakes accompanying that eruption. We must, therefore, suppose that after the dreadful explosions which destroyed St. Pierre and devastated Martinique a subsidence near the roots of the mountain (which is just by the sea) took place. What we should judge to have happened is that by some means an explosion took place below the sea bottom; that parts of the molten rock, moved by the forces of the explosion, were moved towards the mountain (Mount Pelíe), which thereupon broke into eruption, acting as an outlet for the imprisoned rocks. When these molten rocks were thus removed a great cavity was formed in the bed of the sea, which accordingly caved in.

A similar explanation would account for the raising of the Chilian coast-line after the great earthquakes of 1835 , of which we have already spoken. The coast and, indeed, the whole country back to the Andes was slightly raised. This could only be explained by the pushing in or forcing in of a corresponding bulk of lava under the land; and this lava could come from nowhere except from under the bed of the great trough in the adjacent sea. After an explosion (which is caused by the sea penetrating through to the molten rocks) the trough, where the "accident" first took place, would naturally decpen. 


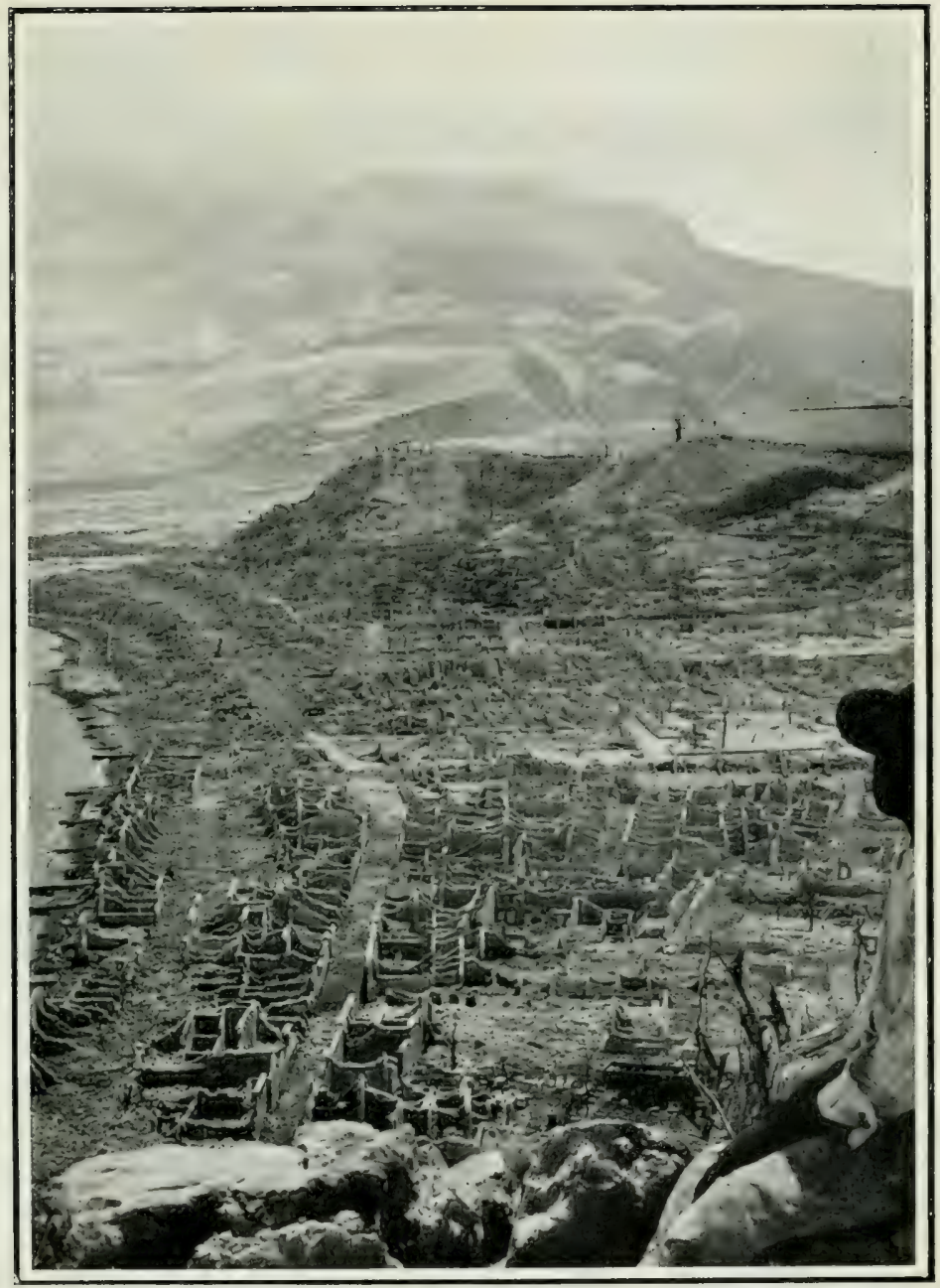

Siereo Copyricht, Lncierzeod है $U$.

London ant lew Fork

The Dead City of St. Pierre, Martinique

The town of St. Pierre was perhaps the most beautiful in the West Indies. The volcano of Mont Pelée, whrch is seen in the background, and which is five miles away, suddenly belched out deadly gases, dust, steam, and boiling mud, which overwhelmed the town and completely destroyed it. The houses were reduced to ruins, and the people were killed by the wave of hot gases sweeping down from the volcano. 



\section{MOUNTAIN FORMATION}

Moreover, if we suppose that after a time the water again penetrates, and again comes into contact with rocks that have again become heated up, there will be another explosion, and yet others. Each of these explosions will push along the ejected streams of lava, step by step, till they reach the land, and even till they reach the mountains bordering the sea. The forces thus arising would cause upheavals, even if they did not cause earthquakes. Such forces might bend strata, contort the rocks, and cause "faults."

But why, the reader may ask, do you suppose that all these explosions of lava are directed to the land? We do not suppose that they are. The lava may be forced away from the land. Then if that occurs a ridge may be upheaved, or possibly a submarine volcano.

"At the Hawaii Islands on 25th February, 1877," writes Sir Archibald Geikie, " masses of pumice during a submarine volcanic explosion were ejected to the surface, one of which struck the bottom of the boat with considerable violence and then floated. At the same time, when we reflect to what a considerable extent the bottom of the great ocean basin is dotted over with volcanic cones, rising often solitary from profound depths, we can understand how large a proportion of the actual eruptions may take place under the sea. The foundations of these volcanic islands doubtless consist of submarine lavas and fragmentary materials, which in each case continue to accumulate to a height of two or three miles, till the pile reaches the surface of the water and appears above it. 'The immense abundance and wide diffusion of volcanic 


\section{VOLCANOES AND}

ash, pumice, etc., over the bottom of the Pacific and Atlantic oceans, even at distances remote from land, as has been made known by the voyage of the Challinger, may indicate the prevalence and persistence of submarine volcanic action."

It is fairly clear, therefore, that the sea bottom is leaky, and that volcanoes which are a consequence of it are scattered freely over the deep ocean Hoor. In some places, of course, very few eruptions occur, either because the underlying rocks are less leaky or the sea is too shallow for pressure.

We have pictured the water of the oceans thus sinking down into the hot rocks. It will not always cause an explosion at once. The steam may not immediately become free, but will become absorbed in the hot rocks till the lava grows so fully saturated by the hot vapour that it swells and requires more space. When the tension becomes great enough the crust begins to shake and the paroxysm continues till the steam-saturated lava moves along the nearest break or "fault" or vent. When the underlying molten rock has thus obtained more space the agitation ceases till the tension again becomes too powerful for the crust to withstand, when another readjustment takes place. I familiar illustration of this process is seen in the lid of a tea-kettle when the stean pressure accumulates till it sets the lid quivering. As the steam escapes at the sides the agitation slowly dies down and the lid then remains quiet till the accumulating pressure again reguires relief, when the shaking is renewed. 'Thus the process is periodic, and 


\section{MOUNTAIN FORMATION}

the period depends on the rapidity with which the steam is developed. In the case of earthquakes, as already remarked, the steam is not free, but absorbed in the molten rock, and when the agitation begins this gives a similar quivering motion to the block of the earth's crust overlying it, and ceases only when readjustment occursusually by the neighbouring "fault" slipping in some way so as to give more space to the swelling lava beneath. Of course, many of the cracks caused by this swelling are never seen; and the molten lava seldom reaches the surface except when through volcano vents or cracks in mountains that are near the sea-shore; but such outbreaks are probably more common in the deep sea.

To see how effective the pressure arising from the depths of the ocean may be in driving water into the crust of the earth, we may observe that the tendency to penetrate is everywhere proportional to the depth of the sea. Now everybody knows that if a cistern be placed at the top of a house and connected with a fountain in the garden the fountain ought to throw a jet as high as the cistern because water, as the saying goes, always rises to its own level. As a matter of practice the water does not rise so high because of the resistance of the air. But for theoretical purposes we may consider the proportion true, and we might similarly say that the pressure in a sea one mile deep would thus throw a stream a mile high; in a sea two miles deep, two miles high; and so on. Now some of the ocean depths exceed five miles, the greatest, near Guam, being 5269 fathoms, almost exactly six miles. Is it therefore any wonder that the deeps east of 


\section{VOLCANOES AND}

Japan, near the Aleutian Island, west of South America, near Guam, between Samoa and New Zealand, give rise to enormous leakage of the scal bottom, and consequently many world-shaking earthquakes? A comparatively feeble pressure of water, such as hydraulic engineers use in mining, rapidly cuts away hills and washes out all their gold; in the same way the waters of Niagara, falling through only 160 feet, slowly wear away the solid rock over which they pour. What, then, may be expected of a constant water pressure which will throw a jet five miles high? Such is the pressure all over the bed of the Tuscarora Deep, and it continues from year to year, century to century. It is this pressure which forces the water so rapidly into the earth, and gives rise to all the great earthquakes and sea-wares with which Japan is afflicted. No stone on earth, however thick its layers, could withstand such a pressure; nay, under it the water would go through the hardest metals, and sink down deeper and deeper into the bowcls of the earth. Thus subterranean steam would arise beneath the crust and accumulate till relief was afforded by a shaking of the earth.

Thus we see how immensely important the same causes that give rise to earthquakes may be in moulding the outlines and contours of the rocks and the "everlasting hills." In the present state of geological knowledge we cannot say that these steam explosions are the sole causes of mountain building, but it is evident that they must play a great part in them. The action of the submarine explosions may be compared to a man digging 


\section{MOUNTAIN FORMATION}

out a trench. As he digs along the trench, the earth that he excavates he throws on to either side of the trench, so that a ridge appears on each side of the excavation. The result is the same in the case of the continuous lava explosions in deep seas, especially in those deep seas like the waters off the west coast of South America, where a great range of mountains runs parallel to an ocean that is of great depth only a short distance from the land. A trough or trench is cut downwards by successive explosions and expulsions of lava. As the trough is arched downwards like a broad letter the steam pressure from beneath cannot easily force it upwards. What will therefore happen? Imagine what would happen in a steam saucepan or kettle if the vapour could not get out at the top or lid. It would tend to blow out at the sides. Or if you think of a slab of dough rising under the effect of yeast. Suppose the baker presses a flat board on the top of the rising dough, and presses down on it so that it cannot force its way upwards. It will then naturally spread out to the sides. Similarly the rising yeasty lava under the curved ocean bed has to force its way sideways under the crust. It forces its way partly towards the land-where the mountains run along the coast as in the case of the Andes-or farther out underneath the ocean. Generally the movement of the lava will be towards the mountains till the trough gets broad and deep and the mountains very far away, and so high that their weight offers unexpectedly great resistance to the underground stream of lava. Then the release 


\section{VOLCANOES AND}

will at length become easier towards the ocean by the forcing up of ridges or volcanoes along the other margin of the trough. Ridges with peaks in them will usually result, and this is the begimning of a new range of mountains in the sea, which are destined to rise slowly from it parallel to the great range of mountains on the shore. There may thus be two parallel ridges, perhaps hundreds of miles apart, with a ralley between them. This valley may be drained in the course of ages, or filled in by the processes of erosion which we have described in the earliest chapters of this volume.

It will be of interest to quote at this point what Pliny nearly two thousand years ago said in his Natural History (Book II) on islands which have been uplifted from the Mediterranean, evidently as the result of volcanic causes:-

"Land is sometimes formed in a different manner, rising suddenly out of the sea, as if nature was compensating the earth for its losses, restoring in one place what she had swallowed up in another. Delos and Rhodes, islands which have now been long famous, are recorded to have risen up in this way. More lately there have been some smaller islands formed: Anapha, which is beyond Melos; Nea, between Lemnos and the Hellespont; Halone, between Lebedos and Teos; Thera and Therasia, among the Cyclades, in the fourth year of the 135th Olympiad. And among the same islands, 130 years afterwards, Hiera, also called Automate, made its appearance; also Thia, at the distance of two stadia from the former, 110 years afterwards, in our own times, 


\section{MOUNTAIN FORMATION}

when M. Junius Silanus and L. Balbus were consuls, on the 8 th of the Ides of July.

"Opposite to us, and near to Italy, among the Eolian Isles, an island emerged from the sea; and likewise one near Crete, 2500 paces in extent, and with warm springs in it; another made its appearance in the third year of the 163rd Olympiad, in the Tuscan Gulf, burning with a violent explosion. There is a tradition, too, that a great number of fishes were floating about the spot, and that those who employed them for food immediately expired. It is said that the Pithecusan Isles rose up in the same way in the Bay of Campania, and that shortly afterwards the mountain Epopos, from which flame had suddenly burst forth, was reduced to the level of the neighbouring plain. In the same island it is said that a town was sunk in the sea; that, in consequence of another shock, a lake burst out, and that, by a third, Prochytas was formed into an island, the neighbouring mountains being rolled away from it."

There are, no doubt, other causes which warp and bend strata. We have compared the earth to the core of a tightly wound golf ball-always in a state of strain. The strain at great depths below the surface might amount to several tons to the square inch, and it can easily be understood that breaks might occur in consequence, especially if some slight additional shock set the rocks into vibration. In the deep copper mines of the northern peninsula of Michigan the behaviour of the whole earth, with respect to earthquakes and stresses due to othcr causes, is well illustrated on a small scale. 


\section{VOLCANOES AND}

At certain times during each day blasts are set off in the solid rock at various places in each mine. Each battery of blasts is a miniature earthquake. In that particular spot, the earthquake centre, the rock is fractured within a space limited by a radius of a few feet. Within a large space, limited by a radius of a few hundred feet, elastic vibrations are set up in the solid rock which are sufficiently violent to be perceptible to the touch and to the hearing. Within this larger space no fracture of the rock occurs. Feebler vibrations doubtless extend out for miles from the point of fracture, just as vibrations extend over the whole earth from an earthquake centre. Now it also happens that in the lower levels of these deep mines, at a mile below the surface of the earth, the solid rock is slowly yielding, in a nonelastic manner, under the influence of the great weight above it, so that the larger openings are gradually closing up. This is so clearly recognised and progresses so rapidly that it is proposed as routine practice, at the deep levels in these mines, to take out the ore at the distant end of each drift first. The miners will then work back slowly toward the shaft from which the drift is entered, while the spaces in which they have recently laboured gradually close up behind them. The gradual collapse known to be in progress occurs apparently by imperceptible flow and by minor fracturing, but not, as a rule, by catastrophes which close up any opening suddenly. In this respect it is an epitome of what is taking place every year in the failing earth as it yields under such stresses. 


\section{MOUNTAIN FORMATION}

'There may be local tremors due to causes which are less immense and world-wide. One such cause might be the collapse of cavities in the earth. We are well acquainted with some such caves near the surface of the earth. These caves, especially in limestone, are commonly caused by the action of springs. Even pure water will dissolve a minute quantity of the substance of many rocks, and rain water is far from being chemically pure water. It takes oxygen and carbonic acid out of the air as it falls, and it abstracts acids out of the soil through which it sinks. 'The presence of this acid gives the water a greatly increased power of attacking carbonate of lime. Now limestone is a rock almost entirely composed of carbonate of lime. It occurs in most parts of the world, covering sometimes tracts of hundreds or thousands of square miles, and often rising into groups of hills and ranges of mountains. The abundance of this rock offers ample opportunity for the display of the dissolving action of subterranean water. The water trickles down the vertical fissures along the planes below the limestone beds. As it flows on it dissolves and removes the stone till in the course of centuries these passages are gradually enlarged into clefts, tunnels, and caverns. The ground becomes honeycombed with dark subterranean chambers, and running streams fall into these chambers and continue their course underground.

In England there are famous "pot-hole" caverns in Yorkshire and the west of England. The Peak Cavern in Derbyshire is believed to be 1200 feet long, and in some places 120 feet high. The caverns of Adelsberg near 


\section{MOUNTAIN FORMATION}

Trieste have been explored to a distance of several miles. 'The River Poik has broken into one part of the labyrinth of chambers through which it rushes before emerging again to the light. "Narrow tunnels," says Sir Archibald Geikie, "expand into spacious halls, beyond which egress is again afforded by low passages into other lofty recesses. The most stupendous chamber measures 669 feet in length, 630 feet in breadth, and 111 feet in height. From the roof hang white stalactites which uniting with the floor form pillars showing endless varieties of form and size." Still more gigantic is the system of subterranean passages in the Mammoth Cave of Kentucky, the accessible parts of which are believed to have a combined length of about 150 miles. The caverns of Luray, in Virginia, are searcely less wonderful; and in their case American ingenuity has hit on the idea of sucking the pure, dustless air out of these caverns in order to ventilate a sanatorium. Indeed, a book might easily be written on the wonders of the limestone caverns of the world, but our only purpose in mentioning them in this chapter is to indicate how the rocks of the earth may be made unstable, so that a slight shock may precipitate a catastrophe in them-a kind of subterranean landslip which in its turn may give rise to some of the symptoms of earth tremors. 


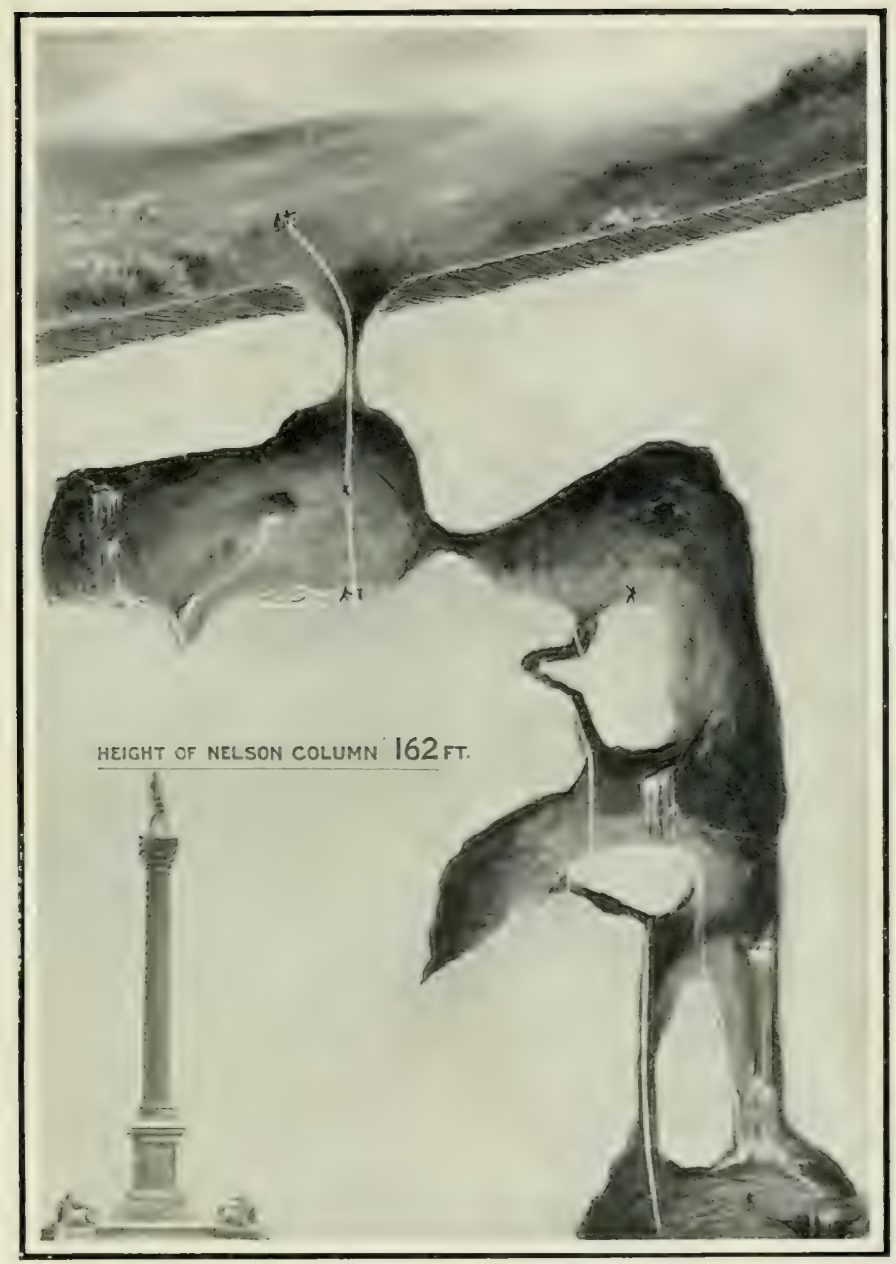

A YorkshiRe POT-HOLE: SHOWING THE EFFECTS WHICH CAN BE PRODUCED IN LMMESTONE BY UNDERGROUX゙D WATER

The immense depth may be better realised by comparing the pot-hole with the Nelson Monument, which is 162 feet in height. 



\section{CHAPTER XVII}

\section{FAMILIES OF ROCKS AND THEIR DESCENDAN'TS}

7 HUS far, in accordance with the principles of the great geologists from Sir Charles Lyell onwards, we have tried to disclose the history of the earth's crust by observing the processes which are going on to-day under our eyes. That is not, however, the only way in which history has to be written. The documents on which history rests are often lamentably incomplete. The records have great gaps in them, and very often the gaps have to be filled by that exercise of the imagination which Bishop Creighton once described as the rearrangement of facts. We shall later in this book show how naturalists can reconstruct the skeleton and even the general appearance of an animal which for ages has not been seen alive on the earth, from a consideration of fragments of the bony structure. Similarly the archrologists who inquire into the history of forgotten peoples can picture to us their lives and habits and manners from a consideration of the fragmentary weapons and pottery and architecture which they left in their buried cities: and similarly the geologist, knowing, or partly knowing, 


\section{FAMILIES OF ROCKS}

how the forces of nature are at work to-day, can attempt to describe the conditions under which rocks were laid down before man ever trod them.

In speaking or writing of the earliest stages of the world's history we have to adopt what seems to be the most likely history, modestly qualifying what we say by adding that these speculations are only the fruits of an inquiry that man has pushed beyond the ascertained facts. But we are on firmer footing when we come to deal with that portion of the globe which we can examine. The crust of the earth has been found to consist of successive layers of rock which, though far from constant in their occurrence, and though often broken and crumpled by subsequent disturbances, have been recognised over a large portion of the globe. They are the earth's own chronicle of its history. Had these rocks of the Geological Record remained in their original positions we should have known little of them, because only the most recent would have been visible. Owing, however, to the way in which the earth's crust has been twisted and cracked and broken, portions of the bottom layers have been pushed up to the surface, and the lower rocks have been inclined so that we can examine their upturned edges. Instead, therefore, of being restricted to examining a few hundred feet of earth crust we can examine many thousand feet. The total thickness of the rocks of Europe which contain fossil remains has been estimated at 75,000 feet, or fourteen miles. This vast depth of rock has been laid open to our observation by disturbances, twists, contortions, upsettings of the crust. 


\section{AND THEIR DESCENDANTS}

We shall not press on the reader in a volume of this kind any detailed classification of the strata, but he will like to know the names of the five great periods into which geologic time is divided.

The first period was the Archran, embracing the periods of the earliest rocks wherein few or no traces of life occur.

The second period was the Palæozoic (ancient life) or Primary, which includes the long succession of ages during which the earliest types of life existed.

The third period was the Mesozoic (middle life), comprising a series of ages when more advanced types of life flourished.

The fourth period was the Cainozoic (recent life) or Tertiary period, when such types of life as we know and see now appeared. This period, however, does not include man.

The fifth period is the Quaternary or Post-Tertiary and Recent, and includes the time since man appeared on the earth.

These divisions were not of the same length. The Palæozoic ages were probably far, far longer than those of any other division, while the Quaternary period is shorter than any of those which preceded it. Each of these main divisions is divided further into systems or shorter periods (just as the dynasties of ancient Egypt could be subdivided into reigns). Though the broad outlines of the sequence of the living things which existed in those periods has been the same all over the world, many local differences may be traced in the nature and grouping of the sedimentary materials in which the remains of the living things of these epochs have been preserved. 


\section{FAMILIES OF ROCKS}

'To find the oldest rocks, we must seek those which lie at the bottom or underneath all the others. Judged by this test, the oldest rocks in Great Britain are certain hard rocks (like gneiss, or the material of which volcanic veins are composed) which crop out in the north-west of Scotland, and which form the outer Hebrides. They are also known in Anglesea, and in the extreme west of Wales, at St. David's. Similar strata form the Malvern Hills of Worcestershire, the Longmynd Hills, Caer Caradoc and the Wrekin Hills of Shropshire, and the hilly district of Charnwood Forest in Leicestershire. For a long time the Cambrian rocks of Wales, so called from North Wales's ancient name of Cambria, were believed to be the oldest on the face of the earth. Up to the year 1830 even these rocks had no name or recognition, for geologists believed that it was impossible to classify them. But in 1831 Professor Adam Sedgwick, of Cambridge, began the diligent study of the rocks in North Wales, and after five years' work he was able to announce in 1836 that he had determined the general order of succession in that district of a certain ancient group of slaty, gritty, and flaggy strata. However, eighteen year's later, in 1854, Sir William Logan, who was then engaged in mapping the rocks of Canada, found along the River St. Lawrence an enormous thickness (30,000 feet or more) of gneiss, quartzite, schist, ${ }^{1}$ limestone, etc., these rocks underlyingand being, therefore, older than-the Cambrian strata,

3 Hard rocks are sometimes composed of different minerals, which are arranged in a way that reminds us of a bed of fallen leaves, and are called "foliated," from the Latin word folium, a leaf. Gneiss is a 


\section{AND THEIR DESCENDANTS}

which are also well developed in that country. To these "bottom" rocks Logan gave the name of Laurentian. For some time afterwards the same name was also applied to the somewhat similar rocks which were found to underlie the Cambrian formation in Britain, but it was felt safer to give the English rocks a more general name. They are therefore now usually called Pre-Cambrian, which simply means older than the Cambrian strata, or Archæan.

In Canada the total thickness of the Laurentian, PreCambrian, or Archæan rocks is now estimated at 50,000 feet. In Britain it is nothing like so great as this (though still considerable); but the thickness of these extremely old and altered rocks is a very difficult matter to determine, for all signs of the original stratification in them have often been destroyed, and the rocks have been so bent and folded that it is possible the same beds may have been measured more than once in the same section.

It will be understood from some of the foregoing sentences that the task of dating or classifying these early rocks is one which is far from simple, and which has given rise to many different opinions. We may here give another example. "During the years between 1831 and while Sedgwick was occupied in studying the rocks of North Wales," writes Mr. W. Jerome Harrison, "another

good example of a foliated rock. It is composed of the three minerals, quartz, felspar, and mica, arranged in this foliated manner. Mica schist, talc schist, and other rocks have a similar structure, and are sometimes briefly called "schists." 


\section{FAMILIES OF ROCKS}

geologist, Mr. (afterwards Sir) Roderick Murchison, was engaged in the examination of the strata which occupy the south-east of Wales and the adjoining border counties of England. To these rocks Murchison gave, in 1835, the name of Silurian, from the ancient British tribe of the Silures, who inhabited that part of the country when the Romans invaded Britain." Later in last century, in order to distinguish more clearly the periods of the rocks which began or ended in these areas, the name of another ancient British tribe was called into requisition-the Ordovics; and thus for certain strata which were neither Silurian nor Cambrian Professor Lapworth proposed the name Ordovician.

Let us, however, now leave these geological controversies, enthralling as they are to those who have taken part in them, to consider briefly what was the aspect of the earth during the ages when these rocks were being laid down. The earliest rocks do not generally contain fossils, though there is no doubt that life existed during the later part of the time when they were laid down. The few fossils that have been preserved are those of crustacea (the species from which shrimps, for example, are derived), and there are certain tracks of two kinds of burrowing worms. It is noticeable that crustacea, the oldest definite fossils yet found, belong to a family which is well up in the animal kingdom, and therefore we know that lower forms of life must have been long in existence. Since we can only draw conclusions of the climate of a period from its fossil remains, and as these fossil remains are so scarce, we camnot say really any- 


\section{AND THEIR DESCENDANTS}

thing of value about the world's climate in the earliest eras.

When we come to the Cambrian, however, we are on firmer ground. In the Cambrian rocks there is, for the first time, a fair preservation in fossil form of the life of the period. Even here the record is far from complete, but it is an immeasurable advance on the records of previous periods. The most striking thing about this comparatively plentiful appearance of life is that while the animal kingdom is fairly well represented the plant remains are hardly to be recognised at all. Yet there must have been plants if only to feed the animals, and we have very good reasons for believing that the surface of the land was clothed with some form of vegetation. Not a few of the Cambrian animals were fixed to the bottom of the sea, and therefore there must have been enough matter of some organic kind floating in the water to bring them their daily food. Possibly many of the plants were of the minute kind which forms scum on rivers and ponds, and so would not readily leave fossil impressions. Turning to the record of animal life, it appears that nearly every division of the animal kingdom, except such as had backbones, had some kind of a representative in Cambrian times. Crustaceans, molluscs, worms, corals, jelly fish, sponges, quite a large variety of seaanimals, suddenly make their appearance, and although no traces of land animals have yet been found, we have reason to believe that some land animals may have existed. Our reason is that in the next era but one (Silurian) scorpions and insects appear, and these are 


\section{FAMILIES OF ROCKS}

such highly developed forms of land-life that they probably had some primitive ancestors in the Cambrian. No real fish have been found in the Cambrian rocks, but they appeared in the next era (Ordovician). It is the trilobite which is the characteristic animal of the Cambrian times. They were crustaceans; they had eyes; and they gave the promise of development; but there is no reason for believing that they were as high in the order of creation as the commonest lobster of the sea-shore. Nothing remains to us of them except their bony structure, but we believe that they could both swim and walk on the sea-bottom ; that some were swift of morement, and that they acquired the habit of moulting their shell. They may have been sociable animals, for the shells of trilobites are sometimes found together in large numbers, occasionally closely packed, "spoon fashion," and though these may be moulted shells, we are warranted in supposing that the early trilobites lived in colonies, hunted for food, and made war like their descendants millions of years after. What were the actual conditions of life in this world of Cambrian days we do not know positively. The first beginnings of life, the simple one-celled plants, may have first dwelt in the deep ocean. The land was barren, its lakes unfitted to support life. On the other hand, it is equally likely that the first begimings of life may have been the simple plants growing in inland waters and gradually spreading down to the sea. We do not know, but it is most probable that life began in some great body of water, where plants and insignificant animals grew together, perhaps fought together, 


\section{AND THEIR DESCENDANTS}

and certainly in this environment became more and more fitted for the business of living.

In Mr. Henry R. Knipe's scholarly and well-informed volume, Nebula to Man (J. M. Dent \& Co.), to which we are indebted not only for several of our illustrations but for many extremely valuable suggestions, the struggle for existence in the early ocean is well summed up :-

Thus through the brine life manifold proceeds,

Impelled to higher states by growing needs ;

Aud all these early life-types in the seas

Will branch in time to many species;

And some amid conditions too severe,

Must, after stress and struggle, disappear.

And when a species falls from Life's domain

It never gains a place on Earth again.

We may speculate with some approach to certainty on the general appearance of the earth in those days. There was far more water on the surface of the globe; the land surfaces were small and infrequent. The seas may have been shallower than those which we know, but they were far greater in extent. There must have been far more rain and a very much greater number of violent storms arising from the constant condensation of the waters by the rays of the sun. The sun was probably seen far less often in those days, and there are some geologists who believe the earth to have been perpetually covered with cloud, as the planet Venus is now.

Europe as a continent did not exist. A few islands showed their heads above the waves where Germany and Switzerland, Eastern France and Spain now stand. Scotland's rocky islets were probably visible, on the ex- 


\section{FAMILIES OF ROCKS}

treme west, though these islands were destined to sink again below the wave's. Thence the ocean stretched without a break, as at present, to Canada. A great part of Canada's bleak lands was above the waters; but the United States, except for a few great islands, were submerged. In the southern hemisphere South America, split into numerous long reefs and islands, gave promise of the continent to be; and there were great stretches of land over Brazil, extending to the west where the great chains of mountains now rise. Asia was largely covered with shallow waters, and the whole extent of the northern plains of Africa was sea. So far as we are able to judge the distinctions of climates were less marked then than now, and the conditions seem to have been much more uniform over all the northern hemisphere. This equality of climate lasted into the next or Ordovician period.

The Ordorician period grlides insensibly into the Cambrian. There was no distinct break in the succession of life. The species seem to have slowly extended and developed from one of these great periods into another. But the life of the Ordovician era, which has been preserved for us, is much more abundant. Land was beginning to emerge from the sea in greater bulk; life was springing up on the lind and was emerging from the sea, perhaps to take up its habitation there. The first insect life appears in the Ordovician. It is not an imposing relic except when seen through the eye of imagination. It is just an obscure wing of an insect which was found impressed on some shales found 


\section{AND THEIR DESCENDANTS}

in the upper Ordovician rocks of Sweden, and all we can say of it is that it belonged to the same class of insects as lady-birds. The existence of this insect shows that there must have been land vegetation and an atmosphere which was suited to active air-breathing things. The other appearance of great interest in the Ordovician rocks is that of the first fish. They were found in Colorado, but they are very much shattered and tell us very little about the animals they represent. These fish were covered with plates, and were evidently thus defended against attack, so that we may surmise the existence of some other animal that preyed on fishes. Whether these fishes were themselves ferocious we cannot, however, say. But that which was the chief characteristic of the Ordovician era was the climax of the trilobite. More than half of all the known trilobites were present in Ordovician times. Only a few of these came over from the Cambrian, while the others make their first appearance in this period. In the next period (Silurian) their numbers fell to one half, and in later periods declined still further, till they disappeared altogether at the close of the Palæozoic era. Some of these curious animals appear to have been able to move very quickly; others would roll themselves up like hedgehogs to defend themselves against attack; and some of the larger ones were from eighteen inches to two feet in length. Next to these in interest were the cephalopod types, marine animals, that may have resembled the swimming nautilus of to-day in some of their developments. They attained to enormous sizes, some of the shells being twelve to fifteen 


\section{FAMILIES OF ROCKS}

feet in length and a foot in greatest diameter. From this maximum they ranged down to forms smaller than a pipe-stem. Their habits are to be gathered only from their structure and from the habits of their relations in the present seas. Perhaps they floated, shell uppermost, or crawled upon the bottom and preyed on a rariety of the weaker forms of life. There appear to have been fewer worms, perhaps because the muddy and chalky sea bottoms of the Ordovician period were less congenial to them than the Cambrian sands.

The changes in the structure of the earth's crust which brought the Ordovician period to an end marked also the begiming of the Silurian period. 'These changes affected sometimes small areas and were very intense; sometimes they affected larger areas more slightly. It must not be assumed, however, that these changes were necessarily sudden or violent. In examining the rocks now, we see merely the effects, and of these effects it is the more remarkable alone which have survived the march of ages. There was more water on the earth's surface then than now; and side by side with continuous storms of tropical violence, it is extremely likely that volcanoes and earthquake movements were more frequent and more considerable in their effects. The tide of morement by material things may have been faster; and certain it is that the land was now lifting itself up above the shallow seas. Mountains were being built along the coast-lines; behind the const-lines the continents were shouldering their way upwards in large lind areas. North America began to show in this period the first 208 


\section{AND THEIR DESCENDANTS}

signs of becoming a continent; Europe's countries, or some of them, assumed a distinct existence. IVith the advent of mountains came streams and rivers; and the streams, fed by the abundant rainfalls, rushed down to the seas in torrents that performed the work of erosion with a rapidity perhaps unequalled by even the greatest rivers of our present-day knowledge-though at first the land areas were not large enough to give rise to streams as long as great rivers like the Amazon or Mississippi. We cannot say exactly what the areas and localities of the water and the land were; but it is safe to assume that at the beginning of the Silurian period beds of sediment brought down by the rivers and the rain were accumulating about the borders of the land, and as far out as the waves and currents were able to convey the earth materials. The climate was still equable and was much the same orer great areas of the world's surface, for the forests of warm temperate latitude are, in part, the same as those in Arctic regions. Certain parts of the land appear to have been desert.

Life began to change a great deal in Silurian times. The extensive withdrawal of the sea from great stretches of submerged surface reduced the area of shallow water available for the forms of life that had so richly peopled it during the Ordovician period. Then there came an age during which the sea invaded some of the regions of the earth's crust, and again withdrew, leaving behind it great stretches of water which gradually grew more intensely salt. All these things had naturally a great effect on the development of the plants and animals of 


\section{FAMILIES OF ROCKS}

Silurian times. We camnot in a brief summary of this kind do more than indicate some of the more conspicuous features. Corals hegan to spread through the clearer seas: and reef building on a grcat scale took place, generally some distance from the shores of the land. Other life in great abundance and variety gathered upon or about these reefs, and they became rich depositories of the animals of their day. The Crinoids, which, though animals, are sometimes called the lilies of the sea, developed strongly; sea urchins appeared, and forms akin to barnacles. The ancestors of the pearl oyster and the mussel date from silurian times; and so do the first Ammonites, those creatures known to the youngest collectors of fossils, and deriving their names from the Canaanitish god Ammon, which had a ram's head. Sea scorpions, sand fleas, king crabs, sea squirts, and worms and fishes of various kinds haunted the Silurian seas. 'The Silurian fish were most of them armed for defence, some with plates of bone; some of them had their tails stiffly joined to their backbones; some had skin like a prickly pear; some were not unlike the modern shark. The plants have left us many recurls-liverworts, ferns, and club-like mosses. The growing vegetation gave a new impulse to insect life-plant-lice and cockchafers and the scorpions we have named: and the vastness of their numbers is shown by the fact that they have outlasted the changes and vicissitudes of a myriad generations.

We may conclude this chapter by saying what we imagine of the general appearance of our own islands to have been. At the close of the Silurian period Britain 


\section{AND THEIR DESCENDANTS}

was probably an archipelago, ranging over ten degrees of latitude, like many of the island groups now found in the great Pacific Ocean; the old gneissic hills of the western coast of Scotland, culminating in the granite range of Ben Nevis, and stretching to the Southern Grampians, forming the nucleus of one island group; the South Highlands of Scotland, ranging from the Lammermuir Hills, another; the Pennine chain and the Malvern Hills, the third and most easterly group; the Shropshire and Welsh mountains, a fourth; and Devon and Cornwall stretching far to the south and west. Every spot of the island lying now at a lower elevation than 800 feet above the sea was under water at the close of the Silurian period, except in those instances where depression by subsidence has since occurred. 


\section{CHAP'TER XVIII}

\section{HOW THE COAL BEDS IVERE LAID DOWN}

I following the history of the rocks, we shall have presently to speak of that period which embraces the strata which contain coal. The geologists who lived in the early part of last century-William Smith and others-noticed that beneath the coal-bearing strata there lay a considerable thickness of red sandy beds containing the remains of fresh-water fishes, shells, and plants, while above the coaly strata they found another thick mass of red sandstone. To the lower and older red rocks they consequently gave the name of OLD $R_{\mathrm{F} 1} \mathrm{~S}_{\mathrm{AND}}$ STONE, and to the upper and newer ones the name of the New Red Sandstone. The Old Red Sandstone formation, therefore, lies between the Silurian rocks below and the rocks of the coal period above. But in Devonshire we find a considerable thickness of shales, slates, and limestones containing marine fossils, and these also lie between these two formations, and must therefore be somewhere about the same period, or geological age, as the Old Red Sandstone. The name "Devonian" has therefore been given to these shales, slates, and limestones, which 


\section{THE COAL BEDS}

were evidently being deposited in an open sea at or about the same time at which the Old Red Sandstone strata were being laid down on the floors of inland fresh-water lakes.

In the west of England the Old Red Sandstone stretches from Hereford and Monmouth into the neighbouring Welsh counties of Brecknock and Glamorgan. It is here at its greatest thickness of nearly two miles. The lower part consists of red and yellow sandstones, marls, and shales, with a certain kind of limestone concrete. The red colour is due to iron, and wherever this is abundant fossils are scarce, though remains of fishes have been found in it. Scotland is the classic ground of the Old Red Sandstone, for it was here that Hugh Miller, when a working mason at Cromarty, first collected its wonderful fossil fishes. Hugh Miller's discovery is one of the romances of geological annals. "Let any one picture to himself," wrote the late Mr. Bristow, "the surprise he would feel should he, on taking his first lesson in geology, and on first breaking a stone-a pebble, for instance, exhibiting every external sign of a water-worn surfacefind, to appropriate Archdeacon Paley's illustration, a watch, or any other delicate piece of mechanism, in its centre. Now this, many years ago, is exactly the kind of surprise that Hugh Miller experienced in the sandstone quarry opened in a lofty wall of cliff overhanging the northern shore of the Moray Frith. He had picked up a nodular mass of blue Lias limestone, which he laid open by a stroke of the hammer, when, behold! an exquisitely shaped Ammonite was displayed before him. It is no. 


\section{HOW THE COAL BEDS}

surprising that henceforth the half mason, half sailor, and poet, became a geologist. He sought for information, and found it ; he found that the rocks among which he laboured swarmed with the relics of a former age. He pursued his investigations, and found, while working in this zone of strata all around the coast, that a certain class of fossils abounded; but that in a higher zone these familiar forms disappeared, and others made their appearance.

"He read and learned that in other lands-lands of more recent formation-strange forms of animal life had been discovered; forms which in their turn had disappeared, to be succeeded by others, more in accordance with beings now living. He came to know that he was surrounded, in his native mountains, by the sedimentary deposits of other ages; he became alive to the fact that these grand mountain ranges had been built up grain by grain in the bed of the ocean, and the mountains had been subsequently raised to their present level by the upheaval of one part of its bed, or by the subsidence of nuother. . . ." The Old Red Sandstone, a book which was the result of Hugh Miller's researches, is a geological classic.

There are three other regions in England and Scotland where the Old Red Sandstone is conspicuous, and all of them were probably old fresh-water lakes of great extent in which sands accumulated. Sir Archibald Geikie has named them the Welsh Jakc, Lake Cheviot, Iatie Caledonia, Lake Arcalie. Iate Lorne. There are similar sandy deposits in Russia, in North Anerici, near the Catskill Mountains, and in many parts of 


\section{WERE LAID DOWN}

Canada; and there is little doubt that in all these places there were great lakes which gradually became the depositories of rivers and developed a life of their own.

The most remarkable fossils of these deposits were the fishes. The fishes began to appear in the later Silurian: they are strikingly abundant in Devonian times. The most remarkable of them are fishes which are only just like fishes after having been developed out of, or perhaps descending from, some other form of life. These fishes are now called the Ostracodcrm group, and they bear strange resemblance to some of the trilobites and the king crabs of previous eras. The Pteraspis is one of the earliest of these strange creatures, and its "fins," very much developed, were used as oars. Perhaps the most curious of all these strange creatures were the Ptcrichthyds or winged fish ; though it is not at all likely that the appendages we call wings were used for aerial flight. These fishes were all small; their forms were clumsy and their powers of moving about small. They had poor mouths and eyes, and they probably ploughed the soft bottoms of the sluggish waters, above which little besides their peculiarly placed eyes and the backs of their plated bucklers were habitually exposed. Another strange class of fishlike creatures was represented by a little creature which was found in Scotland and is sometimes supposed to be the ancestor of the lamprey.

Besides the fresh-water fishes there were some which dwelt in the sea; but in the Devonian era the fresh-water fishes were far more numerous. We cannot mention them all. The fish called Coccosteus and its allies had great bony' 


\section{HOW THE COAL BEDS}

plates of considerable thickness on its head and shoulders (some fine examples are to be seen at the Natural History Museum, Cromwell Road, London), but its tail and middle body were left unprotected. 'The sharks of to-day had their representatives among the Devonian fishes. Sharks have throughout geological time nearly always been seadwellers, though they still occasionally live in fresh water, as in Lake Baikal in Siberia and Lake Nicaragua. It seems clear, however, that in the Devonian period they lived in the open sea. But their remains are found in the Old Red Sandstone, and therefore it is likely that they lived in fresh and brackish waters also. In the same strata as these remarkable fishes there are found some large and peculiar crustaceans, something like our modern king crabs, but reaching the enormous length of six feet. There have also been mussels found and a few water plants, but not many.

In the Devonian relics the land regetation has for the first time been fairly well preserved. 'The huge club mosses made good their tenure on the land; and along the flats and low-lying lands by the rivers there were dense brakes of reedy calamites and masses of true ferns. The club mosses and the calamites diminished from their giant size eventually, but the ferns went on increasing, and ancestral types of the pines and the yews began to appear. The regetation of Devonian times was sombre; there could have been no flowers, and the insects were not of the kind that speed from bloom to bloom. Insects there were, gigantic dragon-flies and insects akin to the many flies that haunt the water; but the myriad buzz of 


\section{WERE LAID DOWN}

insect life as we know it in field and forest was not yet heard. It is rather an interesting fact that unmistakable evidence has been collected of the existence in Devonian times of those smallest of living things, the bacteria.

Of the general distribution of the land we cannot speak with great certainty. The violent disturbances of Silurian times seem to have ceased, but movements of the land did not cease. Great parts of England were rising from the water, and stretching out above the waves to Belgium and Northern France. There was no German Ocean and no St. George's Channel at the end of the period; and Scotland, also rising above the waves, was accumulating deposits of volcanic ash and lava. While, however, the British Isles and great parts of Belgium, Denmark, Scandinavia, and Western Russia, and smaller areas in mid-France, mid-Germany, and the Balkans were rising the rest of Europe was submerged beneath the waters. In the United States there were similar risings and sinkings of the land, but, on the whole, the course of geological history seems to have been more peaceful across the Atlantic. In Europe, as in America, there do not seem to have been notable changes at the end of the Devonian, though there was some alteration in level in Russia, Bohemia, and Great Britain. The rolling waste of waters south of the Bristol Channel began to deepen.

The continental area in which the Old Red Sandstone lakes lay (a kind of far Western Europe without a Russia) began now to sink in its turn. All of the British Isles, except a very thin slice just cut across the Midlands 


\section{HOW THE COAL BEDS}

from North Wales to Norfolk, was sunk beneath the sea. The lakes disappeared, and above their deposits, as above the rest of England and nearly all Europe except Scandinavia and patches of Spain, Italy, and the Balkans, a deep ocean rolled, and for many thousands of years deposited a grey ooze of limestone. This limestone is called the Carboniferous or Mountain Limestone. But as time went on this old sea floor began to be slowly raised, and in the shallower waters a great quantity of coarse sand and stones and conglomerate-the Millstone Grit, as it is called-was deposited. Limestone denotes clear seas; but the borders of clear seas are often the sites of accumulation of land rocks, and the clear waters of the early Carboniferous sea which stretched from Ireland to the north of Europe were bordered by shores along which mud and shale, gravel and sand were deposited.

The end of this period was marked in Europe by great disturbances of the earth's crust-though perhaps these disturbances, as we have shown in a previous chapter, were not sudden or violent, but were slow upheavals, lasting hundreds of thousands of years. It was at this time that a great system of mountains, sometimes referred to as the Palrozoic Alps, began to rise. This system of mountains crossed the central part of Europe from the Western Islands to the Sudetes Mountains in the east. Their remnants are seen in the Vosrges Mountains, the IIartz Mombains, and the Black Forest at the present time; and the development of the Iral Momtains was contemporaneous with them. During this time a mild 


\section{WERE LAID DOWN}

climate spread all over Europe, and as far north as Spitzbergen the waters were warm enough to support coral reefs and plants which we associate with the seas of genial latitudes. In time the Carboniferous sea became quite filled up; and its floor was raised up to or a little above the waters. Then in great swamps, marshes, and low lands, the burgeoning vegetable life of the northern hemisphere entered on its long-deferred reign. It was then that the coal which we burn in our grates to-day was laid down. Let us consider the circumstances in which coal is to be found. The coal formations, as we know them, are found in the same state, and evidently laid down in the same era, from the Equator up to Melville Island in the Arctic regions, where in our day it is always freezing. They stretch from Nova Zembla to the middle of China; and they are much the same in New Zealand and New South Wales. Therefore the first conclusion we draw was that nearly all over the globe the climate was the same-hot, close, moist, muggy. Whatever the climate was the growth of vegetation was tremendous.

We shall have presently to say a little more about the vegetation; but for the present we need only say that it was very different from the vegetation with which most of us are familiar. Imagine a hot, damp atmosphere, a kind of perpetual warm fog through which the rays of the sun struggled with difficulty, and where rain fell on most days of the year-a perpetual steaming hothouse. There was little variety in the appearance of the vast forest swamps. It certainly possessed, wrote Louis 


\section{HOTV THE COAL BEDS}

Figuier, the advantage of size and rapid growth; but how poor it was in species-how uniform in appearance! No flowers yet adorned the foliagre or varied the tints of the forests. Eternal verdure clothed the branches of the Ferns, the Lycopods (club mosses), and Equiseta, which composed to a great extent the regetation of the agre. 'The forests presented an innumerable collection of individuals, but very few species, and all belonging to the lower types of vegetation. No fruit appeared fit for nourishment; none would seem to have been on the branches. Suffice it to say that few land aninıls seem to have existed yet; while the regetable kingdom occupied the land, which at a later period was more thickly inhabited by air-breathing animals. A few winged insects gave animation to the air while exhibiting their variegated colours; and many mollusca (such as land-snails) lived at the same time.

Ultimately all this richness of regetation became by decay, by compression, by submergence, perhaps by being buried under earthquake movements and volcanic outbreaks, converted into coal; and we may now ask how long did this process take. A rigorous growth of regetation has been estimated to yield annually about one ton of dried vegretable matter per acre, or 640 tons to the square mile. If this annual growth of vegetable matter were all preserved for 1000 years, and compressed till it was as dense and heary as coal, it would form a layer about seven inches thick. But a larige portion of the vegetable matter even in peat bogri cscapes as gas in the making of coal. Four-fifths of it escapes in this way. 


\section{WERE LAID DOWN}

If this be true the seven-inch layer would be reduced to less than one and a half inches, and a layer a foot in thickness would require between 8000 and 9000 years. The aggregate thickness of coal is frequently as much as 100 feet (when all the thicknesses of the seams are added together), and sometimes as much as 250 feet. At the foregoing rate of accumulation periods ranging from $1,000,000$ to $2,500,000$ years would be needed for the accumulation of such thicknesses of coal. It must be borne in mind that much depends on the rate of growth of Carboniferous vegetation, which may have been, and probably was, much more rapid than any we know outside tropical forests. On the other hand, we have been speaking of the aggregate thickness of the coal beds only. The greater part of the coal-bearing strata consists of shale and sandstone with layers or seams of coal like streaky bacon. Of the shale and sandstone there are thousands of feet, even where the sediments are fine and their accumulations therefore probably slow. For, as we have said, this was a period of great change, in which the forests were always sinking and rising again, being submerged by lakes, being covered by the sea, and again emerging as islands, to be overrun by vegetation.

As sinks some sylvan scene in all its pride Changed to lagoons of overflowing tide, Assiduous labours Land to win again

Her leafy breadths, invaded by the main. Down bring the rivers to the flooded shore Cargoes of shale and silt that slow restore The sunken glebes, till they again can hold Thick ferny brakes, and forests as of old.

(H. R, KNIPE。) 


\section{HOW THE COAL BEDS}

It would hardly seem unreasonable to suppose that these depositions, and the changes that brought them about, might have occupied as much time as the formation of the coal beds. This would double the figures, and make this period last something between two million and five million years.

In the coal as we know it are the remains of great forest trees; gigantic tree-ferns for the most part, and of many small plants forming a close thick sod, partially buried in whole countries of marsh land.

Every one knows those marsh plants, which bear the vulgar name of "mare's-tail." These humble plants were represented during the coal period by trees from twenty to thirty feet high and four to six inches in diameter. Their trunks have been preserved to us : they bear the name of Calamites.

The Lycopods of our age are humble plants, scarcely a yard in height, and most commonly creepers; but those of the ancient world were trees of eighty or ninety feet in height. Their leaves were sometimes twenty inches long, and their trunks a yard in diameter. Such are the dimensions of some specimens which have been found. Another Lycopod of this period attained dimensions still more colossal. The Sigillarias sometimes exeeded 100 feet in height. Herbaceous Ferns were also exceedingly abundant and grew beneath the shade of these gigantic trees. It was the combination of these lofty trees with the undergrowth of smaller regetation which formed the forests of the Carboniferous period. "What could be more surprising," exclaims Figuier, "than the 


\section{WERE LAID DOWN}

aspect of this exuberant vegetation, these immense trees, these elegant arborescent ferns with airy foliage, fine cut, like delicate lace. Nothing at the present day can convey to us an idea of the prodigious and immense extent of never-changing verdure which clothed the earth, from pole to pole, under the high temperature which everywhere prevailed over the whole terrestrial globe. In the depths of these inextricable forests parasitic plants were suspended from the trunks of the great trees, in tufts or garlands, like the wild vines of our tropical forests. They were nearly all pretty, fern-like plants, they attached themselves to the stems of the great trees, like the orchids of our times." The margin of the waters would also be covered with various plants with light and whorled leaves, belonging, perhaps, to the Dicotyledons. Before leaving the subject of the plants of the coal measures, we should perhaps mention as one of the most interesting discoveries of the present generation that whereas the links between the fern-like trees of those days and the cycads, or early group of seed-bearing plants, were for long missing, they have been found by the researches of Professor F. W. Oliver, F.R.s., who has identified in the Lyginodendron a seed-bearing fern from the conl measures.

We must now turn to the less interesting but not less important topic of the animal life of the Carboniferous period. At the beginning of the period when only a small portion of the British Isles was above the waters, and an ocean rolled from Ireland to China, the life of which the must important relics were left was that of the 


\section{HOW THE COAL BEDS}

sea. In the early Carboniferous seas the rhizopods, some small as dust, laid down with their tiny shells the foundations of mountains yet to be; the "sea lilies" were at the height of their pride, occupying vast areas in the flowing tide; forms like the present-day nautilus began to appear, and the "lamp-shells" attained their greatest size. The trilobites, hitherto the most conspicuous and noticeable animals of the earth's childhood, were beginning to die out, vanquished in the struggle for life by more adaptable forms, and the big sea scorpions were waning fast. The king crabs and the water fleas still throve, and the fishes, though most of them not very large, were growing larger, some of them taking the appearance of the dog-fish, some of the ray, some of the shark; and, what is more important than the fact of size, the fishes were growing speedier and more capable of attacking weaker creatures.

In the course of these ages the sea invaded the land; and shores where land-snails and millipedes and centipedes, beetles and scorpions, spiders and cockroaches had found a home became entirely changed, not only in their appearance and character, but in the type which subsisted on them. It is possible (for something of the kind has been noticed in our own days in the West Indies, where a sea-crab species is showing signs of becoming a land animal) that some of the forms of water animals became used to living in shallower and shallower water as the generations went on till they became partly land and partly water animals-amphibians, as they are called. 'Thus small newt-like beings, 


\section{WERE LAID DOWN}

moving clumsily through the swamps, made their appearance, and others with stronger limbs pushed onwards through the forest. Others in form resembling snakes crept through the mud and lived among the swamps by the side of the sea. Not much is known of the food and life-habits of any of these amphibians. From their teeth we may perhaps judge that they lived on fish, crustaceans, insects, and on one another, and their predatory life sometimes led them to climb trees in search of food. What, however, is most important about the amphibian is that they were the pioneers of the march of those creatures which had backbones-the vertebrates -from the sea to the land. 


\section{CHAPTER XIX}

\section{THE AGE OF REPTILES}

$W^{n}$

$\mathrm{E}$ have already said that in the many hundreds of thousands of years which went by during Carboniferous times the sea sometimes advanced and sometimes receded, and nothing shows this better than the great thickness of the deposits in which the coal lies in seams. In America, as in Europe, Asia, Africa, Australia, and New Zealand, South and Central America, the Carboniferous system is found. In Arkansas, in North America, the coal measures attain the remarkable thickness of 18,000 feet; in the Wasatch Mountains the Carboniferous strata have been estimated to be 13,000 feet thick, and in silver-bearing Nevada 10,000 feet. The formations of the Western European coal measures, like those of Eastern North America, consist principally of shales and clays, with smaller amounts of sandstone and limestone. They attain great thickness, and, including 5500 feet of the Millstone Grit, are 13,500 feet thick in Lancashire and several thousand feet thick in many parts of Great Britain and Ireland. The extraordinary thicknesses show that near our islands must have been a very extensive and lofty area of land. In Germany the same strata, thickly seamed with coal, 


\section{THE AGE OF REP'TILES}

are 10,000 feet thick. There must also have been considerable volcanic or earthquake action as we know, because in Germany, near the Hartz Mountains and elsewhere, there are many igneous rocks thrust into the strata, and also because in Belgium and in France the coal strata are very much twisted and contorted. The same or similar beds are found in Siberia, in Japan, and in China, where the coal beds are said to be thicker than anywhere else in the world. The Carboniferous system is also found in Africa, in the north, south-east, and south of the continent; and in Australia and New Zealand Carboniferous strata to the thickness of 10,000 feet are indicated.

At the close of this period the changes ever taking place transformed the conditions of life in a way the reverse of that which we have hitherto been examining. So far each age has shown an increase of life on the age preceding it. But when the great outburst of carboniferous activity began to wane it was followed by a lessening of the wave of life. As we said in the last chapter, there lie on the top of the coal-bearing strata beds to which the older geologists gave the name of New Red Sandstone. But in 1841 the New Red Sandstone was divided into two distinct geological formations. To the lower and older part Murchison gave in 1841 the name of Permian (from Perm or Permia, an ancient kingdom in Russia, where red sandy rocks of this age form nearly all the surface), but in Germany it is more frequently called the Dras (from Lat. duo, two), because in that country it is composed of two well-marked 


\section{THE AGE OF REP'TILES}

divisions-red sandstones below and magnesian limestones above. Thus there are two types of this Permian formation: the Permian type proper-a mixed series of red sandstones, marls, shales, and limestones, with some thin beds of coal, as found in Russia; and the Dyassic type, as seen in Germany.

We do not know what brought about the change: though we do know that during it chere was great volcanic activity over Europe and that the waning forests of regetation and the steaming swamps gave place to desert plains. Vegetation sank lower and lower. The forests disapperred or dwelt only in clusters. The soft sappy trees gave place to hardy pines which clung to the plains and the mountains, and other sterner types began to appear, allied to the spruces, yews, and gingko. The gingko tree is one of the oldest of the tree type which now has a living representative. Any reader interested enough in the matter to walk along Royal Hospital Rond, Chelsea, will find a gingko tree just outside the Old Physic Garden; and of course a good many other examples are preserved in botanic gardens. The cycads, offshoots of the ferns, through the strange group of trees known as the cycado-filices, spread through the woods.

The trilobites, to turn to animal life, all but disappeared, though one elegint example remained; the corals were changing; and the lamp-shells were dropping out. There were a few new species of fishes, but none of any great strength or capacity, and all preserving still the tail which is part of the backbone. 'There was an allround impoverishment of life-so great, indeed, that the 


\section{THE AGE OF REPTILES}

early geologists used to believe that a complete destruction of all life followed this, the closing stage of the Palæozoic era, and that a re-creation followed. They would have been confirmed in this belief had they but known that intense cold and glaciation were setting in where the tropics were situated and that the dryness of vast deserts was sweeping away life elsewhere. But we now know that life was not entirely lost; that many species survived, and that others, altering to suit altering conditions, became stronger in the process. Nevertheless, life was greatly impoverished. A census made a few years ago gave the known animal species of the Carboniferous period as 10,000, while those of the Permian period were only 300, or three per cent. Possibly the percentage was larger than that, but still it was small.

But if the Permian was poor in life it was very interesting. The amphibians had been growing in strength during the later stages of the Carboniferous age, and may possibly have been more numerous then than at any other time, for the vast swamps were very favourable for them. They diminished in the Permian, though the Permian amphibians showed some advances, and began to assume a likeness to reptiles. Perhaps the reptiles may have first appeared in the Carboniferous, but they declared themselves in the Permian age. Two great branches of reptiles seem already to have defined themselves; perhaps they had never formed a common group as reptiles, but had separated while still amphibians. The one bore resemblance to, and were perhaps the forerumners of, the greai hosts of lizards, crocodiles, dinosaurs, 


\section{THE AGE OF REPTILES}

ichthyosaurs, and flying saurians, which are the most pronounced of the reptiles, and of which we shall have a great deal to say presently. The other group were perhaps the ancestors of the turtles and plesiosaurs which appeared later, and possibly led the way to the mammals. This rapid and diverse spreading out of the reptiles in a period when life as a whole was at a low ebb is not a little remarkable. These creatures seem to show the arrival of a more pronounced form of air-breathing animal; and that may have been the consequence of the presence of more oxygen in the earth's atmosphere. Of the Permian amphibians, one of the most interesting was like the Sphenodon, which still creeps about the northern islands of New Zealand. The most striking of the reptiles was the Naosaurus, a beast-like creature with a high back of spines webbed together like a solid porcupine. It was from three to ten feet in length.

All these changes were brought about by the general withdrawal of the sea, both in the North American continent and in Europe. In both continents there are beds which accumulated fresh water; in both beds which were laid down in salt lakes or inland seas; and in both beds which were laid down on the floor of seas washing the continents. Great areas seem to have been sometimes dry and sometimes submerged; other and greater areas, bordered by ice and sometimes swept by icy blasts, or subject to burning sun in summer, were deserts such as we are aware of now in Asia or North Africa or midAustralia, but much larger in extent than any of these. It was in conditions such as these that the ancient 


\section{THE AGE OF REP'TILES}

or Palæozoic rocks came to an end and the Mesozoic or Middle Period began.

The Middle period of strata and of the life which those strata have preserved has usually been separated from the older rocks because, owing to the great period of arid desert conditions, the character of life changed a great deal; but fuller knowledge shows that the links were still there, and that ceaseless adaptation of animals to their surroundings was ceaselessly going on. We need not follow closely all the changes and relationships, and only much greater knowledge than geologists yet possess will enable them to trace all the alterations of the land and sea. But we may trace the alterations in the appearance of the continents in broad outline. Nearly the whole extent of the British Isles was now above the sea, and was enjoying a climate perhaps as cold as present-day Iceland. 'To the south and east of Scotland was a great shallow inland lake, while north of Great Britain a huge plain stretched across Europe. To the south of the lake was a belt of land, and farther south still the sea had invaded Italy and reached to Southern Germany, and in this sea was being laid down the limestone which in later eras was to be elevated into the mountains of the Apennines, the Alps, and the Pyrenees. North Africa was under water, but farther south the uplifted lands were joining hands with India. Sea swept part of Asia, but North America was larger and broader than it is now, her western coast stretching farther out into the ocean.

In this period, which is called the Triassic (the name given to it by the German geologist Bromn because of the 


\section{'THE AGE OF' REP'TILES}

three distinct beds he found in it, though the middle of these, a shelly limestone, does not exist in Great Britain), there was a wide development of large reptiles and amphibiuns. We cannot enumerate them all, for not one chicpter nor one rolume would suffice to deal adequately with the reptiles of the Trias formations and of the Jurassic rocks which followed them, and of the Permian which preceded them. But we may speak of some of them. One of the most striking was the Pareicusaurus, which has been found in the Jurassic sandstones and limestones of South Africa, of Russia, of India and Scotland, and of middle England. The skicleton of the Pareiasaurus looks like that of a gigantic pur dog eight feet long; but it was a comparatively harmless animal, the teeth of which show that it largely fed on regretable food.

In Sir E. Ray Lankester"s lectures on "Extinct Animals" he described the finding of a great many of these fossil reptiles by Professor Amalitzky on the banks of the River Dwina, near Archangel. There is a clifl of Permian strata on the banks of the Dwina, and in this cliff there is a peculiar pocket or accumulation of sandy matter with large hard nodules embedded in it. 'These nodules are removed and broken up for mending the roads. The pocket seems to be in a fissure and of Triassic age, later, that is to say, than the Permian rocks on either side of it. However that may be, the nodules are usually removed for road-mending, and four or tive years ago Professor Amalitzy on visiting the spot was astounded and delighted to find that 


\section{THE AGE OF REPTILES}

when broken each nodule was seen to contain the skeleton or skull of a great reptile. The Russian geologist determined to make a most thorough investigation of this wonderful deposit, and for years spent several thousand pounds in having the nodules dug out by the peasants after the year's farming work was over, and in removing them to the University of Warsaw, where with the finest instruments and greatest care the nodules are opened, and each bone removed in fragments is put together from its more or less broken parts, and firmly cemented and set up in its natural position as a complete skeleton.

These Pareiasaurs reconstructed by Professor Amalitzky were about as big as well-grown cattle, but not so high on the legs. Living at the same time, and its skeleton now found near them, was an enormous and truly terrible flesh-eating animal, with a skull two feet long and enormous tiger-like teeth. This creature was named Inostransevia. No doubt the vegetarian herds of Pareiasaurus, whose small peg-like teeth indicate their harmlessness, were preyed on by the terrible Inostransevia, as were their brethren in South Africa devoured by other carnivorous reptiles of that remote Triassic age. So we see the co-existence of blood-sucker and victim-of the destructive oppressor and the helpless oppressed-forced on our attention in these two localities, Russia and South Africa, in days long before man was. Other land forms were grotesque and curious in shape, the Chelonians for example, big birds and crocodiles rolled into one, and clothed in lizard-like skin-queer pear-shaped brutes with 


\section{THE AGE OF REPTILES}

huge hind limbs, short fore limbs, narrow chests, and pigmy skulls.

Both branches of the reptilian horde, those representing the saurians and those which were the forerunners of the mammals, sent delegations to the sea before the close of the Triassic period. The Ichthyosaurs represented the more pronounced reptilian line; the Plesiosaurs were the representatives of the coming mammals. It is not difficult to find good reason for this morement to the sea. Besides the inevitable tendency of every masterful race to invade all accessible realms, the renewed extension of the sea that set in during the Triassic period and became pronounced before its close, especially invited this, for the shallow waters creeping out upon the land with their now prolific life set tempting morsels before the voracious reptiles, on the one hand, while on the other, the reduction of the land area and the restriction of their feeding-grounds, intensified by the multiplication of the reptiles themselves, forced a resort to the sea. One of the reptiles of this period, the Lariosuurus, shows by its development how the change affected the reptiles. In the earlier stages of the Trias it resembled a rather swollen alligator with four limbs symmetrically situated and used for crawling. In the later forms of these reptiles the limbs were modified with paddles, and all power to move about on land was lost. 


\section{CHAPTER XX}

\section{THE AGE OF REP'TILES}

\section{(Continued.)}

\section{$\mathrm{T}$}

HE Triassic period in its later stages was very like the earlier period of the era which followed it, and the reptiles which were characteristic of the close of the first were continued in some cases with only slight differentiation in the second. The Plesiosaurs and Ichthyosaurs are associated with the Trias, and we may therefore describe them now. Though some of these large aquatic creatures must have measured thirty feet from snout to tail, they do not equal in size the great aquatic mammals of to-day-the whales. In life the Plesiosaur had a body like the hull of a submarine with four great paddles attached-the fore and the hind legs. It had a long neck like a gigantic swan, and an elongated head provided with powerful jaws armed with numerous pointed teeth. It probably could swim under water as well as on the surface, and when floating could snap small lizards from the land. The paddles have a definite structure like legs, with five toes, wrist or ankle, forearm or foreleg, and upper arm or thigh. A great number of these Plesiosaurs have been found in the Lias formation of the south of England; and slabs containing whole skeletons have 


\section{THE AGE OF REP'TILES}

frequently been obtained. They and two similarly embedded and flattened skeletons of different kinds of Ichthyosaurs may be seen in quantity on the wall of the gallery of fossil reptiles in the Natural History Museum at South Kensington.

'The Ichthyosaurs were much more fish-like or whalelike in form than the Plesiosaurs. "They were, indeed," says Sir E. Ray Lankester, "singularly like the porpoises and grampuses among living whales and stand in the same relation to land-living reptiles that the porpoises do to land-living mammals. Their fish-like appearance and fins are not primitive characters and do not indicate any closer blood relationship to fishes than that possessed by other reptiles. They are the offspring of four-legged terrestrial reptiles which have become specially modified and adapted to submarine life." Like many whales, they had a fin on the back devoid of bony support. The Ichthyosaur had a ring of bony plates supporting the eyeball (as birds also have), and these are often preserved in the fossil specimens.

At the end of the Triassic period some strata were laid down which have been called "Beds of passage." We have seen that the 'Triassic strata were probably deposited, altogether or in part, in extensive salt lakes or inland seas. At the close of the Triassic period the waters of the ocean were admitted to these areas by the sinking of the land at some point or other of their margins. With the sea-water came many living things-fishes, shells, etc.-and the very scanty life of the 'Triassic lake was replaced by an abundance of marine life. These beds were 


\section{THE AGE OF REPTILES}

called the Rhrtic beds because they were first found in the old Roman province of Rhætia, which occupied an Alpine district between Bavaria and Lombardy. Here they were thickest, 3000 feet of limestones and shales; but they have since been found either thicker or thinner everywhere in England, and in the United States, as well as in other parts of Europe wherever we can find the Lias lying on the Trias. They are especially interesting, because they contain the teeth of the earliest known traces of the highest division of the animal kingdom-the mammals. 'These early mammals belonged to the lowest of all the mammalian tribes-the Marsupials, or pouched animals, now so common in Australia. The little banded ant-eater of South America, which lives upon insects and is about the size of a rat, is probably something like the first mammal, the Microlestes, in habit and appearance.

Let us now return, however, to the reptiles of the Jurassic period. It is so called from the Jura Mountains which occupy the north-west of Switzerland, separating that country from France. They are composed of a thick series of clays, shales, and limestones, to which, in 1829, the name Jurassic was given by the French geologist Brogniart. It was soon found, however, that the lower rocks of this period were very different from the upper. The lower rocks were very shaly and clayey with thinnish layers of limestone. These were called Lias. The name Lias is derived from "layers"-pronounced broadly by the Somerset quarrymen as "lyers"-a very suitable name for the lower beds of the Lias especially, since the alternation of thin beds of limestone and of shale gives 


\section{THE AGE OF REPTILES}

to the rock a banded or ribbon-like appearance, which may well cause the workmen to describe it as occurring in "lyers."

To the upper Jurassic beds, which contained much more limestone and also occasional beds of sandstone, the name of Oolite was given. The Oolitic strata have a special interest for English geologists, for it was in them that William Smith, the west of England surveyor, first made out (about the year 1790) the order of succession of the strata, and by this was led to his great discovery that "strata could be identified by their organic remains," that is by their fossils. He noticed that some of the limestone beds of the strata we are about to describe consisted of small rounded grains, which made them resemble the roe of a fish-indeed, they were called "roestone" by the workmen. Hence Smith-when seeking a name for this set of stratabethought himself of the term "Oolite," which means "egg-stone" (Gr. oon, an eggr, and lithos, a stone). Where the grains are very large the limestone is called "pea-grit" or pisolite (Lat. pisum, a pea). Some beds which contain numerous and irregularly shaped fragments of shells, corals, etc, are called rag-stones.

The Jurassic strata of Great Britain were sediments laid down in warm seas surrounding an archipelago of which Dartmoor, Wales, and Cumberland formed some of the islands. The whole of Western Europe was sinking and had sunk; and the waters of the open ocean were admitted into and mingled with the salt mineral water's of the great Triassic lakes. The change 



\section{THE AGE OF REPTILES}

was at first very like what would happen at the present day if the coast of Palestine were depressed, so that the waters of the Mediterranean flowed into the Dead Sea. The few fish of the salt lakes were killed; and as the land continued to sink, the sea at last flowed all over Central and West England, bringing with it an abundance of marine life. But the reptiles were far from being finished with; and the progress of the small mammals was extremely slow.

First, as to the reptiles. The whale-shaped Ichthyosaurs continued to develop in the seas, and grew larger and larger till some of which we have found traces reached a length of forty feet. The long-necked Plesiosaurs also advanced from strength to strength, and some types grew larger. But by this time new breeds were developing, with shorter necks and larger heads (and consequently larger brain-power), which had a better chance of surviving in the struggle for existence than the unwieldy and slow-witted reptiles which preceded them. The Ichthyosaurs became more and more fish-like, and some of them developed the habit of breeding at sea instead of having to return to the land to deposit their eggs, as do the sea-going turtles and crocodiles. Descended from quite a different stock, the Plesiosaurs adapted themselves to sea life in their own fashion. Instead of adopting the flowing lines of a fish, the body took on a form more like that of a turtle, while the lengthened neck gave rise to the description applied to him since that they had the "body of a turtle strung on a snake." At their longest their necks 


\section{THE AGE OF REP'TILES}

had as many as serenty-six bones, or vertebra, which is more than any other animal living or extinct ever possessed. A smaller order of crocodiles appeared and flourished for a time; and the ancestors of the sea turtles, which were to enjoy so long a reign, began to make their first appearance.

Among the land animals the Dinosaurs" (or the "fearful " saurians) attained remarkable size and diversity, and their dominant species were easily lords of the reptile horde. They developed not only as Hesh-eating monsters, but also in vegetable-eating species. Of the flesh-eaters the Ceratosaurus was the most terrific. It was only serenteen feet long, but when standing on its powerful hind legs it could have looked in at most first-floor windows, and it used its cruel fore limbs for seizing and holding prey. Imagine a kangaroo with the teeth of a crocodile, the size of an elephant, and the ferocity of a tiger and you will have a fair idea of what you would have met in a Ceratosaums.

The vegetarian Dinosaurs first became known in this system, but their development was so extraordinary that they soon outranked the flesh-eaters both in size and diversity. Among these the Brontosaurus attined the extraordinary length of sixty feet, and possibly more. It walked on its four legs, and is one of the largest known of all land animals. This enormous creature in spite of all its size and bulk was yet rather weak than strong. Its general organisation was unwieldy; the heid was very small, and the brain hardly bigger than a walnut. 'The 1 From Gr. "deinos," fearful. 



\section{THE AGE OF REPTILES}

task of providing food for such a body must have been a severe tax on so small a head. The inconvenience of its bulkiness was perhaps reduced by living in and about water; but from the excellent preservation of some of the skeletons it has been thought that its life was often ended by sinking in some quicksand or shoal, from which its own massiveness forbade that the Brontosaurus should extricate itself.

Not greatly removed in habit or appearance from the Brontosaurus was the Diplodocus, a magnificent specimen of which has been set up in Pittsburg, and a fine replica, owing to the generosity of Mr. Andrew Carnegie, in the Natural History Museum. The Diplodocus, a harmless placid beast, was over eighty feet from the tip of his snout to the end of his enormous tail. It has been calculated that impulses travel along the nerves to the brain at the rate of about twelve yards a second. The rate may have been less in the case of the sluggish Diplodocus, but in any case it would evidently take at least two seconds for a nerve impulse to travel the length of this reptile; so that if any enemy attacked him at the end of his tail it would be two seconds before the Diplodocus would realise the fact, and perhaps four seconds before he could begin to turn round to defend himself. Even larger than these was the tremendous Brachiosaurus, who weighed as much as a steamengine and whose thigh-bone was nearly eight feet high. These were the largest reptiles ever known, and may be taken as reaching the point when bulk becomes a burden, and as signalising an approach to the limit of evolution in the line of size. Less bulky than these were the 


\section{THE AGE OF REPTILES}

Stegosaurs, which were also four-footed. They were curiously armoured, and formed a group of very remarkable creatures found in England and Westem America. While they were less gigantic than some of those we have just described, they found compensation in protective plates, spines, and similar modes of defence. A Stegosaurus found in Wyoming was probably the most hideous to look upon; but like his relatives he had an extraordinarily small head and brain, and was a sluggish creature depending on his ugliness and armour for protection. Very likely this small size of the brain of great extinct reptiles had to do with the fact of their ceasing to exist. Animals with bigger and ever-increasing brains outdid them in the struggle for existence.

It has already been noted that the crowding of the land may have led some reptiles to take to the sea. The same influence may have led others to take to the air and thereby escape the monsters of the swamps, jungles, and forests. Whatever the cause, the most striking and wonderful feature of this period was the development of flying reptiles. They had just been seen in the Trias. In the Jurassic they appeared fully developed. They doubtless sprang from some agile hollow-boned saurian, more or less akin to the slender leaping Dinosaurs. Between the ponderous Brontosaurs and the airy Pterodactyls was the most striking of contrasts. At first these bird-like reptiles were small, but later their wings had a spread of as much as twenty feet, reritable flying dragons. They were not adorned with feathers, but like bats had leathery membranes stretched from the fore limbs to the 


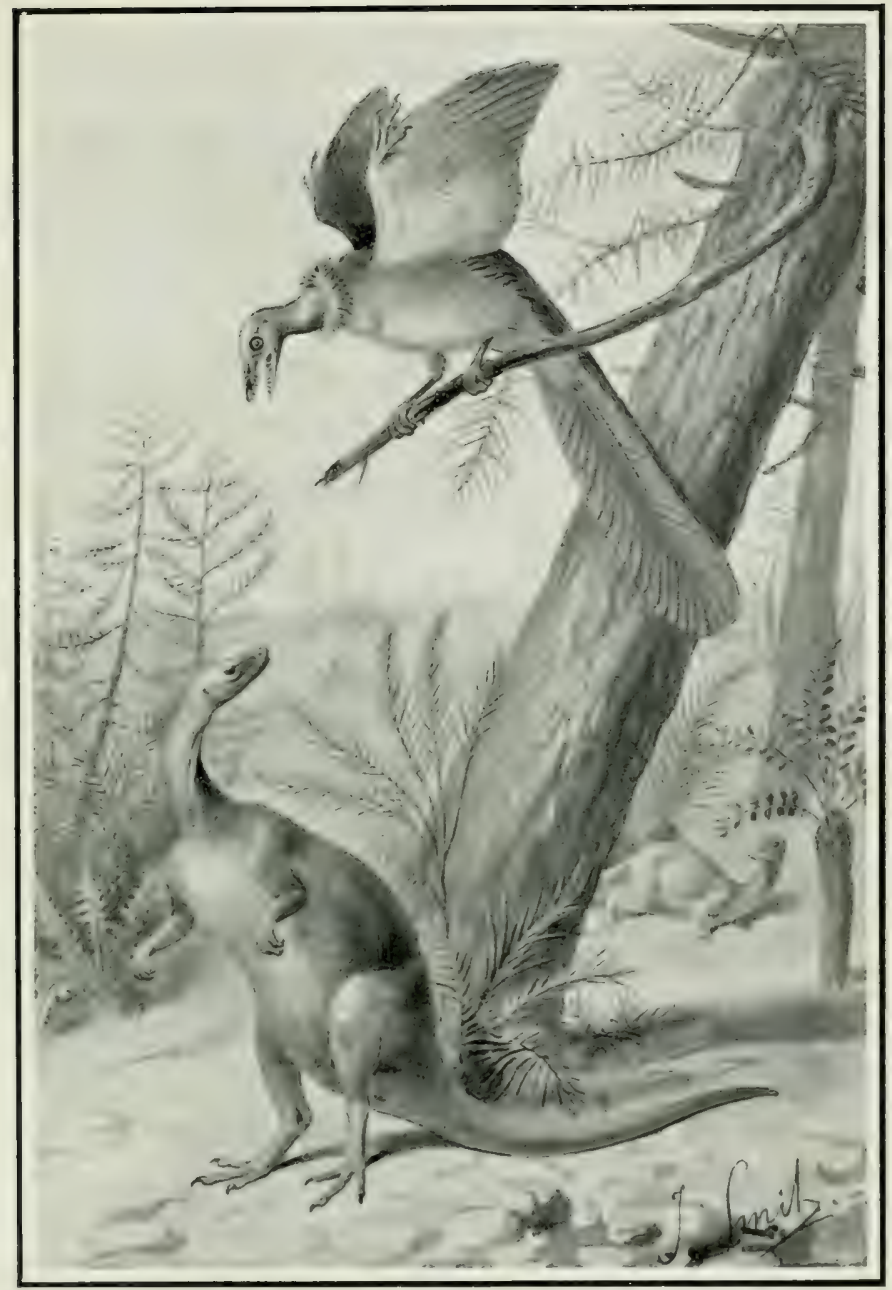

ARCH EOPTERYX (the earliest known fossil bird), and Compsognathus (a small Dinosaur) 



\section{THE AGE OF REPTILES}

body and to the hind limbs. Their heads were bird-like, and their jaws at first were set with teeth. They had true powers of flight, as is shown by the discovery of their remains in places where they must have been far out at sea when they sank and were buried. Later Pterodactyls had no teeth, and were, perhaps, milder in habits.

It seems natural to pass from the fossil reptiles to the birds. But as a matter of fact the birds are not very closely related to the Pterodactyls, and seem to have been descended from some other very special form of reptiles, so peculiar as to be considered a distinct class. It may actually have been descended from those reptiles among the Dinosaurs which walked on their hind legs and had only three toes to the foot. The first bird found belongs to Jurassic times; and its skeleton, found in some slate remains at Solenhofen in Bavaria, is now to be seen in the Natural History Museum. There is another one in Berlin. This bird, called the Archcopteryx, was of the size of a large pigeon, had a short head apparently without a beak, and its jaws were armed with teeth. Whereas living birds have the fingers of their " hands" tied together in their wings, this bird has three distinct fingers at the corner of its wings, each armed with a claw. Its legs were like those of living birds, and it had four toes. Its tail was unlike that of any living bird, and like that of a lizard. Whereas the bony part of the tail of living birds is very short and bears the tail feathers set across it fanwise, the Archocopteryx had a long bony tail made up of many bones, and the feathers were set in a series one benind the other till the tail looked like the 


\section{THE AGE OF REPTILES}

leaf of a date palm in shape. Strange as this little creature appears it was a genuine bird, for it had these feathers well developed, as the two fossil specimens showed. There are two sets of feathers forming the wings, and the thighs were also covered with feathers. 


\section{CHAPTER XXI}

\section{'THE CHALK PERIOD}

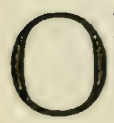

NCE again the European continent and with it Great

Britain began to sink. Great Britain at the beginning of the era which followed the Jurassic system, was joined to France, but south of this barrier was a great fresh-water lake, into which rivers and streams poured from the north and the east. Great forests grew on its borders, forests still crowded with ferns and cycads as in previous ages, but affording scope for pine trees to grow as well. On its borders flourished the giant Iguanodon, a great lizard-like animal which could raise itself on its hind legs and lift a fifteen-foot body so as to feed on the branches of the trees. The Iguanodon is a specially interesting fossil reptile, because it was one of the first to be discovered. The first bones and teeth of the Iguanodon were found seventy years ago by a celebrated and most delightful explorer of the earth's crust, Dr. Gideon Mantell, in the strata known as the Wealden, in Sussex, just below the chalk. Dr. Mantell was only a country practitioner, and when he first produced before the Geological Society his Iguanodon remains, and suggested that they were those of a reptile, some doubt was thrown on this conclusion, because geologists believed from the appearance of the teeth that the animal must be of some 


\section{THE CHALK PERIOD}

other animal family. But Dr. Mantell found that a little lizard living in South America had teeth like those he had discovered in his reptile remains, and he persisted in his view. Many years later a wonderful find was made near Brussels in a coal mine near Bernissart, the skeletons of no fewer than twenty-two huge Iguanodons were found complete and embedded in a fairly soft clay-like rock. The authorities of the Government Museum took charge of the place and most carefully removed the skeletons to Brussels, where the complete skeletons of seren were with enormous difficulty and care removed bit by bit from the rock and set up as entire skeletons in the Brussels Museum, where they may be seen. A replica of one of them is at South Kensington. The fore feet of the Iguanodon had five fingers, but the hind foot was very much like that of a bird, and had only three toes, and the bones of the pelvis or hip girdle were extraordinarily like those of a bird. When Professor Huxley examined the first fragments of the Iguanodon's remains he was inclined to believe them to be those of a gigantic bird; and it is generally believed now that it is from this extraordinary reptile stock that the birds were derived.

But the great lake with all its varied stores was doomed to sink lower and lower, till the great sea overwhelmed England. Another ocean joining it to the east overwhelmed Germany; and the whole of Europe, south of a line drawn through Scotland, Christiania, and Moscow, became sunk under salt water. 'There were patches standing up here and there-Ireland, Brittany, Cornwall, Spain or a good part of it, Switzerland, part of Italy (and also 


\section{THE CHALK PERIOD}

part of what is now the Western Mediterranean), and most of Turkey and Hungary. But elsewhere marine aninals succeeded the reptiles, and the foundations of all the chalk hills and cliffs of modern Europe were laid.

Of what were they made? We may borrow a capital suggestion from Mr. Jerome Harrison, of Birmingham University. "Take," he says, "a piece of chalk and brush it vigorously with a tooth-brush in a glass of water until the liquid looks quite milky. Allow the greater part of the sediment to subside, and then pour away the water and wash the material which has sunk to the bottom of the glass by pouring water on it two or three times. Put the whitish powder which finally remains under a microscope; and examine it with, say, the quarter-inch power, which will magnify about 300 diameters. The greater part of the white powder will then be seen to be composed of the minute shells of creatures called Foraminifera-little specks of jelly-like matter which secrete for themselves a shell or covering from the carbonate of lime dissolved in the sea-water in which they live.

"Countless millions of foraminifera inhabit the waters of the North Atlantic (and of other decp seas) at the present day ; and of these at least one species-Globigerina bulloides-cannot be distinguished from one of the commonest species found in the White Chalk. When these tiny animals die their soft parts soon decay and disappear, and their skeletons (or shells) fall on the sea floor, where they form a whitish mud or 'ooze.' The time required for the accumulation of so thick a deposit com- 


\section{THE CHALK PERIOD}

posed of the remains of organised beings-the White Chalk is in Norfolk quite 1200 feet thick-must have been very great. If we allow that the tiny shells of the foraminifera may have accumulated at the rate of two feet in thickness in a century, then it would have required 50,000 years to form the chalk of the southeast of England, whose thickness we have estimated at 1000 feet."

Every one who has been on a chalk cliff or hill has found, and perhaps thrown, chalk flints. Flints are made of mineral called silica, and very often these flints, or nodules of silica, surround some organism like a sponge or a shell. During the formation of the chalk the sea floor appears to have been covered at intervals by a growth of sponges, which were composed of siliceous matter, and their death and decay produced most of the flint. Sometimes flint is found in bands, in which case it may have been deposited by siliceous water trickling through fissures or cracks in the chalk.

In the sea which thus existed the Plesiosaurs and Ichthyosaurs still pursued the even tenor of their way, growing larger and larger. 'They were of many shapes, and probably of many habits. Some were certainly fish-eaters, and with their enormous jaws must have been most undesirable neighbours. Probably, however, they had plenty of diversity in their lives, and may have had many a bitter struggrgle with equally ferocious sea animals of other types. 'The scaly saurians, for example, were begiming to come on; and began in this era to assume the size and appearance that hare occasionally since been 


\section{THE CHALK PERIOD}

attributed to sea serpents. These reptiles, known as Dolichosaurs, were long-necked, lizard-like reptiles in the beginning of their career, and grew longer and longer in succeeding generations, till at last their descendants were so long and snaky that geologists have called the later specimens "serpents." These sea serpents were from fifteen to forty-five feet in length, and their remains have been found in the valley of the Meuse. They do not seem to have had a very long career, for they do not appear after the Chalk Age, and no direct descendants are known; but while they lived they ranged from North and South America to Europe and New Zealand.

The first true sea turtles appeared and lived and extended their families in great variety. They had broad flat forms, their shells only just covering their ribs like a short Eton jacket; but they were very large. The greatest of them, Archelon, had a skull larger than that of a horse, and must have measured fully twelve feet across the shell.

We may consider the birds at the same time as the sea animals or sea reptiles, since they, perhaps, were relations. Moreover, while the birds of Jurassic times were land birds, those of the Chalk period were aquatic. These birds belonged to two widely different classes, one consisting of large birds which did not fly, the other of small birds with great strength of wing and great powers of flight. Of the first kind was the Hesperomis. This was a large flightless bird, specially adapted to diving. Its wings hardly existed, for they had only one bone left; and that impiies the passage of a very long flight of time, 


\section{THE CHALK PERIOD}

during which the wings once in existence had become more and more useless, till they had dwindled to a mere nothing. But the Hesperornis had enormously strong legs, which were used as paddles, and their efliciency was increased by the bones of the foot being so joined to the leg as to turn edgewise in the water when brought forward. Any one who has ever paddled a Canadian canoe will appreciate the advantage of this. But this was not all, for the legs were so joined to the bodyframe as to stand out nearly at right angles (like a pair of oars), instead of standing under the body as walking legs do. Apparently walking as well as flying had been abandoned, and this bird had become a diver and swimmer merely. The head, neck, and body were long, and admirably shaped for plunging through the water. Favoured by the powerful hind limbs, the Hesperornis must have been very swift both on and under the water, and a formidable enemy to the fishes on which it preferred to feed. Its jaws were armed with teeth set in a groove, and, like the jaws of snakes, were separable so as to admit large prey. As these strange birds were sometimes six feet long, they must have been able to account for fish and reptiles of considerable size. They probably lived nearly altogether on and in the water.

The second type of bird, Ichthyornis, were small birds, scarcely larger than pigeons and a little like terns in appearance. They were splendid fliers, and were armed with teeth set in sockets. Their legs and feet were small and slender, but their wings very strongly devel- 


\section{THE CHALK PERIOD}

oped. They frequented the same seas and places as the Hesperornis, and yet the two were farther apart in structure than any two types of birds now living. Compared with the Archocopteryx, both these types of birds show progress in the shortening of the long, curiously feathered tail and the loss of the fingers and claws; but both retained the teeth of primitive birds. We may perhaps be allowed to depart from the strict adherence to geologic chronology by tracing here, instead of in the next chapter, the subsequent history of the early birds. In the strata of the next era remains of various birds were found. One of great interest, on account of its enormous size, was the Pharorachus of America. It was rather like, in type, a living bird known as the Cariama or Screamer. But if the extinct bird (of which the skull only has been found) had the general proportions and habits of the Cariama it must have been a terrible monster, standing some twelve feet high, and far exceeding the most powerful eagles and vultures in strength and the size of its beak and claws. Great extinct wingless birds are found in the quite recent "alluvial" deposits in New Zealand and Madagascar.

Something more than half a century ago a piece of bone was sent to Sir Richard Owen by a visitor to New Zealand who had just arrived there, and who had found it in his garden. Professor Owen, on examination, was able to say, from the general make and structure of the bone, that it was the bone of a bird. It was about seven or eight inches long. On examining the 


\section{THE CHALK PERIOD}

ridges and various marks on the bones, Owen was able to say that it was identical with the niddle of the thigh-bone of an ostrich. He ventured then to publish that this bone was a proof that there existed formerly in New Zealand a huge land bird like the ostrich, only bigger. After a few years more bones were sent to Owen from New Zealand, which entirely confirned what he said; and in the course of a few years he was able to put together from the bones sent a skeleton with enormous legs and neck-the skeleton of the ostrichlike bird the Moa of New Zealand. Since that time a great number of these birds have been found buried in the morasses and swamps of that country. The Moo is allied to the ostriches of Africa, the emus and cassowaries of Australia, and the rheas of South America.

The Moa of Madagascar was smaller, and is known as the Epyornis. But it lays the largest egg known, a tremendous thing as big as a Rugby football. It was this very large egg which inflamed the imagination of ancient navigators, and led to the vast exaggeration in describing the so-called "Roc," which Sindbad met with in the Arabian Nights. In concluding these brief notes on extinct birds we must also mention the present-day "kiwi" in New Zealand, which resembles in some respects the Apteryx, or most ancient of birds.

Let us now return to the land reptiles of the Chalk period. These are chiefly found in America, which was not submerged, as the greater part of Europe was, beneath the ocean. The incursion of the sea was more limited in the western hemisphere, and the land area was large 


\section{THE CHALK PERIOD}

enough to allow the continued progress of the land reptiles, though even here the sea reptiles seem to have done best. The great Dinosaurs still kept in the forefront, but they were not quite so pre-eminent as heretofore. The flesh-eating forms were less abundant, though among them an enormous kangaroo-like reptile, fifteen feet long, made its appearance. The Dryptosaurus must have been speedy, very powerful, and its habits must have made it appear like an ogre in seven-league boots to its smaller inoffensive neighbours. The Spoonbill Dinosaurs (Hadrosaumus) were very curious creatures, who also faintly resembled a kangaroo, but had enormous lower parts and crocodile-like tails.

But the most singular development appeared in the Ceratops family of the vegetarian reptiles, particularly in the genus called Triceratops. These were very large quadrupeds with enormous skulls which stretched back over the neck and shoulders in an enormous cape or hood of bone. Added to this was a sharp parrot-like beak, a stout horn on the nose, a pair of large pointed horns on the top of the head, and a row of projections round the edge of the cape. The Tricerutops wanted all the protection it could get, for it had no intelligence worth mentioning. Professor Marsh remarks that they had the largest heads and the smallest brains of the reptile race.

The heavy armour of the head of the Triceratops must have been developed for purposes of attack and defence, but we do not know whether it was for fighting their own species or for protection against the carnivorous 


\section{THE CHALK PERIOD.}

reptiles. "So long," says Professor F. A. Lucas, "as Triceratops faced an adversary he must have been practically invulnerable, but, as he was the largest animal of his time, it is probable that his combats were mainly with those of his own kind, and the subject of dispute some fair female upon whom rival suitors had cast covetous eyes. What a sight it would have been to have seen two of these big brutes in mortal combat, as they charged upon each other with all the impetus to be derived from ten tons of infuriate flesh! We may picture to ourselves horn clashing upon horn, or glancing from each bony shield until some skilful stroke or unlucky slip placed one combatant at the mercy of his adversary. . . .

"A pair of Triceratop's horns in the National Museum (at Washington) bear's witness to such encounters, for one is broken midway between tip and base; and that it was broken during life is evident from the fact that the stump is healed and rounded over, while the size of the horns shows that their owner reached a ripe old age."

In connection with the concluding part of the last sentence it should be mentioned that reptiles, like fishes, but unlike birds and mammals, continue to grow throughout their entire span of life, so that unusually large bodily size is, at all events as a rule, an indication of advanced age. As regards general appearance Triceratops may, perhaps, be best described as a reptilian rhinoceros, with the proviso that the tail was much larger and thicker than in that group of animals, and passed insensibly into the body, as in reptiles generally, while the number and arrangement of the horns were different. 


\section{THE CHALK PERIOD}

The Pterosaurs, or flying reptiles, made, as we have said elsewhere, a great advance. Williston regards them as having come to excel all other flying vertebrate animals. Some attained a wing-spread of twenty feet, and they could fly far and fast. They were all shorttailed; some of them probably could scarcely walk, and the larger of them had no teeth. Their bills resembled those of modern birds, and they have been styled the kingfishers of the Cretaceous seas. Terrific to look upon, they were probably not very deadly animals except to small fishes. The lizards did not make much progress; but the snakes made their first appearance, though they remained small; and the mammals showed little progress from the forms which were found in the previous era of the Jurassic.

At the close of the geological period whose natural physiognomy we have thus traced, Europe was still far from displaying the configuration which it now presents. A map of the period would represent the great basin of Paris (with the exception of a zone of Chalk), the whole of Switzerland, the greater part of Spain and Italy, the whole of Belgium, Holland, Prussia, Hungary, Wallachia, and Northern Russia as one vast sheet of water. A band of Jurassic rocks still connected France and England at Cherbourg-which disappeared at a later period, and caused the separation of the British Islands from what is now France. 


\section{CHAPTER XXII}

\section{THE AGE OF MAMMALS}

THE Geological Record is not perfect. There are breaks in it such as have not and may never be filled up; and it is because of these breaks that some of the divisions are made in geologic time. At present the earth's crust has only been scratched for fossils. Great parts of Asia and of Africa and of South America remain to be explored, and they may in some future generation fill the gaps of our knowledge and render superfluous some of the divisions which geologists now place in the eras of the rocks and of the fossils. But so far as we know at present there were real breaks in the history of the continents, perhaps not swift or sudden, but wholly changing the appearance and the life, vegetable and animal, of half a world, perhaps the whole world at a time. Many geologists believe that the secret of these changes lies in the core of the earth; and that, to use our old simile of the golf ball, when the tension and pressures inside the earth grow too much for its strength something gives way, and the whole world begins to change, the continents sinking under the oceans 


\section{THE AGE OF MAMMALS}

and new lands arising. We shall not again consider this idea in all its bearings, or ask whether there is any simpler explanation to be found in the never-ceasing explosive tremors of the crust; but we shall only say that the last of these great changes set in at the end of the Chalk age. After that era we arrive at the period among the rocks which, with all its subdivisions, Eocene, Miocene, Pliocene, Quaternary, is classed as Cainozoic or Modern.

Let us sum up the changes broadly. The Tertiary period, which now begins, has been called the Age of Lakes: but this merely means that there were great lake deposits, and it is true to say that as contrasted with a period of great waters, the Tertiary is to be considered as the period of land. That does not mean that there were in all the hundreds of thousands of years which it embraces no advances and retreats of the sea, no submergings and uprisings of the land. There certainly were. But the land was dominant, and it is the land animals and the land vegetation that are the most important and progress most. After the earth movements which occurred at the end of the Mesozoic or Secondary period there appears to have followed a period of quiet. There was a considerable area of land standing high above the waters; and there began one of the minor but considerable encroachments of the sea in North America. It is probable that the Pacific and the Atlantic joined between North and South America. At the end of this first period the sea withdrew again, and what is called the Miocene period began with a lowering of the temperature of the waters 


\section{THE AGE OF MAMMALS}

of the Atlantic; and lastly followed the great extension of the land towards the north, the great withdrawal of the sea of Pliocene times, and the growing cold which led to the glacial era of the Pleistocene period. In Europe and in Asia we may note that the great areas which are now covered by the Alps and the Himalayas were at the beginning of the Tertiary period still under water and only a few signs (in the form of islands) of these mighty ranges were beginning to appear.

Pre-eminently the age which comprises all these periods is the Age of Mammals. But one of the changes which European geologists first noticed was the surprising change which took place in the marine fossils. The animals of the sea which were familiar during the Chalk period nearly all disappeared and were replaced by new ones. The great saurian reptiles, from the monsters of the land to the mososaurus serpents of the sea, disappeared, and most other reptiles showed profound changes, showing a revolution in the animals of the land corresponding to that of the sea. Lastly, in this first period, the Eocene, mammals suddenly appear in force and occupy the first place among the animals. The vegetation did not change so much as might have been expected.

Whence came the mammals? 'That, again, is one of the questions which time alone can completely answer. But the opinion of most geologists is that they arose and developed in Asia first of all, and then sprend to other continents. The rise of the mammals, which, 


\section{THE AGE OF MAMMALS}

unlike the reptiles, bring forth their young relatively mature and nourish and protect them, was contributing to the downfall of the reptiles, though it cannot be considered an actual cause. 'The mammals' young had a better chance of living and surviving than had the eggs of reptiles. Moreover, the mammals began with superior agility and higher brain-power. It is not surprising, therefore, that the invasion of the mammals resulted in the clumsy, affectionless, small-brained reptiles being driven either into extinction, or into the sedges and rushes, the swamps and lagoons, the coverts of the jungles, the crevices of the rocks, and the various byways which the mammals cared least to frequent, and that they have been kept there to this day.

At first the mammals were not very different in habit or type from one another. Small animals, which, like the shrews, moles, and hedgehogs lived on insects were among the earliest. There were others whose toes were turning to hoofs in order to fit them for fleetness; and there were some curious creatures called Coryphodons, which were like the modern tapir, though they were tusked like boars. The Coryphodon was a slow beast, with toes like those of an elephant, though it was much smaller.

In America appeared a small animal not much bigger than a fox-terrier, which was the ancestor of the horse, and of which we shall have more to say. The birds increased, and forms like those of the heron mingled in the swamps with other goose-like birds that kept in their serrated bills some traces of the teeth of their early 


\section{THE AGE OF MAMMALS}

ancestors. Others, like kingfishers, flitted over the streams; and the emu, ostrich, and moa, as well as the albatross, find their earliest representatives in the Eocene times.

It is impossible for us to follow, or even to enumerate, all the varied ancestral lines which sprang up, some of them already vigorous, in the early Tertiary times, and which developed so mightily in the successive ages. We can only trace the careers of a few such as are better and more popularly known, while admitting that there are many others equally interesting from a scientific or from any other point of view. From a geologist's point of view the most important, perhaps, of all the mammal developments was that of the elephant. The first mammal which geologists discovered that was like the elephant was the Mastodon, the American variety of which is called Tetrabclodon. But this Mastodon had no proper trunk as has the elephant. Instend of that he had a very long upper lip which apparently rested on his projecting upper tusks. Mr. Kipling once suggested that the elephant's trunk was originally formed by an accident -an unfortunate young elephant before the days of trunks having stopped to drink at a pool, and his nose being seized by a crocodile, who pulled and pulled till the nose lengthened out a trunk. There certainly was some reason for the elephant's trunk, which has developed, we do not quite know how, from a long nose. But a great deal has been found out about the carly derelopment of the elephant by Dr. Andrews of the British Museum. 


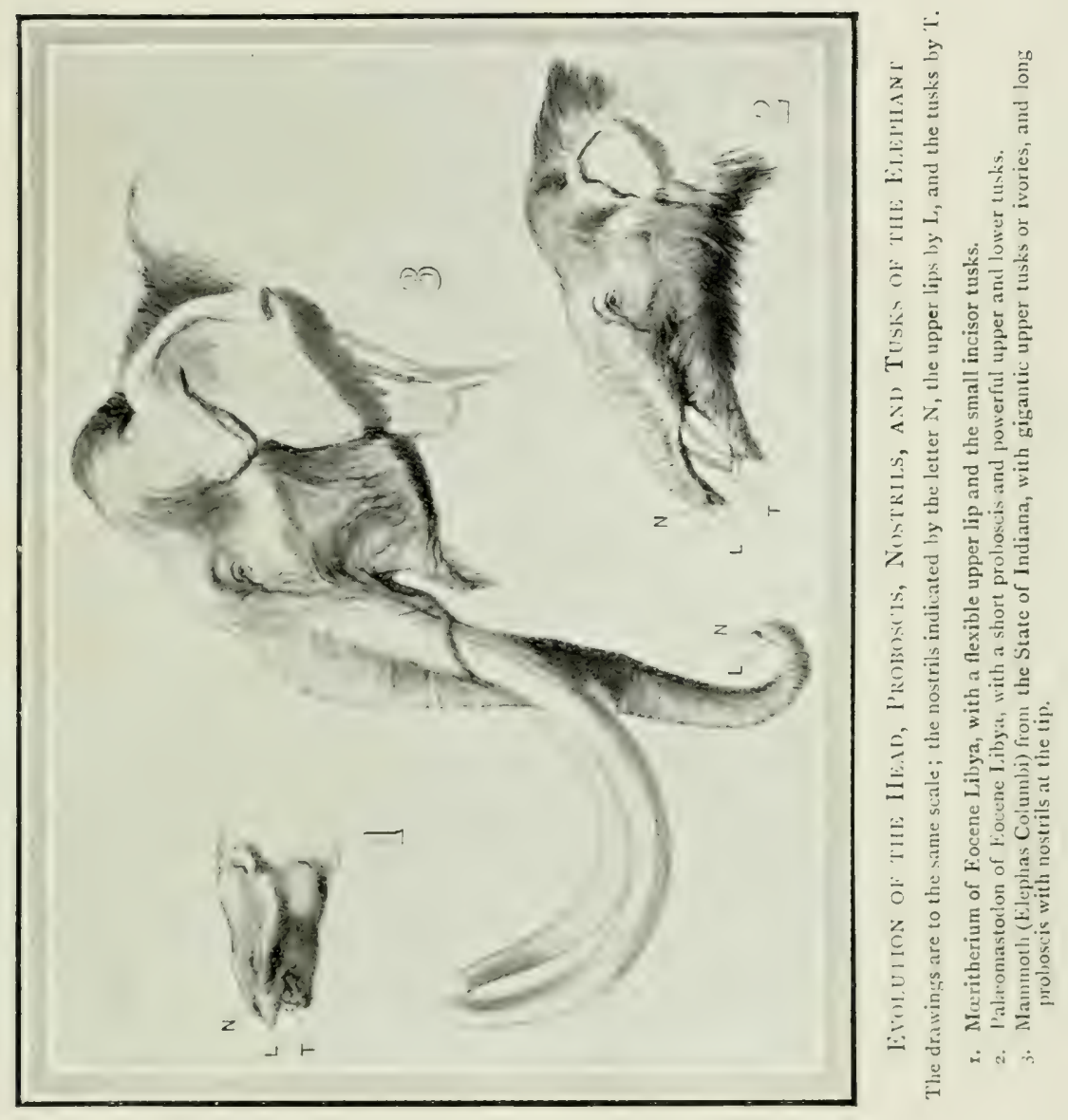





\section{THE AGE OF MAMMALS}

Dr. Andrews was travelling in Egypt some years ago, and joined a party of officers of the great survey of Egypt in a visit to the Great Western Desert, the rainless, sandy waste west of the Nile, not very far from what is now called the Fayoum, and where in Roman days was the great Lake Mœris, now dried up to a mere brine pool, in the salt water of which the fresh-water fishes of the Nile still live. The surveying party intended to determine the geological age of these sands, which stretch for hundreds of miles, often rising into cliffs which are cut sharp by the wind and show horizontal stratification. The geologists determined that the sands of this region were of Eocene and Miocene Age, and from them Dr. Andrews brought home some very interesting bones. These included the remains of a more primitive Mastodon than any as yet known, and of an animal which he called Meritherium, which is a connecting link between elephants and other mammals. The collection included also remains of great flesh-eating beasts, and of sea cows, of tortoises, and of a snake sixty feet long!

However, in regard to the history of elephants, the upshot of Dr. Andrews' most important discoveries is that we find living here in the Upper Eocene period (which is older than the age in which the Tetrabelodon Irastodon was found) an elephant ancestor of the kind to which Dr. Andrews gave the name of Palacomastodon or "ancient mastodon." We thus arrive at an ancestral elephant-like creature which serves to join the elephant stock on to more ordinary mammals. This beast was not 


\section{THE AGE OF MAMMALS}

so very big, perhaps about the same size as an ordinary cart-horse.

Dr. Andrews' further triumph was the additional discovery of the rather smaller animal which he called the Meritherium, and which was undoubtedly an elephant of sorts, though at first sight it has no resemblance to one, and probably had no trunk at all. It certainly had no big tusks; but its teeth make us certain that it belonged to the elephant family. "Here, then," says Sir E. Ray Lankester, "we have arrived at a form which undoubtedly was closely related to the ancestors of all the elephants, if not actually itself that ancestor, and in it we see the origin of the elephant's peculiar structure. From this comparatively normal pig-like Meritherium, the wonderful elephant, with his upright face, his dependent trunk, and his huge spreading tusks has been gradually, step by step, produced. And we have seen some, at least, of the intermediate steps-the lengthening of the jaws and the increase in the size of the teeth in the Palceomastodon-carried still further on by the Tetrabelodon, and then followed by a shrinkage of the lower jaw and final evolution of the middle part of the face and upper jaw into the drooping, wonderful, prehensile trunk."

The long-chimned elephant requires, howerer, a few moments' consideration from an altogether different point of view. This species appears to have had the widest geographical distribution of any member of the family, of which it may be regarded as the great colonising or emigrant representative. First developed in North 


\section{THE AGE OF MAMMALS}

Africa, where its remains occur in the early Miocene strata of Mogara and Tunisia, this species ranged right across Europe to the confines of North-Western India, having probably reached Italy from Africa by means of a landbridge by way of Sicily, and thence travelling through Greece into Asia. On the latter continent it appears to have given rise to the modern elephants, as remains of the former are unknown in any other part of the world.

If this be true, it follows that elephants of the modern type subsequently migrated into Europe and thence to Africa, while in the other direction they wandered by way of Behring Strait to America. Hence we are led to the remarkable conclusion that while the first elephants appeared in Africa, the modern African elephant is of Asiatic parentage, and a comparatively recent immigrant into the land of its forefathers. Next to man and the carnivora, elephants appear to have been the greatest travellers the world has ever produced, for, starting from their North African birthplace, they reached by the Behring Strait route nearly to the extremity of South America, while to the north they penetrated the Arctic circle, and to the south, on their return journey, reached the coast in the neighbourhood of Cape Town.

Another great traveller was the horse. The first undoubted horse-like animal was Eohippus, a little creature about eleven inches in height at the shoulder, and in general rather more like the flesh-eaters than the horses of the present day. The back was arched, the head and 


\section{THE AGE OF MAMMALS}

neck were short, and the limbs of moderate length, showing no remarkable adaptation for speed. This genus had a remarkable range, having apparently originated in England (then a part of Western Europe), and migrated by way of Europe and Asia, and what is now Behring Strait, to America, where it got as far east as New Mexico. This migration of Eohippus shifted the scene of evolution to the western hemisphere, for while examples of it are continually and continuously found there in succeeding strata it only appears occasionally in Europe, as if the remains there had been those of mere emigrants.

Later on the horse developed in America, growing larger till it was first as big as a collie-dog, with signs of being more adapted for speed. It then had four toes on its foot. It continued, though very gradually, to grow larger, and even more gradually its unnecessary toes grew fewer and fewer till at last they disappeared.

At length appeared the horse which had only one toe. This type, that of the modern horse, first becomes known in the Upper Pliocene beds of Europe, and represents the culmination of the race. The completeness of the record of the evolution of the horse tells us something of the enormous numbers of ancestral forms which must have existed in the more than two million years that have elapsed since the first diminutive horse appeared in North America. While not strongly given to migration, in the course of time these animals wandered over the entire world, with the exception of such inaccessible 


\section{THE AGE OF MAMMALS}

places as Australia and the Oceanic Islands. . . I It would seem that the original stock was of Eurasian derivation, though the great theatre of the evolutionary drama was soon transferred to North America, the Eurasian, African, and South American horses which appear from time to time being in all probability of North American origin. 'The ultimate fate of the horses in both North and South America was extinction, all wild horses of our own time, including the asses and zebras, being confined to Asia and Africa. The apparently wild bands of the American western plains, and those which roam over the pampas of South America, are the descendants of domestic horses that have escaped from human bondage, largely from the early Spanish explorers.

The rhinoceroses of to-day, the one-horned Indian variety and the two-horned African rhinoceros, were preceded by a whole regiment of rhinoceroses in the 'Tertiary period. One such was dug out in Fleet Street during the excavation for the Daily Chronicle office. This rhinoceros had a hairy coat like the Mammoth which lived much later, and in Siberia is found sometimes side by side with the later quadruped. Many of the extinct rhinoceroses had two horns like the African square-mouthed rhinoceros, which is sometimes misleadingly called the white rhinoceros. One great extinct beast, the Elasmotherium, allied to them, had a great horn carried on a huge boss in the middle of its head instead of on the nose, while another still huger animal called the Titanotherium and found in North America had a pair of horns perched on either 


\section{THE AGE OF MAMMALS}

side of its nose. As large as the rhinoceros but having a very different arrangement of the bones of its ankles and wrists and very different teeth and horns are the extraordinary creatures known as Dinoceras, whole skeletons of which have been disinterred from the Eocene strata of Wyoming in the United States by Professor Marsh. These creatures had three pairs of horns on the top of the head and a pair of great tusks as well. Nearly all these animals, though they were more brainy than the reptiles, had much smaller brains in proportion to their size than the bulk of the animals which now roam the earth, from which we may surmise that though a small brain suffices to guide a great animal machine in established ways, yet in order to learn new things in its lifetime an animal must have a big brain.

The last great mammal we must mention in this series is the Arsinoitherium, which was found only a few years ago by Dr. Andrews in Egypt, in the same strata whence he obtained the fossil ancestors of the elephant. It was so called because it was found near the palace of Arsinoë, the name of the Egyptian queen of Greek race. But Arsinoitherium was far from being a graceful ladylike creature, and, resembling in general appearance a rhinoceros, had two enormous bones, which grew out of its nose on either side of it. The bones were hollow and were probably covered with skin in life; and Arsinoitherium had a wonderful and wonderfully even set of teeth. To conclude, we must add a representative mammal of this period, the Sivatherium, found in India, and the Samotherium, found in the Isle of Samos, which were like 


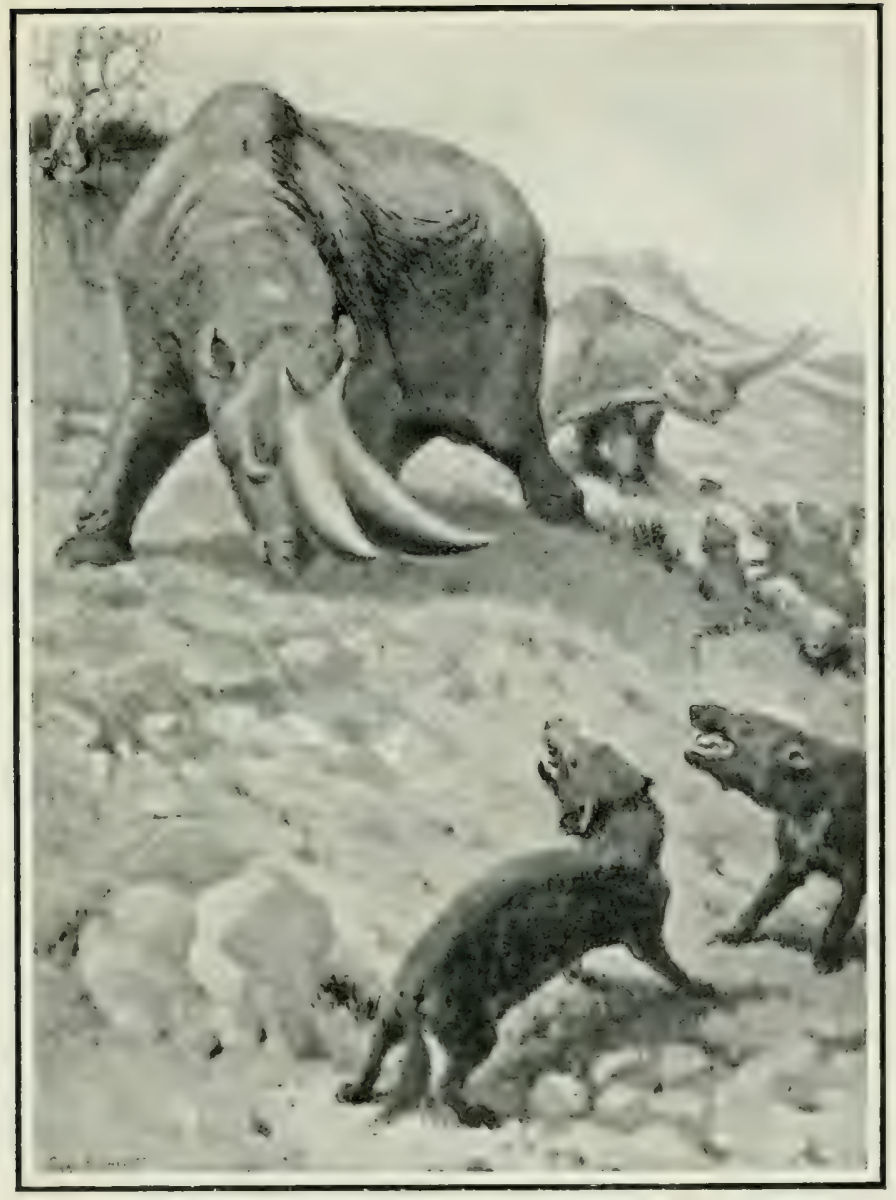

TWO ARSINOITHERUMS (PREHISTORTC RHINOCEROS) AT BAY BEFORE A PACK OF HYEXODONS

The Arsinvitherium stood 5 feet $g$ inches at the withers, and measured $g$ feet $g$ inches from snout to rump. The hyarnodons (hyana touthed) were no relation of the modern hy:ena. They had bodies like the Tasmanian wolf, and were wonderfully adapted to capture both land and water living prey.

(Drawn under the direction of Prof. Osborn.) 



\section{THE AGE OF MAMMALS}

giraffes, and the beginning of the sloth-like animals, whose appearance we must, however, deal with in another chapter.

The whales whose remains are found in the Pliocene rocks differ little from those now living; but the observations geologists have been able to make upon these gigantic remains of the ancient world are too few to allow of any very precise conclusion. It is certain, however, that the fossil differs from the existing whale in certain characteristics perceptible in the bones of the skull. The discovery of an enormous fragment of a fossil whale, made at Paris in 1779 , in the cellar of a wine merchant in the Rue Dauphine, created a great sensation. Science pronounced, without much hesitation, on the true origin of these remains; but the public had some difficulty in comprehending the existence of a whale in the Rue Dauphine. It was in digging some holes in his cellars that the wine merchant made this interesting discovery. His workmen found, under the pick, an enormous piece of bone buried in a yellow clay. Its complete extraction caused him a great deal of labour, and presented many difficulties. Little interested in making further discoveries, our wine merchant contented himself with raising, with the help of a chisel, a portion of the monstrous bone. The piece thus detached weighed 227 lbs. It was exhibited in the wine-shop, where large numbers of the curious went to see it. Lamanon, a naturalist of that day, who examined it, conjectured that the bone belonged to the head of a whale. As to the bone itself, it was purchased for the 'T'eyler Museum, at Haarlem. 


\section{THE AGE OF MAMMALS}

Lastly, we must not omit to mention that in the Old World the first true apes, Oreopithecus and Dryopithecus, appeared. The first of these united some of the characteristics of apes and monkeys; the second, about the same size, was more closely related to the chimpanzee and gorilla. 


\section{CHAPTER XXIII}

\section{THE ICE AGE}

COR some reason or reasons concerning which there has been a great deal of speculation but not a large amount of agreement, the closing stages of the last geologic era which precedes our own and which links the great past to the present, were distinguished by great cold and by widespread fields of ice. Ice-sheets spread over six or eight million square miles of the earth's surface where not long before mild climates had prevailed. Were it not for this great Ice Age and for its far-reaching effects on the conditions under which Man has developed, this period, which is sometimes called the Pleistocene, (from Greek words meaning the "most recent"), would be more properly joined to the era which we have just been discussing, the two periods constituting a single period of great land elevation and of ocean-shrinking. This period, however, is now thought to be much more important than it was formerly, and perhaps longer in duration.

More than half the ice-covered land lay in North America and more than half the rest in Europe. The glaciation, therefore, was probably confined to certain parts of the world and did not stretch all over the planet. 


\section{THE ICE AGE}

But the whole world felt its effects; even in tropical regions ice and glaciers occurred on mountains where they did not exist before and do not exist now, and on mountains which now have glaciers the ice descended to levels 5000 feet below the point where it now stops. The southern hemisphere was affected as well as the northern, but to a much less degree. In Patagonia and New Zcaland glaciers rept down from the mountains and spread out on the plains. Glaciers formed on the mountainous tracts of Tasmania and Australia where none exist now. Most of the higher mountains of the southern hemisphere bore glaciers. The Antarctic regions were presumably buried beneath ice and snow as they are at present, but of that we are not certain.

In Asia ice-ficlds far greater than those existing to-day affected the higher mountains, and from the Lebanon to the Caucasus and from the Himalayas to Siberia and China traces of glaciers are found where they are not to be seen now. Yet on the plateaux and lowlands of Asia ice-sheets were far less extensive than in Europe and in North America.

In Europe there were large glaciers in the southern mountains and extensive ice-sheets on the southern plains. Radiating from the Scamdinavian highlands a succession of great ice-shcets crept forth on the lowlands of Russia, Germany, Demmark, IIolland, and Belgium, and crossing the shallow basin of the North sea touched the shores of Great Britain, where they were met by ice radiating from the mountains of these isles.

From the Alps gigantic glaciers descended to the low270 


\section{THE ICE AGE}

lands in all directions. Then the Rhine glacier moved out far beyond the mountains and joined with the glaciers of Savoy and Dauphiny on the plains of France, while from the Southern Alps glaciers invaded the fertile plains of Italy.

Glaciers of similar size and extent descended into the valleys of the Rhine and Danube. The Pyrenees, some of the higher mountains of the Spanish plateau, the higher mountains of France, the Apennines, the Carpathians, the Balkans, the Urals, all had their ice-sheets. Iceland and the Faroe Islands were buried under ice, and even Corsica had snowfields and glaciers, some of which were not small.

Nearly one half of North America was buried in ice. Strangely enough, it was not the whole northern half, but the north-eastern half that was specially ice-invaded, and, more strangely still, not so much the mountainous portions, though these were affected, as the plains. Alaska was largely free from ice except on or about the mountains: and there was less ice on the western plains than in the valley of the Mississippi. Much the greater part of the four million square miles of ice-field lay on the plains of Canada and in the upper Mississippi valley. The Missouri and Ohio rivers like two great arms embraced the borders of the ice-fields to which they owe their origin.

We do not propose to examine the several theories which have been proposed to account for this extraordinary cold, for none is completely acceptable or accepted, but we may just mention them. Dr. Croll a 


\section{THE ICE AGE}

century ago suggested that the cold may have been due to the alterations in the shape of the earth's orbit, alterations which astronomers tell us take place regularly, though very slowly and at intervals of millions of years. If so, this glacial period was only the last of many glacial periods; the traces of the earlier ones having, however, been for the most part obliterated and destroyed.

Sir Charles Lyell has urged that geographical changes (elevations and subsidences) would of themselves be sufficient to bring about a glacial period, which (he says) would be the result of a great continent being formed round the North Pole while oceanic conditions prevailed at the Equator. Another theory is that the heat given out by the sun is not always equal, being sometimes more (when even polar countries enjoy a warm climate) and sometimes less (when only the equatorial regions are habitable). The objection to this theory is, of course, that we have no proof that our sun is of greatly variable heat. Whatever may have been the cause of the glacial period, we know as a proved fact that a long time ago (as measured by years, although the event itself is among the latest of the many changes recorded in the geological history of the earth) the climate of the British Isles was so intensely cold that the greater part of this country was covered with ice and snow, and we know also that this intense cold was sufficient to change in many respects the habits and appearance of the animals and regetation of the earth. How much this was the case can be gathered from the fact that in the 


\section{THE ICE AGE}

period which preceded it animals which now live in the tropics roamed in the Arctic circle, and figs and magnolias grew in Greenland.

The last word we shall have to say on the climatic conditions of this period is that the Ice Age had its sub-periods and divisions like all other epochs and in them the ice sometimes retreated, and consequently in parts of the earth where there had been snow and ice, and where there were to be ice and snow again, the wintry conditions retreated (for centuries, perhaps, at a time), and the valleys and plains basked during these intervals in sun and rain and warmth. These epochs are called "inter-glacial epochs."

The life of the regions not much affected by the rigours of snow and ice is gradually being ascertained by geologists now. One of its most marked features was the retreat of the northern and Asiatic animals before the advancing ice towards the warmer tropics and Equator; these animals journeyed back northward again whenever the retreating ice would let them. The great Proboscideans, the Mastodon and the Mammoth were members of this group, and so were the bear, the bison, the musk ox. With these mingled towards the south several types (which were gradually becoming extinct in North America) such as the horse, tapir, llama, and the sabre-tooth cat. A second prominent feature was a southern group in the western hemisphere, consisting of gigantic sloths, armadillos, and water-hogs; and now for the first time the interest of animal life shifts to South America. 


\section{THE ICE AGE}

"There are many instances," says Sir Edward Ray Lankester in his book on Eatinct Animals, " in which small living animals were represented in the past by gigantic forms very close in structure to the little living beasts, but of much greater size. Hence it is concluded that these particular living animals are the reduced and dwindled representatives of a race of primeval monsters. There is some truth in this, as may be seen from the history of the living sloths and armadillos of South America, as compared with the extinct gigantic sloths and armadillos dug up in that country. But it is a great mistake to conclude from this that it is a law of nature that recent animals are all small and insignificant as compared with their representatives in the past. That is simply not true. Recent horses are bigger than extinct ones; recent elephants are much bigger than their earlier elephantine ancestors. There never has been any creature of any kind-mammal, reptile, bird, or fish-in any geologieal period we know of, so big as some of the existing whales, the Sperm Whale, the great Rorqual, and the whalebone whales.

"It is true that there were enormous reptiles in the past, far larger than any living crocodiles, standing fourteen feet at the loins, and measuring eighty feet from the tip of the snout to the end of the tail; but their bodies did not weigh much more than a big African elephant, and were small compared with whales. So let us be under no illusions as to extinct monsters, and proceed to look at those of South America with simple courage and confidence in our own day." 


\section{THE ICE AGE}

The peculiar productions of South America in the way of animals appear to be the members of the group of mammals called Edentata found nowhere else. When, however, South America, which once was an island, joined on to North America, numbers of animals, mastodons, horses, tigers, and tapirs, emigrated from north to south, and perhaps proved too much for the aboriginal or native beasts. At any rate, all the big South American mammals died out, and now there are left only the small tree sloths, the small armadillos, and the strange-looking ant-eaters. But in quite late geological deposits of South America we find the bones of gigantic armadillos and of gigantic ground sloths, which lasted on till the time when man appeared on the scene.

The Glyptodon, of which there were several different kinds, was an enormous armadillo as big as an ox. Like their small, puny, modern descendants, they carried on their backs a hard case of bones, something like the shell of a tortoise. The modern armadillo's shell, however, is jointed so that the little animal can roll itself up into a ball, and in this direction, therefore, the armadillo, though it has decreased so much in size, has advanced in adaptability.

The Megatherium was nearly as big as an elephant, and its skeleton, though so much larger, is very similar to those of the small sloths of present-day South America. Its teeth also are very much like theirs. But whereas the living sloths climb trees, as they have learnt to do, the Megatherum's method was more primitive though 


\section{THE ICE AGE}

quite as effective. It stood on the ground and pulled the trees down in order to eat the young branches. 'The Mylodon, which lived at the same time, was not so big, and its habits were similar. It had a number of little bony pieces scattered in its skin in the region of the back, like the pieces forming the bony case of the ancient armadillos; but the pieces in this case were not closely fitted together.

It was supposed that the Mylodon, like all the peculiar gigantic animals of South America, had become extinct as long ago as the Mammoth (of which we shall say more presently) or of the woolly rhinoceros which used to haunt Fleet Street. All these extinct South American animals were distinguished by peculiarly shaped teeth, and had no teeth at all in front. They are called, therefore, Edentata, and their representatives to-day are much smaller.

But some years ago Dr. Nordenskjold, a Scandinarian traveller, while exploring in Patagonia, found a rast carern called the Ultima Speransa cave, on the westem coast. From this cavern the settlers who lived close by had removed an enormous piece of skin covered with greenishbrown hair, and studded on its inner side with little knobs of bone. The skin was dry but sound. When it was placed in water it gave out a smell which, though unpleasant, was very interesting, for it showed that the animal which had worn it could not have been dead thousands or even many hundreds of years. It was, in fact, evidently a piece of the skin of a Mylodun, which had survived in this region until modern times. 


\section{THE ICE AGE}

Further explorations were made in the cavern by Dr. Moreno, of La Plata, and other naturalists, and an immense quantity of bones was obtained, and more portions of the skin of Mylodon with the hair on. The cavern had been inhabited probably several centuries ago by Indians, for human bones and weapons were obtained.

The remains of as many as twenty Mylodons have been obtained from the cavern, and many of the bones are cut or broken in a way which leads us to suspect that the human inhabitants of the cave cut up the dead Mylodons for food, and split their bones to obtain the marrow!

Some of the Mylodon bones, skulls, jaw-bones, legbones, etc, are smeared with blood and have pieces of cartilage and tendon attached. There are other evidences which go to show that the Indians may have kept the Mylodons alive in the cave and fed them with hay brought from the outside. Anybody who would care to see the last of the great extinct animals can inspect some of these remains at the museum in Cromwell Road, London.

Besides the relics of the Mylodon and of Man the cavern has yielded bones and teeth, and many horny hoofs belonging to a kind of extinct horses ; and this constitutes one of the puzzling things about this cave treasure. The cave is in a part of the country very difficult to reach, and though Sir 'Thomas Holdich and Mr. Hesketh Prichard made efforts to reach it again and explore it systematically and scientifically, there is 


\section{THE ICE AGE}

a great deal about it that seems likely to remain unexplained.

The bones that were found are not buried in lime or any preserving stone; but lie in sand where one would expect them to have perished long ago if they had been of any great age. Yet side by side with them are the bones of a long-extinct horse; and there is no tradition among the Indians to-day of any huge beast corresponding to the Mylodon. Sir E. Ray Lankester has pointed out that the whole of South America has been submerged and has risen (and is rising still) for many centuries. Possibly the rocks and high lands where the Mylodon cavern occur's formed an island during the submergence, where a number of early animals took refuge and survived until the re-elevation of the landand so lived on in the present condition of the land sur. face until fifty or a hundred years ago. The great land tortoises (like the Galapagan" tortoise) have similarly survived on a few equatorial islands. Possibly, though it does not seem very likely, the Mylodon is still living in similar caverns in this region, as yet unvisited by man.

In Australia, the land of the marsupials or mammals with pouches, the bones of many gigantic creatures belonging to that tribe of animal hare been found. Giant kangaroos, twice as tall as the biggest living kangaroo, wombats and voles as big as a rhinoceros, have been discovered. One of these is the Diprotodon, which Sir

* Of the Galapagos Islands: 


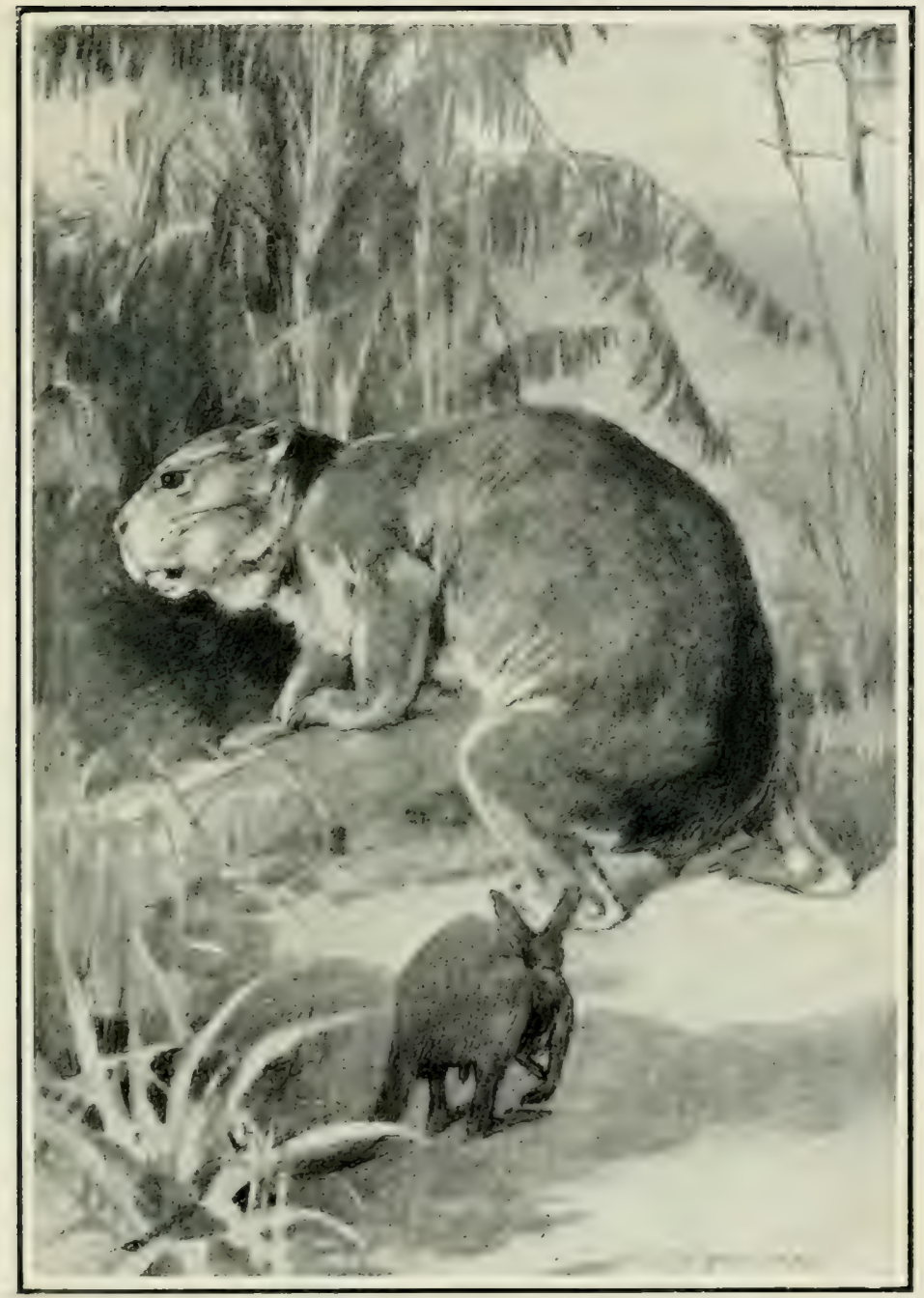

DIIROTOUON

Equal in size to a large rhinoceros. (Remains fund in Australia.) 



\section{THE ICE AGE}

Richard Owen reconstructed much in the same way that he reconstructed the $1 I 0 a$, and of which Dr. Stirling has since found complete specimens in a morass in South Australia.

Last of all of the great extinct mammals which we shall mention is the Mammoth, which has a peculiar interest because, like the Mylodon, it certainly survived until man was on the earth, as there are many more evidences to prove.

In one of the caves of France inhabited by prehistoric men and thickly strewn with the chipped flints which they used as tools and weapons, as well as with the bones of extinct animals which they ate, a piece of Mammoth's tusk has been found on which is rudely but cleverly carred, evidently by the men who lived there, the picture of a Mammoth. (There are besides, antlers on which a reindeer is very cleverly and artistically outlined. Even the tuft of hair below the chin is shown, and the great feet and the extra toes are correctly pictured. Clearly the men who drew this reindeer lived with the reindeer; and besides the reindeer, living near these men in the south of France, was the great Mammoth.)

'The Mammoth was like an Indian elephant, but with a coarse hairy pelt. It was rather bigger than the big Indian elephant, and its tusks had a different curvature; but we may dispose of the popular idea that it was bigger than any elephant. No Siberian Mammoth has yet been found higher at the shoulders than nine feet six inches, whereas the African elephant stands eleven 


\section{THE ICE AGE}

feet and sometimes more at the shoulders. Among the fossil elephants of Southern Europe and of North America (Elephus imperator) there are two which stood from twelve to thirteen feet high. The remains of the Mammoth are left all over the north of Europe and Asia and of the countries which were subjected to glacial influences. Even in England its teeth and tusks are constantly found, and in the Natural History Museum there is a whole skull with enormous tusks, which was dug up in a brickfield at Ilford. Probably this animal continued to exist longer in Asia and Siberia than in our own part of the world: and the cold and ice preserved their remains so well that whole carcases have been dug up.

One such instance is historic. In 1799 a native chief near Lake Onkoul, in Siberia, while secking for Mammoth teeth, perceived a great shapeless mass among the ice. He watched it for some years, till at the end of the fifth year the ice melted and disclosed the carcase of a whole Mammoth.

In the month of March, 1804, Schumakhoff cut off the horns (the tusks), which he exchanged with the merchant Bultunof for goods of the value of fifty roubles (not quite eight pounds sterling). It was not till two years after this that Mr. Adims, of the St. Petersburg Academy, who was travelling with Count Golovkin, sent by the Czar of Russia on an embassy to China, having been told at Yakutsk of the discovery of an animal of extraordinary magnitude on the shores of the Frozen Ocean, near the mouth of the River Lena, 


\section{THE ICE AGE}

betook himself to the place. He found the Mammoth still in the same place, but very much mutilated. The Yakuts of the neighbourhood had cut off the flesh, with which they fed their dogs; wild beasts, such as white bears, wolves, wolverenes, and foxes, had also fed upon it, and traces of their footsteps were seen around. The skeleton, almost entirely cleared of its flesh, remained whole, with the exception of one foreleg. The spine of the back, one scapula, the pelvis, and the other three limbs were still held together by the ligaments and by parts of the skin; the other scapula was found not far off. The head was covered with a dry skin; one of the ears was furnished with a tuft of hairs; the balls of the eyes were still distinguishable; the brain still occupied the cranium, but seemed dried up; the point of the lower lip had been gnawed and the upper lip had been destroyed so as to expose the teeth; the neck was furnished with a long flowing mane; the skin, of a darkgrey colour, covered with black hairs and a reddish wool, was so heavy that ten persons found great difficulty in transporting it to the shore.

There was collected, according to Mr. Adams, more than thirty-six pounds weight of hair and wool which the white bears had trod into the ground while devouring the flesh. This Mammoth was a male, so fat and well fed, according to the assertion of the Tungusian chicf, that its belly hung down below the joints of its knees. Its tusks were nine feet six inches in length, measured along the curve, and its head without the tusks weighei four hundred and fourteen pounds 


\section{THE ICE AGE}

avoirdupois. Mr. Adams took every care to collect all that remained of this unique specimen of an ancient creation, and forwarded the parts to St. Petersburg, a distance of 11,000 versts (7330 miles). He succeeded in repurchasing what he believed to be the tusks at Yakutsk, and the Emperor of Russia, who became the owner of this precious relic, paid him 8000 roubles.

The skeleton is deposited in the museum of the Academy of St. Petersburg, and the skin still remains attached to the head and the feet.

A very curious example of the Siberian Mammoth was discorered only a few years agro by a Lamut of one of the Arctic villages, and through the energy of Dr. Herz was eventually removed in pieces to St. Petersburg. In the Zoological Museum there the reconstructed Mammoth now crawls out of a huge pit, for it was by filling into a pit that this fine beast met his death hundreds of generations ago. It was sunk in frozen ground, and this cold-storage treatment had preserved it in an extraordinary manner. If the Siberian natives who discovered it partially buried in alluvial deposit had not uncovered it, so that the sun was able to play on the carcase and produced decay, this wonderful primeval monster might almost have been got out whole. As it was the frozen ground had so kept the remains that Dr. Herz found well-preserved framents of food between the teeth, and the remains of a hearty meal in the stomach. 'There is no doubt that the Mammoth fell into the crevice or pit and damaged himself so much 


\section{THE ICE AGE}

in the fall that he could not crawl out. One cannot help feeling some relief that he died after a short deathstruggle. A good deal of the very old meat of this body was eagerly eaten by the native dogs. 


\section{CHAPTER XXIV}

\section{THE KINGDOM OF MAN}

PHE greatest zoologist of his time, Sir E. Ray Lankester, has said that man has differed from all other inhabitants of the animal kingdom in being able to resist the pressure of circumstances which have altered and destroyed them. In all the cases of the animals which we have been considcring, these creatures have been limited by the conditions of geography; they have been killed by extremes of heat and cold; they have been subject to starvation if one kind of diet were unobtainable; and they have constantly altered in shape, structure, and appearance, according to the requirements of the new conditions in which they found themselves. But man's mind and will have enabled him to cross rivers and oceans by rafts and boats, to clothe himself against cold, to shelter himself from heat and rain, to prepare an endless variety of food by fire, and to increase and multiply as no other animal without change of form, and without submitting to the terrible axe of selection wielded by ruthless circumstance over all other living things on this globe. "Ind as he has more and more obtained this control over his surroundings, he has expanded that unconscious protective attitude towards 284 


\section{THE KINGDOM OF MAN}

his mature offspring which natural selection had already favoured and established among the mammals into a conscious and larger love for his tribe, his race, his nationality, and his kind. He has developed speech, the power of communicating, and, above all, of recording from generation to generation his thought and knowledge. He has formed communities, built cities, and set up empires; and at every step of his progress man has receded farther and farther from the ancient rule exercised by nature over the lower animals."

Whence comes this power? When and how did it arrive? That we do not know. For the early beginnings of man we can only grope among the relics of his progress which he has left for the speculation of his more intelligent descendants, in the shape of the rude implements and dwellings which he used in the childhood of the race.

From time to time actual remains of early man are found buried among the uppermost strata, and from them we can make some guesses at his age. Virtually three links have been found in the chain of human ancestry. The earliest is represented by the "Trinil Man" of Java, found by Dubois in 1890 , and named the Pithecanthropos erectus, in reference to its likeness both to man as we know him and to the great anthropoid apes, although it had a much more erect carriage than any of them. This relic, man or some other creature as it may have been, stands midway between the chimpanzee and the more typical "Neandarthal Man," the skull of which was found in a cave of the Neander Valley, near Dusseldorf, in 1856. Thirty 


\section{THE KINGDOM OF MAN}

years later the skulls of the "Spy men" of the same type as this were found in Belgium. This type lived in what we call the early Stone Age, and was a low type of meateating hunter. The next higher type, the third type of man, is that identified with what geologists and anthropologists call the "Gibraltar skull," from the place where the skull was found. But all we know of these types of man we must judge from their skulls and from the stone implements and the animals found near them. The skulls of primitive men and of modern men show a certain difference in shape. If we take two skulls, that of a man and a monkey, and draw a line from the region just over the nose to the place at the back of the skull just above where it joins the backbone, there is left above the line a great clome in the human skull, whereas in the monkey the place left above is much flatter and much shallower. Now the skull of the Pithecanthropos erectus found in Java resembles the monkey's skull in this shallowness; and the skulls of the Neandarthal and the Spy men also had shallower brain-pans than the men of to-day. They may, therefore, be either different creatures or they may merely have had smaller brains. We can only say that the creature called Man suddenly appears among the lower animals with a brain some five or six times the bulk (in proportion to his size and weight) of that of any surviring ape. Grent as is the difference, it is one of the most curious facts in the history of man's development that the bulk of his brain does not seem to have continued to increase in any very marked degree since the early Ages of Stone. 


\section{THE KINGDOM OF MAN}

What were the Stone Ages? In the long years before primitive man learned to weld iron or bronze he formed his weapons and his tools from stone and flint; and geologists and antiquarians have discovered several of these "Ages of Stone" of different periods. For example, the Stone Age which our grandfathers spoke of is now called the Neolithic Age; and in the second quarter of the last century it became gradually admitted that man had existed earlier than that and had swung hammers and chipped edges in what we now call Palæolithic times. That would put man back to the age of the Mammoth. But in the last quarter of last century a new claim arose. The Palæolithic stone weapons and tools were made 150,000 years ago, and were manufactured with great skill and even artistic feeling. Within the last ten years much rougher flint implements of peculiar types have been found in gravels which are 500 to 700 feet above the level of the existing frivers-in the drift of which Palæolithic implements were found. To these older, clumsier weapons and tools-if, indeed, implements they be-the name Eoliths was given by Mr. J. Allen Brown. These Eoliths of the south of England and of Belgium indicate a race of men of less developed skill than the makers of the Palæoliths, and carry the antiquity of man at least as far back beyond the Palæoliths as these are from the present day. So much for speculation. But are the Eoliths truly implements, or are they, as a deternined school of anthropologists assert, merely flints which fortuitously resemble the rougher variety of true Palæolith? The strongest attack made on their authenticity comes 


\section{THE KINGDOM OF MAN}

from Professor Boule and M. Laville, of the French School of Mines, who say that in the flint waste of a cement factory at Mantes they have discovered "pseudoEoliths" which are made by the action of the water of the mill, and which resemble every known variety of the so-called "Eolith." Their suggestion is that Eoliths were not made by man at all but were produced by the action of running water. To which the Eolithic anthropologists retort that Eoliths ought surely to be produced by running water now, and that some Seine-made Eoliths would be more convincing. The differences between the Mantes specimens and the "true" Eolith cannot be detected by the untrained eye; but, spite of the French sceptics, the school of believers in the genuineness of the Eolith is growing.

We need not enter further into these controversies, and we need only say that flint implements of various kinds are found all over the world, in Egypt before the Pharaohs, in Australia, in South Africa, and indeed in every continent. They are being made even to-day by aborigines in Australasia, and there is even a "flint knapping " industry which survives to-day at Brandon, in Suffolk, though these flints are not intended for use as spear-heads or arrow-heads or anything so primitive. There is little geological evidence to show the place where man first appeared; but what we know of his frame and constitution induces us to believe that somewhere in the warm climate of Southern Asia was his first habitation. From this, or from some similar tract in that quarter of the globe, there seems to have been four great migratory 


\section{THE KINGDON OF MAN}

movements. These were complicated by reverse movements, by cross migrations, and by wanderings, which we shall probably never altogether understand; and so we can only sum up briefly the chief features of them.

The greatest movement appears to have been northeastward between the great desert and mountain tract of Central Asia on the one hand, and the Pacific on the other, attended by divergences eastward to many islands (as they are now) of the Pacific. When the emigrants got too far north to wish to explore further, they spread out to east and west, forming a belt below the Arctic regions and sending a branch down the whole length of the American Continent. This movement embraced the Mongoloid races, and included the old American Indians and the Malayan races. Before the disturbing influences of man's later development, this branch had three notable centres of civilisation: the Chinese in Asia, the Mexican in North America, and the Peruvian in South America.

A second and much less numerous band of emigrants struck out to the south-east, and reaching the southern hemisphere gave rise to the Australian and New Zealand aboriginal races-all peoples who never rose very much or developed notable power.

To a third movement to the south-west is assigned the peopling of Africa south of the Saliara with the negro and similar races, which have become very numerous but never very powerful or intelligent.

The fourth movement was north-westward across or 


\section{THE KINGDOM OF MAN}

around the barriers of desert and mountain to Western Asia, Europe, and North Africa. These emigrants were the true adventurers, hardy, progressive, and energetic; and their descendants have developed into the strongest and most vigorous of the luman family. The less progressive of them remain still on the further side of the mountains of Western Asia. The three passage-ways used by the original emigrants seem to have been (1) the Red Sea Nile-Valley path, in which the dusky white and the Ethiopian races mingled; (2) the Euphrates Valley, down which the Semitic races moved; and (3) the tracts of the more northerly plateau, across which moved the ancestral Aryan races. It is also quite certain that some races moved backwards by this route and returned to India to give rise to the Brahmins, the most learned race of that country.

IVe have thus traced, so far as our limited knowledge will allow us, the geographical spread of man's dominance. But we cannot associate him with the history that in previous chapters we have roughly traced, of the development of the lower members of the animal kingdom. The qualities which have developed in Man are of such an unprecedented power and so far dominate everything else in his characteristics and surroundings that they justify the view that he forms a new departure in the gradual unfolding of this world's predestined scheme. Knowledge, Reason, Self-consciousness, IVill, are the attributes of Mnn. Ile goes on from strength to strength, and in the Divine purpose which created him may lie the possibility that in the future he may attain a fuller knowledge than any he 


\section{THE KINGDOM OF MAN}

yet possesses. The great poet of the Victorian Age wrote of Knowledge:-

Flower in the crannied wall

I pluck you out of the crannies;

I hold you there, root and all, in my hand,

Little flower-but if I could understand

What you are, root and all, and all in all,

I should know what God and man is.

The nearer approach to that understanding is the greatest and truest aim of scientific investigation.

The End 



\section{INDEX}

Adelsberg, Caverns of, 195

Exyornis, The, 252

"Age of Lakes," The, 257

Air, how it may become solid, 84

Aleutian Islands, Volcanoes of the, 97

Algæ, 103

Alluvium, 54

America in the Devonian Period, 217; in the Glacial

Period, 271

Ammonites, 210

Amueba, The, 100

Andes, Volcanoes of the, 97

Andesite, 184

Andromeda, 92

Animal Life, The first, 104

Animal Species of the Carboniferous Period, 229

Ant, White, The work of the, 44

Anthracite, 133

Apes, The first, 268

Apteryx, The, 252

Archran Era, 129, 199

Archoopteryx, The, 243

Archelon, The, 249

Arches, The strain on, 25

Aristotle and Earthquakes, 176 


\section{INDEX}

Armadillos, 275

Arrhenius, Prof., Theory of, 88

Arsinoitherium, The, 266

Assam, Earthquake in, 155

Atmosphere, has the Moon one? 123; of Mars, 126

Atmospheric pressure, 80, 101

Attraction of bodies, 102

Austen, Sir W. R., his experiment, 85

Avalanches, 69

Babylon, 45

Bacteria in Devonian Period, 217

Baikal, Lake, effects of earthquake, 140

Baltic, Ice in the, 74

Barometer, The use of the, 24

Basalt Rocks, 132

"Beds of Passage," 236

Birds of the Jurassic Period, 243

Bogoslof Islands, 162

Borings, Deep, 79

Boulder-clay deposited by glaciers, 73

Brachiosaurus, The, 241

Bralımaputra, The delta of the, 60

Britain in the Silurian Period, 211 ; in the Mesozoic Period, 231

British Isles, Ice in the, 75

Brontosaurus, The, 240

Cainozoic Period, The, 199

Calabria, Earthquake in, 149

Calamites, 222 


\section{INDEX}

Calumet and Hecla Mine, Temperature of, 82

Cambrian Hills, The, 200

Cambrian Period, 117; life in the, 202; surface of the globe in, 205

Carbonate of Lime, 40, 48

Carbonic Acid, The action of, 47

Carboniferous or Mountain Limestone, 218

Carboniferous Period, The atmosphere of, 219; insects, mollusca, vegetation, 220; fish, 224 ; strata, 226 ; animal species, 229

Carboniferous System, Extent of the, 227

Cariama, The, or Screamer, 251

Carinthia, Earthquake in, 141

Carrara marble, 134

Cephalopod types, 207

Ceratosaurus, The, 240

Chalk, what it is, 21, 248

Chelonians, The, 233

Climate, The changes of, 33

Coal, 219

Coccosteus, The, 215

Collision of planets, A, 93

Constructive work of earthquakes, 181

Coral Islands, 66

Coral reefs, 63

Coral reefs in the Silurian Age, 210

Coryphodon, The, 259

Cracks in the crust of the Earth, 97

Crater Lakes, 109

Crinoids, The, 210

Crustacea, 131, 202 


\section{INDEX}

Crust of the Earth, The study of the, 198

Cyclones, 42

Dead Sea, The, 58

Deltas of rivers, 20

Deposits, how they are made, 20, 45

Depths of the sea, 189

Deronian Period, 212; fishes of the, 216; vegetation, 216; insects, 216; Europe and America, 217

Diamonds, how they are produced, 132

Dinoceras, 'The, 266

Dinosaurus, The, 240

Diplodocus, The, 241

Dolichosurers, 249

Dover, The chalk cliffs of, 21

Dredging, 'The necessity for, 20

Dryopithecus, 'The, 268

Dryptosaurus, 'The, 253

Dwina, Fossils in the banks of the, 232

Dykes, 105

Earth, The, not so solid as it looks, 23 ; its resemblance to a golf ball, 25 ; its uneven surface, 31

Earth, Weighing the, 88

Earthquake districts, 171

Earthquake, The sensation of an, 137 ; the cause of an, 166 , 170

Earthquake waves, 174

Earthquakes, 23; San Francisco, 140; New Madrid, 140;

Lake Baikal, 140 ; Iceland, 1 1 ; Carinthia, 111 ; Japan, 141 ; Occan, 143 ; Lisbon, 14 ; Sicily, 149; Chili, 150 ; 


\section{INDEX}

Assam, 156 ; Jamaica, 157 ; the Mississippi, 158 ; Sonora, 160 ; Yakutat Bay, 160

Earthquakes, "Great" and "Small," 172 ; their constructive and destructive work, 181

Earthworm, The work of the, 44

Edentata, The, 275

"Egg-stone," 236

Eifel District, Crater Lakes of the, 109

Elasmotherium, The, 265

Elephant, The, 260

Elephas Imperator, 280

Emu, The, 260

Encroachment of the sea on the shores of the British Isles, 17

Eocene Period, The, 257

Eohippus, The, 263

Eoliths, 287

Era of the First Plants, 103

Erosion, Sea, 19

"Erratic" blocks deposited by glaciers, 72

Eulalie, Lake, effect of earthquake on, 142

Europe in the Devonian Period, 217

Evolution, 115

Excavations and what they reveal, 34

"Faults," 167

Fish in the carboniferous period, 224

Flint, 248

Flint implements, 288

Florida, Encroachment of the sea on the coast of, $1 \mathrm{~s}$

Flying Reptiles, 242 


\section{INDEX}

"Foliated" rocks, 200

Foraminifera, 247

Forests covered by the sea, 19

Fossils, 131; in the banks of the Dwina, 232

Fossil records, 56

Fumaroles, 185

Ganges, The Delta of the, 20

Gases, How metals may be converted into, 84

"General Metamorphism," 133

Geologist, The work of the, 37

Geology, 37

Germany, Sand-dunes in, 46 ; Ice in, 74

Geysers, 141

Giant's Causeway, 132

"Gibraltar Skull," The, 286

Gingko 'Tree, 228

Glacial Period, The, theories concerning, 272

Glaciers, 69, 270

Globigerina bulloides, 247

Glyptodon, The, 275

Gneiss, 200

Grand Cañon of the Colorado, 54

Graphite, 133

Great Barrier Reef, 66

Great Salt Lake, 57

Hadrosaurus, The, 253

Harwich, Encroachment of the sea at, 17

Hawaii, Lava eruptions in, 105, 187

Heat and Cold, 68 


\section{INDEX}

Heligoland, Encroachment of the sea on, 18

Hesperornis, The, 249

Horse, The, 259, 264

Hurricanes, 43

Ice in Scandinavia, Scotland, Germany, 74, 270

Iceland, Eruptions in, 106 ; Earthquakes in, 141, 154

Ichthyornis, The, 250

Ichthyosaurs, The, 234, 239

Igneous rocks, 104

Iguanodon, The, 245

Inostransevia, The, 233

Insect life in the Ordovician Period, 206 ; in the Devonian

Period, 216

"Inter-glacial epochs," 273

Interior of the Earth, Theories concerning the, 87

Isle of Wight, Encroachment of the sea in, 17

Jamaica, Earthquake in, 157

Japan, Earthquake in, 141, 153

Jupiter, 91 ; as an abode of life, 119

Jupiter Serapis, The Temple of, 181

Jurassic Period, Reptiles of the, 237

Kelvin, Lord, Theory of, 87 ; concerning Life, 113

Kern, River, Effect of earthquake on, 141

Kingston, Jamaica, Earthquake, at, 176

Kipling, Rudyard, 62

Kimi, The, 252

Krakatoa, The eruption of, 45 


\section{INDEX}

Lago di Tolfilo, 152

Lakes, Deposits in, 56

Lakes produced by earthquakes, 152, 159

Land and Water, The distribution of, 31

Lariosaurus, The, 234

Laurentian Rocks, 133, 201

Lava eruptions, 105 ; in N. America, 106 ; plains, 107

Layers of strata which show the history of a place, 37

Leakage of the sea bottom, 190

Leonids, Lyrids, or Perseids, 99

Lias formation, The, 235, 237

Life, The simplest forms of, 111 ; theories concerning its origin, 113; early forms, 114; in the Cambrian Period, 202; in the Silurian Period, 203; in the Ordovician Period, 204

Lisbon, Earthquake at, 148

Llama, The, 273

London, What excavations have revealed concerning the site of, 35

Luray, Caverns of, 196

Lycopods, 222

Lyginodendrons, 223

Mammals, The development of, 234, 258

Mammoth, The, 279

Mammoth Cave of Kentucky, 196

Man, 284

Marble, how it is produced, 133

Marl in lakes, 57

Mars, 91 ; as an abode of life, 119 ; atmosphere, 126

Marsupials, 237 


\section{INDEX}

Martinique, Devastation of, by volcano, 186

Mastodon, The, 260

Megatherium, The, 275

Mercury as an abode of life, 118

Meritherium, The, 261

Mesozoic Period, The, 199, 231

Metals may be converted into gases, 84

Meteorites, 96

Microbes and Bacteria, 111

Microlestes, 237

Migrations of the human race, 290

Miller, Hugh, 213

Millstone Grit, 218

Miocene Period, The, 257

Mississippi, The Delta of the, 20; sediment deposited, 51 ; earthquake in region of, 159

Moa, The, 252, 260

Monsoons, 42

Moon, The, 90 ; its birth, 100, 120; volcanoes in, 106 ; as an abode of life, 119; weight, 120; temperature, 124

Moraines, 70

Moraine-stuff, 70

Mountain formation, 167

Mud-banks, how they are made, 19

Mussels, 210

Mylodon, The, 276

Myths concerning earthquakes, 177

Noosaurus, The, 230

Neandarthai man, 285 


\section{INDEX}

Nebulæ, 92

Negroes, Nature's reason for the dark pigmentation of, 116

Neolithic Age, The, 287

Neptune, 119

New Chum Mine, Temperature of, 83

New Madrid, Earthquake at, 140

Niagara Falls, The work of the, 52

Nile, The Delta of the, 20

Nineveh, 45

North America, Ice in, 76

North Garden Gully Mine, Temperature of, 83

North Sea, The, how it was formed, 19

North Sea, Ice in the, 75

Ocean deposits, 61 ; life, 114

Oceanic Era, The, 101

Old Red Sandstone, 212

Oolite, 66, 238

Ordovician Period, Life in the, 201; surface of the earth in the, 206; insect life in the, 206; fish in the, 207 ; the Trilobite, 207

Ordovician rocks, 202

Oreopithecus, The, 268

Organisms, Multicellular and Unicellular, 111

Orion, 92

Ostracoderm group, The, 215

Ostrich, The, 260

Oxygen, The action of, 47

Palxolithic Age, The, 287

Palcomastodon, The, 261 


\section{INDEX}

Palæozoic Period, The, 199

Palæozoic Alps, The, 219

Pareiasaurus, The, 232

Parsons, Hon. Charles, on the difficulties of deep boring, 79 "Pea-grit," 238

Peak Cavern in Derbyshire, 195

Pearl-oyster, The, 210

Peat-water, The action of, 48

Pelée, Mount, 86, 108; the obelisk, 184

Permian or Dyas formation, 227

Peroxide of Iron, 40

Perseids, 99

Pharorachus, The, 251

Pithecanthropos erectus, 285

Planetismals or Meteorites, 99

Plant life in the Silurian Period, 210

Plants, Era of the first, 103

Pleiades, The, 91

Pleistocene Period, The, 269

Plesiosaurus, The, 234, 239

Pliny on the upheaval of land, 192

Pliocene Period, The, 257

Po, Sediment deposited by the River, 20

Polyps, Coral, 65

"Pot-holes" in Yorkshire, 195

Pre-Cambrian, 201

Pressure, of air, 80; of the ocean, 190

Pressure and weight of rocks, 85 ; astounding effects of, 134

Pribylof Islands, 164

Proboscideans, The, 273

Proterosoic cra, The 130 


\section{INDEX}

Pteraspes, The, 215

Pterichthyds, The, 215

Pterodactyls, 242

Pterosaurs, The, 255

Quartzite, 200

Quaternary Period, The, 199

Quebec, Collapse of the bridge of, 25

Rag-stone, 238

Rain, The influence of, 47

Rainfall on the British Isles, 128

Raised Beaches, 151

Red clay deposit in the ocean, 61

Red Sandstone Formation, 212

Reptiles and Amphibians of the Triassic Period, 232; of the Jurassic Period, 237

Reptiles in the Carboniferous l'eriod, 229

Rhinoceros, The, 265

Rhizopods, The, 224

Rhæric beds, 237

Rivers and Streams in the Silurian Age, 209

River Terraces, 55

Rivers, Work done by, 20; records left by, 50

Rocks, how they are made, 79 ; igneous and sedimentary, 104, 129 ; "foliated," 200

Rocks, Pressure and weight of, 85

Roestone, 238

Romney Marsh, 60

Rorqual, The, 275

Royal Commission on Sea Erosion, 19

Sabre-toothed Cat, The, 273 


\section{INDEX}

Saharan desert, The, 22

St. Pierre, Destruction of, by volcano, 186

Salt Lakes, 57

Sambon, Dr., 116

Samotherium, The, 266

San Francisco, Earthquake at, 140, 161

San Gabriel River, effect of earthquake on, 141

Sand-banks and mud-banks, how they are made, 20

Sand-dunes, how they are made, 45

Saturn as an abode of life, 119

Scaly Saurians, 248

Scandinavia, Ice in, 74

Schist, 200

Scotland, Ice in, 74

Sea, depths of the, 189 ; in the Silurian Age, 210

Sea, The, encroachment on land, 17; Isle of Wight, 17 ;

British Isles, 17; Florida, 18 ; Heligoland, 18 ; Erosion,

19 ; its work, 19

Seaquakes, 143 ; Chilian coast, 144 ; the Florence Nightingale,

145 ; sensation of, 145 ; origin of, 147

Sea-water, The action of, 65

Sediment deposited by rivers, 20, 51

Sedimentary rocks, 104, 129

See, Dr. J. J., his theory concerning the interior of the earth, 88

Seismology, 23 ; in Japan, 153

Seismometers, 24, 153

Shape of the Earth, The, 31

Sharks, 216

Shingle, how it accumulated, 60

Shells found on dry land, 19 ; forests covered by, 19 


\section{INDEX}

Shells in lakes, Deposit of, 57 ; in the ocean, 63

Shetland Islands, Action of the sea on the, 59

Sigillarias, 222

Silchester, 45

Silica, 40

Silurian Period, Scorpions and insects in the, 203; surface of the earth in the, 208; rivers and streams, 209; coral reefs, 210; fish, 210; plant life, 210 ; Britain, 211

Silurian rocks, 202

Sivatherium, The, 266

Snail-shells in lakes, 57

Snakes, First appearance of, 255

Snow and Ice Age, 68

Sonora, Earthquake at, 160

Sperm Whale, The, 274

Sphenodon, The, 230

"Spy men," 286

Stars, The, 91

Steam a cause of earthquakes

Stegosaurus, The, 242

Stone Age, The, 287

Stones smoothed by water, 55

Strata, The earth's, $7 \mathrm{~S}$

Strokkur geyser in Iceland, 141

Submarine voleanoes, 187

Subterranean caves, how caused, 195

Sun, The, 90 ; as an abode of life, 118

Tapir, The, 273

Temperature of borings, The, 83; of the Moon, 124; of Mars, 126 


\section{INDEX}

Temperature, Changes of, 33

Terminal moraines, 76

Tertiary Period, The, 257

Tetrabelodon Mastodon, The, 260

Thames, Sediment deposited by the, 21

Tides, 87, 102

Titanotherium, The, 265

Tornadoes, 43

Torrents, The action of, 52

Torridonian Sandstones, 130

Trade Winds, 42

Triassic Period, The, 231

Triceratops, The, 253

Trilobite, The, 204; in the Ordovician Period, 207

"Trinil Man," The, 285

Typhoons, 43

Ultima Speranza Cave, The, 276

Upheaval of land, 151; 181

Uranus, 119

Valais Mountains glacier, 72

Valparaiso, Earthquake at, 160

Vegetation on the Moon, 124; of the Devonian Period,

216 ; of the Carboniferous Period, 220; of the Jurassic

Period, 245

Venus as an abode of life, 118

Vertebrates, Evolution of the, 225

Volcanoes of the Andes, 97 ; in the Moon, 106

Water, The action of, $4 \tau$; its power, 51

Water, The formation of, 109 


\section{INDEX}

Trateree, The, carried inland by a vast wave, 114

Waterspouts : how they are caused, 44

Waves caused by earthquakes, 143, 144, 145; the Chilian coast, 144; Hakodate, 144; the ship Wateree, 144; Arica, 144 ; Samoa, 145; N. Zealand, 145 ; Japan, 145 ; speed of, 145 ; Lisbon, 148

Weather, The influence of the, 40

Whales, 267

Weighing the earth, 88

Wind-stakes for stopping sand, 46

Wind, The work of the, 40 



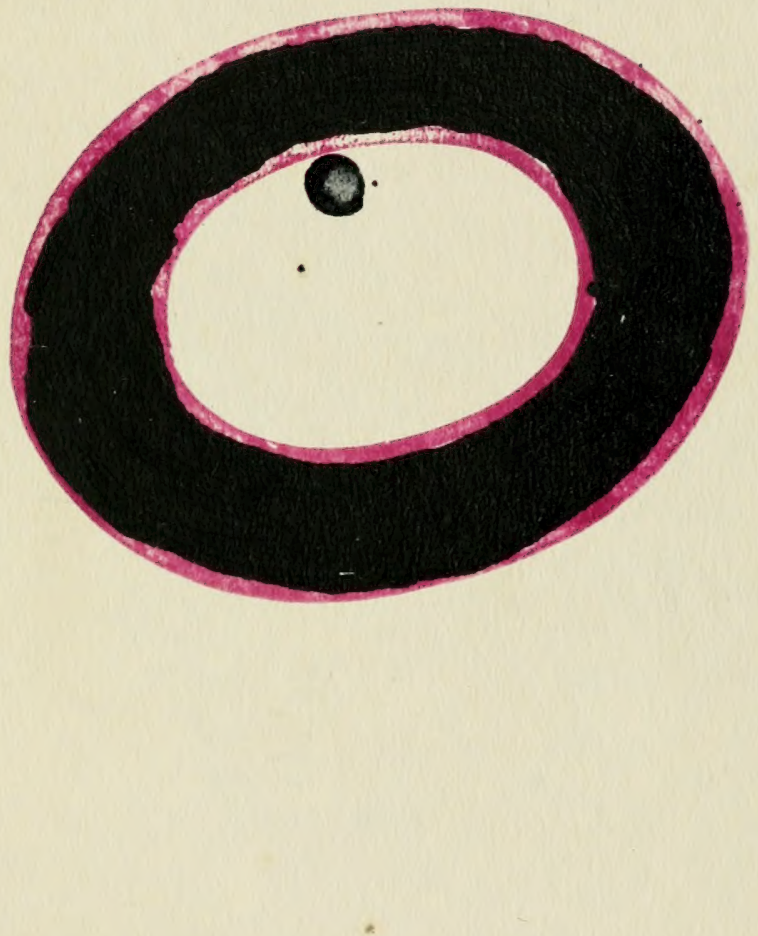


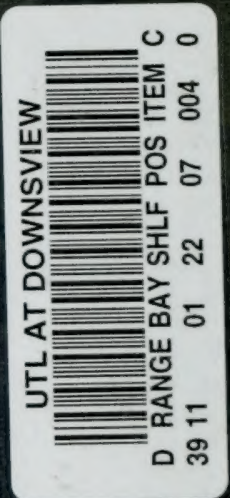

